\section{José Marques Carriço}

Legislação urbanística e segregação espacial nos municípios centrais da

Região Metropolitana da Baixada Santista
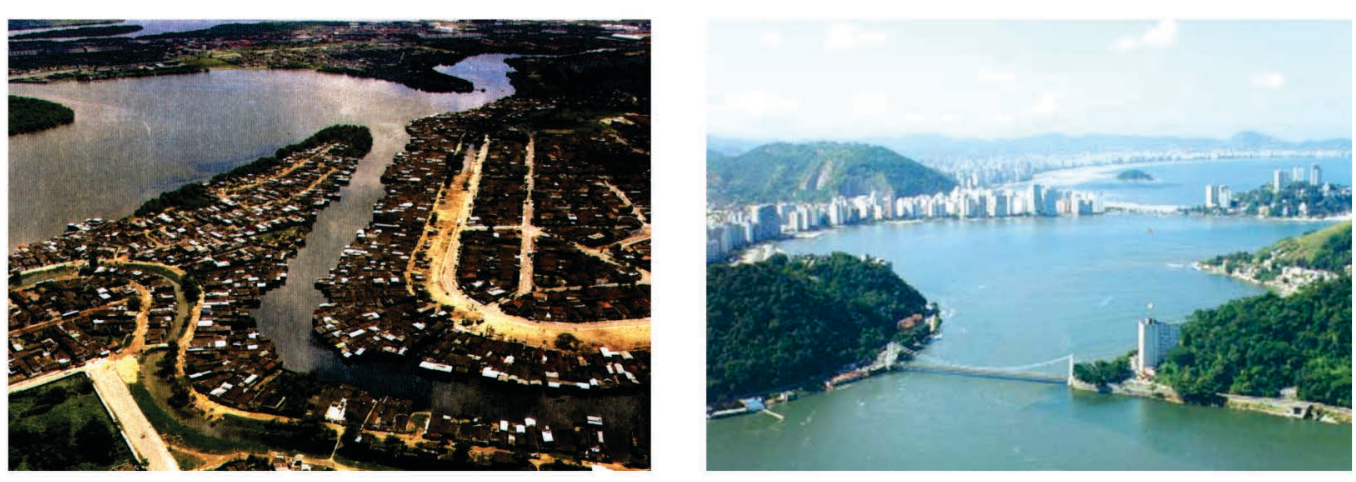

Faculdade de Arquitetura e Urbanismo Universidade de São Paulo

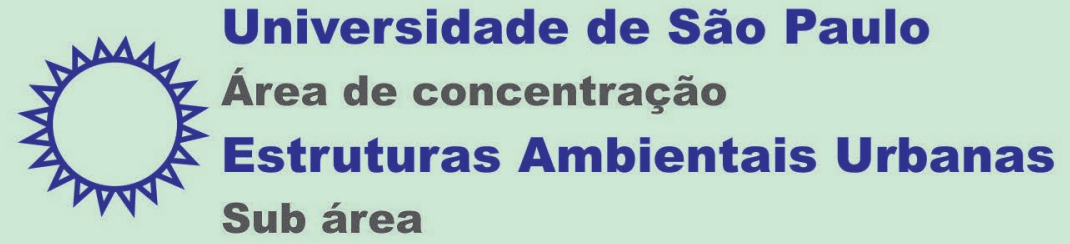

Planejamento Urbano e Regional
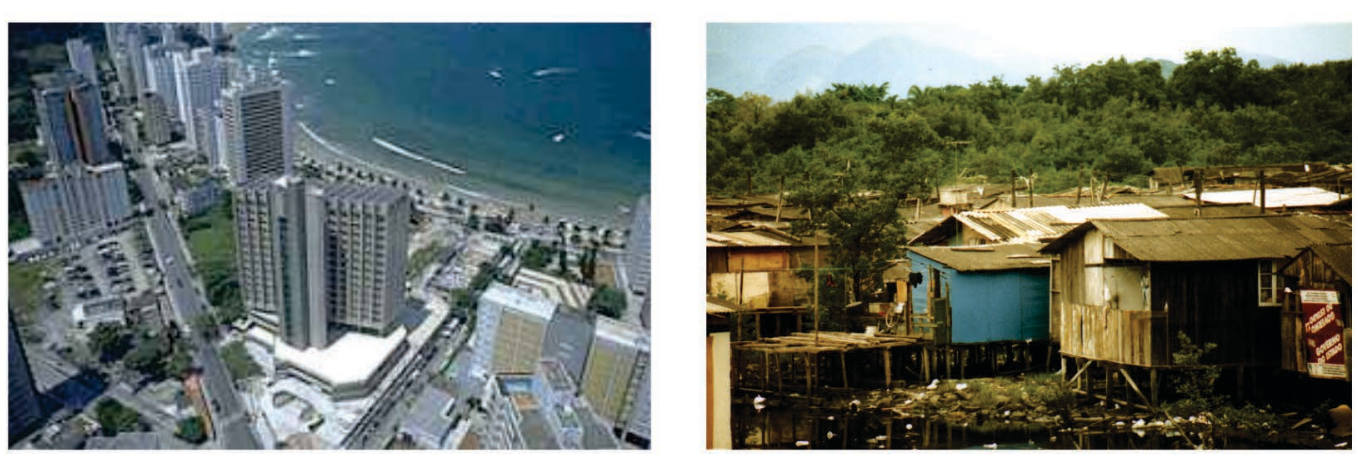
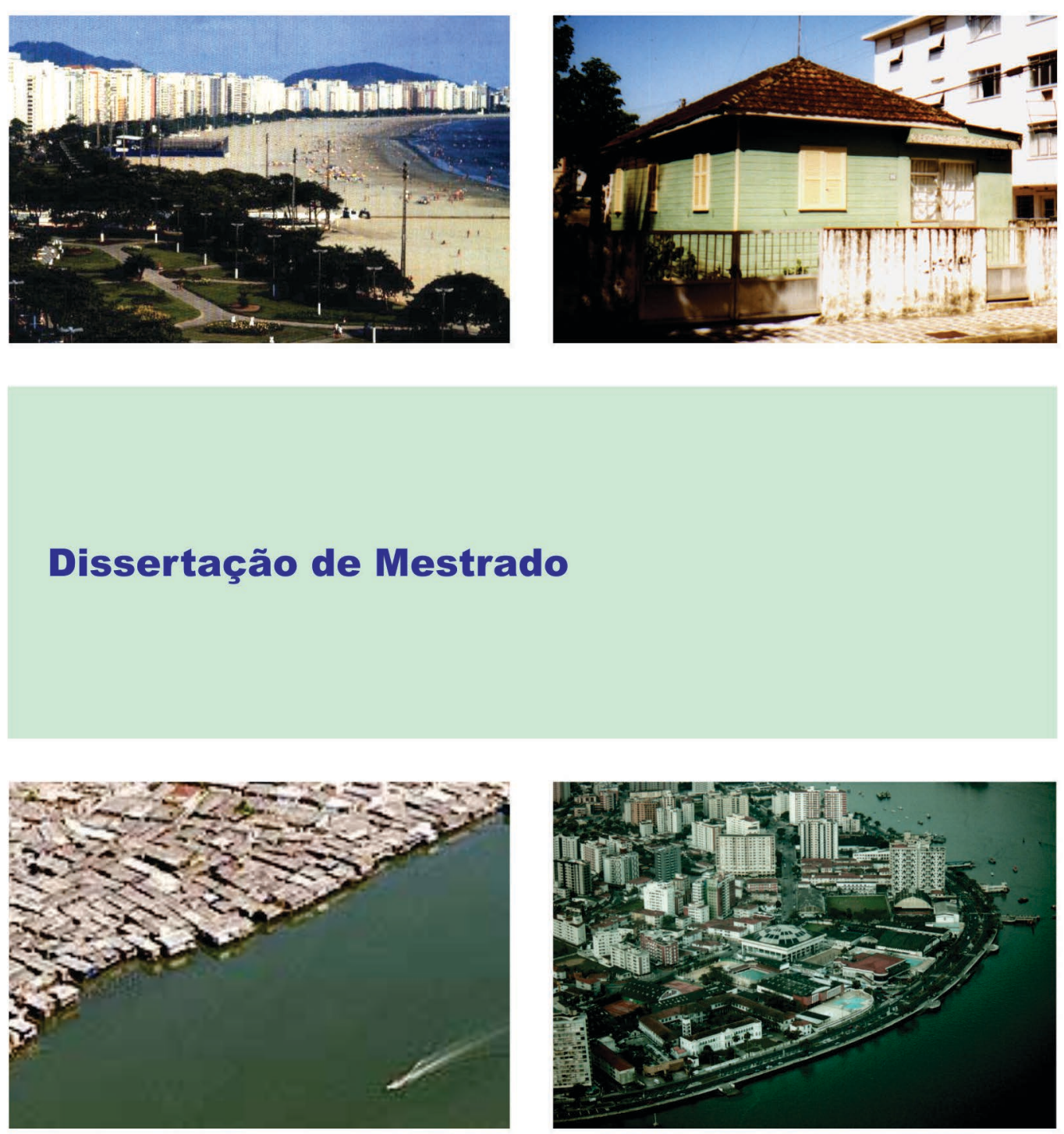

Orientadora

Professora Doutora Sueli T. Ramos Schiffer

São Paulo, 2002. 
José Marques Carriço

Legislação urbanística e segregação espacial nos municípios centrais da Região Metropolitana da Baixada Santista

Dissertação de mestrado

\section{sents \\ Faculdade de Arquitetura e Urbanismo Universidade de São Paulo}

Área de Concentração
Estruturas Ambientais Urbanas
Sub área
Planejamento Urbano e Regional

Orientadora

Professora Doutora Sueli T. Ramos Schiffer

São Paulo, 2002. 


\section{Sumário}

1. Introdução ..............u.

2. Caracterização da RMBS

2.1. Breve histórico da ocupação dos municípios centrais da RMBS

2.2. Caracterização socioeconômica da RMBS

2.3. As condições habitacionais na RMBS

2.3.1. A Pesquisa de Condições de Vida - PCV - da Fundação SEADE

2.3.1.1. PCV-98 Condições Habitacionais

2.3.1.1.1. Tipo de Edificação

2.3.1.1.2. Número de cômodos.

2.3.1.1.3. Grau de Salubridade da Moradia

2.3.1.1.4. Apropriação da Moradia

2.3.1.1.5. Forma de Obtenção das Moradias Próprias

2.3.1.1.6. Infra-Estrutura Urbana

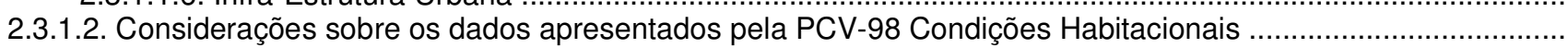
2.3.2. O déficit habitacional da RMBS segundo os municípios

3. A segregação espacial nos municípios centrais da RMBS

3.1. Evolução da distribuição das populações de baixa renda no território dos municípios centrais da RMBS

3.1.1. Período do Café

3.1.2. Período Desenvolvimentista

3.2. As formas de acesso e tipologias habitacionais das classes de baixa renda da RMBS

3.3. Distribuição espacial atual das áreas de habitação subnormal nos municípios centrais da RMBS

3.4. Considerações sobre o processo de segregação espacial nos municípios centrais da RMBS

4. A questão da terra no Brasil e a evolução da regulação urbanística dos municípios centrais da RMBS

4.1. A evolução da regulação urbanística em Santos

4.1.1. A Legislação Urbanística em Santos em meados do século XIX

4.1.2. A legislação urbanística de Santos no Período do Café

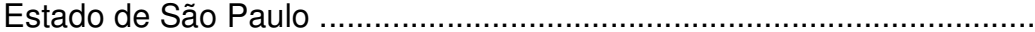

4.1.2.2. A legislação do início do século XX até o Código de Construções de 1922

4.1.3. A legislação urbanística em Santos no período desenvolvimentista

4.1.3.1. A Legislação urbanística até o segundo pós-guerra

4.1.3.2. A legislação urbanística até o golpe militar

4.1.3.3. A legislação urbanística do milagre econômico

.

2. A regulação urbanística nos demais municípios centrais da RMBS

4.2.1. A regulação urbanística em São Vicente

4.2.1.1. Análise da legislação urbanística de São Vicente

4.2.2. A regulação urbanística em Cubatão

4.2.2.1. Análise da legislação urbanística de Cubatão 
4.2.3. A regulação urbanística em Guarujá

5. A evolução do valor imobiliário em Santos

5.1. Valor imobiliário - o caso de Santos

5.2. Regulação urbanística e mercado imobiliário

5.3. Estudo comparativo dos valores unitários em distintas áreas de Santos

5.3.1. Análise da evolução do valor imobiliário nas décadas de 60 e 80

6. Conclusão

Referências bibliográficas

Anexo 1 - Legislação consultada

Anexo 2 - Cartografia consultada
Anexo 3 - Entrevistas realizadas 


\section{Resumo}

Esta dissertação visou estudar o processo de segregação espacial da população de baixa renda nos municípios centrais da Região Metropolitana da Baixada Santista, situada no litoral do Estado de São Paulo. O período de estudo é o que se inicia a partir da implantação do Porto de Santos, no último quartel do século XIX, até o final da década de 1970.

Da mesma forma que ocorreu nas demais metrópoles brasileiras, parcela significativa da população da Baixada Santista vive em condições precárias, em áreas distantes dos locais que concentram a maior oferta de emprego e renda. Em relação aos demais aglomerados urbanos do Estado de São Paulo, as péssimas condições de habitabilidade na Região Metropolitana da Baixada Santista - RMBS - são comparáveis, em precariedade, apenas às da Região Metropolitana de São Paulo.

As áreas onde a população de baixa renda habita são desprovidas do nível mínimo aceitável de oferta de infra-estrutura, serviços e equipamentos urbanos. Em grande parte, são locais ambientalmente frágeis como encostas sujeitas a escorregamentos, habitações insalubres em áreas urbanas degradadas, várzeas inundáveis ou mangues. Na quase totalidade, o acesso à moradia nesses locais se dá por meio do mercado informal, com situação fundiária irregular.

A partir da análise da legislação urbanística dos municípios selecionados, quais sejam Santos, São Vicente, Cubatão e Guarujá, foi possível identificar uma série de elementos que, ao longo do tempo, de forma direta ou indireta, contribuíram para reforçar a situação de segregação espacial, geralmente por meio de mecanismos que dificultaram ou impediram o acesso às melhores localizações pelas classes de baixa renda.

Analisando-se as relações entre segregação, acessibilidade e regulação urbanística, procurou-se contribuir para a compreensão da história sob a ótica dos excluídos, que formam a parcela da população derrotada na luta pela obtenção de localizações habitacionais adequadas na RMBS. 


\section{Abstract}

This thesis aims at studying the historical process of spatial segregation of the low-income population in the major cities of the Baixada Santista metropolitan region, which is situated in the seaside of São Paulo state. The period studied started in the last quarter of the $19^{\text {th }}$ century with the construction of the port of Santos until the end of the 1970s.

Similar to what have occurred in other Brazilian metropolitan regions, a significant part of the inhabitants of the Baixada Santista lives in precarious conditions, located far away from job and income opportunities. Confronted to other urban conurbations in the State of São Paulo, the terrible living conditions in this region are similar only to the São Paulo metropolitan region.

The housing areas occupied by the low-income population are deprived of the minimum acceptable conditions of public infrastructure, services and urban equipments. Great part of these areas is also environmentally fragile and unhealthy, since they consist mainly of slopes, wetlands and mangroves. The access to dwellings in these areas is through an informal market, with irregular land tenure.

The assessment of the urban legislation of the selected cities studied, namely Santos, São Vicente, Cubatão e Guarujá, propitiated as a main outcome the identification of the diverse elements that have contributed over time, in different ways, to strengthen the process of urban segregation, through several mechanisms that hindered or prevented the access of the lowincome class to better housing locations.

The development of a deeper analyze of the relations among spatial segregation, low-income housing access and urban regulation, has contributed to a better understanding of the history, from the excluded population's standpoint, which is actually the looser in the fight for better housing locations in the Baixada Santista metropolitan region. 


\section{Agradecimentos}

À professora Sueli T. Ramos Schiffer, que desde o início demonstrou grande interesse por este projeto, agradeço a orientação segura, paciente e estimulante.

A idéia de aprofundar a questão da segregação espacial na Baixada Santista nasceu em uma das inúmeras conversas com a amiga Sania Cristina Dias Baptista a quem agradeço, não somente pelo incentivo à realização deste trabalho, mas por ser a grande responsável pelo meu desenvolvimento profissional na área de planejamento urbano.

Por sugestão de Sania, procurei o professor Phillip Gun, que, por sua vez, apresentou-me à professora Sueli. Desta forma, externo meus sinceros agradecimentos ao professor Phillip pela oportunidade que me proporcionou.

A realização desta pesquisa só foi possível graças à equipe com quem trabalho, coordenada com sabedoria e fraternidade por Cassandra Maroni Nunes, a quem agradeço sua compreensão e incentivo constantes. Agradeço também aos seus membros: Carla Gonzaga do Nascimento, Ednaldo França Evangelista, Luciana Gonzaga Bornhausen, Nadir de Souza Brito, Maria de Fátima de Andrade, Marizete Fernandes Bandini, Margarida Souza Teles, Sandra Perruci e em especial a Fernando Rocha Nogueira e Siomara Gonzalez Gomes, pela valiosa ajuda em várias fases do trabalho.

Agradeço ainda aos técnicos dos órgãos públicos e privados que colaboraram com esta pesquisa cedendo material e prestando informações valiosíssimas. Dentre estes destaco Adriana Bispo de Araújo, Ana Maria Sala Minucci Martins, Augusto Muniz Campos, Carlos Alberto Soares de Souza, Daniela Marchiori Faria, Fábio Eduardo Serrano, Fernando Guilherme Martins, Fernando Teixeira da Silva, Luiz Fernando de Almeida, Marco Antônio Vilella dos Santos, Maria Aparecida Campos Carneiro, Marilú Lopes Santos e principalmente Luiz Antonio de Paula Nunes, que desde o princípio foi um grande incentivador desta empreitada.

Agradeço ao amigo Enzo Benvenuto Gambini, que me ensinou a real importância do serviço público e contemplou-me com seu acervo particular, no qual pude encontrar documentação de valor inestimável, sem a qual este trabalho não teria a mesma qualidade.

Manifesto meu reconhecimento à equipe da Fundação Arquivo e Memória de Santos, na pessoa da historiadora Rita Márcia Martins Cerqueira, cujo valioso acervo foi fundamental para a elaboração desta dissertação.

Com carinho especial quero agradecer à minha maior incentivadora e colaboradora, com quem aprendi a admirar os caminhos da pesquisa e da ciência, minha esposa e companheira Kátia, que me apoiou durante toda esta caminhada e também à nossa filha Bárbara, que foi constante fonte de inspiração deste trabalho. 
Legislação urbanística e segregação espacial nos municípios centrais da Região Metropolitana da Baixada Santista

Este trabalho é dedicado à memória de David Capistrano da Costa Filho, médico, sanitarista e prefeito de Santos de 1993 a 1996, e a todos aqueles que como David acreditam na possibilidade de transformar a sociedade, lutando pela redução das desigualdades. 
Guayaó,

da maresia e do cheiro de café torrado,

do apito do navio e do balanço da catraia, do mangue e do morro,

das muralhas da serra e da praia, meu desejo é decifrá-la.

José Marques Carriço

Santos, 31 de janeiro de 2002. 
Legislação urbanística e segregação espacial nos municípios centrais da Região Metropolitana da Baixada Santista

1. Introdução 
Legislação urbanística e segregação espacial nos municípios centrais da Região Metropolitana da Baixada Santista 
"Tratava-se de afastar dos olhos aqueles diferentes com quem, inevitavelmente, dadas as condições de produção e reprodução do capitalismo, este espaço urbano tinha que ser compartilhado"

LANNA (1996: 4).

Este trabalho teve como objetivo investigar as relações entre a exclusão espacial, legislação urbanística e valorização imobiliária nos municípios centrais da Região Metropolitana da Baixada Santista - RMBS - no litoral do Estado de São Paulo, Brasil.

No desenvolvimento da pesquisa procurou-se identificar as origens e elementos determinantes do grave quadro de segregação social presente no território da Baixada Santista, sobretudo em seus municípios centrais, quais sejam Santos, São Vicente, Cubatão e Guarujá.

Assim, no Capítulo 2 elaborou-se a caracterização socioeconômica da Região Metropolitana da Baixada Santista, especialmente dos municípios centrais, por meio da apresentação de breve histórico do processo de sua ocupação, bem como de sua evolução demográfica e atividades econômicas.

No mesmo capítulo avaliou-se as condições habitacionais da população destes municípios, com ênfase para o grupo populacional de menor rendimento, utilizando-se para tanto de dados das prefeituras locais e da Fundação Sistema Estadual de Análise de Dados - SEADE, que realizou, em 1998, pesquisa sobre as condições de vida nas principais regiões do interior do Estado de São Paulo.
A seguir elaborou-se um painel atualizado da segregação espacial das habitações da população de baixa renda nos municípios centrais, discutindo-se sobretudo as principais tipologias habitacionais e formas de acesso à moradia desta população, apresentado no Capítulo 3.

No Capítulo 4, a partir da análise da questão da posse da terra no Brasil, procedeu-se ao estudo da evolução da regulação urbanística nos municípios selecionados, pesquisando-se as respectivas legislações urbanísticas. $O$ período analisado estende-se desde a implantação do Porto de Santos, no último quartel do século XIX, até o final da década de 1970.

Neste estudo procurou-se identificar os elementos que provavelmente contribuíram para reforçar a segregação espacial, geralmente por meio de mecanismos que tenham dificultado, ou impedido, o acesso às localizações mais privilegiadas pelas classes de baixa renda.

No Capítulo 5 analisou-se as possíveis relações entre a evolução da regulação urbanística e a alteração do valor imobiliário em determinadas áreas dos municípios estudados, especialmente as ocupadas predominantemente pelas populações de alta e baixa renda.

Este conjunto de levantamentos e avaliações permitiu clarificar a gênese da segregação espacial na Baixada Santista, descartando-se definitivamente fatores que, erroneamente, são apontados como causadores desta segregação, conforme detalhado no capítulo conclusivo. 
Legislação urbanística e segregação espacial nos municípios centrais da Região Metropolitana da Baixada Santista 
Legislação urbanística e segregação espacial nos municípios centrais da Região Metropolitana da Baixada Santista

2. Caracterização da RMBS 
Legislação urbanística e segregação espacial nos municípios centrais da Região Metropolitana da Baixada Santista 


\subsection{Breve histórico da ocupação dos municípios centrais da RMBS}

A Região Metropolitana da Baixada Santista - RMBS, situada no litoral central do Estado de São Paulo, foi uma das primeiras regiões do país a ser colonizada pelos portugueses, já no princípio do século XVI. Desde então, a Baixada guarda um vínculo muito estreito com o planalto paulista, em especial com as cidades da Região Metropolitana de São Paulo - RMSP, sendo impossível desvincular o processo de desenvolvimento econômico de ambas.

A colonização inicial deu-se pelo sistema de capitanias hereditárias, sendo a Capitania de São Vicente, criada pelo nobre português Martim Afonso de Souza, no século XVI, a primeira forma de organização administrativa da região. Neste primeiro século de colonização foram fundadas, pelos portugueses as vilas de São Vicente, em 1532; Santos, em 1545; São Paulo, em 1554; Itanhaém, em 1561; e Cananéia, em 1600. Portanto, podemos afirmar que a colonização iniciou-se pelo litoral, sendo a região onde hoje se encontra a Baixada Santista, a primeira, no Estado, a contar com uma rede de vilas.

Nos primeiros séculos da colonização, a atividade econômica da região baseou-se na agricultura, sobretudo na exploração da cana de açúcar e na mineração. No entanto, essa atividade objetivava o fornecimento de mercadorias e riquezas à corte portuguesa. Assim, desde que fundada, na porção posterior da llha de São Vicente, a Vila de Santos teve papel fundamental nesse comércio, pelo fato de abrigar um atracadouro em condições mais seguras que o atracadouro construído, inicialmente, em São
Vicente. Assim, desde a segunda metade do século XVI, Santos passou a ser o principal porto da Capitania.

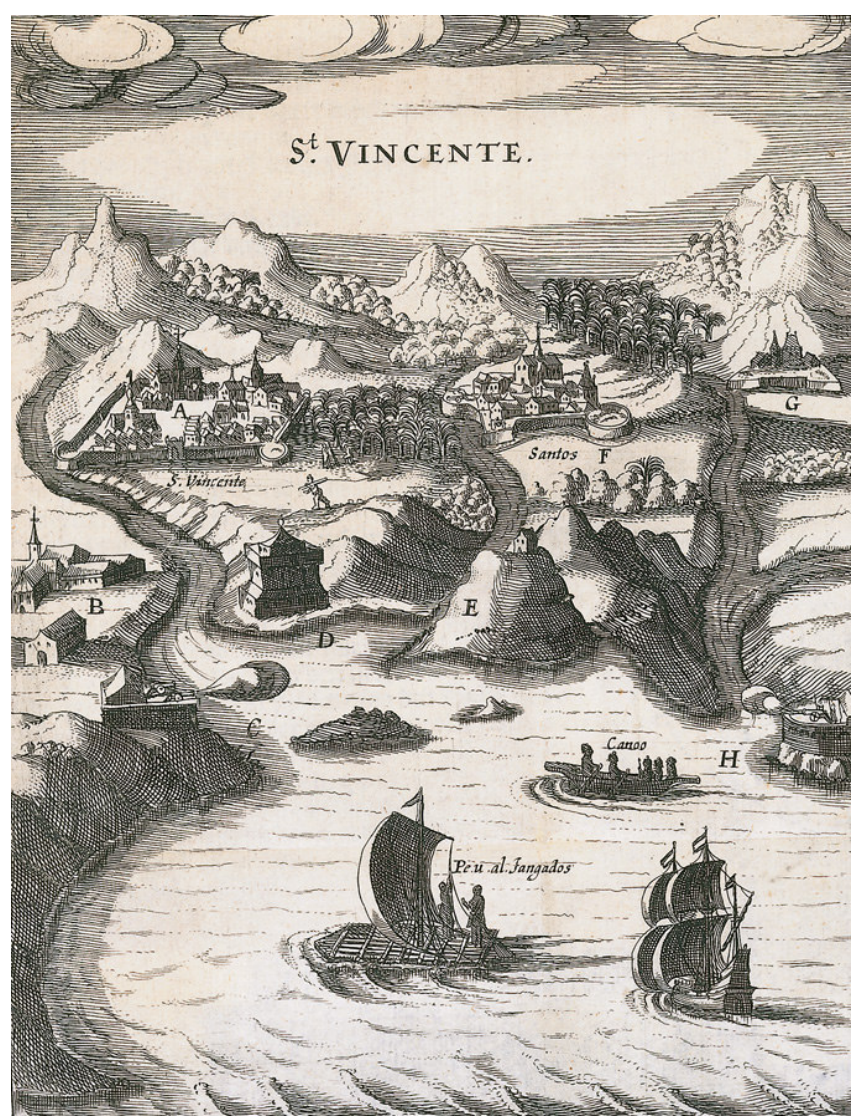

Figura 1 - Ilustração St. Vincente, representando a Baía de Santos, com a Ilha de São Vicente ao fundo, no século XVI. Autor não identificado. Fonte: Nestor Goulart Reis Filho - reproduzida do Livro de viagem ao Reino Brasileiro - Koninklijke bibliotheek, Haia - CD ROM Imagens de vilas e cidades do Brasil Colonial, 2000. 


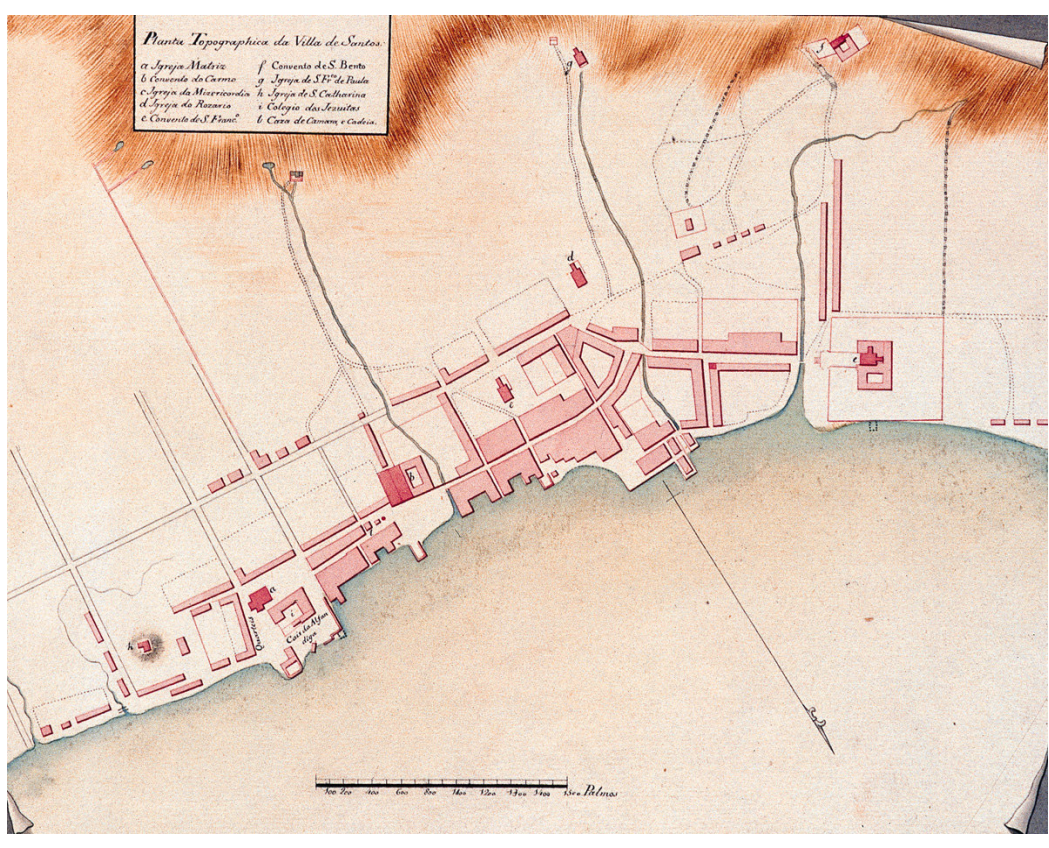

Figura 2 - Planta Topográfica da Villa de Santos, em 1815. A vila ocupava apenas a área onde hoje se localiza o centro da cidade. Autor: João da Costa Ferreira. Fonte: Nestor Goulart Reis Filho reproduzida do livro de viagem ao Reino Brasileiro - Sociedade de Geografia de Lisboa - CD ROM Imagens de vilas e cidades do Brasil Colonial, 2000.

Desde então, a região da Baixada, por meio do Porto de Santos, sempre foi o principal escoadouro da produção de São Paulo, e ponto por onde entra grande parte dos insumos que viabilizam esta produção. Durante os primeiros séculos, o porto de Santos era, sobretudo, um entreposto voltado para o comércio do sal que se destinava ao abastecimento das vilas do litoral e do planalto. Após o século XVIII, Santos tornou-se ponto de escoamento da produção derivada da cultura da cana-de-açúcar.

Porém, o grande porto comercial, como hoje se conhece, com o cais em cantaria e seus armazéns enfileirados em extensas áreas de aterro, teve sua construção iniciada apenas no último quartel do século XIX, em função da necessidade de escoamento da produção cafeeira do interior da então Província de São Paulo.

$\mathrm{Na}$ época foram substituídos os trapiches ${ }^{1}$ e pontes de madeira, implantando-se, aos poucos, grande infraestrutura de transporte e equipamentos, a qual consolidou o papel do Porto de Santos, de principal entreposto paulista.

Em função desse papel, e sua relação com o planalto paulista, a Baixada Santista passou a abrigar, no século $X X$, um importante parque petroquímico e siderúrgico, no município de Cubatão. Segundo GOLDENSTEIN (1993: 24), o parque de Cubatão "é a industrialização de São Paulo que se prolongou até a raiz da serra, onde um espaço altamente industrializado se apresenta em completa simbiose com o complexo industrial da metrópole, do ponto de vista da decisão, da comercialização e da destinação da produção".

Esse vínculo com São Paulo, conforme o ciclo econômico, alterou-se em intensidade, mas nunca deixou de existir e ser fundamental para as duas regiões metropolitanas e, mais recentemente, para grande parte do mercado das regiões sudeste e centro-oeste do Brasil.

\footnotetext{
${ }^{1}$ Os trapiches eram construções de madeira, junto aos molhes, aqui denominados pontes de atracação, onde eram armazenadas as
} mercadorias que passavam pelo porto. 
Por outro lado, desde princípio do século XX, mas em maior grau a partir da metade desse século, a região assentou grande parte de sua economia no turismo balneário, o qual desenvolveu-se em todos os municípios, a exceção de Cubatão, que não possui litoral.

Compõem a RMBS os municípios de Santos, São Vicente, Itanhaém, Cubatão, Guarujá, Praia Grande, Peruíbe, Mongaguá e Bertioga (ver Figura 3). Os três primeiros originaram os demais, que foram conquistando suas emancipações durante o século XX (ver Tabela 1). Os limites continentais da RMBS são: a Região Metropolitana de São Paulo - RMSP - ao oeste, o Litoral Norte ao norte e - Litoral Sul e Vale do Ribeira ao sul e sudoeste, respectivamente.

A área total da região é de $2.373 \mathrm{Km}^{2}$, e sua população estimada para 2000 era de 1.474 .665 habitantes $^{2}$. O município pólo é Santos, que concentra a maior rede de serviços e sedes de órgãos públicos e privados da RMBS, possuindo área total de $271 \mathrm{Km}^{2}$, dos quais $39 \mathrm{Km}^{2}$ situamse na llha de São Vicente e o restante na sua área continental. A população santista é de 417.777 habitantes $^{3}$, dos quais cerca de 99,5\% residem na área insular (ver Tabela 4 e 5).

De fato, a llha de São Vicente, localizada no centro da Baixada Santista, é compartilhada pela sede dos municípios de Santos e São Vicente. Este último possui cerca de

\footnotetext{
${ }^{2}$ Fonte: Fundação IBGE; Censo Demográfico de 2000 - Resultados Preliminares (Ver Tabela 4).

${ }^{3}$ Fonte: Fundação IBGE; Censo Demográfico de 2000 - Resultados Preliminares (Ver Tabela 4)
}

70.000 habitantes em sua área continental ${ }^{4}$. Os demais municípios localizam-se no continente, a exceção de Guarujá, inteiramente situado na llha de Santo Amaro.

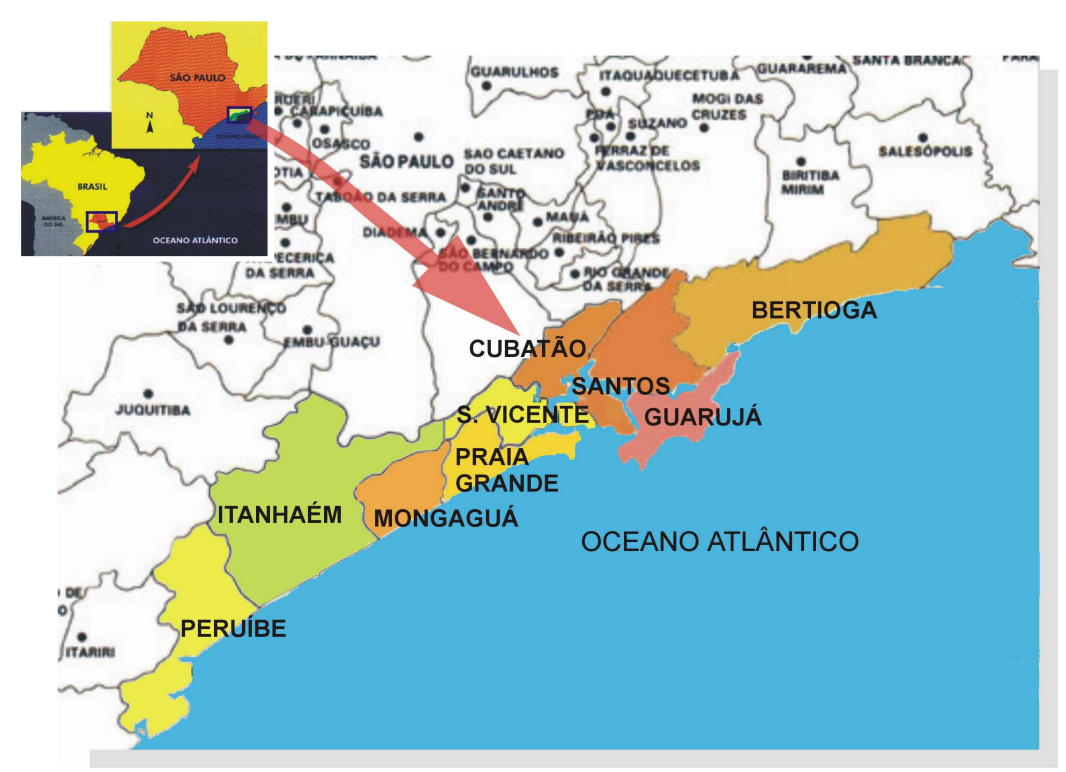

Figura 3 - Localização e Divisão Política dos municípios da Região Metropolitana da Baixada Santista.

\footnotetext{
${ }^{4}$ Fonte: estimativa da Prefeitura Municipal de São Vicente, baseada em dados demográficos da região, de 1994
} 
Tabela 1

\section{Sinopse dos Desmembramentos Ocorridos nos Municípios da RMBS - 1940/1998}

\begin{tabular}{|c|c|c|c|c|c|c|}
\hline $1940^{(1)}$ & $1950^{(1)}$ & $1960^{(1)}$ & $1970^{(1)}$ & $1980^{(1)}$ & $1991^{(1)}$ & $1998^{(2)}$ \\
\hline Guarujá ------ & Guarujá ------ & Guarujá ------ & Guarujá ----- & Guarujá ----- & Guarujá ------ & Guarujá \\
\hline \multirow[t]{4}{*}{ Itanhaém ---- } & Itanhaém ---- & Itanhaém ---- & Itanhaém ---- & Itanhaém ---. & Itanhaém ---- & Itanhaém \\
\hline & & Mongaguá --- & Mongaguá -- & Mongaguá --- & Mongaguá -- & Mongaguá \\
\hline & & Peruíbe ------ & Peruíbe ------ & Peruíbe ------ & Peruíbe ----- & Peruíbe \\
\hline & Itariri ${ }^{(3)}$ & Itariri $^{(3)}$ & |tariri ${ }^{(3)}$ & Itariri $^{(3)}$ & Itariri $^{(3)}$ & Itariri ${ }^{(3)}$ \\
\hline \multirow[t]{3}{*}{ Santos ------- } & Santos ----- & Santos - & Santos - & Santos ------ & Santos ------- & Santos \\
\hline & & & & & & Bertioga \\
\hline & Cubatão ----- & Cubatão ----- & Cubatão ----- & Cubatão ----- & Cubatão ----- & Cubatão \\
\hline \multirow[t]{2}{*}{ São Vicente } & São Vicente - & São Vicente & São Vicente & São Vicente - & São Vicente & São Vicente \\
\hline & & & Praia Grand & Praia Grande & Praia Grande & Praia Grande \\
\hline
\end{tabular}

Fonte: IBGE; Sinopse Preliminar do Censo Demográfico de S. Paulo, 1960 e 1970; Quadro Territorial, Administrativo e Judiciário do Estado de S. Paulo - várias edições, Machado Jr., Armando Marcondes - "Criação dos Municípios do Estado de S. Paulo", 1989, Diário Oficial de 31.12.1991. Elaboração: Emplasa, 1999.

(1) Municípios existentes à data dos respectivos censos.

(2) Municípios atualmente existentes.

(3) Município não pertencente à região considerada. 


\subsection{Caracterização socioeconômica da RMBS}

A economia dos municípios centrais da Baixada Santista Santos, São Vicente, Cubatão e Guarujá - é baseada no tripé porto, indústria e turismo. O Porto de Santos estendese por três municípios: Santos, margem direita; Guarujá, margem esquerda e Cubatão, no fundo do estuário. O parque industrial da RMBS está praticamente todo localizado em Cubatão, onde se instalaram, ao longo do século XX, indústrias pesadas, como a Refinaria Presidente Bernardes, da Petrobrás; a Companhia Siderúrgica Paulista - COSIPA e indústrias na área química, como a Ultrafértil, Carbocloro e Rodhia (ver Figura 5).

O turismo de natureza predominantemente balneária desenvolveu-se, também, ao longo do século passado, tendo sua maior fase de expansão após a inauguração da Rodovia Padre Anchieta (ver Figura 5), que liga o planalto paulista ao litoral centro-sul da Baixada Santista. À exceção de Cubatão, que se situa no fundo do complexo estuarino de Santos, as demais cidades da RMBS tiveram grande incremento na atividade imobiliária vinculada ao turismo balneário.

Estes setores foram responsáveis pelo crescimento de uma rede terciária expressiva, que tem nos municípios de Santos, São Vicente e Guarujá suas maiores expressões (ver tabelas 2 e 3). Nos demais municípios, sobretudo em Itanhaém e Peruíbe, que possuem grandes territórios de planície, entre a Serra do Mar e a orla marítima, a atividade agropecuária ainda é significativa. Porém, mesmo nesses municípios, cada vez mais a economia baseia-se na atividade turística balneária, com forte crescimento do setor imobiliário.
No aspecto demográfico, como se pode observar nas tabelas 4 e 5, a maior parte da população concentra-se nos municípios centrais, nos quais, o índice de urbanização é bem superior à média nacional, que está por volta de $80 \%$, segundo resultados preliminares do Censo demográfico 2000, da Fundação IBGE. Em Santos, esse índice atingiu $99,65 \%$, no final do século XX. Em São Vicente é de 99,95\%, em Cubatão 99,40\% e em Guarujá 99,97\%.

As densidades demográficas por município são de: $1.490,46 \mathrm{hab} / \mathrm{Km}^{2}$ em Santos; $2.039,41 \mathrm{hab} / \mathrm{Km}^{2}$ em São Vicente; 758,23 hab/ $/ \mathrm{Km}^{2}$ em Cubatão; e 1.858,30 hab/ $/ \mathrm{Km}^{2}$,

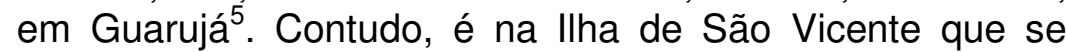
concentra a maior parte da população, ocupando território bastante restrito de $57 \mathrm{Km}^{2}$, com densidade aproximada de $11.762 \mathrm{hab} / \mathrm{Km}^{2}$.

Portanto, se forem consideradas apenas as áreas insulares de Santos e São Vicente, poder-se-á concluir que estas cidades possuem densidades superiores aos municípios de maior densidade do Estado de São Paulo, como Diadema, Osasco e Carapicuíba, por exemplo, que possuem densidades de 11.626,20 hab/ $\mathrm{Km}^{2} ; 10.026,37 \mathrm{hab} / \mathrm{Km}^{2}$; e $9.828,24$, respectivamente ${ }^{6}$.

Contudo, ao redor da Ilha de São Vicente, na área continental do município de São Vicente; no distrito de Vicente de Carvalho, em Guarujá; e em Cubatão, concentram-se aproximadamente mais 280.000 habitantes, segundo dados das Prefeituras locais. Assim, pode-se afirmar que o território estuarino central da RMBS é uma área de grande densidade demográfica.

\footnotetext{
${ }^{5}$ Fonte: Sinopse preliminar do Censo Demográfico 2000 FIBGE.

${ }^{6}$ Fonte: Sinopse preliminar do Censo Demográfico 2000 FIBGE.
} 
Legislação urbanística e segregação espacial nos municípios centrais da Região Metropolitana da Baixada Santista

\section{Tabela 2}

Distribuição do Número de Estabelecimentos por Setores de Atividade Econômica, segundo os Municípios: 1997

\begin{tabular}{|c|c|c|c|c|c|c|c|c|c|c|c|c|c|c|}
\hline \multirow[t]{2}{*}{ Municípios } & \multicolumn{2}{|c|}{ Agropecuária } & \multicolumn{2}{|c|}{ Indústria } & \multicolumn{2}{|c|}{ Comércio } & \multicolumn{2}{|c|}{ Serviços } & \multicolumn{2}{|c|}{ Adm. Publica ${ }^{(1)}$} & \multicolumn{2}{|c|}{ Outros $^{(2)}$} & \multicolumn{2}{|c|}{ Total } \\
\hline & №s Abs. & $\%$ & №s Abs. & $\%$ & $\mathrm{~N} \cong \mathrm{s}$ Abs. & $\%$ & №s Abs. & $\%$ & $\begin{array}{l}\mathrm{N} \cong \mathrm{O} \\
\text { Abs. }\end{array}$ & $\%$ & $\begin{array}{l}\text { №s } \\
\text { Abs. }\end{array}$ & $\%$ & №s Abs. & $\%$ \\
\hline Bertioga & 2 & 0,79 & 49 & 1,93 & 150 & 1,79 & 219 & 1,45 & 1 & 1,61 & - & - & 421 & 1,59 \\
\hline Cubatão & 2 & 0,8 & 167 & 6,6 & 370 & 4,4 & 405 & 2,7 & 6 & 9,7 & 1 & 1,1 & 951 & 3,6 \\
\hline Guarujá & 30 & 11,8 & 342 & 13,5 & 1.115 & 13,3 & 2.212 & 14,7 & 5 & 8,1 & 10 & 10,9 & 3.714 & 14,1 \\
\hline Itanhaém & 24 & 9,45 & 90 & 3,54 & 393 & 4,69 & 255 & 1,69 & 4 & 6,45 & - & - & 766 & 2,90 \\
\hline Mongaguá & 4 & 1,6 & 53 & 2,1 & 183 & 2,2 & 178 & 1,2 & 2 & 3,2 & 2 & 2,2 & 422 & 1,6 \\
\hline Peruíbe & 13 & 5,1 & 52 & 2,0 & 335 & 4,0 & 251 & 1,7 & 2 & 3,2 & 1 & 1,1 & 654 & 2,5 \\
\hline Praia Grande & 3 & 1,2 & 437 & 17,2 & 904 & 10,8 & 1.807 & 12,0 & 4 & 6,5 & 6 & 6,5 & 3.161 & 12,0 \\
\hline Santos & 173 & 68,1 & 1.067 & 42,0 & 3.835 & 45,8 & 8.400 & 55,7 & 28 & 45,2 & 68 & 73,9 & 13.571 & 51,4 \\
\hline São Vicente & 3 & 1,2 & 282 & 11,1 & 1.096 & 13,1 & 1.365 & 9,0 & 10 & 16,1 & 4 & 4,3 & 2.760 & 10,4 \\
\hline RMBS & 274 & 100,0 & 2.539 & 100,0 & 8.381 & 100,0 & 15.092 & 100,0 & 62 & 100,0 & 92 & 100,0 & 26.420 & 100,0 \\
\hline
\end{tabular}

Fonte: Ministério de Trabalho; Relação Anual de Informações Sociais, 1997. Elaboração: Emplasa, 1999. (1) Administração Pública, Defesa e Seguridade Social. (2) Atividades não informadas e ignoradas. 
Legislação urbanística e segregação espacial nos municípios centrais da Região Metropolitana da Baixada Santista

Tabela 3

Distribuição do Número de Estabelecimentos por Setores de Atividade Econômica, segundo os Municípios: 1997

\begin{tabular}{|c|c|c|c|c|c|c|c|}
\hline Municípios & Agropecuária & Indústria & Comércio & Serviços & Adm. Publica ${ }^{(1)}$ & Outros $^{(2)}$ & Total \\
\hline Bertioga & 0,5 & 11,6 & 35,6 & 52,0 & 0,2 & 0,0 & 100,0 \\
\hline Cubatão & 0,2 & 17,6 & 38,9 & 42,6 & 0,6 & 0,1 & 100,0 \\
\hline Guarujá & 0,8 & 9,2 & 30,0 & 59,6 & 0,1 & 0,3 & 100,0 \\
\hline Itanhaém & 3,1 & 11,7 & 51,3 & 33,3 & 0,5 & 0,0 & 100,0 \\
\hline Mongaguá & 0,9 & 12,6 & 43,4 & 42,2 & 0,5 & 0,5 & 100,0 \\
\hline Peruíbe & 2,0 & 8,0 & 51,2 & 38,4 & 0,3 & 0,2 & 100,0 \\
\hline Praia Grande & 0,1 & 13,8 & 28,6 & 57,2 & 0,1 & 0,2 & 100,0 \\
\hline Santos & 1,3 & 7,9 & 28,3 & 61,9 & 0,2 & 0,5 & 100,0 \\
\hline São Vicente & 0,1 & 10,2 & 39,7 & 49,5 & 0,4 & 0,1 & 100,0 \\
\hline RMBS & 1,0 & 9,6 & 31,7 & 57,1 & 0,2 & 0,3 & 100,0 \\
\hline
\end{tabular}

Fonte: Ministério de Trabalho; Relação Anual de Informações Sociais, 1997. Elaboração: Emplasa, 1999. (1) Administração Pública, Defesa e Seguridade Social.

(2) Atividades não informadas e ignoradas. 
Do ponto de vista geográfico, Santos e São Vicente possuem condições semelhantes, com a sede do município na área insular e a maior parte do território no continente. No entanto, a distribuição das populações em seus territórios é distinta. Santos possui a totalidade de sua população urbana na área insular e São Vicente possui cerca de $24 \%$ da população habitando sua área continental (ver mancha urbana na Figura 5).

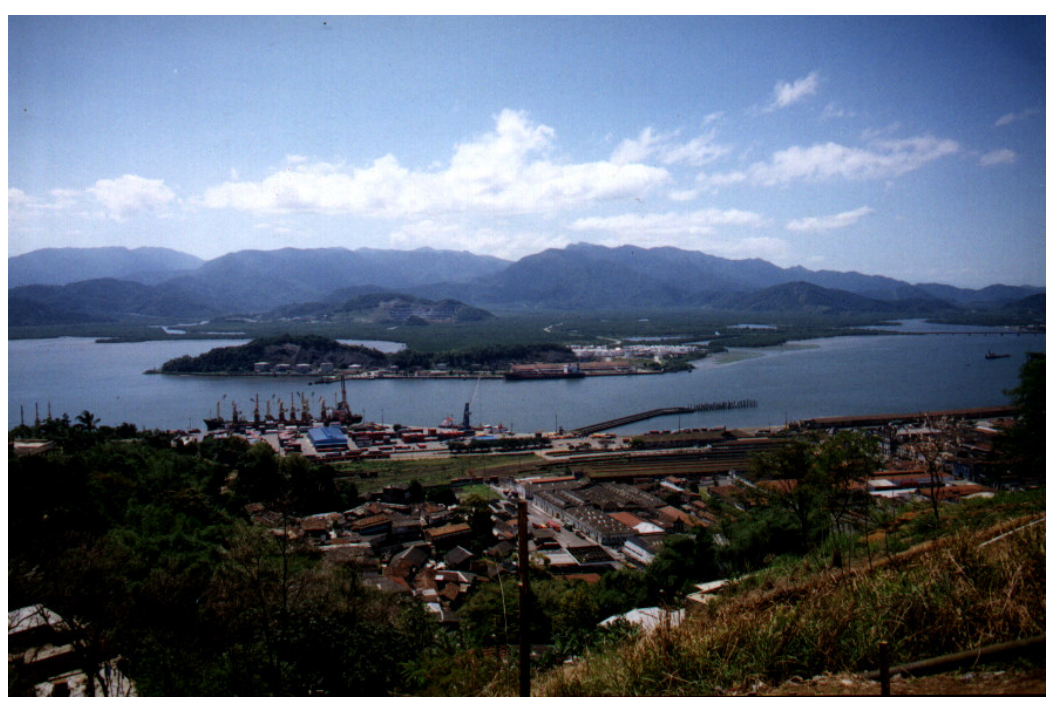

Figura 4 - Vista da área continental do município de Santos - ao fundo -, a partir dos morros de sua área insular. Foto do autor, 2001.

Cubatão, município inteiramente continental, possui a totalidade de sua população distribuída entre os contrafortes da Serra do Mar e o estuário. Guarujá insere-se completamente na Ilha de Santo Amaro, dividida pela cadeia de montanhas denominada Serra de Santo Amaro.
$\mathrm{Na}$ verdade essa serra separa a sede do município, ao longo da orla marítima e seu distrito de Vicente de Carvalho, onde se concentra grande parte da população, ao longo do canal do estuário. 


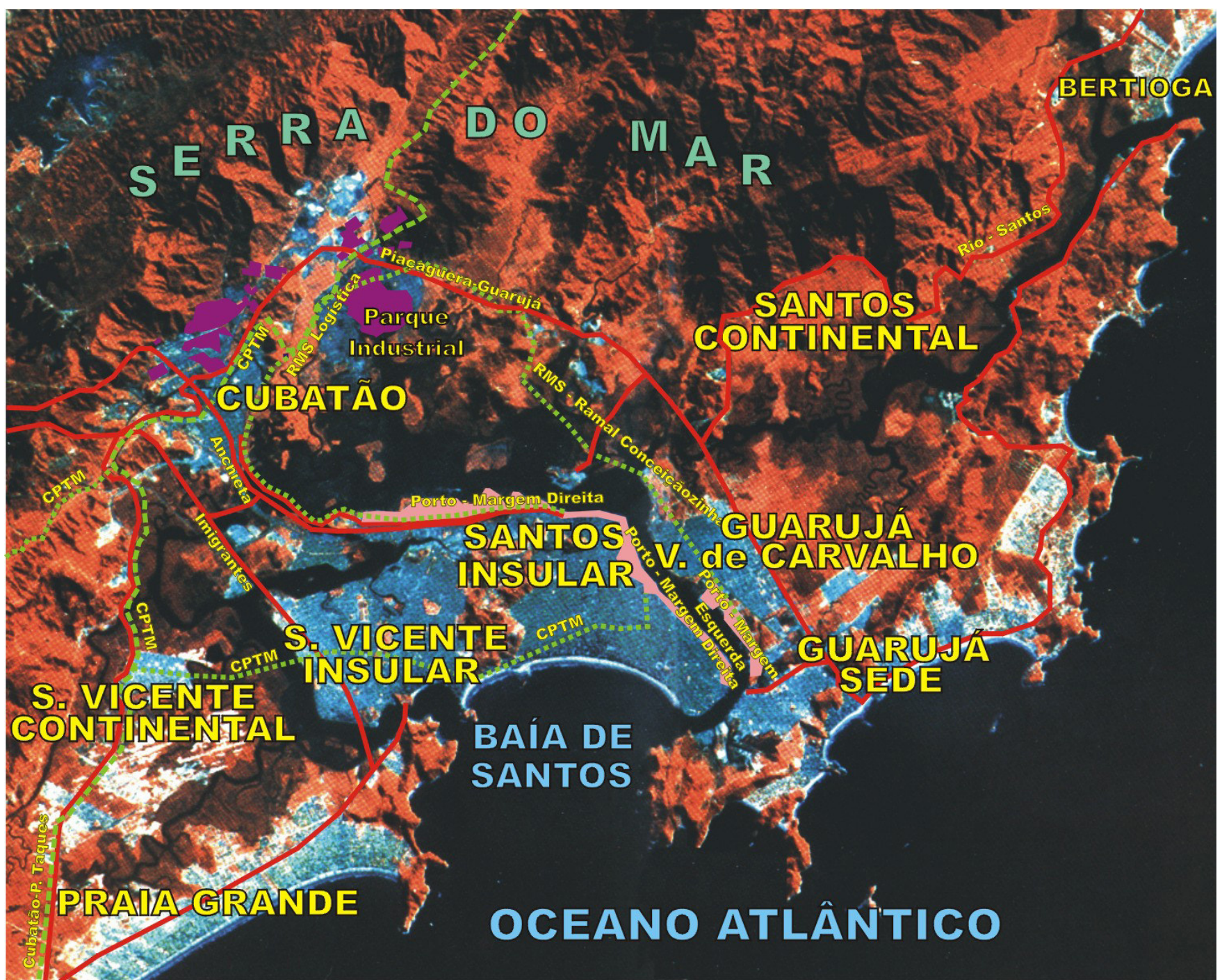

Figura 5 - Distribuição do território dos municípios centrais da RMBS, segundo áreas geográficas, sobre foto de satélite, localização do Porto, Parque Industrial de Cubatão e principais eixos rodo e ferroviários. Fonte: Instituto Nacional de Pesquisas Espaciais, 1997. 
Tabela 4

População residente, por situação do domicílio e sexo e taxa de crescimento anual dos municípios da RMBS 1996/2000

\begin{tabular}{|c|c|c|c|c|c|c|c|c|c|c|c|}
\hline \multirow{4}{*}{$\begin{array}{c}\text { Municípios } \\
\text { da RMBS }\end{array}$} & \multicolumn{10}{|c|}{ População residente } & \multirow{4}{*}{$\begin{array}{c}\text { Taxa de } \\
\text { crescimentc } \\
\text { anual (3) }\end{array}$} \\
\hline & \multirow{3}{*}{$\begin{array}{c}\text { Em } \\
01.08 .1996 \\
\text { (1) }\end{array}$} & \multicolumn{9}{|c|}{ Em 01.08.2000 (2) } & \\
\hline & & \multicolumn{3}{|c|}{ Total } & \multicolumn{3}{|c|}{ Urbano } & \multicolumn{3}{|c|}{ Rural } & \\
\hline & & Total & Homens & Mulheres & Total & Homens & Mulheres & Total & Homens & Mulheres & \\
\hline Santos & 412243 & 417777 & 193250 & 224527 & 415543 & 192079 & 223464 & 2234 & 1171 & 1063 & 0,33 \\
\hline São Vicente & 279528 & 302678 & 146760 & 155918 & 302541 & 146674 & 155867 & 137 & 86 & 51 & 2,01 \\
\hline Praia Grande & 150388 & 191811 & 93567 & 98244 & 191811 & 93567 & 98244 & 0 & 0 & 0 & 6,27 \\
\hline Peruíbe & 41398 & 51384 & 25591 & 25793 & 50297 & 24957 & 25340 & 1087 & 634 & 453 & 5,55 \\
\hline Mongaguá & 27065 & 35106 & 18004 & 17102 & 34950 & 17912 & 17038 & 156 & 92 & 64 & 6,72 \\
\hline Itanhaém & 58017 & 71947 & 35736 & 36211 & 71100 & 35242 & 35858 & 847 & 494 & 353 & 5,53 \\
\hline Guarujá & 226365 & 265155 & 130985 & 134170 & 265076 & 130942 & 134134 & 79 & 43 & 36 & 4,03 \\
\hline Cubatão & 97257 & 107904 & 54296 & 53608 & 107260 & 53961 & 53299 & 644 & 335 & 309 & 2,63 \\
\hline Bertioga & 17002 & 30903 & 16003 & 14900 & 30039 & 15524 & 14515 & 864 & 479 & 385 & 16,11 \\
\hline Total & 1309263 & 1474665 & 714192 & 760473 & 1468617 & 710858 & 757759 & 6048 & 3334 & 2714 & \\
\hline
\end{tabular}

Fontes: FIBGE, Contagem da População 1996 e Censo Demográfico 2000 - Resultados Preliminares.

(1) Redistribuição da população de acordo com a divisão territorial vigente em 10 de agosto de 2000.

(2) Resultados preliminares. (3) Taxa média geométrica de incremento anual da população residente. 
Legislação urbanística e segregação espacial nos municípios centrais da Região Metropolitana da Baixada Santista

\section{Tabela 5}

Evolução da População Residente, por Situação do Domicílio, segundo os Municípios da RMBS: 1970 - 1980 - 1991 1996

\begin{tabular}{|c|c|c|c|c|c|c|c|c|c|c|c|c|}
\hline \multirow[t]{2}{*}{ Municípios } & \multicolumn{3}{|c|}{1970} & \multicolumn{3}{|c|}{1980} & \multicolumn{3}{|c|}{1991} & \multicolumn{3}{|c|}{1996} \\
\hline & Urbana & Rural & Total & Urbana & Rural & Total & Urbana & Rural & Total & Urbana & Rural & Total \\
\hline Bertioga & 2.572 & 1.003 & 3.575 & 3.777 & 456 & 4.233 & 11.315 & 158 & 11.473 & 16.167 & 835 & 17.002 \\
\hline Cubatão & 37.147 & 13.759 & 50.906 & 78.303 & 327 & 78.630 & 90.659 & 477 & 91.136 & 96.693 & 564 & 97.257 \\
\hline Guarujá & 90.514 & 3.507 & 94.021 & 151.127 & - & 151.127 & 210.192 & 15 & 210.207 & 226.357 & 8 & 226.365 \\
\hline Itanhaém & 12.265 & 2.250 & 14.515 & 26.163 & 1.301 & 27.464 & 44.820 & 1.254 & 46.074 & 57.326 & 691 & 58.017 \\
\hline Mongaguá & 4.660 & 554 & 5.214 & 9.826 & 101 & 9.927 & 18.904 & 122 & 19.026 & 26.963 & 102 & 27.065 \\
\hline Peruíbe & 6.063 & 903 & 6.966 & 17.048 & 1.359 & 18.407 & 31.311 & 1.462 & 32.773 & 40.295 & 1.103 & 41.398 \\
\hline Praia Grande & 19.671 & 33 & 19.704 & 66.011 & - & 66.011 & 123.492 & - & 123.492 & 150.388 & - & 150.388 \\
\hline Santos & 340.855 & 1.200 & 342.055 & 410.933 & 1.515 & 412.448 & 415.958 & 1.492 & 417.450 & 410.496 & 1.747 & 412.243 \\
\hline São Vicente & 115.935 & 550 & 116.485 & 192.858 & 144 & 193.002 & 268.353 & 265 & 268.618 & 279.346 & 182 & 279.528 \\
\hline Total & 629.682 & 23.759 & 653.441 & 956.046 & 5.203 & 961.249 & 1.215 .004 & 5.245 & 1.220 .249 & 1.304 .031 & 5.232 & 1.309 .263 \\
\hline
\end{tabular}

Fonte: FIBGE; Censos Demográficos de 1970, 1980, 1991 e Contagem da População, 1996. 
Tabela 6

Área, Localização Geográfica e Altitude dos Municípios da RMBS

\begin{tabular}{|c|c|c|c|c|c|}
\hline \multirow[t]{2}{*}{ Municípios } & \multicolumn{2}{|c|}{ Área $\left(\mathrm{km}^{2}\right)$} & \multicolumn{2}{|c|}{ Localização Geográfica } & \multirow{2}{*}{$\begin{array}{l}\text { Altitude } \\
\text { Metros }\end{array}$} \\
\hline & №s Abs. & $\%$ & Latitude & Longitude & \\
\hline Bertioga & 482 & 20,3 & $23^{\circ} 50^{\prime} 47^{\prime \prime}$ & $46^{\circ} 08^{\prime} 21^{\prime \prime}$ & 10 \\
\hline Cubatão & 148 & 6,2 & $23^{\circ} 53^{\prime} 30^{\prime \prime}$ & $46^{\circ} 25^{\prime} 30^{\prime \prime}$ & 10 \\
\hline Guarujá & 137 & 5,8 & $23^{\circ} 59^{\prime} 14^{\prime \prime}$ & $46^{\circ} 13^{\prime} 49^{\prime \prime}$ & 10 \\
\hline Itanhaém & 581 & 24,5 & $24^{\circ} 11^{\prime} 01^{\prime \prime}$ & $46^{\circ} 47^{\prime} 18^{\prime \prime}$ & 3 \\
\hline Mongaguá & 135 & 5,7 & $24^{\circ} 05^{\prime} 35^{\prime \prime}$ & $46^{\circ} 37^{\prime} 10^{\prime \prime}$ & 10 \\
\hline Peruíbe & 328 & 13,8 & $24^{\circ} 19^{\prime} 18^{\prime \prime}$ & $46^{\circ} 59^{\prime} 55^{\prime \prime}$ & 5 \\
\hline Praia Grande & 145 & 6,1 & $24^{\circ} 00^{\prime} 35^{\prime \prime}$ & $46^{\circ} 24^{\prime} 45^{\prime \prime}$ & 5 \\
\hline Santos & 271 & 11,4 & $23^{\circ} 57^{\prime} 35^{\prime \prime}$ & $46^{\circ} 19^{\prime} 56^{\prime \prime}$ & 10 \\
\hline São Vicente & 146 & 6,2 & $23^{\circ} 57^{\prime} 30^{\prime \prime}$ & $46^{\circ} 23^{\prime} 15^{\prime \prime}$ & 10 \\
\hline Região Metropolitana da Baixada Santista & 2.373 & 100,0 & & & \\
\hline
\end{tabular}

Fonte: Instituto Geográfico e Cartográfico. Elaboração: EMPLASA, 1999. 


\subsection{As condições habitacionais na RMBS}

A RMBS, como as demais regiões metropolitanas brasileiras, apresenta um enorme desequilíbrio social na distribuição da população em seu território. Da mesma forma como ocorre em São Paulo, Rio de Janeiro, Belo Horizonte e Salvador, por exemplo, a população de mais alta renda concentra-se em pequena parcela do território, enquanto a população de baixa renda, em muito maior número, ocupa a maior parte das áreas habitadas da região.

O desequilíbrio encontra-se no fato de que a camada de alta renda habita áreas dotadas satisfatoriamente de infraestrutura urbana, de equipamentos públicos, de comércio e de serviços, enquanto a baixa renda distribui-se em áreas onde esses fatores não estão presentes em níveis aceitáveis.

Segundo dados da Secretaria Municipal de Saúde de Santos, para o ano de 2000, enquanto em alguns bairros como Gonzaga, Boqueirão e Ponta da Praia, áreas onde habita população de média e alta renda, a média da mortalidade infantil ficou em 0 (zero), em bairros de baixa renda a média ficou, em alguns casos, em níveis comparáveis à região nordeste (ver tabelas 7 e 8).
Tabela 7

Índice de mortalidade infantil em alguns bairros da Cidade de Santos

\begin{tabular}{|l|c|}
\hline \multicolumn{1}{|c|}{ Bairro } & Média em 2000 \\
\hline Gonzaga & 0 \\
\hline Boqueirão & 0 \\
\hline Ponta da Praia & 0 \\
\hline Vila Mathias & 10,3 \\
\hline Vila Nova & 13,7 \\
\hline Centro & 54.8 \\
\hline Paquetá & 57,1 \\
\hline
\end{tabular}

Média para cada grupo de mil crianças nascidas vivas. Fonte: Secretaria Municipal de Saúde, 2000.

Obs.: Os bairros Vila Mathias, Vila Nova e Paquetá são bairros contíguos ao Centro de Santos (ver Figura 6).

\section{Tabela 8}

Índice de mortalidade infantil por região do Brasil

\begin{tabular}{|l|c|}
\hline \multicolumn{1}{|c|}{ Região } & Média em 2000 \\
\hline Norte & 32,7 \\
\hline Nordeste & 52,8 \\
\hline Sudeste & 25,7 \\
\hline Sul & 22,8 \\
\hline Centro-Oeste & 26,1 \\
\hline Brasil & $\mathbf{3 4 , 8}$ \\
\hline
\end{tabular}

Média para cada grupo de mil crianças nascidas vivas. Fonte: Fundação IBGE, 2000 
Conforme avaliação da Secretaria Municipal de Saúde, esses resultados dispares se devem às péssimas condições de moradia, especialmente junto ao Centro da Cidade, onde grande parte da população vive em cortiços, e os índices de contaminados por doenças como tuberculose e AIDS é alarmante.

Entretanto, essas péssimas condições de moradia não se restringem às proximidades da área central de Santos, muito menos a esse único município. Na RMBS, em todos os municípios podem ser identificadas áreas onde a população vive em péssimas condições de vida.

Da mesma forma que em outros grandes aglomerados urbanos do Estado de São Paulo, na RMBS muitas das áreas ocupadas pela população de baixa renda não possuem sequer saneamento básico, e milhares de famílias vivem em constante risco sanitário, ou mesmo em risco geológico.

Porém, conforme revelou pesquisa da Fundação Sistema Estadual de Análise de Dados - SEADE, sobre as condições de vida nas principais regiões do interior do Estado de São Paulo, a situação da RMBS é a mais grave do estado, excetuando-se a RMSP. 


\subsubsection{A Pesquisa de Condições de Vida - PCV - da Fundação SEADE}

A Pesquisa de Condições de Vida - PCV - da Fundação $\mathrm{SEADE}^{7}$ teve sua primeira versão em 1990 e foi reaplicada em 1994 e em 1998. Guardando uma periodicidade quadrienal, segundo informa a fundação, "este levantamento tem permitido à sociedade, aos analistas e aos formuladores de políticas públicas acompanharem a evolução da situação socioeconômica da população paulista no período recente". Para o presente estudo utilizou-se dados da referida pesquisa, por ser esta a fonte mais confiável e sistemática, a permitir a comparação das condições habitacionais da RMBS com as demais regiões do estado.

Esta nova PCV, além de coletar informações em todos os municípios da Região Metropolitana de São Paulo, ampliou sua cobertura do interior do Estado, com a incorporação em sua base amostral de todos os municípios paulistas com população urbana superior a 50.000 habitantes $^{8}$, passando a fornecer informações socioeconômicas sobre uma das áreas geográficas mais importantes do país que, paradoxalmente, não tem sido objeto de levantamentos sistemáticos de informações, salvo os Censos Demográficos.

\footnotetext{
${ }^{7}$ A PCV da Fundação SEADE está disponível no sítio da rede mundial de computadores www.seade.gov.br.

${ }^{8}$ Metodologicamente, o interior do Estado de São Paulo foi dividido em seis agrupamentos de municípios, da seguinte forma: Central - Bauru, Jaú, Sorocaba e outros; Leste - Campinas, Piracicaba, Mogi Mirim e outros; Norte - Ribeirão Preto, Barretos, Franca, Araraquara e outros; Oeste - S. José do Rio Preto, Presidente Prudente, Araçatuba, Ourinhos e outros; Vale do Paraíba e Região Metropolitana da Baixada Santista - RMBS
}

A publicação da PCV é composta de nove seções: aspectos demográficos; caracterização das famílias; condições habitacionais; situação educacional; inserção no mercado de trabalho; renda e patrimônio familiar; acesso a serviços de saúde; portadores de deficiência; e vítimas de crimes.

Em função da sua abordagem mais específica, para efeito do presente estudo, utilizou-se algumas informações da seção Condições Habitacionais, ainda que o cruzamento com outras seções da pesquisa permita reforçar o fato de que a segregação espacial na RMBS é significativamente maior que nas demais regiões do interior paulista.

\subsubsection{PCV-98 Condições Habitacionais}

Segundo pôde ser apurado pela PCV-98, "entre 1994 e 1998, aumentou em 5 pontos percentuais a proporção de famílias que moravam em residência própria no interior paulista, em detrimento daquelas que viviam em domicílio cedido e, em menor medida, invadido". Considerando as formas de obtenção da moradia própria, houve crescimento da parcela de famílias que contrataram mão-de-obra especializada para sua construção, reduzindo-se, em conseqüência, o percentual de autoconstrução. Segundo a SEADE, "tais resultados confirmam a hipótese de que a estabilização econômica, decorrente da implementação do Plano Real, possibilitou a uma parcela não desprezível de famílias obter a propriedade de sua moradia".

A casa de alvenaria isolada continuou sendo o tipo de edificação predominante no interior paulista, "mas aumentou, entre 1994 e 1998, a parcela de famílias que vivem em cortiços e em edificações insalubres ou mal conservadas", fenômeno não específico da RMBS. Mesmo 
assim, conforme apontou o relatório da PCV-98, "houve ampliação do acesso a serviços de infra-estrutura urbana, notadamente de esgotamento sanitário, e crescimento substancial da proporção de famílias que residem em ruas com pavimentação ou com guias e sarjetas".

\subsection{Tipo de Edificação}

Os dados de moradia, segundo tipo de edificação, mostraram um crescimento relativo dos cortiços, que passaram de 1,2\% em 1994 para 3,1\% em 1998 no interior paulista. As outras habitações tradicionalmente consideradas precárias - barracos isolados e moradias em favela - continuaram abrigando pouco mais de $3 \%$ das famílias.

O percentual de famílias do interior paulista que compartilhavam o mesmo terreno correspondeu a cerca de $20 \%$, nos dois anos analisados. Já aquelas que viviam em moradias que tinham, em princípio, o espaço privativo mais garantido registraram ligeira diminuição no mesmo período: a parcela de famílias que moravam em apartamento e em casa de alvenaria isolada passou de $12,1 \%$ para $10,1 \%$ e de $64,5 \%$ para $63,0 \%$, respectivamente.

Na RMBS, segundo aponta a PCV-98

"observam-se as maiores parcelas de moradias tradicionalmente consideradas precárias: $10,1 \%$ das famílias vivem em barracos isolados e moradias em favela (nos demais aglomerados aparecem em parcelas inferiores a $4 \%$ ); e outras $4,1 \%$ moram em cortiços (grifo do autor) - no aglomerado Central também ultrapassam a média do interior. Praticamente $30 \%$ das famílias litorâneas residem em apartamentos, parcela quase três vezes superior à média encontrada para o conjunto do interior paulista $(10,1 \%)$.

Dentre os agrupamentos urbanos, somente na RMBS as casas de alvenaria isoladas não abrigam mais da metade das famílias - 39,2\% - (grifo do autor). Nos demais, registram-se parcelas entre $75,1 \%$ no Norte e $58,6 \%$ no Leste. As casas de alvenaria frente-fundos correspondem a cerca de um quarto no agrupamento Leste e a $16,9 \%$ na RMBS, equivalendo esta última à menor parcela" (grifo do autor).

\subsection{Número de Cômodos}

Segundo a PCV-98,

"Entre 1994 e 1998, nos municípios do interior do Estado de São Paulo, aumentou a quantidade de famílias que moram em domicílios com maior espaço interno (as moradias com mais de cinco cômodos passaram de $43,0 \%$ para $45,7 \%$ ), em detrimento daquelas que vivem em espaço insuficiente (as moradias com menos de quatro cômodos passaram de $10,9 \%$ para $8,9 \%$ ) - o que pode ser conseqüência da inclusão, na amostra da PCV-98, de municípios com 50 mil a 80 mil habitantes em sua área urbana".

"A RMBS é o agrupamento urbano que apresenta a maior parcela de famílias residindo em moradias com até quatro cômodos (cerca de 30\%, sendo que 13,3\% dispõem de três cômodos ou menos e 16,6\% de quatro cômodos). Esta concentração de famílias morando em espaço reduzido, na região litorânea, pode ser explicada pelo grande número relativo de 
moradias precárias (barraco, favela e cortiço), além da alta parcela de apartamentos" ${ }^{\prime 9}$ (grifo do autor).

\subsection{Grau de Salubridade da Moradia}

Segundo a SEADE, um indicador importante no estudo das condições de habitabilidade, adotado pela PCV, foi o grau de salubridade das moradias. As questões apresentadas aos moradores permitiram a investigação das condições de arejamento e insolação, a eventual presença de manchas de umidade nas paredes ou no teto e de obstáculos que impedem a ventilação pelas janelas. Quando a moradia apresentava dois dos problemas mencionados em parte dos cômodos referidos - ou mais problemas em mais cômodos - foi classificada como insalubre.

Conforme apontou o relatório da PCV, "houve uma ligeira queda (1,2 pontos percentuais) de moradias adequadas em termos de salubridade. Na comparação entre agrupamentos urbanos, a RMBS apresenta, de longe, a maior quantidade de moradias insalubres, em proporção maior que o dobro da parcela encontrada para o conjunto do interior paulista 26,8\% e 12,8\%, respectivamente" (grifo do autor).

\subsection{Apropriação da Moradia}

Segundo revelou a PCV-98, "entre 1994 e 1998, aumentou a estabilidade das famílias do interior paulista quanto ao

\footnotetext{
${ }^{9}$ A verticalização da orla marítima é um fenômeno observado desde os anos 50 e que transformou a Baixada Santista na região do interior paulista com maior número de apartamentos, relativamente às outras tipologias habitacionais, ainda que muitos sejam ocupados por famílias do interior e da capital, durante os feriados e a temporada de verão. Por isso são chamados de segunda residência.
}

vínculo com sua moradia: houve crescimento relativo das famílias proprietárias (de 63,1\% para 68,2\%) e 0 proporcional decréscimo das que moram em habitações cedidas e das que ocupam ilegalmente seus domicílios (perto de quatro pontos percentuais a menos nas moradias cedidas e de $3,8 \%$ para $2,7 \%$ nas invadidas)".

No entanto, na RMBS, encontra-se "comparativamente, a menor parcela de famílias proprietárias $(59,1 \%)$. Em conseqüência, registra as maiores porcentagens de locatárias $(24,3 \%)$, de famílias em moradias cedidas $(9,3 \%)$ e de invasoras (7,3\%)" (grifo do autor). Estes números indicaram o grande peso que a moradia em favelas tem como alternativa habitacional para população de baixa renda na RMBS, e a falta de investimentos no setor habitacional para esta parcela da sociedade.

\subsection{Forma de Obtenção das Moradias Próprias}

Pela PCV-98, para as famílias proprietárias, "que correspondem a quase $70 \%$ do total no interior paulista, as formas para obter sua moradia compreendem compra, herança ou construção. Entre as que construíram, há aquelas que participaram diretamente da construção de suas casas e as que delegaram esse trabalho, com a contratação de mão-de-obra especializada".

Analisando-se as formas regionais de obter a moradia própria, "nota-se que as famílias que compraram seus domicílios estão abaixo da média $(49,4 \%)$ nos agrupamentos urbanos Leste, Central e Vale do Paraíba (48,5\%, 46,0\% e 44,1\%, respectivamente), enquanto na RMBS superam a média em sete pontos percentuais e no agrupamento Oeste em quase quatro pontos percentuais 
(grifo do autor). Nos agrupamentos urbanos da RMBS e do Vale do Paraíba, destacam-se as famílias residentes em moradias herdadas, com parcelas superiores em quase três pontos percentuais em relação à média" (grifo do autor).

A interpretação possível para estes dados pode estar em outra parte da PCV-98, em que a RMBS figurou como a região do interior paulista com maior concentração de renda. Ainda, alguns municípios da Baixada, sobretudo Santos, têm uma numerosa classe média. E, neste aspecto, os apartamentos de segunda residência, na orla marítima, podem ter peso significativo, ainda que nos anos 90 tenham ocorrido em menor número que em décadas anteriores.

Nos subconjuntos de moradias construídas, segundo a PCV-98, "houve uma certa oscilação, com aumento de dois pontos percentuais de famílias proprietárias que mandaram construir suas casas (de 14,0\% em 1994 para 16,0\% em 1998), contrapondo-se ao decréscimo das famílias que participaram da obra (de $29,2 \%$ para $27,0 \%$, no mesmo período). A RMBS tem o menor percentual de famílias em moradias próprias construídas por terceiros - 8,2\%, contra $16,0 \%$ na média" (grifo do autor).

Esses dados revelaram ser a autoconstrução uma alternativa de obtenção da moradia própria com maior relevância na RMBS. Essa situação pode, também, estar vinculada às dificuldades em acessar programas de financiamento de moradia, para população de baixa renda.

\subsection{Infra-Estrutura Urbana}

No conjunto de municípios pesquisados, houve ampliação na cobertura dos serviços urbanos nas vias públicas, entre 1994 e 1998. Os equipamentos que garantem a circulação de veículos - pavimentação, guias e sarjetas - registraram um aumento superior a cinco pontos percentuais e a iluminação pública atingiu 98,0\% das moradias urbanas do interior do Estado.

"Entre os agrupamentos considerados, o Norte apresenta as maiores extensões de cobertura - mais de $98 \%$ das famílias moram em ruas que dispõem dos três equipamentos. No outro extremo, a RMBS registra as parcelas mais baixas (grifo do autor). Quanto às quatro redes públicas de serviços urbanos, ligadas às moradias fornecimento de energia elétrica, abastecimento de água, coleta de lixo e esgotamento sanitário -, os índices de cobertura são superiores a $90 \%$ nos municípios do interior".

"A comparação entre agrupamentos urbanos, no entanto, mostra algumas diferenças, sobretudo no que se refere ao esgotamento sanitário. Enquanto a cobertura das redes de distribuição de energia elétrica e de água e a coleta de lixo são superiores a $94 \%$ em todos os agrupamentos, o esgoto varia entre $69,7 \%$ na RMBS e $98 \%$ nos agrupamentos urbanos Norte, Oeste, Central e Vale do Paraíba" (grifo do autor). 


\subsubsection{Considerações sobre os dados apresentados pela PCV-98 Condições Habitacionais}

Portanto, ao analisar-se os dados comparativos apresentados pela PCV-98, pode-se afirmar que as condições de moradia na RMBS são significativamente piores do que nas outras regiões do interior do estado. A partir desta constatação foi possível aprofundar a questão da segregação espacial nesta região. Ou seja, passou-se a estudar o processo de constituição de espaços bem definidos, no território da RMBS, onde habitam as parcelas da população de maior e menor renda, em que a mais rica logra garantir melhores localizações.

Esta divisão de territórios no espaço urbano, como destacou VILLAÇA (1998), é fundamental para a manutenção do privilégio, que os extratos de mais alta renda têm de atrair para "seus" territórios um maior número de investimentos públicos, seja em infra-estrutura, seja em equipamentos.

Para o caso específico da Baixada Santista, pretende-se demonstrar que, no decorrer do século $X X$, primeiramente com a introdução da legislação urbanística de caráter sanitarista e, sobretudo a partir da introdução do zoneamento do uso do solo urbano, de caráter funcionalista, a legislação urbanística reforçou essa segregação. Segundo VILLAÇA (1998: 320 ),

"As classes de mais alta renda escolhem a direção de crescimento (da área da cidade que ocupam), em função dos atrativos do sítio natural - como também concluiu Hoyt ${ }^{10}$ - e também, e principalmente, em

\footnotetext{
${ }^{10}$ HOYT, Homer (1959).
}

função da simbiose, da "amarração" que desenvolvem com suas áreas de comércio, serviços e emprego, ou seja, em virtude da sua inserção na estrutura urbana que elas próprias produzem. Essa estruturação se deu pelo controle que tais classes exercem sobre 0 mercado imobiliário e sobre o Estado, que para elas abriu, por exemplo, o melhor sistema viário das cidades, construiu seus locais mais aprazíveis, mais ajardinados e arborizados e controlou a ocupação do solo pela aplicação de uma legislação urbanística menos ineficaz" ${ }^{\prime 1}$.

Via de regra, o zoneamento funcionalista, e antes deste, a legislação sanitarista, facilitaram a definição de espaços mais privilegiados para as classes dominantes, do ponto de vista do acesso aos serviços públicos e infra-estrutura urbana. Se tal situação teve vínculo com uma sensível valorização imobiliária nestes locais, restringindo a faixa de renda da população capaz de estabelecer-se nestas áreas, é o que se pretende aprofundar nos capítulos 4 e 5 .

No caso específico da Baixada Santista, esse processo parece relacionar-se diretamente com a situação demonstrada pela PCV-98 Condições Habitacionais, e pode ser mais bem compreendido quando se analisar os dados referentes à concentração de renda, nas diversas regiões do estado, coletados pela mesma pesquisa, na seção Renda.

Nesse tópico, a Baixada figurou como a área com maior concentração de renda, o que poderia explicar, em parte, o desequilíbrio na ocupação de seu território e as más

\footnotetext{
${ }^{11}$ Esse é um dos pontos centrais que pretendemos abordar neste trabalho.
} 
condições de habitabilidade a que estão submetidas milhares de famílias de baixa renda.

Se forem tomados dados referentes às condições de moradia da população de baixa renda na Região Metropolitana de São Paulo - RMSP, disponíveis em várias obras de referência deste trabalho, como MARICATO (1996), ROLNIK (1997), e outros, perceberemos que as graves condições habitacionais da RMBS são comparáveis, guardadas as devidas proporções, em termos de Estado de São Paulo, somente à primeira.

$\mathrm{Na}$ verdade, o processo de industrialização das duas regiões, como apontou GOLDENSTEIN (1993), sempre guardou relação muito estreita. Pode-se dizer, também, que as conseqüências desse processo, em termos de segregação social, também foram semelhantes e, como ver-se-á no último capítulo, parece ter raízes comuns. 


\subsubsection{O déficit habitacional da RMBS segundo os municípios}

No ano de 1998, as prefeituras da RMBS, por solicitação do CONDESB, órgão que aglutina os prefeitos da região e representantes do Governo do Estado, apresentaram dados a respeito do déficit habitacional em seus respectivos municípios. Embora o grau de confiabilidade dos mesmos seja questionável, em função dos cadastros bastante defasados e metodologias de levantamento nem sempre adequadas, apresenta-se abaixo o resultado final do trabalho, que permite reforçar as questões já levantadas anteriormente. Mais do que isso, permite identificar os municípios centrais da RMBS como os que enfrentam maiores problemas com a questão habitacional. Portanto, este é o recorte espacial que orientou o presente estudo, ou seja, a segregação espacial nos municípios centrais da região, quais sejam: Santos, São Vicente, Cubatão e Guarujá.

O município de Praia Grande não constituiu objeto de aprofundamento deste trabalho, pois o fenômeno da ocupação subnormal em seu território, apesar de ter como conseqüência de forma preponderante a migração de grandes contingentes de trabalhadores não qualificados, atraídos pelo surto de construções destinadas ao turismo balneário, não guarda vínculos tão estreitos com os demais municípios centrais.

Assim, tal como ocorreu com Bertioga, Itanhaém, Mongaguá e Peruíbe, o município de Praia Grande não sofreu um processo significativo de ocupação desordenada vinculado ao porto, ao parque industrial de Cubatão e ao setor terciário de Santos, ainda que, cada vez mais, a população de baixa renda dos municípios centrais esteja procurando localizações a sudoeste. A ocorrência generalizada de favelas e o surgimento do loteamento irregular periférico são, portanto, fenômenos mais internos dos municípios do litoral sul.

Cabe ressaltar que nos municípios de São Vicente, Guarujá e Cubatão também surgiram assentamentos subnormais endógenos, mas proporcionalmente menos significativos do que em Praia Grande. Em São Vicente e Guarujá, esses assentamentos têm a mesma origem que em Praia Grande, ou seja, a construção civil vinculada ao turismo balneário. Em Cubatão isto se deve à construção civil ligada ao parque industrial.

\section{Tabela 9}

\section{Déficit Habitacional da Região Metropolitana da Baixada} Santista (1998)

\begin{tabular}{|l|c|c|}
\hline Município & Déficit $^{\star}$ & População** $^{\star *}$ \\
\hline Guarujá & 26.700 & 226.365 \\
\hline São Vicente & 20.000 & 279.528 \\
\hline Santos & 15.000 & 412.243 \\
\hline Praia Grande & 15.000 & 150.388 \\
\hline Cubatão & 8.242 & 97.257 \\
\hline Itanhaém & 8.500 & 58.017 \\
\hline Peruíbe & 5.000 & 41.398 \\
\hline Bertioga & 2.500 & 17.002 \\
\hline Mongaguá & 3.000 & 27.065 \\
\hline Total & $\mathbf{1 0 3 . 9 4 2}$ & $\mathbf{1 . 3 0 9 . 2 6 3}$ \\
\hline
\end{tabular}

* Em unidades habitacionais.

** População estimada Censo FIBGE - 1996.

Fonte: Câmara Temática de Habitação do CONDESB. Dados fornecidos pelas prefeituras. 
Legislação urbanística e segregação espacial nos municípios centrais da Região Metropolitana da Baixada Santista 
Legislação urbanística e segregação espacial nos municípios centrais da Região Metropolitana da Baixada Santista

3. A segregação espacial nos municípios centrais da RMBS 
Legislação urbanística e segregação espacial nos municípios centrais da Região Metropolitana da Baixada Santista 


\subsection{Evolução da distribuição das populações de baixa renda no território dos municípios centrais da RMBS}

"Na segunda-feira, mais um chalé pronto, mais uma familia abrigada: as sensações de posse, de proteção, a vitória do trabalho contra o desabrigo, o seguro contra a indesejável promiscuidade dos cortiços"

ANDRADE (1989: 214).

Uma peculiaridade da RMBS é sua condição de região litorânea, como o Rio de Janeiro ou Salvador, que fez com que a população residente de alta renda e a população flutuante ocupassem as áreas mais próximas da orla marítima. Segundo VILLAÇA (1998: 181):

"Como as condições de deslocamento condicionam a oferta de terra? A orla de alto-mar trouxe para as metrópoles litorâneas um traço singular de enormes repercussões políticas, urbanísticas, estéticopaisagísticas e culturais. As terras ao longo da orla começaram a ser privilegiadas a partir do final do século passado. Seus proprietários passaram então a ser detentores de um monopólio e sobre seus preços recaía um enorme componente de preço de monopólio. Sobre tais terras começou a incidir a demanda das burguesias para fins residenciais. Entretanto, sua oferta era restrita, e aqui entraram as condições e possibilidades de deslocamento como elemento que atuava na oferta de terra".

Sobretudo no caso de Santos, Guarujá, São Vicente e Praia Grande esta característica é evidente. Em relação a Santos este fenômeno foi tão marcante que a alta renda construiu, ao longo do século XX, em um bairro da orla - o Gonzaga um novo centro comercial e de prestação de serviços que atraiu para si muitas das empresas antes instaladas no centro da cidade, de maneira que grande parte da classe média rompeu quase inteiramente seus vínculos de consumo com esta área (ver Figura 6).

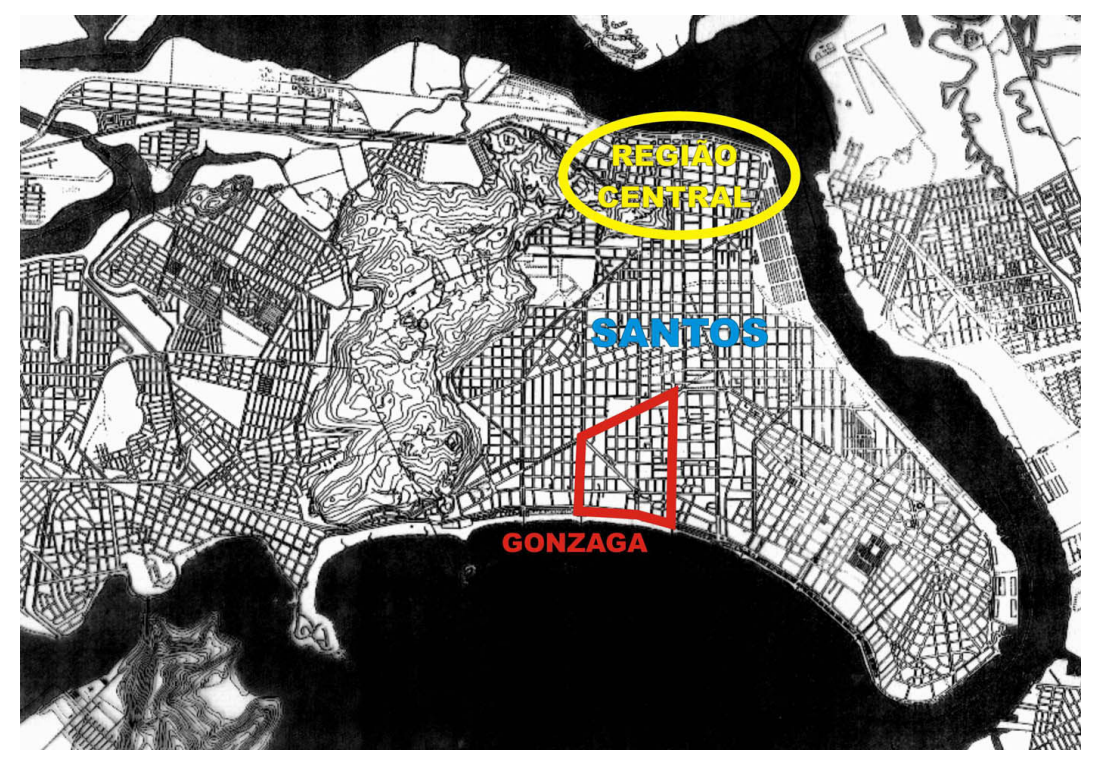

Figura 6 - Localização do bairro do Gonzaga, em relação à região central da Cidade de Santos.

A formação do fenômeno da segregação social no espaço urbano no que concerne às principais metrópoles brasileiras foi abordada em profundidade por VILLAÇA $(1998)^{12}$. Na

\footnotetext{
${ }^{12}$ A definição de segregação espacial apresentada por Villaça (1998: 150) é a que melhor expressa o conceito que adotaremos no presente
} 
obra em referência o autor investigou as formas pelas quais as classes mais privilegiadas, na busca pela melhor localização no espaço urbano, utilizam instrumentos como a informação - técnica ou jornalística, para legitimar junto ao conjunto da sociedade a idéia de que a concentração dos investimentos públicos majoritariamente nas áreas da cidade que ocupam - a orla, no caso da RMBS - é uma coisa perfeitamente natural.

Esse processo, que VILLAÇA identificou como ideologia ${ }^{13}$, na acepção marxista do termo, pode ser reforçado por vários elementos, dentre os quais destaca-se a atuação dos profissionais da área de planejamento urbano, bem como a dos legisladores e administradores públicos municipais.

Essas categorias profissionais e políticas são, em última análise, as responsáveis diretas pela elaboração e implementação do conjunto da regulação que dispõe sobre a organização do espaço das cidades, a qual comumente é denominada legislação urbanística.

Esse instrumental composto primeiramente por códigos sanitários e depois, por leis de uso do solo, códigos de edificações, planos diretores, e outros, parece atuar, não muito raramente, nem exclusivamente, como reforço ao processo de segregação social no espaço das cidades. Isso possivelmente ocorre por meio de dispositivos que acabam por tornar áreas da cidade inacessíveis às camadas de

trabalho, ou seja: "A segregação é um processo necessário à dominação social, econômica e política por meio do espaço".

13 Ver também CHAUY (1980: 32-60) que discutiu os diversos significados do termo ideologia ao longo da história, sobretudo o conceito marxista originalmente exposto na obra de MARX e ENGELS, A Ideologia Alemã - Crítica da Filosofia Alemã mais recente, Vol I, Lisboa, Editorial Presença, $311 \mathrm{p}$. baixa renda da população pela elevação do valor imobiliário nesses locais.

Assim, segundo VILLALAÇA, o aparato técnico e político, nas municipalidades está permanentemente voltado à reprodução de um discurso que distorce a realidade, formando uma falsa consciência de que a legislação urbanística atende aos interesses de toda a sociedade. Essa questão, porém, será aprofundada nos dois últimos capítulos deste trabalho.

Conforme destaca VILLAÇA (1998: 150-151), comentando obra de LOJKINE"14, "As posições que afirmam ser a segregação um produto 'do mecanismo de formação de preços do solo' estão na incômoda posição de ter de demonstrar essa tese, já que é mais provável que a verdade esteja no lado oposto: os preços do solo é que são frutos da segregação". Esta é, pois, a questão central deste trabalho.

Também em VILLAÇA (1998: 148), discutindo-se distintas concepções sobre a questão da segregação no espaço urbano, e citando CASTELLS (1978), encontrou-se a visão daquele autor sobre os fundamentos desta questão:

"'Para Castells (1978, 203 e 204), a distribuição das residências no espaço produz sua diferenciação social e há uma estratificação urbana correspondente a um sistema de estratificação social e, no caso em que a distância social tem uma forte expressão espacial, ocorre a segregação urbana. Segundo ele, 'em um primeiro sentido se

\footnotetext{
${ }^{14}$ LOJKINE (1981), que discutiu as raízes da segregação espacial na sociedade capitalista a partir de uma análise materialista dos vínculos dos grandes grupos industriais e o estado capitalista.
} 
entenderá por segregação urbana a tendência à organização do espaço em zonas de forte homogeneidade social interna $e$ de forte disparidade social entre elas, entendendo-se essa disparidade não só em termos de diferença como também de hierarquia'. Se combinarmos esse pensamento com outro do mesmo autor, teremos a chave para a compreensão do papel da segregação. Diz ele ainda (idem, 141) que 'toda a problemática social tem sua origem entre esses dois termos (natureza e cultura) através do processo dialético mediante o qual uma espécie biológica particular (particular, posto que está dividida em classes), o homem se transforma e transforma seu meio ambiente em sua luta pela vida e pela apropriação diferenciada do produto de seu trabalho' (...)".

Assim, VILLAÇA acompanhou as posições de CASTELLS e sobretudo LOJKINE que não viram relação direta entre legislação urbanística e formação do valor imobiliário como causa da segregação espacial, mas sim como sua decorrência.

Contudo, pode-se encontrar em outros autores interpretações diversas da de VILLAÇA para a questão da segregação. Por exemplo, em MEIRELLES (2000: 523) pode-se ler:

"O controle do uso do solo urbano apresenta-se como das mais prementes necessidades em nossos dias, em que o fenômeno da urbanização dominou todos os povos e degradou as cidades mais humanas, dificultando a vida de seus moradores pela redução dos espaços habitáveis, pela defi- ciência de transportes coletivos, pela insuficiência dos equipamentos comunitários, pela promiscuidade do comércio e da indústria com as áreas de residência e de lazer. Daí o crescente encarecimento dos terrenos para habitação, o que vem impossibilitando sua aquisição pelos menos abastados e exigindo a intervenção do Poder Público no domínio fundiário urbano, para conter a indevida valorização imobiliária, quase sempre resultante dos melhoramentos públicos da área, custeados por todos mas auferidos por alguns. Essa realidade tem reclamado providências estatais específicas para as diferentes áreas urbanas, a fim de compatibilizar sua utilização com as necessidades da coletividade, autorizando imposições urbanísticas de toda ordem, (...).

Mas para a efetividade do controle do uso do solo urbano, após a delimitação da zona urbana, que já analisamos precedentemente, impõese 0 zoneamento da cidade e dos novos núcleos de sua expansão, como veremos a seguir" (grifo do autor).

Portanto, para MEIRELLES a crescente taxa de urbanização e deficiências no controle do uso do solo afiguraram-se como fatores de formação do quadro de degradação das condições de vida em nossas cidades.

No entanto, retrocedendo no tempo, em SIMONSEN ${ }^{15}$ (1941: 14) pode-se ler a seguinte analise, bastante reveladora, quando o autor comparou a situação

\footnotetext{
15 Roberto Simonsen, o mais importante empresário do setor da construção civil, em Santos, na primeira metade século XX, foi precursor e responsável pela introdução dos métodos científicos de gestão, típicos do Taylorismo.
} 
habitacional das classes populares norte-americanas com as nacionais, de então.:

"Se assim é naquele país, o que não acontecerá em outros como o nosso, com populações muito mais pobres?

De fato, o tema da habitação econômica, sendo de universal interesse, apresenta, no entanto, maior acuidade, nos países em que o padrão de vida é reconhecidamente baixo.

Podem aí os arquitetos e construtores se esmerar no estudo de construção, projetada com as máximas tolerâncias admissíveis, quanto a dimensões, materiais e equipamentos utilizados, e não conseguirão obter um tipo de moradia cuja amortização e juros estejam ao alcance da grande massa operária e das classes menos favorecidas".

Dessa forma, o autor estabeleceu como sendo o regime de baixa remuneração da mão-de-obra, que vigora na sociedade brasileira desde a abolição da escravatura, como o verdadeiro responsável pelas más condições de moradia da classe operária, não importa o que se possa fazer, para combatê-las, em termos de flexibilização da regulação urbanística, a que denominou "tolerâncias admissíveis".

Retornando ao presente, em artigo publicado na Folha de São Paulo, em que se discutiu as experiências de enfrentamento das más condições de habitabilidade, no município do Rio de Janeiro, sobretudo as de implementação de programas sociais na "cidade informal", SIRKIS (2002: 3) mencionou a questão fundiária da seguinte forma:

"Um dos principais estímulos à informalidade, sobretudo no caso das zonas norte e oeste do Rio de Janeiro, está na própria legislação urbanística, demasiado burocrática, prolixa e muitas vezes fora da realidade socioeconômica e cultural dessas regiões. O descompasso entre o legal e o real criou uma esquizofrenia cujo resultado foi a explosão da informalidade. Um aspecto crucial da integração desses assentamentos à cidade formal é a criação de regras próprias de uso do solo e de edificabilidade, adaptadas às condições locais e negociadas entre os poderes públicos, as comunidades e os demais interessados.

É preciso repactuar e deixar claro quem pode construir o quê. E de que maneira, onde e sob que condições mínimas de segurança, salubridade e conforto ambiental. Com esse conjunto de ações, poderemos lentamente reverter um dos maiores problemas das nossas cidades e periferias e enfrentar o desafio de fazê-las ambientalmente mais saudáveis e socioeconomicamente menos segregadas e partidas".

Assim, esse autor, ao contrário de MEIRELLES, viu na prolixidade e burocratização da regulação urbanística o agente causador da segregação e em sua alteração o instrumento de transformação dessa realidade, ainda que estivesse se referindo a um tipo específico de regulação, mais próxima da "tolerância" mencionada em SIMONSEN.

Em CYTED - Mejor Habitat y Ciudad para Todos (2001: $67)$, no entanto, encontramos uma analise que sintetizou com perfeição o dualismo de nossas cidades, apontando com clareza as razões da segregação espacial:

"A contradição de base - Na cidade formal existem sistemas para a produção da habitação 
convencional que se desenvolveram de acordo com condições financeiras e técnicas, ou regulamentares, e que não correspondem às necessidades e condições das camadas sociais mais pobres, que constituem uma significativa maioria nas principais cidades da América Latina.

Estas populações têm rendimentos baixos e incertos e estão ligadas ao setor informal e de baixo salário da economia, quando a produção formal de habitações pressupõe salários significativos e garantidos a longo prazo. Por isso a habitação popular nestas cidades insere-se também na economia informal, ou seja, é implantada em solos não destinados à edificação, ou que são ocupados marginalmente e construída pelos próprios meios das comunidades e à medida das suas possibilidades".

Portanto, novamente podemos encontrar, como explicação para o fenômeno da exclusão, a questão dos baixos salários, em oposição às analises que, recorrentemente, atribuem ao trinômio urbanização, regulamentação urbanística e valorização do solo a origem da segregação nas metrópoles brasileiras.

Investigar essa questão no que concerne à cidade de Santos e demais municípios centrais da RMBS é parte fundamental de nosso objetivo. Por razões históricas, as quais não serão aprofundadas, a segregação social no espaço da Baixada Santista tomou impulso e tornou-se mais evidente e mais grave a partir de intensos processos de urbanização que podemos identificar em três fases distintas.
A primeira é a do ciclo do café, com o fim da escravatura, a imigração européia e o advento do trabalho assalariado, na esteira do desenvolvimento vertiginoso dessa atividade agrícola e comercial em São Paulo. Este período estendeuse entre o último quartel do século XIX até a quebra da Bolsa de Valores de Nova lorque, em 1929. Foi a fase em que se consolidou a ligação ferroviária entre o litoral e o interior do estado, com a construção da São Paulo Railway Company - antiga Santos-Jundiaí, depois RFFSA e atualmente RMS Logística - e a implantação dos primeiros trechos de cais do Porto de Santos. Denomina-se esta etapa Período do Café.

A segunda é a etapa que se iniciou com a era Vargas e foi até o final do período da ditadura militar. Foi a fase da industrialização do sudeste e da RMBS, com a inauguração da Via Anchieta, em 1947, implantação do pólo industrial petroquímico e siderúrgico em Cubatão, no pós-guerra, implantação do Corredor de Exportação ${ }^{16}$ e da Margem Esquerda do Porto - em Guarujá (ver Figura 5), na década de 1970, e com o incremento do turismo balneário nas décadas de 50 até 70 . Denomina-se esta etapa Período Desenvolvimentista.

A terceira é a etapa que se iniciou com as crises do petróleo dos anos 70 até o presente ciclo do capitalismo de acumulação flexível, mais conhecido como globalização da economia. É a fase da decadência relativa da região ${ }^{17}$, da

\footnotetext{
${ }^{16}$ Trecho de cais e conjunto de armazéns destinados à exportação de granéis sólidos.

7 Segundo dados da Fundação SEADE, de 1999, a soma do valor adicionado dos municípios da RMBS, que é um bom termômetro da sua atividade econômica, embora venha apresentando uma queda não muito acentuada, desde o final da década de 80 , demonstra a perda da
} 
crise do turismo balneário ${ }^{18}$ e das grandes mudanças provocadas pela privatização da Companhia Siderúrgica Paulista - COSIPA, pelo arrendamento à iniciativa privada de grande parte dos terminais portuários, que levaram a uma brutal queda nos níveis de emprego e renda na RMBS. É o ciclo em que a cidade de Santos passa a apresentar índices demográficos negativos. Por outro lado, as favelas dos municípios centrais da Baixada e os cortiços de Santos apresentaram um crescimento acelerado.

Como a presente pesquisa focalizou a questão da relação entre a legislação urbanística e a valorização imobiliária nas áreas onde se estabeleceu a classe dominante, ou seja, a orla marítima - especialmente no caso de Santos - no Capítulo 4 foi estudado o conjunto desta legislação, tendo como ênfase este município. Neste capítulo procurou-se selecionar elementos que representassem um provável mecanismo de reforço ao processo que provocou o aumento das habitações subnormais em Santos e outras áreas da RMBS.

Esse mecanismo, como se pretende demonstrar, pode ser associado ao aumento da população residente nos cortiços em Santos e ao surgimento de assentamentos irregulares em seus morros, assim como nas áreas mais periféricas da

importância econômica da Baixada Santista relativa a outras regiões do estado, como Campinas e São José dos Campos.

${ }^{8}$ A partir da década de 70 decaíram acentuadamente os níveis de balneabilidade das praias da região, sobretudo nas de Santos, São Vicente, Guarujá e Praia Grande. Tal fenômeno, provocado pelos altos níveis de lançamento de esgoto doméstico, portuário e industrial, afastou parte significativa dos turistas que passou a procurar as praias dos litorais sul e norte. região central da cidade, no final do século XIX e início do $\mathrm{XX}$. Posteriormente, mais precisamente na segunda metade do século $X X$, esse processo provocou o surgimento das favelas em manguezais e de risco geológico, nos morros, bem como o incremento da população residente em cortiços e em loteamentos irregulares.

A investigação mais aprofundada do processo de valorização imobiliária, na orla marítima e áreas contíguas, especialmente no caso de Santos, foi objeto do Capítulo 5. Por razões metodológicas, no presente trabalho aprofundou-se o estudo dos processos de segregação espacial nas duas primeiras etapas acima descritas, pois na terceira fase, a da acumulação flexível, a relação entre legislação urbanística na RMBS e o incremento das habitações subnormais ainda não poderá ser avaliada com a mesma acuidade, em virtude do pouco tempo decorrido das transformações sócio-econômicas do período e da implementação de sua nova legislação. 


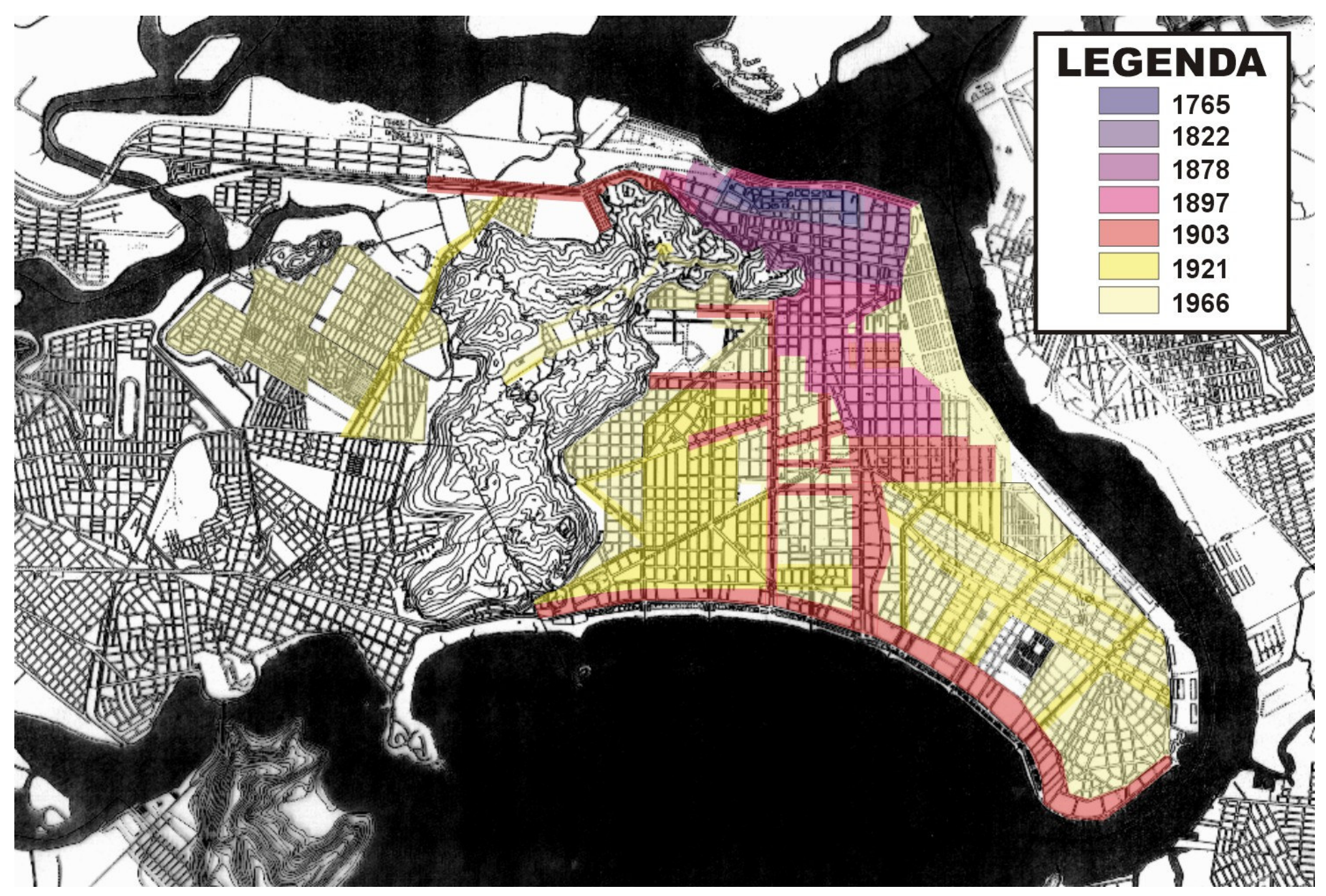

Figura 7 - Cronologia da ocupação da llha de São Vicente, até a década de 1960. Fonte: Mapas históricos apresentados em ANDRADE (1989: 201) e no Anexo 2 - Cartografia Consultada, ao final deste trabalho. 


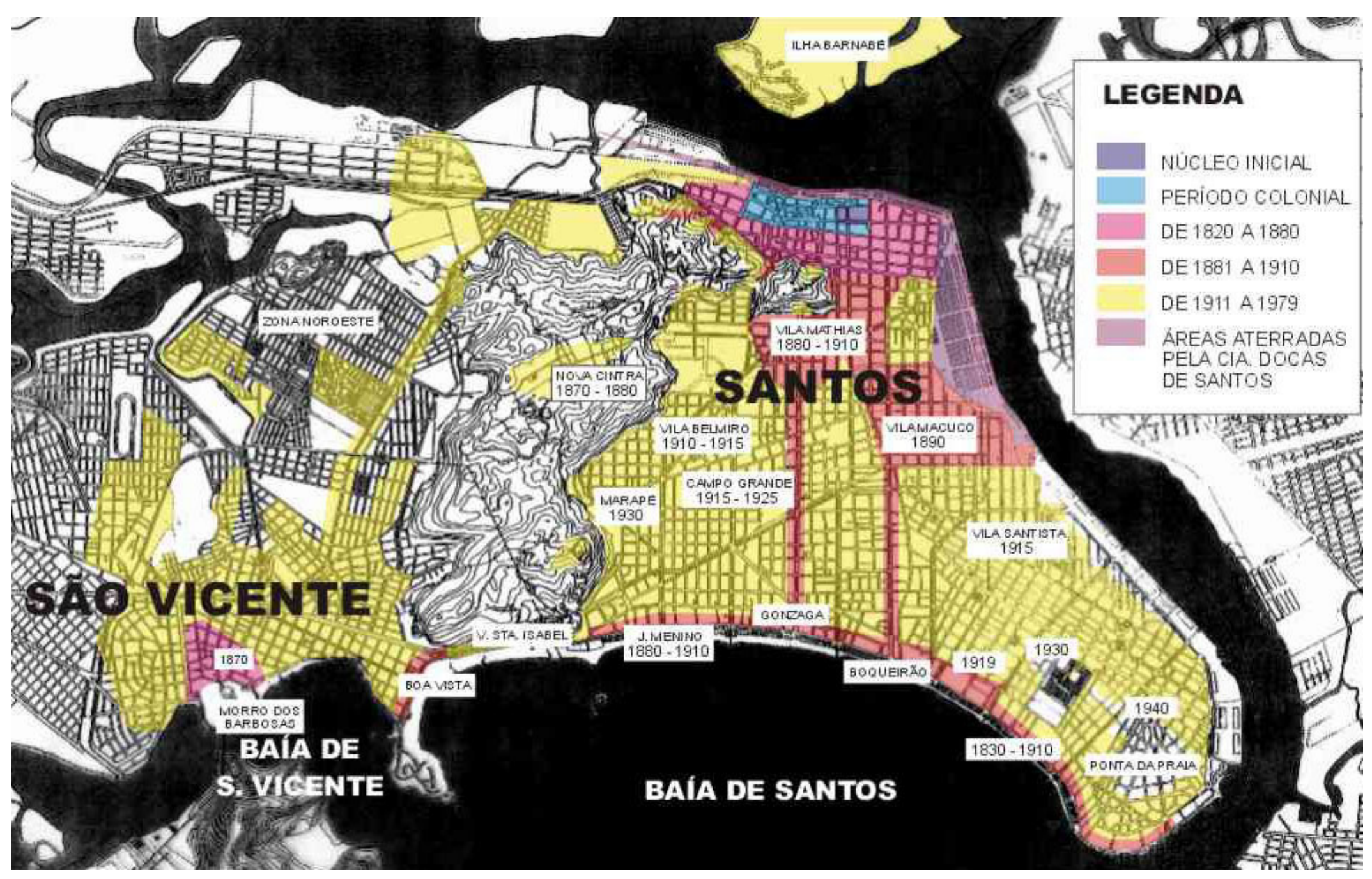

Figura 8 - Cronologia da ocupação da llha de São Vicente, até a década de 1970. Fonte: A Baixada Santista: Aspectos Geográficos, $3^{\circ}$ Volume, dir. Aroldo de Azevedo. São Paulo: EDUSP, 1965, apud ANDRADE (1989) e SEABRA (1979). 


\subsubsection{Período do Café}

"Essa separação ética dos corpos, corpos rebeldes, corpos sãos, preconizava e era simétrica a uma nova divisão geográfica da cidade... a uma discriminação dos espaços"

SEVCENKO (1984: 42), apud LANNA, (1996).

A Vila de Santos originou-se a partir de meados do século $X V I$, a partir da mudança do local de atracação das embarcações na Vila de São Vicente. Inicialmente, o local de atracação era no canal estuarino, a oeste da Ilha, no local hoje denominado Mar Pequeno, no Japuí, bairro continental de São Vicente. Posteriormente, por razões de segurança, os barcos passaram a atracar no local então conhecido como Enguaguaçú, no lagamar junto ao limite atual entre os bairros santistas do Centro e Paquetá.

A primitiva vila, fundada pelo nobre português Braz Cubas, em 1543, originou-se em torno deste atracadouro, no local conhecido como outeiro de Santa Catarina e pouco se desenvolveu durante o primeiro século. Foi tão somente no século XVII que a vila expandiu seus limites, com a ocupação da área do bairro do Valongo, na saída do caminho para São Paulo.

Durante três séculos a Vila de Santos não ultrapassou os limites da área central, entre os bairros do Valongo e Paquetá, entre o lagamar do estuário e o Monte Serrat (ver mapas das Figuras 7 e 8). Em 1838, pela Lei $N^{\circ} 122$, de 26 de janeiro de 1839, Santos foi elevada à categoria de cidade. A esse respeito, podemos ler em ANDRADE (1989:
56), "Alguns autores repetem que a elevação (...) foi uma homenagem à morte de José Bonifácio de Andrada e Silva ${ }^{19}$, ocorrida em Niterói a 6 de junho de 1838. (...) Mas, a realidade é que Santos já progredira o suficiente para merecer o título, conforme mostram-se os documentos".

Foi apenas no final do século XIX que Paquetá e Vila Nova, bairros periféricos ao Centro, passaram a ser ocupados, marcando a primeira grande expansão dos limites da então Cidade de Santos. Quase ao mesmo tempo foram ocupadas as áreas correspondentes aos bairros Vila Mathias e Macuco, e em seguida, iniciou-se a expansão da cidade em direção à orla, com a ocupação dos eixos das avenidas Conselheiro Nébias e Ana Costa, e dos terrenos em frente à praia da Barra.

Como demonstram várias pesquisas concernentes à cidade de Santos, cujos recortes temporais foram o período de expansão entre o final do século XIX e o princípio do século $\mathrm{XX}$, a situação da moradia das populações das classes populares tornou-se gravíssima com o rápido aumento da população, devido ao fluxo imigratório, sobretudo de origem européia. Este fluxo fora motivado pela necessidade de substituir a mão de obra escrava, nas lavouras de café do interior da então Província de São Paulo, em função da abolição do regime escravocrata.

A partir da década de 70 , do século XIX, com a implantação da estrada de ferro ${ }^{20}$ ligando o planalto e com o início da

\footnotetext{
19 José Bonifácio, natural de Santos, cientista e eminente político, foi figura de importância central no Império, tendo sido ministro e tutor de D. Pedro II.

${ }^{20}$ A São Paulo Railway Company foi inaugurada em 16 de fevereiro de
} 1867, sendo uma das primeiras ferrovias do Brasil. Posteriormente 
construção do cais do Porto de Santos, grande parte desta mão de obra fixou-se na cidade, para trabalhar nas obras do porto e na atividade portuária propriamente dita. $\mathrm{Na}$ verdade, desde 1854 Santos tornara-se o "porto do café", com "quase $80 \%$ da movimentação total brasileira" daquele produto (ARAÚJO FILHO, apud ANDRADE, 1989: 101).

Conforme GAMBETA (1984: 19), referindo-se ao final do século XIX em Santos, "Para milhares de trabalhadores, ocupados nas obras do cais e no embarque do café, as perspectivas foram, entretanto, mais sombrias. $O$ incessante aumento da população ${ }^{21}$ esgotou a oferta de moradias dando margem a uma desenfreada especulação imobiliária. Muitas das casas deixadas pelos que fugiam da febre amarela foram transformadas em habitações coletivas. Repartidas em pequenos cubículos, eram subalugadas, por intermediários, a dezenas de famílias imigrantes"

Segundo BONDUKI (1998: 20), "O problema da habitação popular no final do século XIX é concomitante aos primeiros indícios segregação espacial. Se a expansão da cidade e a concentração de trabalhadores ocasionou inúmeros problemas, a segregação social impedia que os diferentes estratos sociais sofressem da mesma maneira os efeitos da

passou a ser denominada Santos-Jundiaí, Rede Ferroviária Federal RFFSA - e atualmente denomina-se RMS Logística.

${ }^{21}$ Segundo o Recenseamento da cidade e município de Santos, de 1913 , a população total que era de 9.871 habitantes em 1872, passou a 88.967 habitantes naquele ano. Deste total, $28,16 \%$ eram estrangeiros, em sua maioria portugueses, espanhóis e italianos. Fonte: MELLO e SACS (1985) apud LANNA (1996: 51).

22 Citando Relatório apresentado ao Dr. Diretor Geral do Serviço Sanitário do Estado de São Paulo, pelo Chefe da Comissão do Serviço Sanitário em Santos, 1895. crise urbana, garantindo à elite áreas de uso exclusivo, livres da deterioração, além de uma apropriação diferenciada dos investimentos públicos".

Nesse período, marcado pelo surgimento da mão de obra assalariada e libertação dos escravos, ocorreu significativa expansão territorial da cidade de Santos ${ }^{23}$, antes restrita ao seu núcleo colonial - correspondente ao atual centro da cidade - deu-se o início da fuga da burguesia, do antigo centro para bairros contíguos como Paquetá e Vila Nova. Em seguida, as camadas de alta renda, sobretudo empresários ligados ao comércio e lavoura de café, passaram a ocupar os eixos das principais vias de ligação com a orla, as avenidas Conselheiro Nébias e Ana Costa, assim como a orla marítima.

Podemos ler em ARAÚJO FILHO (1965: 34), "O início da expansão urbana deu-se com a saída dos mais abastados para as residências, que passaram a ser construídas no Paquetá, ou para as chácaras da Barra, onde se tornaram predominantes até, pelo menos, 1910". Ainda, segundo ANDRADE (1989: 161): "Os mais pobres ocuparam os bairros da Vila Mathias e da Vila Macuco. Fundamental para esta expansão foi a iniciativa oficial, que permitiu a ocupação urbana dessa parte da ilha".

$\mathrm{Na}$ verdade, a ocupação da orla esteve vinculada à implantação do sistema de bondes, inicialmente tracionados por burros, que faziam a ligação entre centro e orla marítima. Da mesma forma que em outras metrópoles brasileiras, em Santos os segmentos empresariais do

\footnotetext{
${ }^{23}$ A história de Santos foi marcada por outras fases de expansão territorial, como ao final do século XVIII, por exemplo, mas nunca em tal proporção, como ocorreu durante o ciclo do café
} 
binômio transportes e promoção imobiliária tinham interesses comuns e alguns empresários, como Mathias Costa $^{24}$, ocupavam-se dos dois ramos de negócio.

Entre o final do século XIX e o princípio do XX, o antigo centro colonial foi quase totalmente reconstruído. Onde só havia, predominantemente, edifícios coloniais, de pavimento único, surgiram edifícios de dois pavimentos, de clara inspiração européia ${ }^{25}$. Era a modernização da cidade inspirada no que ocorria no velho continente.

Conforme apontou SEABRA (1976: 15), "É por essa época que Santos se constitui no recanto de veraneio dos fazendeiros e comerciantes de café. Eles construíram na orla uma segunda residência, os palacetes". Da mesma forma, Guarujá passou a ser bastante procurada pela aristocracia do café. Foi, pois, a descoberta do turismo balneário por santistas e paulistas em geral.

Concomitantemente, os edifícios do Centro e bairros contíguos passaram a ser ocupados por uma rede de atividades de comércio e serviços ligados à atividade portuária. Essas atividades geravam incômodos inaceitáveis para a florescente burguesia, que passou a procurar áreas mais afastadas do Centro, cuja ocupação viabilizou-se pelo

\footnotetext{
${ }^{24}$ Mathias Casimiro Alberto da Costa, português radicado no Brasil, foi comissário de café e sócio da companhia que implantou a primeira linha de bondes, que ligava o Centro à Vila Mathias, bairro que levou seu nome, pois também ali atuava como loteador.

25 Segundo SILVA e GITHAY (1996: 88), em consulta ao recenseamento de 1913, promovido pela Prefeitura de Santos: "Em 1982, havia em Santos 1.407 prédios, enquanto em 1913 o total era de 10.578. As construções de um pavimento passaram de 1.160 para 8.314; de dois pavimentos de 220 para 520; de três pavimentos de 18 para 47 ".
}

trabalho de saneamento e drenagem, implantado pelo Governo da Província, visando combater as renitentes epidemias que assolavam a cidade, na virada do século.

Enquanto isso, conforme apontou LANNA (1996), a classe trabalhadora, constituída, sobretudo por imigrantes portugueses, italianos, espanhóis e escravos recém libertos, passou a ocupar espaços insalubres, nas antigas edificações coloniais, ou barracos de madeira isolados ou enfileirados nos fundos de edifícios comerciais, conhecidos como cortiços.

Outra forma bastante comum de habitação para essa população, principalmente para os solteiros, era a cocheira. Já os portugueses, especialmente os da llha da Madeira, que eram a maioria, preferiram habitar as encostas contíguas ao centro da cidade. Os escravos recém libertos, em grande parte continuaram a viver como sublocatários em áreas de antigos quilombos nos morros e, também, em cortiços $^{26}$.

Acerca desse processo, LANNA (1994: 4) analisou de forma brilhante as raízes da segregação:

"As diferenças sociais visíveis e expressas em homens teoricamente livres e iguais traduziram-se numa necessária reordenação dos espaços. Os critérios de ordem e racionalidade adotados tentaram resolver os impasses desta convivência necessária entre iguais tão socialmente diferentes, separando as funções de trabalho, moradia e lazer e promovendo com isso uma intensa segregação social. Percebe-se neste

\footnotetext{
${ }^{26}$ Desses o mais famoso foi o Quilombo de Quintino de Lacerda, no morro do Jabaquara, que após a libertação dos escravos tornou-se alternativa de residência para a população negra.
} 
movimento a constituição de uma das mais relevantes características das cidades burguesas. Tratava-se de afastar dos olhos aqueles diferentes com quem, inevitavelmente, dadas as condições de produção e reprodução do capitalismo, este espaço urbano tinha que ser compartilhado".

Também em LANNA (1996: 118) pode-se ler, "Se os cortiços eram a forma característica de habitação popular nas grandes cidades brasileiras deste período, em Santos eles primavam pela abundância e precariedade constituindo a forma de alguns, os precários meios de sobrevivência de outros e a causa das péssimas condições de vida da imensa maioria da classe trabalhadora, negra ou branca". Ou seja, a sublocação era a forma como a população pobre residia nos cortiços e em grande parte neles reside até hoje.

A respeito dos cortiços escreveu ANDRADE (1989: 92), "A necessidade de moradias incentivou o reaproveitamento do espaço construído no centro da Cidade. Subdividiram-se as casas, os quartos - qualquer canto servia para alojar pessoas. Custava 2.000 Réis o aluguel de uma vaga, por noite - tudo servia, até lugares vagos dentro das numerosas cocheiras eram utilizados para dormir". Ainda em ANDRADE (1989: 212), lê-se que "A fiscalização sanitária encontrou, certa vez, 186 moradores numa casa do Largo dos Gusmões (hoje Senador Vergueiro), cuja capacidade não bastaria nem para a quarta parte desse número".

$\mathrm{Na}$ verdade, o sítio onde se estabelecera a cidade de Santos era predominantemente alagadiço e o súbito adensamento populacional contribuiu para piorar as condições sanitárias de forma alarmante. As epidemias, que não tinham lugar apenas em Santos, nesta cidade provocaram uma situação peculiar. Por ser "o maior Porto do país, e o escoadouro da riqueza nacional", como apontou LANNA (1996: 22), "O incremento das atividades de exportação e importação e as inúmeras epidemias que aí grassavam, exigiram um conjunto de intervenções urbanísticas com características de plano geral".

Portanto, a situação sanitária em Santos preocupava toda a Província, pois prejudicava enormemente o comércio do café. Os grandes investimentos feitos na construção do cais estariam condenados, caso não se controlasse as epidemias que retinham embarcações durante meses na barra. A má fama da cidade chegou rapidamente ao exterior, a ponto de afixarem-se avisos alertando quanto aos riscos de atracar em Santos, em portos europeus.

Em LAMBERG (1896), podemos ter a real medida da situação: "Da cidade em si, a única coisa interessante que há a dizer é que, a partir do mês de novembro até fins de abril, transforma-se em vasto cemitério internacional", apud ANDRADE (1989: 70).

Segundo GUIMARÃES (1996), "A situação era calamitosa. Entre 1890 e 1900 morreram vítimas das epidemias 22.588 pessoas. Esse número correspondia a mais ou menos metade da população da cidade. O estado de calamidade fazia com que os navios que atracassem no porto tivessem que fazer quarentena afetando a principal fonte de riqueza da cidade - o comércio", apud LANNA, (1996: 69).

A esse respeito informou ANDRADE (1989: 74) que em um único ano, o de 1892, morreram 2.695 habitantes, em 
Santos $^{27}$. As medidas adotadas pelo governo da Província foram enérgicas. Segundo ANDRADE (1989: 95), "Santos e São Paulo eram mais do que nunca cidades ligadas por interesses comuns".

Era, pois, imperativo encontrar-se uma solução para a grave situação sanitária de Santos. Foi, então, nomeada uma Comissão Sanitária, que organizou um serviço médico municipal, determinou a construção de um hospital de isolamento, um alojamento para imigrantes, um novo matadouro, a limpeza das praias e ruas da cidade (ANDRADE, 1989: 173).

Ao mesmo tempo iniciou-se uma implacável ação de demolição de barracos e cortiços, permeada de ações brutais, que despertaram grande revolta na população de baixa renda, à qual não se apresentava outra alternativa habitacional. Embora o principal foco de disseminação das doenças, como se verificou mais tarde, fosse a falta de saneamento, os cortiços, cocheiras e demais habitações insalubres foram vistas como as razões para o infortúnio da cidade.

Em ofício da Comissão de Vigilância Sanitária de Santos, de 17 de março de 1889, ao presidente da província, em que o problema dos cortiços figura como a primeira, dentre oito causas principais das epidemias, pode-se ler, "O grande número de cortiços no mais deplorável estado, tornando-se quase completamente inabitáveis (...)", apud ANDRADE (1989: 87).

\footnotetext{
27 Dentre os principais surtos epidêmicos do período, os de maior morbidade foram os de febre amarela, tuberculose, impaludismo e varíola (ANDRADE, 1989: 75).
}

A ação precípua da Comissão Sanitária, ligada à Secretaria dos Negócios do Interior, nomeada no início da década de 1890, foi a de polícia sanitária, com carta branca para desalojar famílias, queimar seus pertences e toda sorte de arbitrariedades, que apavoravam a população.

Ao mesmo tempo foi criada a Comissão de Saneamento, ligada à Secretaria da Agricultura, que veio a desenvolver um plano de urbanização para a grande baixada que se estendia entre o núcleo ocupado da cidade e as praias, abrindo canais, drenando charcos e possibilitando sua ocupação pela burguesia florescente.

Como ressaltou LANNA (1996: 72-73), "Em Santos, como no Rio de Janeiro de Pereira Passos, a remodelação do porto veio acompanhada de uma política de intervenção urbana com forte cunho sanitarista e que acabava por excluir a população pobre". Mais adiante LANNA (1984: 42), citando SEVCENKO (1984), complementou: "A população assistia a fúria avassaladora deste processo de segregação. 'Essa separação ética de corpos, corpos rebeldes, corpos doentes, corpos sãos, preconizara a era simétrica a uma nova divisão geográfica da cidade... a uma discriminação dos espaços".

Em BONDUKI (1998: 34) encontra-se esta citação de VEIGA (1984), que dá a real medida do pensamento higienista da época:

"Os higienistas enxergaram na própria moradia a origem dos males e contra ela voltaram suas armas: 'São as casas imundas o berço do vicio e do crime' (VEIGA 1894:82). Por fim, concebiam o trabalhador pobre como um ser ignorante que, sem moral, higiene e bons costumes, podia tornar-se um ser politicamente perigoso: ' $\mathrm{O}$ socialismo destruidor e pernicioso para o 
progresso de uma nação encontra, nesses centros das grandes cidades, uma atmosfera favorável para seu engrandecimento' (VEIGA 1894:82). Os trabalhadores necessitavam ser vigiados, controlados e reeducados em seus hábitos de morar. Essa visão moralista, que orientou a intervenção estatal em São Paulo, iria perdurar até a década de 1940".

Também em BONDUKI (1998: 39) pode-se ler:

"É coerente com o enfoque higienista a atenção dedicada pelo poder publico aos cortiços e outras habitações coletivas, pois a superlotação, uso comum de sanitários e ausência de saneamento criavam condições para a propagação de doenças contagiosas. No entanto, o fato de o higienismo ter transformado suas posturas em leis não significava que essas normas eram obedecidas na pratica. Pelo contrário, já no final do século XIX começou a se ampliar o fosso entre os padrões legais e a atividade de construção de moradias populares, empreendida quase sempre por particulares que visavam obter delas rendimentos por meio da cobrança de aluguel".

Várias comissões nomeadas pelo Estado estudaram a questão do saneamento de Santos. Dentre elas, conforme ANDRADE (1989: 175), "a Comissão Ferraz (1892 a 1894) fez um levantamento da planta de Santos para o engenheiro Fuertes, um norte-americano que passou por Santos rapidamente e apresentou um projeto em 1894. Outra foi a Comissão Cochrane que sugeriu o aproveitamento melhorado da rede de esgoto existente. A Comissão Lisboa, em 1895, propôs o sistema de separador parcial e, em 1901, adotou o sistema de separador absoluto",28.

Pode-se, ainda, citar a participação do engenheiro José Rebouças na concepção do plano para Santos, que deixou desgastado a chefia da Comissão de Saneamento. No entanto, o projeto escolhido pelo Estado foi o do engenheiro sanitarista fluminense Francisco Saturnino de Brito. Podemos ler em ANDRADE (1989: 175), que o plano de Saturnino "previa a divisão da cidade em distritos; o sistema de separador absoluto e o esgotamento dos despejos pelo sistema de elevação ${ }^{29}$, sendo os morros acompanhados por um canal de contorno; o destino dos despejos seria fora da ilha, no continente, levados por canos que atravessariam o mar e chegariam à ponta do Itaipu"30.

Saturnino propôs uma rede de canais de drenagem, para recolher as águas dos rios que cortavam a planície da ilha $^{31}$. Os canais, em número de nove (ver Figura 9),

${ }^{28} \mathrm{O}$ sistema de separação absoluta consiste na total independência entre as redes de drenagem das águas pluviais e as de esgotamento sanitário.

${ }^{29}$ Devido à reduzida diferença de cota nas áreas de planície na ilha, era necessário elevar o esgoto para que este fosse conduzido por gravidade até a próxima estação, e depois até o destino final. Ainda hoje podem ser encontradas algumas dessas estações originais do Plano de Saturnino de Brito em Santos e em São Vicente.

${ }^{30}$ A ponta do Itaipu localiza-se no município de Praia Grande, na divisa com a área continental do município de São Vicente, próxima ao bairro do Japuí, que é ligado à ilha pela Ponte Pênsil, construída originalmente para a condução, por meio de tubulações, do esgoto ao seu destino final, no oceano.

${ }^{31}$ Segundo ANDRADE (1989: 178), "na parte que se refere aos canais de drenagem, não foi idéia original de Saturnino". A autora cita AGUIAR, Francisco X. da Costa, na obra Memória, de 1809, em que este preconizava a necessidade de "continuar a Villa, pelas grandes e 
cortariam a ilha, no lado de Santos, de ponta a ponta. Os canais, que acabaram por estruturar todo o sistema viário da área leste da ilha, recebiam a contribuição de galerias de drenagem de águas pluviais.

Segundo ANDRADE (1989: 175 A), "Os canais ocupariam o espaço central das avenidas facilitando a circulação e o arejamento urbano. Árvores seriam plantadas nas calçadas laterais, formando paisagem urbana amena com espaços de circulação para pedestres e veículos". Ainda, segundo ANDRADE, "uniam-se, desta forma, três idéias caras à época: a higiene, o espaço público e a beleza urbana".

Todavia, em ANDRADE (1898: 183) ressaltou-se o fato de que o plano de Saturnino apresentado à Câmara de Santos foi, por esta, recusado. Na verdade, Saturnino enfrentou fortes resistências em nível local.

Segundo LANNA (1994), esse processo de higienização da cidade não foi pacífico, tendo o plano de Saturnino enfrentado a resistência também dos setores populares: "Verdadeiras guerras contra os cortiços foram travadas. As demolições e reformas impostas pelas autoridades implicavam num reordenamento da casa e da rua. Esvaziar as ruas e desadensar as casas eram as palavras de ordem. A população reagiu às imposições deste novo modelo. Seja permanecendo nas ruas, seja recolocando seus padrões precários de moradia mais distantes dos olhares dos inspetores, seja apelando para construções clandestinas chamadas chalés que indicavam um vigor dos novos padrões de privacidade".

desafogadas planícies" com o esgotamento das "muitas águas" por meio de uma "vala real".
Ressaltamos que, além da força bruta que arrancava famílias de seus lares pela ação da polícia sanitária, o próprio plano de saneamento e urbanização, a cargo de Saturnino de Brito, representou um forte fator de exclusão espacial. Como apontou LANNA (1996: 75), essa questão já preocupava Saturnino:

"Como fazer com que a população pudesse usufruir os melhoramentos sem ser expulsa, pelos especuladores e intermediários desonestos, era um problema recorrente no pensamento de Brito. Entretanto, se esta preocupação o fazia mais cuidadoso quanto às solicitações de demolições, nunca o impediu de fazelas quando as julgava estritamente necessárias. A preocupação social, assim como a dimensão estética estavam subordinadas à imperiosidade técnica".

$\mathrm{Na}$ realidade, Saturnino imaginava que a área do plano pudesse ter espaço para todos. Em sua concepção vilas operárias ou "familistérios" viriam a abrigar as famílias dos trabalhadores com segurança e livres de contaminação. O que se viu foi o oposto. Loteamentos, como o que originou o bairro da Vila Belmiro, aprovados pelo governo municipal com incentivos fiscais, em função dedestinarem-se ao operariado, a pricípio, tiveram sua finalidade desvirtuada e passaram a servir de moradia para a classe média ${ }^{32}$.

Afinal, não havia alternativa de financiamento habitacional, acessível para as classes de baixa renda. Além disso, o

32 O loteamento recebeu esse nome em homenagem ao seu empreendedor, o segundo prefeito eleito de Santos, Belmiro Ribeiro de Moraes e Silva, que era vice de Carlos Augusto Vasconcelos Tavares o primeiro eleito - que se licenciou, por razões de saúde, em 1910. Posteriormente, Belmiro foi eleito em 1911, para um mandato que durou até 1914. Mais tarde, em 1917, Belmiro foi reeleito e governou até 1920, tendo sido o prefeito que mais tempo permaneceu no cargo, em Santos. 
valor dos terrenos nas áreas recém drenadas pelo plano de Saturnino rapidamente subiu. A este respeito LANNA (1996: 98-99) destacou que,

"Os anos 90 do século passado marcaram o início da ação de desadensamento do centro e o aparecimento dos primeiros loteamentos previstos para a classe trabalhadora. Loteamentos estes de iniciativa privada e aliados à expansão da rede de transportes urbanos que era explorada pelos proprietários dos terrenos. Evidentemente a população moradora dos cortiços nunca, ou mais raramente, teve condições financeiras de adquirir estes lotes que foram comprados por uma crescente camada urbana de servidores públicos e empregados qualificados muitos deles pertencentes aos quadros da Companhia Docas ${ }^{33 "}$.

Apesar de excludente, não se pode negar a importânciada obra de Saturnino, em nível nacional. Acerca desta importância ANDRADE (1991: 57) afirmou que,

"O trabalho que Saturnino de Brito realiza para a cidade de Santos, como engenheiro-chefe de sua Comissão de Saneamento, nomeado pelo Governo do Estado de São Paulo, é, sem dúvida, sua mais importante obra construída. É também, como afirma o próprio filho do sanitarista, 'a obra de maior significado na constituição da escola brasileira de engenharia sanitária, porque nela se elabora concretamente a diretriz técnica nacional relativa à construção de esgotos'34. A

${ }^{33}$ A Companhia Docas de Santos era a empresa que administrava o porto, por concessão federal que encerrou-se na década de 70 do século XX.

${ }^{34}$ Citando BRITO (1943) experimentação contida nos projetos de expansão e saneamento de Santos foi a responsável, como ainda observa o eng. Saturnino de Brito Filho, por modelar a técnica apropriada ao nosso meio. Diversos aparelhos e processos inovadores foram desenvolvidos por Saturnino de Brito na construção dos esgotos de Santos, destacando-se o emprego de concreto armado nos canais de drenagem das águas pluviais, a adoção de estações elevatórias distritais, além de inúmeras peças para as instalações domiciliares. Também no campo administrativo e econômico os trabalhos de Brito para Santos inauguraram novos procedimentos no sentido de racionalizar operações e obras. Mas o aspecto de sua obra que nos parece o principal é o traçado do plano de expansão da cidade. As realizações de Saturnino de Brito deram origem a uma nova cidade com um desenho extremamente moderno para a época, aproximando a paisagem urbana santista daquela de cidades européias".

Complementarmente às ações profiláticas da polícia sanitária e à implantação do plano de Saturnino, surgiram as primeiras leis urbanísticas de caráter higienista. Como ressalta GAMBETA (1984: 22-23), "Os higienistas foram fortalecidos pelo Código Sanitário do Estado e pelo novo Código de Posturas santista, de 1897. Em prol da saúde pública ficava prejudicada a inviolabilidade do domicílio. A liberdade individual não poderia, se dizia, pôr em risco a saúde coletiva". 


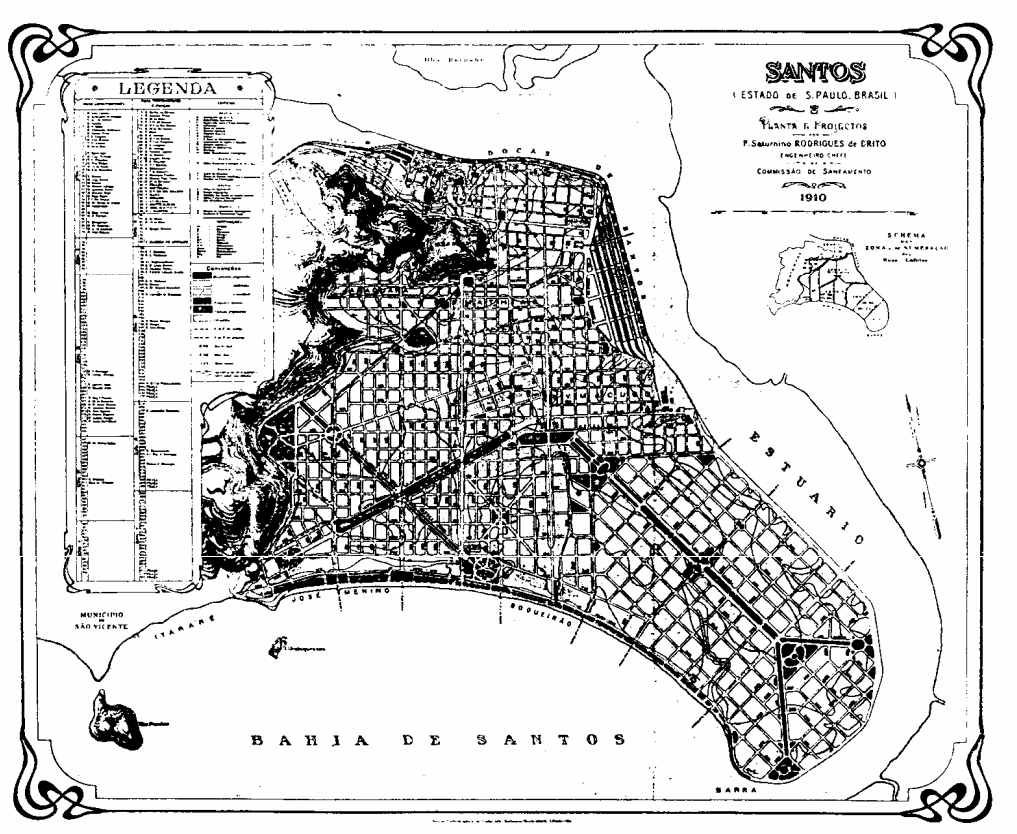

Figura 9 - Plano de Santos elaborado por Saturnino de Brito. Fonte: ANDRADE (1991: 60).

Estas leis foram embriões dos códigos de obras e zoneamento de uso do solo que surgiram no século seguinte, e que serão objeto de estudo no Capítulo 4. Num primeiro momento elas legitimaram as ações de força da polícia sanitária, mas também assentaram as bases para uma série de "intervenções" na forma de parcelar o solo e edificar, que viriam a tornar as áreas drenadas pelo plano de Saturnino territórios economicamente inacessíveis às classes de baixa renda.

Mas onde habitavam as famílias de baixa renda, expulsas das toscas construções sub-locadas e os novos imigrantes que embora em menor número continuaram a chegar à cidade? Onde foram construir suas moradias longe dos olhares dos inspetores sanitários? Os estudos da época, sobretudo os referidos no presente trabalho, revelam algumas das principais alternativas encontradas.

Em primeiro lugar, apesar das ações da polícia sanitária, os cortiços não foram totalmente erradicados e de fato estão presentes até hoje, em áreas contíguas ao centro de Santos $^{35}$. Na verdade, os cortiços ressurgiram na periferia do sítio original da cidade colonial ${ }^{36}$ (ver Figura 10). De forma encadeada a esse processo, os habitantes das várzeas mais distantes também foram expulsos de seus sítios.

Como se pode ler em IPT (1979: 109), "Nesse período, as classes médias nascentes passaram a habitar os bairros do Gonzaga, Boqueirão e Vila Mathias, determinando a mudança de seus primeiros habitantes de menor poder aquisitivo, para outros trechos da ilha; o que constituiu um dos primeiros processos de expulsão e substituição de população em Santos".

Os morros tornaram-se uma das alternativas de localização habitacional, não apenas para os escravos recém libertos, mas também para aquela parcela de imigrantes não absorvida pela lavoura cafeeira, que ficou em Santos. Também em IPT (1979: 109) observou-se: "A proximidade

35 O surgimento de cortiços praticamente não ocorreu nos demais municípios da Baixada, pois nestes não houve, com a mesma intensidade, o processo de adensamento e, posteriormente, de substituição da população de classe média e alta residente nos bairros próximos ao centro por populações de baixa renda.

${ }^{36}$ Área atualmente correspondente aos bairros de Vila Mathias e Vila Nova. 
dos Morros dos principais pólos de trabalho - centro comercial e cais do porto -, bem como a falta de opção de moradia a custo aceitável, dirigiu a população operária nascente para as encostas dos morros, então abandonadas como áreas inúteis de cultivo".

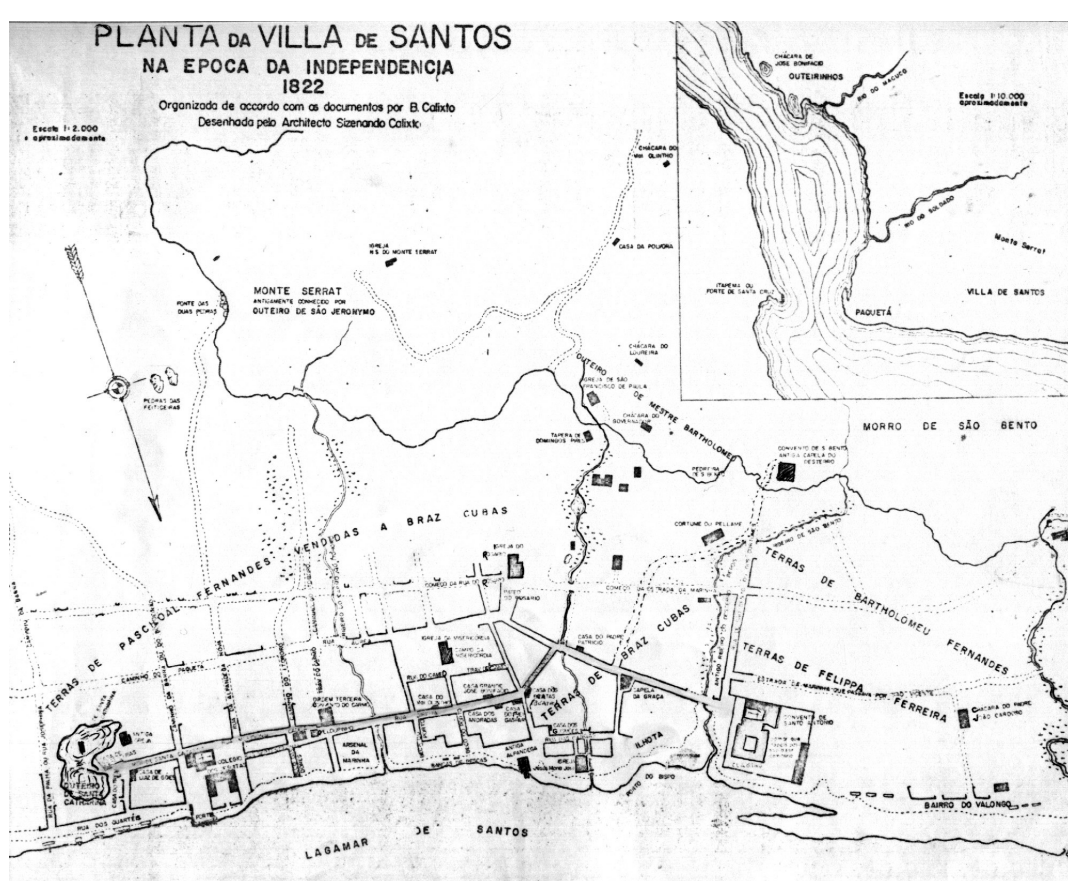

Figura 10 - Vila de Santos em 1822. O perímetro urbano é equivalente à área do Centro atual, no quadrilátero que vai do estuário à rua João Pessoa e da rua da Constituição ao Largo Marquês do Monte Alegre. Fonte: ANDRADE (1989).

Outra conseqüência da expulsão da população de baixa renda para fora dos limites da cidade foi o surgimento de assentamentos do lado oposto do estuário, na llha de Santo
Amaro, no atual município do Guarujá. Segundo levantamento da Empresa de Urbanização de Guarujá EMURG -, o assentamento de Conceiçãozinha, que data de 1907, foi provavelmente a primeira favela da Baixada, com construções em palafitas sobre a maré, em área que hoje é destinada para a expansão do porto, na margem esquerda. Sua origem, segundo SERRANO (1991), foi com o estabelecimento de famílias de pescadores que não possuíam recursos para residir na llha de São Vicente.

A tipologia habitacional das classes populares por excelência, talvez a mais utilizada na virada do século XIX para o XX, foi a habitação em construções de madeira que ficaram conhecidas como "chalés", moradia típica da classe operária santista. Estes chalés podiam ser vistos nas encostas dos morros próximos ao centro da cidade, como Monte Serrat, São Bento, Fontana, Bufo, Pacheco, Jabaquara e, também, em bairros mais afastados como a Vila Macuco, que viria a se tornar o grande bairro popular da cidade na primeira metade deste século.

\section{Segundo CALDATTO (1998: 39),}

"o chalé, (...), aparece no cenário urbano de Santos, no final do século XIX, como obra da população de baixa renda para solucionar o problema habitacional que atingia milhares de trabalhadores. A proibição dos cortiços, vistos como uma ameaça à saúde pública, nesse momento, levou boa parte de seus moradores a se deslocarem para outros locais do território, preferencialmente onde o solo urbano tivesse pouco valor. lam se arranjando dentro do possível, cada um a seu modo, na luta para conseguir um abrigo. A moradia de madeira, obra de baixo custo e rápida execução, 
passou a ser a forma encontrada pelos excluídos para a solução imediata do seu problema".

Ainda, segundo CALDATTO (1989: 136), a localização dos chalés de madeira "foi disseminada no tecido urbano de Santos". Os chalés poderiam ser encontrados em bairros como Marapé, Jabaquara, Campo Grande, Encruzilhada, Macuco, Estuário, Embaré, Ponta da Praia e nas encostas dos morros (ver Figura 11). Isto se devia ao fato de que estes bairros eram constituídos de vastas áreas planas e desocupadas, cujos "terrenos abundantes e baratos eram

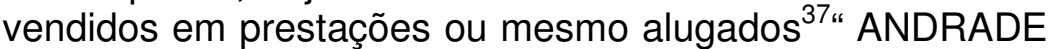
(1989: 221).

Em CALDATTO (1998: 116 a 118) pode-se encontrar três plantas da cidade com a distribuição territorial dos chalés, referentes a processos de pedido de aprovação em tramitação na Câmara Municipal. As plantas referem-se, respectivamente aos períodos que vão de 1890 a 1895, 1895 a 1900 e 1900 a 1910. Ao analisar-se essas plantas, pode-se notar que as localizações predominantes nesses períodos eram os bairros periféricos ao Centro, tais como Macuco, Jabaquara e Vila Mathias, em que a população de alta renda não se estabeleceu. No Paquetá e Vila Nova, também bairros periféricos ao Centro, porém localizações preferidas pela burguesia que começava a deixar a região central, era mais rara a ocorrência de chalés.

Também, sobre os chalés, pode-se ler em ANDRADE (1989: 212),

${ }^{37} \mathrm{O}$ aluguel de terrenos para a construção, de forma clandestina, de moradias por famílias de baixa renda, é uma forma tradicional de locação e de parcelamento irregular do solo, tradicional em Santos, sobretudo na região dos morros, conhecida como "aluguel de chão".
"Assim, os excedentes populacionais pobres, expulsos do centro pelas péssimas condições de moradia ou pela força da Política, foram para os arrabaldes da cidade.

Foram os seguintes os fatores de expansão dos chalés como moradia popular: necessidade premente de moradia; alto custo dos aluguéis no Centro; pressão da Comissão Sanitária contra os cortiços por causa das epidemias; não execução dos planos de habitação popular; mão-de-obra barata e costume do mutirão; relevo da planície; existência da madeira trazida ou pela ferrovia ou por navios; presença das linhas de bonde, ligeiros e até baratos; e idéia de construir uma casa de madeira: o chalé".

Ainda em ANDRADE (1989: 213 e 214) pode-se conhecer algo do processo de construção dos chalés, como a origem da madeira e a organização de mutirões, preferencialmente aos fins-de-semana, para fugir aos olhos da fiscalização. A autora escreveu: "Faziam-se as refeições no local e trabalhava-se à noite, se necessário. Os serviços eram concomitantes, o que exigia boa coordenação". E mais adiante, "Na segunda-feira, mais um chalé pronto, mais uma família abrigada: as sensações de posse, de proteção, a vitória do trabalho contra o desabrigo, o seguro contra a indesejável promiscuidade dos cortiços".

Em seguida, ANDRADE afirmou: "Ainda existem muitos chalés - em Santos, S. Vicente, Cubatão, Guarujá (não os da fundação, todos demolidos) - referindo-se aos chalés de alta renda da Vila Balneária -, Praia Grande, Bertioga ... Modificados, eles atestam um passados de pobreza que contrastou fortemente com a riqueza que também dominou a Baixada Santista". Na realidade, o chalé de madeira foi 
uma tipologia habitacional popular que extrapolou os limites de Santos, alcançando a maior parte das cidades da região.

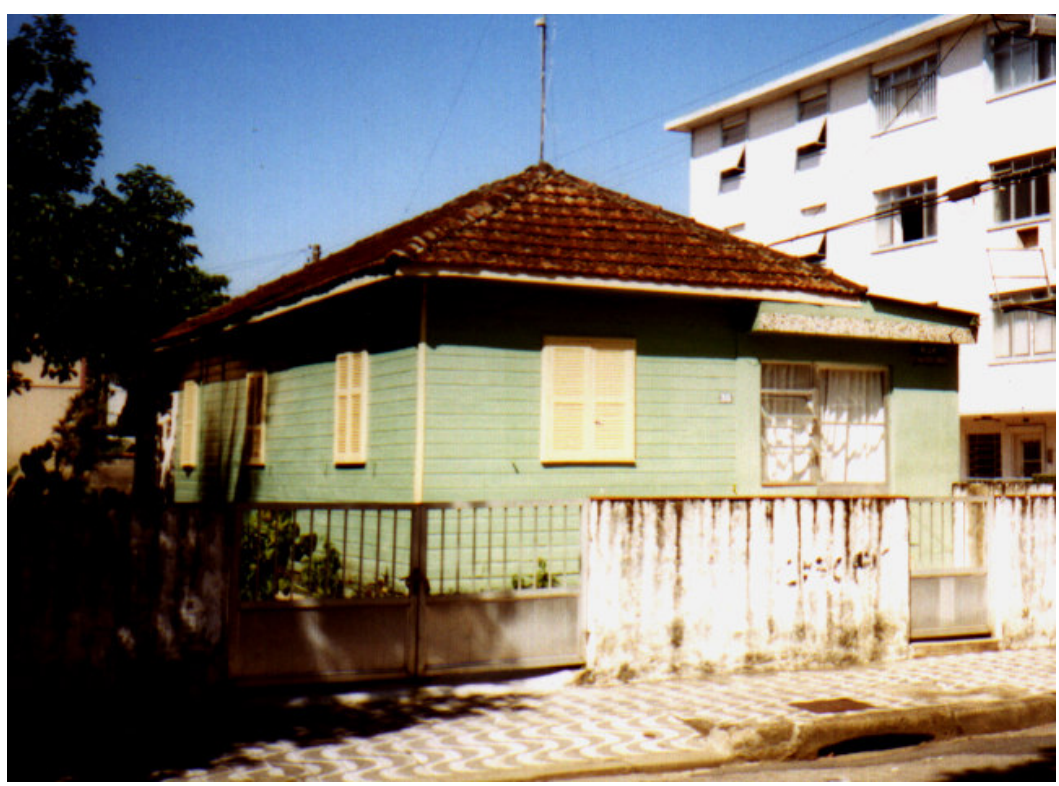

Figura 11 - Chalé de madeira, com acréscimo em alvenaria - à direita - localizado à rua Ciro de Ataíde Carneiro, no bairro Ponta da Praia. Foto do autor, 2002.

Portanto, esses foram os territórios e tipologias em que as classes de baixa renda se estabeleceram, na passagem para o século XX: cortiços e chalés nas áreas periféricas ao centro, encostas sujeitas a deslizamentos, que de fato marcaram com várias tragédias a história da cidade $^{38}$, e

38 Segundo SERRANO (1984: 29), "Sem um programa paralelo de construção de habitações, os trabalhadores e suas famílias foram expulsos para os morros e as várzeas do Macuco e Vila Mathias, onde construíram os barracos tão precários quanto aqueles em que áreas sujeitas à ação das marés, ainda não incorporadas ao plano de Saturnino. LANNA (1994: 17) resumiu lapidarmente o período: "Desta cidade estavam excluídos a maioria dos trabalhadores e, sobretudo, negada a forma de nela viver que eles haviam conhecido".

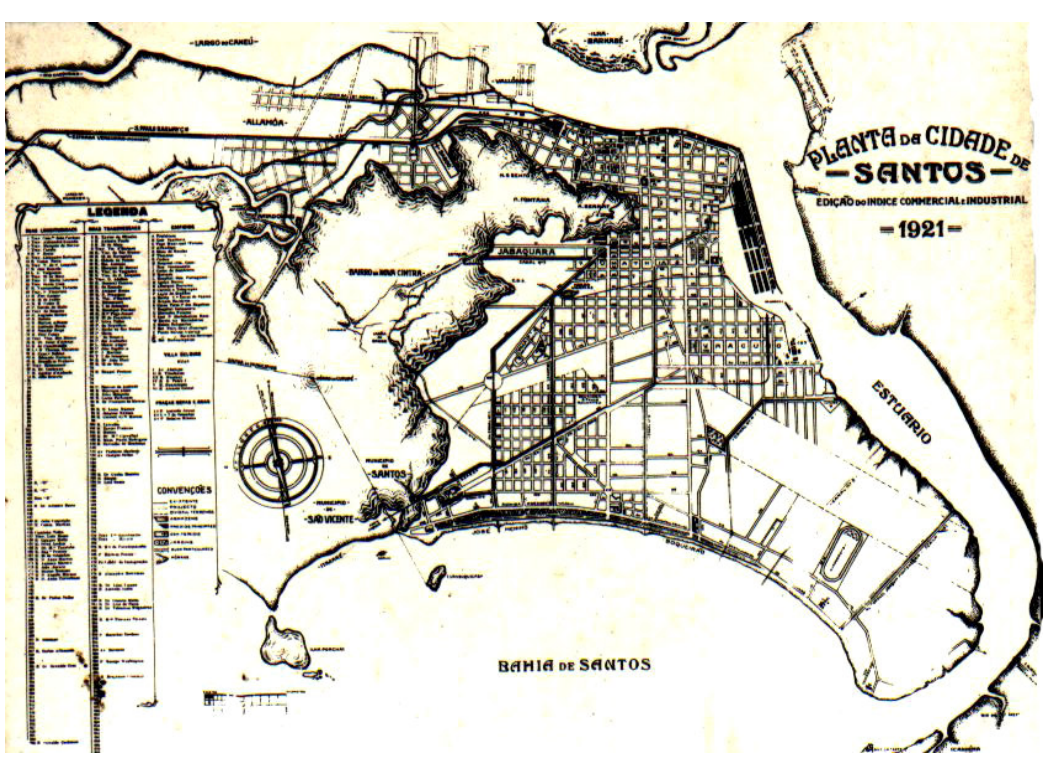

Figura 12 - Planta de Santos, em 1921, após o primeiro período de expansão devido à implantação do Plano de Saneamento. Fonte: ASSECOB (1984).

Porém, tentativas tímidas e infrutíferas foram feitas, no final do século XIX e início do século XX, visando enfrentar a

residiam". Mais adiante, o autor lembrou o escorregamento do Monte Serrat, morro junto ao centro da cidade, em que "cerca de uma centena de pessoas morreram e foi destruída uma ala do Hospital Santa Casa (...). Em 6 de fevereiro de 1929, de novo, o Monte Serrat sofreu desmoronamento (...) não houve vítimas a lamentar". 
nascente questão das más condições habitacionais da classe operária. Destas pode-se citar sobretudo duas, no caso de Santos.

A primeira, prevista desde a sanção do Código de Posturas de 1897, foi a regulamentação dos "familistérios", os quais consistiriam em habitações coletivas para as famílias dos trabalhadores, com um mínimo de organização e salubridade, dentro dos padrões higienistas. Ou seja, procurava-se tornar os cortiços alternativa de habitação popular em condições sanitárias aceitáveis. Porém, as exigências legais certamente elevavam os custos de produção destas moradias, que sem apoio governamental, ou qualquer forma de financiamento eficaz destinado às populações de baixa renda, não vingaram como tipologia alternativa às centenas de cortiços espalhados pela cidade.

A segunda, possibilitada por leis municipais que concediam incentivos especiais, previa a implantação de conjuntos de moradias operárias, nos novos bairros que surgiram a partir da implantação do plano de Saturnino e da extensão das linhas de bonde ${ }^{39}$. O caso mais notável constituiu-se no da Vila Belmiro, que se tornou um bairro de Santos. O empreendedor imobiliário e prefeito Belmiro Ribeiro, de quem o bairro levou o nome, recebeu "favores" especiais da municipalidade, como isenção de impostos, para implantar o conjunto de moradias. Mas o custo inacessível das mesmas, aos operários que não dispunham de "favores" equivalentes aos concedidos ao promotor da obra, como financiamento público, não permitiu a fixação da população

${ }^{39}$ A Company of Santos Improvement, concessionária dos serviços de bonde em Santos, esteve freqüentemente vinculada à promoção imobiliária nos loteamentos abertos na "nova" cidade que se descortinava em direção à orla. de baixa renda, e fez com que o bairro fosse ocupado pela crescente classe média santista, como ocorre até hoje.

Em artigo publicado por SIMONSEN (1941: 24), em que este reproduzia sua intervenção na conferência Jornada da Habitação Econômica, pode-se ler:

"Dia a dia mais se verifica, nas grandes cidades, que não é possível obter, da iniciativa particular, a construção de vivendas populares em número suficiente para as necessidades das populações.

No regime econômico em que vivemos, os capitais procuram lucros ou remunerações que não podem ser dados pelos parcos orçamentos das famílias operárias e das classes menos favorecidas.

Tentar deslocar o problema para todo e qualquer chefe de família, é criar, muita vez, uma situação insuportável para os proprietários, que ficam escravizados a dívidas cujos serviços, absorvendo proporção muito elevada de seus rendimentos, sacrificam a satisfação de outras necessidades da vida.

A casa individual no regime normal, só deve ser proporcionada àqueles que têm recursos suficientes para arcar com o ônus criado".

A respeito da ação governamental no enfrentamento da questão habitacional, escreveu ANDRADE (1989: 215): "As autoridades constituídas ignoraram oficialmente, o mais que puderam, o problema habitacional que empurrou os excedentes populacionais do antigo Centro para as áreas periféricas (...)".

Em artigo do jornal Gazeta do Povo, publicado na primeira página, da edição de 30 de março de 1918, pode-se 
perceber em que medida as tentativas de formular alternativas de moradia para a população de baixa renda já encontravam obstáculos por falta de condições de financiamento e da dificuldade de reprodução da força de trabalho desta classe, tema que abordaremos com maior profundidade na seqüência deste trabalho. $\mathrm{O}$ aludido artigo, em determinado ponto revela que "(...) as 'vilas' sempre são mais custosas, e conseqüentemente dão muito maiores lucros aos que dela se encarregam".

Na verdade, as "vilas", conjuntos de moradias conjugadas que representaram a tipologia habitacional dominante nos bairros mais próximos ao centro no início do século $X X$, foram alternativas que esbarravam no custo elevado e na percepção, por parte dos empresários, de que com sua construção poderiam realizar bons lucros. Isto a despeito, na maioria das vezes, de contarem com incentivos fiscais, como nos empreendimentos de Belmiro Ribeiro e de Mathias Costa.

Portanto, apesar de contarem com subsídio, por terem vingado dentro do mercado formal de construção sem ações efetivas de financiamento, por parte dos agentes públicos, as construções de moradias em vilas acabaram por atender uma certa faixa da população de renda média, excluindo as camadas de baixa renda.

Contudo, os empreendedores imobiliários desse segmento acabaram por incorporar em seu lucro a fatia correspondente ao subsídio, apesar de que a legislação específica da época, como será visto adiante, procurava estabelecer certas regras de parcelamento e facilitação da compra das unidades, numa ingerência do Estado na atividade imobiliária, que se revelou infrutífera para a finalidade a que se propôs.

Em SIMONSEN (1941: 14) pode-se colher importante depoimento sobre os obstáculos estruturais na formulação de uma política habitacional para a baixa renda:

"Esse culto e saudoso médico - referindo-se ao Dr. Guilherme Álvaro -, há mais de trinta anos, denodadamente combatia os cortiços e as habitações insalubres de Santos, e com muita simpatia acompanhou a tentativa que fiz, em 1912, ao fundar a Companhia Santista de Habitações econômicas, de edificar naquele importante porto do estado um bairro operário modelo.

Dados o alto preço da construção ali vigorante e as condições favoráveis de nossas taxas cambiais, abri então concorrência nos Estados Unidos, entre construtores e fabricantes de materiais especializados, visando obter habitações econômicas que seriam edificadas em série, por processos maquinizados.

Recebi várias propostas para a execução do cometimento. Construí, com materiais e projetos norte-americanos, uma primeira habitação coletiva, de oito células, parte integrante que seria um sistema. Verifiquei, porém, com pesar, que a construcão de vivendas populares esbarrava aí, como em toda a parte, com a impossibilidade de remuneração dos capitais nelas invertidos, pela angustiante precariedade dos recursos da massa trabalhadora" (grifo do autor).

Em seguida o empresário arremata com uma constatação, que para os efeitos deste trabalho é crucial: "a existência da 
insuficiência de ganho da maior parte de nossa população, é - grande óbice também para um mais rápido progresso do país". Ora, esta afirmação que revelava a concepção liberal avançada do empresário, toca na questão que sempre esteve na base da segregação social nas metrópoles brasileiras, ou seja, a reprodução da força de trabalho. Revela, ainda, que a questão não era restrita a Santos, mas de caráter e conseqüências gerais.

Assim, pode-se afirmar que a questão da falta de condições dignas de habitação para as classes populares, sempre passou pela agenda governamental de forma superficial, pois esta dela ocupou-se apenas no discurso e fez valer seu poder de polícia para demarcar territórios livres dos "miasmas" e "humores" que tanto atormentavam os sanitaristas do século XIX, induzindo à ocupação desordenada da periferia do núcleo urbano. 


\subsubsection{Período Desenvolvimentista}

"E não se confundam os operários, os trabalhadores, com esses indivíduos que habitam as 'favelas' dos nossos morros. $E$ sobre esse ponto quero chamar a atenção da Câmara porque é urna necessidade ser $o$ assunto cuidadosamente estudado, de vez que vi, no parecer da Comissão de Justiça, referencias àqueles habitantes das 'favelas' do Distrito Federal e verifico o pronunciamento daquele órgão técnico da Casa no sentido da concessão de terrenos para atender a essa população pobre. Mas será obra social atender-se a esses habitantes das 'favelas' do Distrito Federal, que não são, a rigor, operários? Talvez nelas habitam, excepcionalmente, operários da nossa capital. Todos os indivíduos que ocupam essas 'favelas', essas casas, já denominadas casas de cachorro, não são trabalhadores que vivem de um salário honesto. [...] Pergunto à Câmara: será obra social fazer-se uma edificação para esses vadios?"

BONDUKI (1998: 110) ${ }^{40}$

A etapa da expansão da urbanização em Santos, denominada desenvolvimentista, é marcada por uma sucessão de investimentos que consolidaram o papel da Baixada Santista como vínculo entre o mercado internacional e grande parte do sudeste brasileiro. Mais

\footnotetext{
${ }^{40}$ Citando o Boletim do Ministério do Trabalho, Indústria e Comércio, (1937: 229-30).
}

ainda, esses investimentos inseriram a região na era industrial, como parte da base petroquímica e siderúrgica que faria impulsionar a indústria paulista, sobretudo após o segundo pós-guerra.

No fim do período anterior, em termos de infra-estrutura básica foram notáveis as obras das usinas hidrelétricas de Itatinga, em 1906, e Henry Borden, em 1926. Esta última foi a maior obra brasileira do setor energético da primeira metade do século (REIS FILHO, 1989). Houve ainda, além das melhorias na malha rodoviária, a construção da estrada ligando São Paulo até a serra, explorada por particulares e depois desapropriada em 1923, quando foi feita a pavimentação em concreto da estrada da Serra do Mar e a pavimentação em asfalto no trecho do litoral.

Em Santos os serviços públicos de bondes, luz, energia, gás, água e esgoto eram explorados pela The City of Santos Improvements Company Ltd. Os primeiros bondes elétricos circularam em 24 de abril de 1909 e foram decisivos para o desenvolvimento e ocupação das zonas Leste e Noroeste da cidade, possibilitando também sua ligação com São Vicente pela orla da praia e pela Zona Noroeste.

Como resultado da primeira fase de expansão, a cidade já havia experimentado um grande salto demográfico, passando de 9.871 habitantes em 1872, a 88.967 em $1913^{41}$. Na segunda fase, após a $2^{\text {a }}$ Guerra Mundial, o salto seria igualmente significativo, não só para Santos mas para os demais municípios da Baixada Santista, tornando-a uma das regiões mais densamente habitadas do Brasil, com uma população quase totalmente urbana (ver Tabela 6), uma vez

\footnotetext{
${ }^{41}$ Fonte: CARDOSO e SACS (1985), apud LANNA (1996: 51).
} 
que a atividade agrícola declinou na mesma proporção em que cresceram os setores terciário e secundário.

\section{Tabela 10}

\section{População da Baixada Santista - Evolução Histórica}

\begin{tabular}{|c|c|c|}
\hline Ano & População & Taxa Anual de Crescimento \\
\hline 1830 & 6.608 & - \\
\hline 1854 & 7.732 & 0,9 \\
\hline 1874 & 10.784 & 1,7 \\
\hline 1886 & 16.696 & 3,7 \\
\hline 1900 & 54.393 & 8,8 \\
\hline 1920 & 110.245 & 3,6 \\
\hline 1934 & 163.107 & 2,8 \\
\hline 1940 & 190.401 & 2,6 \\
\hline 1950 & 260.252 & 3,1 \\
\hline 1960 & 408.917 & 4,6 \\
\hline 1970 & 626.746 & 4,4 \\
\hline 1980 & 905.743 & 3,7 \\
\hline
\end{tabular}

Fonte: ASSECOB (1984: 100).

No final da Primeira Guerra Mundial tivemos o primeiro salto da indústria paulista, que já detinha $31 \%$ da produção nacional (LEME, 1982). A década de 1916/1925 foi caracterizada por grandes obras no porto. Em 1926 foi elaborado $01^{\circ}$ Plano de Desenvolvimento do Porto de Santos. Esse plano previa a expansão das obras, aumentando o cais de $5 \mathrm{Km}$ para $33 \mathrm{Km}^{42}$. Em 1929, com a quebra da bolsa de Nova York, teve início a recessão norteamericana e a política protecionista do setor cafeeiro, já estando Getúlio Vargas no poder, com a queima de estoques de 1931 a 1933. Foi, para o Estado de São Paulo,

\footnotetext{
$42 \mathrm{Na}$ verdade, o cais da margem direita, do lado de Santos, nunca passou de $11 \mathrm{Km}$ de extensão.
}

a superação do ciclo cafeeiro pelo industrial, em termos de importância econômica ${ }^{43}$. Foi para a Baixada Santista o marco do fim da sua primeira fase de desenvolvimento, na qual o financiamento das obras de infra-estrutura foi mais dependente do setor privado.

A fase desenvolvimentista foi a fase da industrialização e da democratização $^{44}$ do turismo balneário, como fonte de renda para grande parte da população. Em 1947, no governo estadual de Adhemar de Barros, era inaugurada a primeira pista da primeira "auto-estrada" nacional, a Via Anchieta, que ligava o planalto à Baixada. Em 1953 era inaugurada sua segunda pista. Desde então a geografia da região modificou-se, com a emancipação dos municípios de Guarujá e Cubatão, desmembrados de Santos, em 1934 e 1948, respectivamente. Em 1945 foi concluída a montagem do primeiro trecho de um oleoduto, visando sua interligação com o Terminal da llha Barnabé, alavancando uma das mais importantes fases do porto, a do petróleo.

Contudo, uma das conseqüências da construção da Via Anchieta foi a ocupação de trechos da vertente atlântica da Serra do Mar, em Cubatão. Esses núcleos habitacionais trouxeram conseqüências extremamente danosas do ponto

\footnotetext{
43 Para melhor compreender a questão, é fundamental a leitura de FURTADO (2000).

${ }^{44}$ Como apontou SERRANO (1991: 50), "já em 1893, na Praia das Pitangueiras, Guarujá, foi fundada a 'Vila Balneária' (... com) 46 chalés, uma igreja e um hotel de 50 quartos (...) A iniciativa incluía uma estrada de ferro que ligava o núcleo turístico até uma estação de barcas junto ao Rio do Meio, no Estuário, (...), onde famílias da elite paulista chegavam em barcas que as traziam da estação do Valongo (Santos)". Da mesma forma, a orla de Santos foi paulatinamente sendo ocupada por palacetes da elite paulista. Apenas com a abertura da Via Anchieta o turismo balneário popularizou-se, na Baixada Santista.
} 
de vista ambiental e da segurança e condições gerais de moradia de seus moradores. Hoje eles são conhecidos como "Bairros Cota" e são assentamentos subnormais dos mais antigos da Baixada Santista (ver Tabela 13). Os Bairros Cota são, atualmente, um conjunto de cinco assentamentos surgidos junto ao traçado da Via Anchieta e, posteriormente, junto à Rodovia dos Imigrantes ${ }^{45}$. Estes assentamentos foram resultado do grande contingente de trabalhadores com baixa qualificação atraídos pela construção destas rodovias e que não obtiveram outra alternativa habitacional.

A opção pela industrialização, iniciada antes da segunda guerra, e o ideário desenvolvimentista implementado pelo presidente Juscelino Kubitschek, que assume a presidência em 1956, deu início à indústria automobilística da região do $\mathrm{ABC}$, à implantação do Pólo Petroquímico e do Parque Siderúrgico, em Cubatão. Foram obras de grande porte e valor estratégico nacional, que atraíram grandes contingentes de mão de obra para a construção civil nas décadas de 50 e 60. Estas décadas foram caracterizadas também pela estatização dos serviços públicos, como as ferrovias, o saneamento, o gás e o transporte urbano.

Esse foi o início de uma fase na qual foi predominante o papel do setor público. É precisamente nesse momento que começou a modificar-se a importância da região no contexto estadual e nacional. Como aponta VILLAÇA (1998: 136):

"Até a década de 1950, o porto de Santos desempenhava um papel de excepcional importância no intercâmbio entre a indústria paulistana e 0 restante do país e mesmo do mundo. Até essa

\footnotetext{
45 Rodovia de interligação entre a Baixada Santista e a RMSP,
} construída na década de 70 do século $X X$. época, assemelhava-se o Brasil a um arquipélago, tamanha a autonomia que tinham suas diferentes regiões, que, na verdade, eram 'cercadas de água por todos os lados', pois quase todo o transporte que se fazia entre elas se dava era pelo mar. A Área Metropolitana de São Paulo comerciava com o Brasil através de Santos, tanto na importação de matériasprimas como na exportação de produtos industrializados. Os fluxos de transporte entre Santos e a metrópole eram excepcionalmente intensos. Junto às vias que atendiam a estes fluxos, as indústrias procuravam acesso ao país todo. Entretanto, a partir de 1950, uma rede de rodovias pavimentadas passou a integrar o território nacional, e a via Dutra passou a ligar mais do que São Paulo ao Rio, o que já era suficientemente importante, mas também São Paulo ao Nordeste e a uma parte de Minas. A indústria, que antes privilegiava a direção de Santos, começou então a localizar-se também ao longo da via Dutra, a nova localização 'próxima ao Brasil'. Ao longo dessa rodovia e já agora extrapolando a área metropolitana oficial, instalou-se não só a indústria automobilística - a General Motors e a Volkswagen -, mas a nova indústria de ponta - a de guerra, a espacial, a eletrônica e a aeronáutica".

Se por um lado a nova estruturação do espaço nacional e da região sudeste provocou a redução da importância relativa da RMBS, a indústria automobilística, a facilidade de acessos, o desenvolvimento econômico do estado e a idéia de que os banhos de mar eram saudáveis desenvolveu outra face da região ${ }^{46}$, o turismo, que se

\footnotetext{
46 Segundo ARAÚJO FILHO (1965), "É por volta de 1947, com a inauguração de uma nova e moderna ligação com o planalto, a Via
} 
transformou na década de 60 , com o porto e as indústrias de Cubatão, no tripé econômico da Baixada Santista.

A partir das décadas de 1940 e 1950, o centro da cidade modificou-se, com a evasão definitiva das famílias mais abastadas para a região da orla e a construção, à beira mar, de muitos edifícios para o turismo. Neste período a construção civil foi a grande empregadora. A avenida da orla e a reforma dos jardins da praia, o túnel ligando a Zona Leste ao Centro (ver Figura 13) e a complementação do sistema de canais até o bairro da Ponta da Praia foram obras executadas nessas décadas e fundamentais para a estruturação de Santos.

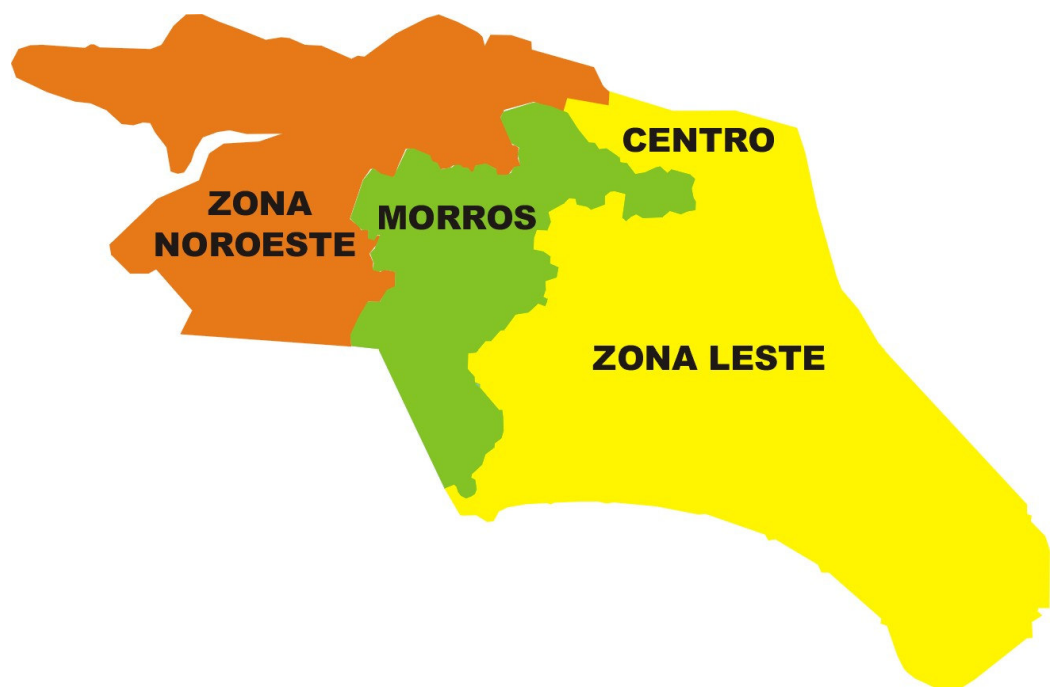

Figura 13 - Divisão da área insular do Município de Santos, segundo suas principais regiões.

Anchieta, que o impacto da função balneária, por ele denominada de veraneio, foi sentido no progresso da cidade (Santos)" apud SEABRA (1979: 18).
Os edifícios construídos ao longo da avenida da praia criaram a possibilidade de absorção da mão de obra oriunda do pólo industrial e que não foi por ele aproveitada (ver Figura 15). Criaram, também, uma peculiar paisagem, a "muralha" que hoje se estende do Guarujá à Mongaguá, e configura-se num dos maiores problemas da Região, o turismo de segunda residência ${ }^{47}$. Esse modelo de turismo demanda o máximo da infra-estrutura urbana durante os picos das temporadas, deixando-a parcialmente ociosa durante a maioria dos meses. Esse desequilíbrio perdura até hoje ${ }^{48}$.

\footnotetext{
${ }^{47}$ Segundo SEABRA (1979: 19), "O apartamento emerge então como modalidade de alojamento para uma população diferenciada em termos de poder de compra. Diferenciada em princípio, pelo fato de poder ter uma segunda residência", referindo-se à classe média paulista que fez de Santos e região seu destino preferencial, neste período. A autora revelou, também, dados de sua pesquisa sobre Santos (1979: 104), segundo os quais, a primeira fileira de edifícios abrigava, em 1976, 70\% de unidades de segunda residência, e no total de edifícios da primeira fileira de quadras a média era de $40 \%$, na mesma data.

${ }_{48}$ Ainda, segundo SEABRA (1979: 111), "inquilinos e proprietários vindos de fora que, ao usarem em caráter permanente essas habitações, estão criando o 'novo'. O novo porque através da penetração do uso permanente das habitações do tipo menores e piores que se está redefinindo o uso da segunda residência, as quais estariam perdendo esta característica". De fato, os apartamentos tipo quarto-e-sala conjugados, bem como os de um ou dois quartos, utilizados pelo turismo de segunda residência, vêm sendo ocupados, mais e mais, desde a década de 1970, por população de média e alta renda, ao longo da orla marítima de Santos e São Vicente.
} 


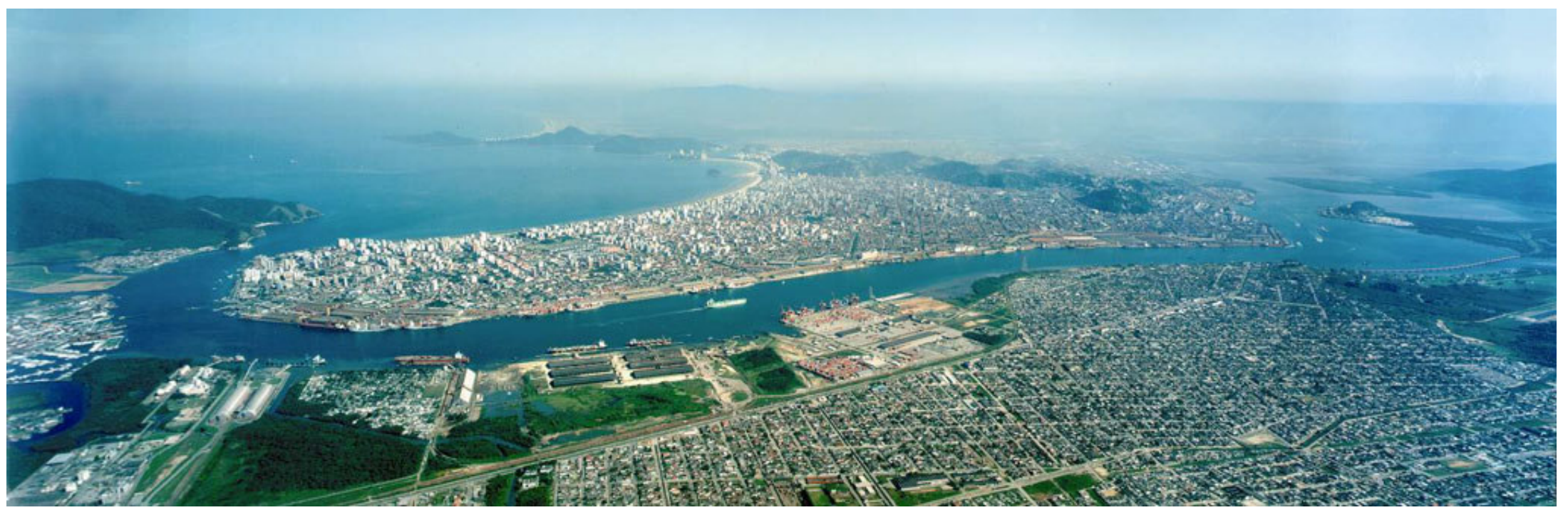

Figura 14 - Vista panorâmica da área insular de Santos, a partir do distrito de Vicente de Carvalho, em Guarujá - em primeiro plano com a orla da praia e sua "muralha" de edifícios ao fundo. Fonte: sítio da CODESP na rede mundial de computadores www.portodesantos.com, 2001.

Outra decorrência negativa da construção da "muralha" de edifícios foi a queda da qualidade ambiental, pois como verificou SEABRA (1979: 27), "À frente dos quarteirões litorâneos dominam as construções com mais de 10 pavimentos, formando uma muralha de arranha céus a qual já se referira ARAÚJO FILHO (1965)". Este fenômeno é responsável pelo bloqueio dos ventos que vêm do oceano, contribuindo para o aquecimento das cidades litorâneas.
Nas décadas seguintes, pela alteração da importância, como destino turístico, das cidades da periferia da RMBS, municípios como Praia Grande, Mongaguá, Itanhaém, Peruíbe e Bertioga passaram a enfrentar mais problemas, durante a temporada de veraneio e feriados prolongados, no que concerne à saturação da infra-estrutura. Segundo dados recentes, em Bertioga a população chega a triplicar no verão, em Mongaguá ela duplica e em Santos o crescimento relativo da população flutuante chega a $1 / 3$ da população fixa ${ }^{49}$.

A partir da década de 1950, os conjuntos habitacionais, fossem os de unidades uni-familiares, fossem os de edifícios de apartamentos, passaram a ser a alternativa

\footnotetext{
${ }^{49}$ Fonte: SABESP, 1998.
} 
oficial de enfrentamento do crescente déficit habitacional. Foram vários os empreendimentos do gênero na região, como os conjuntos da Companhia Santista de Habitações Econômicas, Fundação da Casa Popular, dos IAP e, posteriormente do $\mathrm{BNH}, \mathrm{COHAB}$ Santista e prefeituras locais. Nos municípios da RMBS foram erguidos conjuntos como: Tancredo Neves, em São Vicente; Costa e Silva, Estivadores, Dale Coutinho e Athiê Jorge Coury, na Zona Noroeste de Santos.

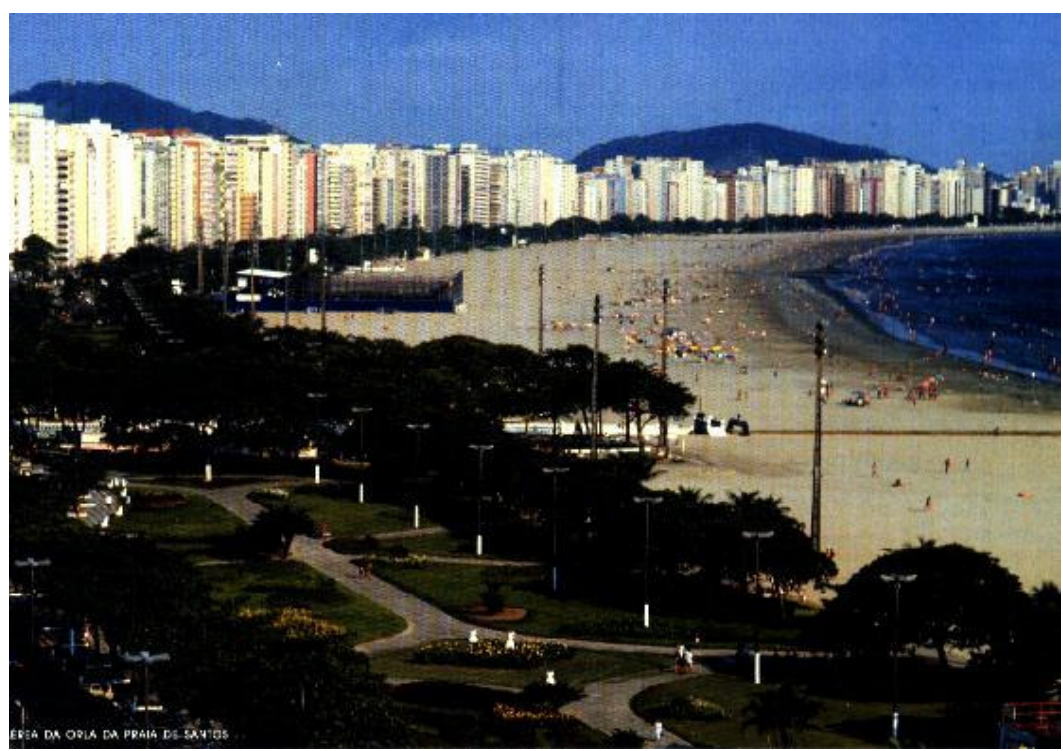

Figura 15 - "Muralha" de edifícios, muitos dos quais de segunda residência, na orla de Santos. Foto do autor, 1999.

Em Santos, o empreendimento mais importante surgiu a partir de 1967, ano em que uma concorrência pública para desenvolver 0 projeto habitacional em área hoje pertencente ao bairro da Aparecida permitiu a construção do "Conjunto do BNH", como é hoje conhecido. O conjunto conta com 2.800 unidades, além de estarem previstos "jardins e parques para os filhos dos trabalhadores", nas palavras do arquiteto Oswaldo Corrêa Gonçalves, autor de seu projeto.

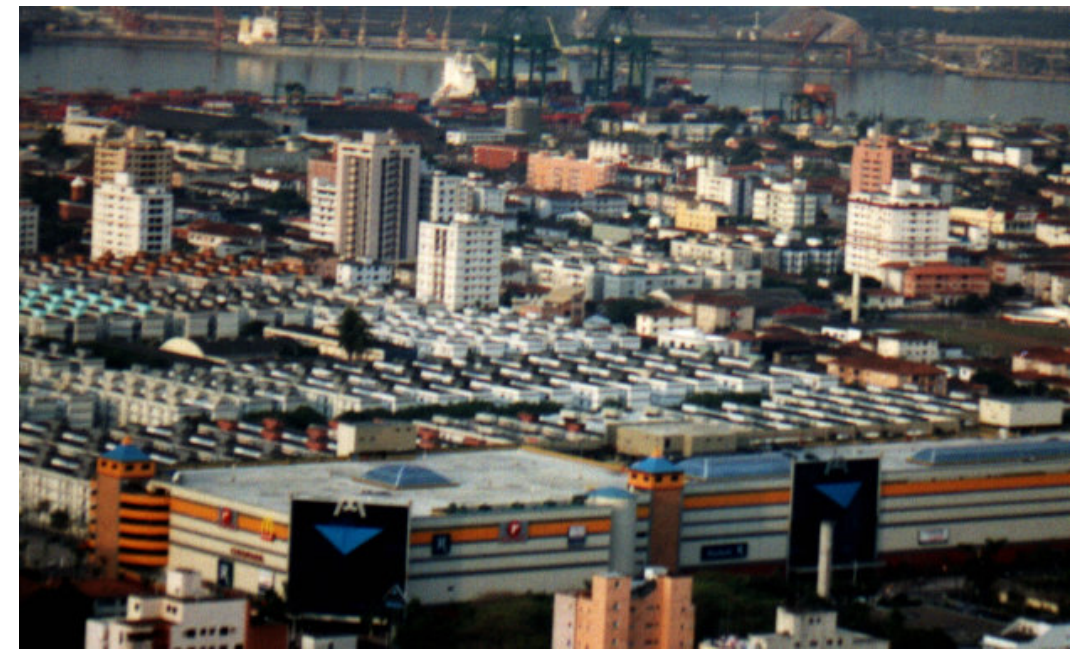

Figura 16 - Vista aérea, em segundo plano, do conjunto habitacional BNH da Aparecida, Santos. Foto do autor, 2000.

Entretanto, esse e outros conjuntos não foram suficientes para absorver o grande número de migrantes que continuavam a chegar à região, atraídos pelas oportunidades de trabalho em várias frentes. Em grande parte, suas unidades acabaram servindo como alternativa habitacional à classe de média renda. Isso ocorreu, ao que parece, porque as classes mais pobres não tinham como se habilitar ao financiamento para estas unidades. 
Outras obras também foram importantes para a região, como as rodovias Cubatão-Pedro Taques e Manoel da Nóbrega - que ligam a Baixada ao litoral sul e Vale do Ribeira - esta última inaugurada em 1976; bem como Piaçaguera-Guarujá e D. Domenico Ranghoni - a segunda mais conhecida como Rio-Santos, inaugurada em 1984 (ver Figura 5).

A implantação do ramal da Rede Ferroviária Federal RFFSA, conhecido como Conceiçãozinha, na margem esquerda do porto, em Guarujá; bem como o prolongamento do cais, na margem direita, com a criação do Corredor de Exportação, em Santos, também são obras de infra-estrutura desse período que merecem destaque (ver Figura 5).

Alguns empreendimentos em Santos, como o Aquário e o Orquidário municipais, tornaram-se os mais importantes equipamentos turísticos da cidade nas décadas de 40 e 50 . Posteriormente, nos anos 50 e 60 o sistema viário da cidade passou por uma significativa remodelação e diversos outros equipamentos públicos foram implantados.

Em 1964, com a ruptura institucional efetivada pelo golpe militar, a centralização do poder levou as decisões para uma esfera ainda mais distante. Santos perdeu sua autonomia política em 1969 - só retomada em 1984 - e foi declarada "Área de Segurança Nacional". Esse período da história da região foi especialmente crítico, marcando o seu declínio em importância com relação a outras regiões do Estado. Isto ocorreu, sobretudo, pela queda da qualidade ambiental, devida à poluição industrial, portuária e doméstica, em função do grande adensamento junto à orla e o surgimento de numerosos novos assentamentos subnormais. Este fenômeno fez com que parte dos veranistas substituísse a cidade e região como principal destino turístico no estado ${ }^{50}$

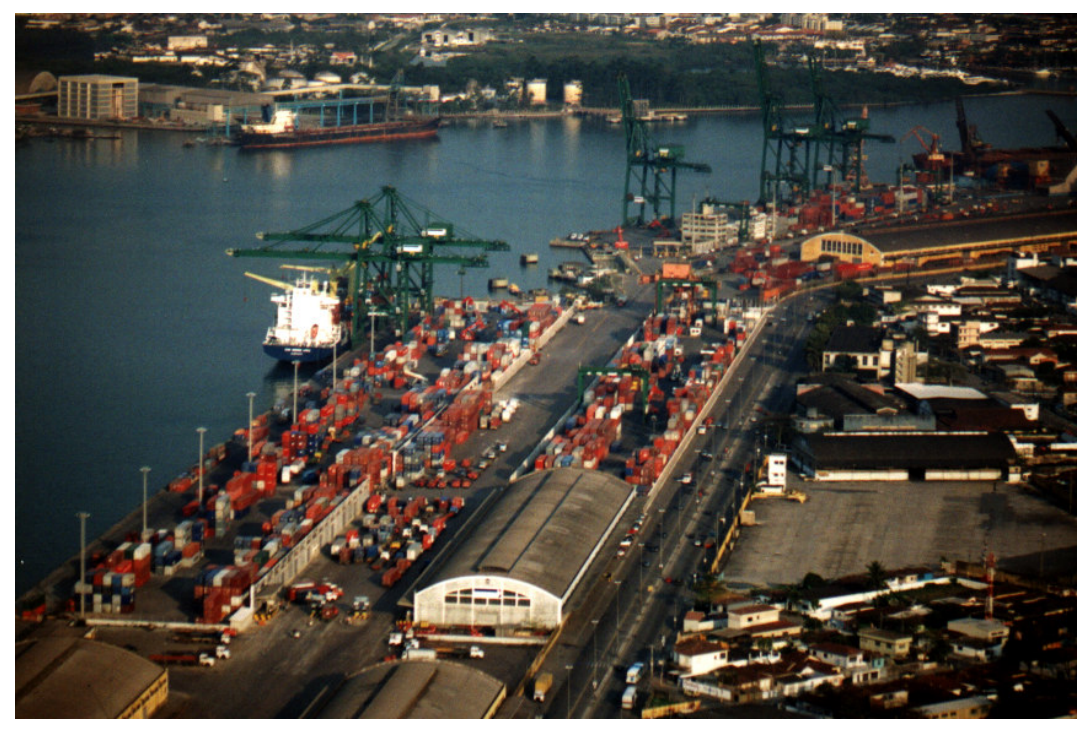

Figura 17 - Vista aérea do Corredor de Exportação, na margem direita do Porto de Santos, 2000.

Com grande contingente de população fixa e flutuante, além do desenvolvimento econômico e seus impactos sócioambientais, o saneamento e o acesso à região voltaram a

\footnotetext{
${ }^{50}$ Foi somente no início da década de 1990 que o Governo de Estado e a Prefeitura de Santos iniciaram um programa de melhoria da balneabilidade, visando recuperar o potencial turístico da cidade. Ao longo desta década, atendendo a pressões das prefeituras locais, o governo estadual iniciou um programa de saneamento em assentamentos subnormais, de amplitude ainda insuficiente para atender o conjunto dos núcleos de baixa renda da RMBS.
} 
demandar novas grandes obras. Em 1967 teve início a construção de uma das mais modernas rodovias brasileiras, a Rodovia dos Imigrantes (ver Figura 5), e na década de 1970 a construção do interceptor oceânico e do emissário submarino, em Santos, ambas a cargo do governo do Estado.

Revendo os conceitos de esgotamento sanitário, devido às mudanças da forma de ocupação do solo e de implantação de estradas, essas obras acabaram, juntamente com a construção civil de segunda residência, ocupando a mão de obra existente e atraindo maior contingente de trabalhadores com baixa qualificação profissional.

Mas com a estagnação econômica após a crise do petróleo, sobretudo nos anos 80, esta mão de obra tornou-se ociosa, em grande parte, gerando um grave problema de desemprego e subemprego. Esse fato, aliado à valorização imobiliária nas áreas próximas à orla marítima das ilhas de São Vicente e Santo Amaro, agravou o aumento da ocupação desordenada da Serra do Mar, em Cubatão; dos morros de Santos, antes ocupados apenas por famílias de imigrantes portugueses, e do Guarujá ${ }^{51}$. Também as várzeas da planície costeira e os manguezais - como nas áreas dos diques de Santos e São Vicente - e de Guarujá e Cubatão foram objeto do estabelecimento de dezenas de assentamentos subnormais.

\footnotetext{
51 Segundo SERRANO (1991: 34-35), as habitações subnormais nos municípios centrais da Baixada Santista - incluindo Praia Grande, que em 1980 quase não possuía este tipo de habitação - passaram de 95.612, em 1980 e para 392.408, em 1988. Fontes: FIBGE e Comissão Interministerial; Grupo Técnico de Planejamento da Baixada Santista GPLAN, respectivamente.
}

Segundo SERRANO (1991: 34), as submoradias constituíam 10,6\% das moradias em Santos, São Vicente, Guarujá, Cubatão, em 1980. A população em assentamentos subnormais era de, 36.748 habitantes em Santos, 17.889 em São Vicente, 25.937 em Guarujá e 15.038 em Cubatão ${ }^{52}$, respectivamente,

Também, em função do reduzido território insular de Santos e da impossibilidade de fixação da população de baixa renda na Zona Leste, grande concentração de assentamentos subnormais surgiu nas áreas ambientalmente mais frágeis, sobretudo nos municípios vizinhos a esta cidade. Estes municípios, como será visto no Capítulo 4, exerciam menor controle da ocupação do território e nestes proliferou a indústria dos loteamentos clandestinos e irregulares, a exemplo do processo ocorrido na Região Metropolitana de São Paulo, sobretudo nas áreas de proteção aos mananciais.

Pode-se afirmar que o processo de ocupação desordenada em grande parte dos territórios de São Vicente, Vicente de Carvalho - distrito de Guarujá - e Cubatão está ligado à grande valorização dos imóveis em Santos.

Há, porém, um grande número de assentamentos que surgiram devido a fenômenos endógenos destes municípios, sempre vinculados á demanda de mão de obra para a produção de edifícios de segunda residência, como são os casos dos Bairros Cota, em Cubatão e das favelas nas vertentes da Serra de Santo Amaro, em Guarujá, por exemplo.

\footnotetext{
${ }^{52}$ Fontes: FIBGE, 1982 e Comissão Interministerial, 1982.
} 


\subsection{As formas de acesso e tipologias habitacionais das classes de baixa renda da RMBS}

É a partir do Período Desenvolvimentista que as áreas inundáveis e a maior parcela dos morros de Santos, São Vicente, Guarujá e Cubatão e, posteriormente, a área continental de São Vicente ${ }^{53}$, surgiram como alternativa de localização para as classes de baixa renda ${ }^{54}$. Em geral são áreas sujeitas à ação da maré, ou mesmo sobre os canais do estuário, em que a população mais pobre ergueu suas palafitas. São também as encostas dos morros, desta vez mais distantes do centro de Santos, a serem ocupadas por populações que não detinham a técnica para construção nesses sítios. Também nesse período o cortiço subsistiu como tradicional forma de moradia para estas classes.

Nas décadas de 50 e 60 do século $X X$, a questão da falta de habitação para a classe trabalhadora era um problema de difícil solução. A alternativa oficial para enfrentamento desta questão foi a construção de conjuntos habitacionais, sempre em número insuficiente e com formas de financiamento inadequadas ${ }^{55}$, e a extra-oficial foi 0

\footnotetext{
${ }^{53}$ Para referência, consultar cartografia do Município de São Vicente, no item 4.2.1.

54 No Período Desenvolvimentista, segundo os censos da FIBGE, a população de baixa renda que habitava os assentamentos subnormais na Baixada Santista era formada por operários do Porto, do Parque Industrial de Cubatão, da construção civil e de empregados no setor terciário, em sua maioria migrantes nordestinos, regiões mais pobres dos estados de São Paulo e de Minas Gerais. A imigração européia que havia diminuído consideravelmente entre as duas grandes guerras, tomou novo impulso, ainda que em menor intensidade, após a Segunda Guerra Mundial, vindo a cessar na década de 1960.

55 Em BONDUKI (1998) essa questão foi aprofundada e vários exemplos desse tipo de intervenção estatal e privada são citados. No caso específico da Baixada Santista, foram citados o núcleo de casas
}

proposital consentimento à ocupação indiscriminada do território da Baixada, das formas mais predatórias possíveis. Assim, a alternativa real, preponderante foi a nova proliferação de cortiços, em Santos, a ocupação de encostas, várzeas e mangues, com o surgimento do loteamento "clandestino" de periferia ou das favelas, tão difundidos neste município e em Cubatão, São Vicente e Guarujá.

Sobre o loteamento irregular de periferia, pode-se ler em BONDUKI (1998: 94) uma excelente análise:

"O modelo de expansão periférica, ainda que equacionando o acesso a casa própria, também iria sofrer criticas dos que percebiam seu significado em termos de deseconomia urbana: 'A cidade de crescimento ilimitado é um mal. Quanto maior, mais cara a sua administração per capita' (MORAES, 1942:113). Esses analistas preocupavam-se com o custo de urbanização, transportes e infra-estrutura que a ocupação acelerada da periferia acabaria gerando para a cidade, alertando que esse tipo de barateamento da moradia poderia custar caro no futuro:

'E desse retalhamento resultou ser a cidade de São Paulo, hoje, uma das maiores do mundo em extensão, o que não a recomenda ate o presente por não ter sido possível a Prefeitura provê-la dos

construído pela Fundação da Casa Popular (1998: 124) e o conjunto de edifícios do IAPI (1998: 151), no Bairro da Aparecida, ambos em Santos. Na verdade, o autor afirmou que grande parte desses empreendimentos foi utilizada politicamente, com regras de acesso pouco democráticas. Além disso, mesmo os conjuntos de elevado valor arquitetônico, que privilegiavam o uso de grandes áreas comunitárias, foram pouco a pouco sendo desvirtuados, tendo seus espaços comuns privatizados e perdendo muito em qualidade. 
serviços de águas, de esgotos, de transportes e de tantos outros melhoramentos urbanos' (BARBOSA 1942:148)".

Mais adiante BONDUKI (1998: 286) completou,

"A despeito dos evidentes e conhecidos problemas que esse modelo de ocupação (ilegal clandestina, antiurbana, insalubre, precária e contrária aos princípios da técnica urbanística) trariam para a cidade no futuro, formou-se uma espécie de conluio branco entre loteadores, compradores, Executivo, Legislativo e Judiciário para não se criar empecilhos ao livre desenvolvimento desse tipo de empreendimento. A liberdade corn que se processou, durante décadas, a transformação, sem projeto nem obras, de glebas rurais em lotes teoricamente urbanos, foi decisiva para a difusão do sistema de auto-empreendimento".

E também, em BONDUKI (1998: 288), pode-se encontrar as razões do fenômeno da ocupação extensiva do território das metrópoles brasileiras: "A omissão do poder público na expansão dos loteamentos clandestinos fazia parte de urna estratégia para facilitar a construção da casa pelo próprio morador que embora não tivesse sido planejada, foi se definindo na pratica, corno um modo de viabilizar uma solução habitacional 'popular', barata, segregada, compatível com a baixa remuneração dos trabalhadores e que, ainda, Ihes desse a sensação, falsa ou verdadeira, de realizar o sonho de se tornarem proprietários".

Na Baixada Santista, os exemplos mais típicos deste tipo de ocupação surgiram na Zona Noroeste de Santos (ver Figura
13), no setor oeste da Ilha de Santo Amaro ${ }^{56}$, em Guarujá e em São Vicente, junto aos diques e em sua área continental $^{57}$. No caso de Santos, esses loteamentos irregulares estão em sua maioria integrados à malha urbana e dotados de infra-estrutura em níveis bastante aceitáveis. No Guarujá, várias ações dos governos federal e municipal, durante a década de 1970, permitiram mitigar a falta de infra-estrutura em parte destes núcleos. No entanto, em São Vicente a situação ainda é grave, sobretudo na área continental, distante do centro da cidade.

Por outro lado, o problema das ocupações em encostas veio a agravar-se em Santos e São Vicente, sobretudo. Segundo SERRANO (1991: 31), em 1950, "escorregamentos na encosta do Monte Serrat mataram 3 pessoas e feriram diversas". Mais adiante, o autor acrescentou: "Em 2 de março de 1956, 22 pessoas morreram, dezenas ficaram feridas e 50 casas foram destruídas em conseqüência de vários escorregamentos no Morro de Santa Terezinha". Ainda, em 26 de março de 1956, "Quarenta pessoas morreram por escorregamentos em Santos e São Vicente... Foram feridas 102 pessoas e quatro mil ficaram desabrigadas". Mais tarde, em 1978, conforme SERRANO (1991: 32), "Em 15 de janeiro de 1978 (um domingo), quatro pessoas de uma mesma família morreram... Mais de 100 pessoas foram atingidas em razão de escorregamentos no Monte Serrat e Morro da Nova Cintra. No ano seguinte, em 16 de dezembro de novo nos

\footnotetext{
56 Para referência, consultar cartografia do município de Guarujá, no item 4.2.2.

${ }^{57}$ Para referência, consultar cartografia do município de São Vicente, no item 4.2.3.
} 
Morros da Nova Cintra e Jabaquara, escorregamentos causaram 11 mortes e deixaram vários feridos".

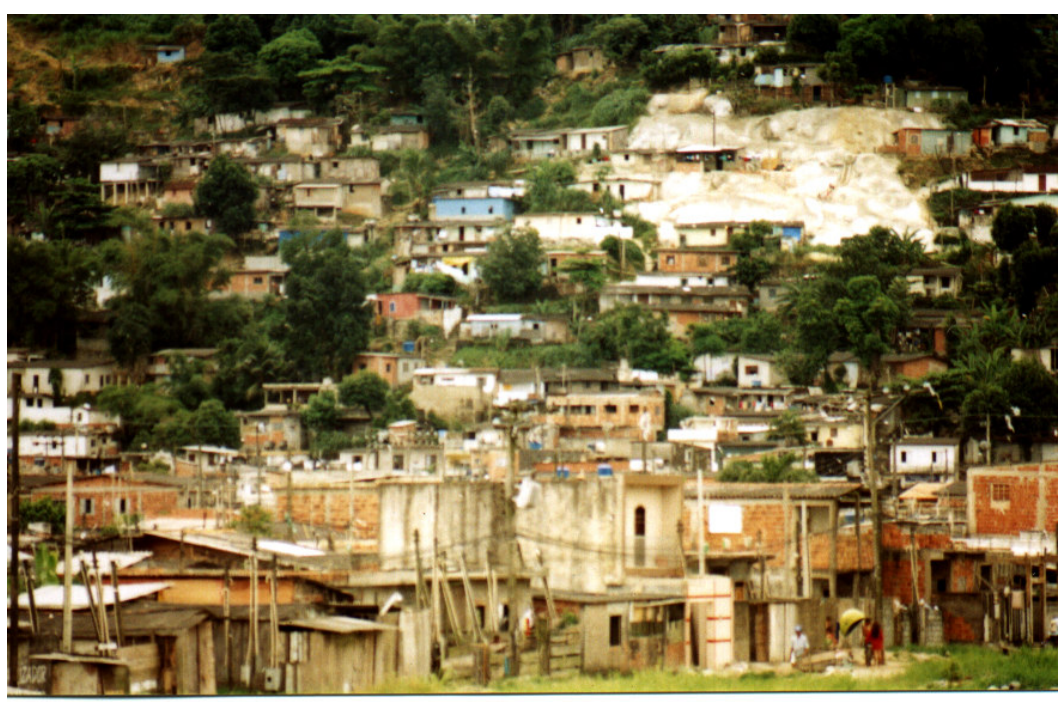

Figura 18 - Ocupações nas encostas da Serra de Santo Amaro, vertente norte - Morro da Cachoeira. Foto do autor, 2002.

No aspecto fundiário, a fixação da população nas áreas dos morros, especialmente nos morros de Santos, sempre foi mais complicada, em relação ao que ocorreu nas várzeas e manguezais. As glebas dos morros, quase todas elas, eram de antigos proprietários e devido a sua proximidade com o centro possuíam maior valor imobiliário, ainda que quase sem infra-estrutura e difícil acesso. Por isso, o processo de ocupação destas áreas, pela população de baixa renda, tem sido marcado por conflitos.

Esse processo fundiário perverso, até hoje, tem lugar nos morros. As propriedades são geralmente de grandes dimensões. São antigos sítios, anteriormente utilizados para atividades agrícolas ou para a retirada de aterro. Por estarem subutilizadas, em virtude da especulação imobiliária, as populações pobres as foram invadindo paulatinamente.

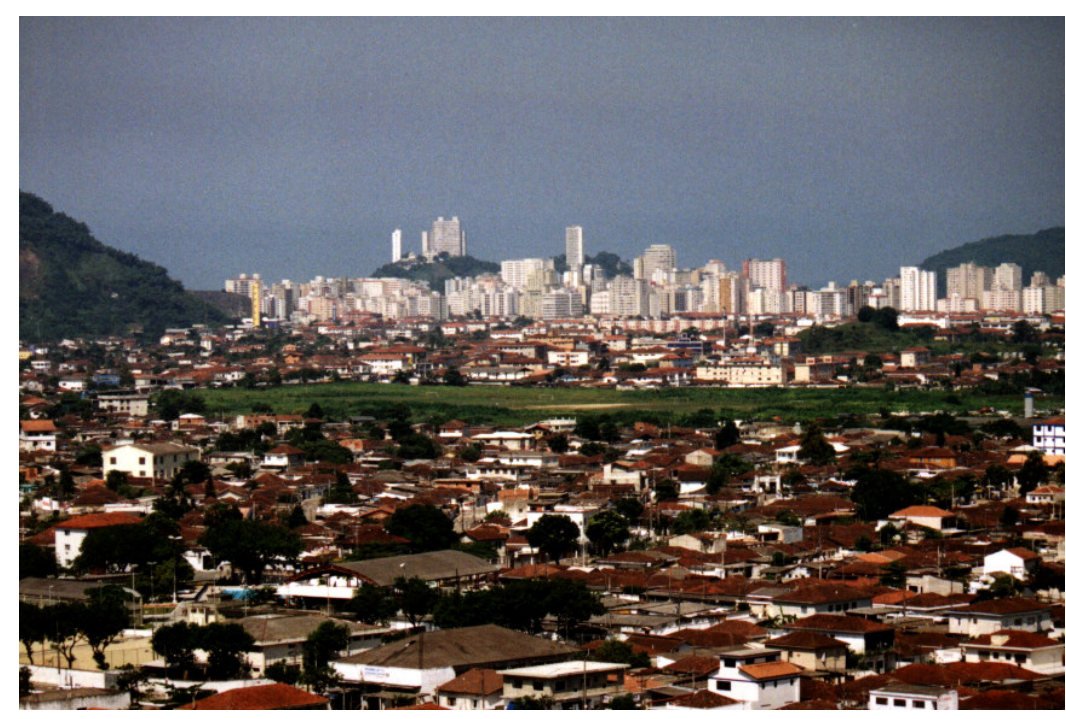

Figura 19 - Vista geral da Zona Noroeste de Santos, com a cidade de São Vicente ao fundo. Foto do autor, 2001.

A perversidade consiste no fato de que os proprietários ameaçam reintegrar a posse, mas acabam fazendo acordos em que o terreno é alugado, sendo a benfeitoria construída pelo invasor. Decorre daí o surgimento do instituto informal do "aluguel de chão", típico dos morros de Santos. Esses acordos são formas de burla à lei de parcelamento do solo, mas foram tolerados por sucessivos governos municipais que fecharam os olhos para o grave problema social. 


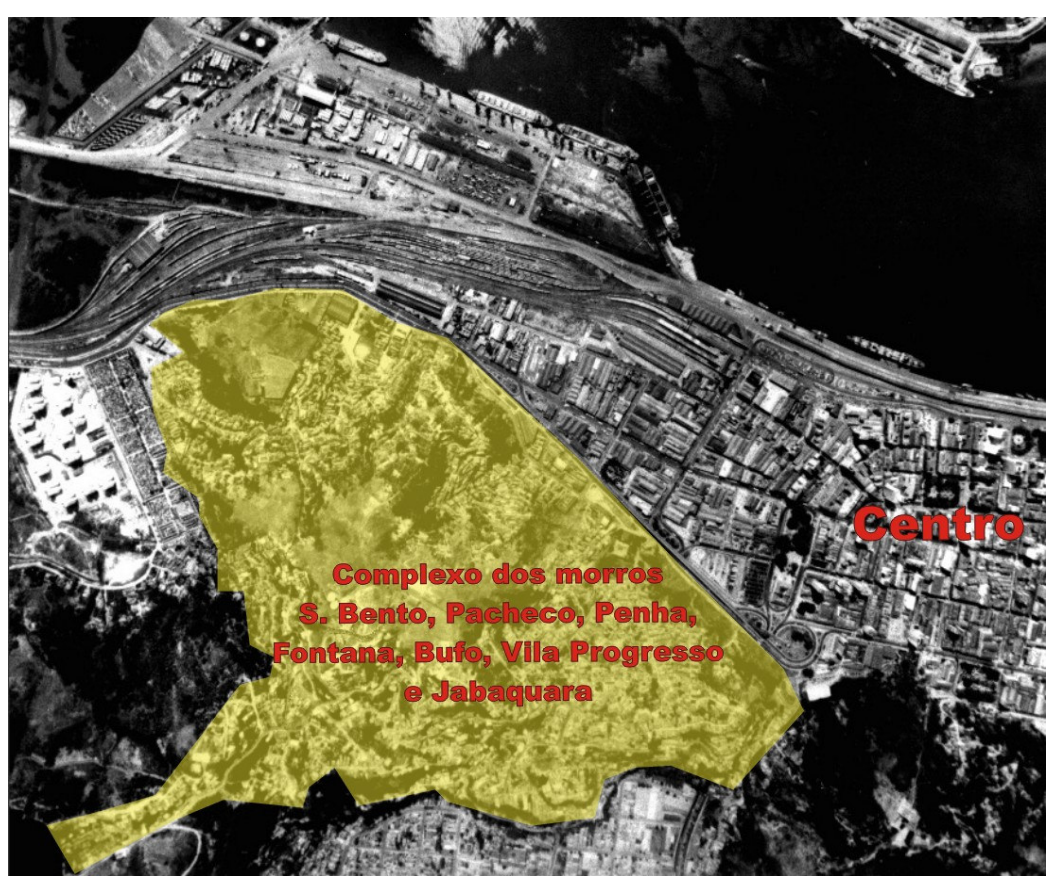

Figura 20 - Foto aérea de área onde predominam assentamentos subnormais nos morros São Bento, Pacheco, Penha, Fontana, Bufo, Vila Progresso e Jabaquara, junto ao centro de Santos. Fonte: Eletropaulo, 1987.

Os proprietários dessas áreas utilizam seus ocupantes para pressionar o poder público a implantar infra-estrutura nos locais. Assim, vários morros vieram a ser urbanizados, muitos deles com infra-estrutura completa, mas com situação fundiária precária. Ironicamente, os investimentos públicos nessas glebas acabam por valorizá-las e provocar a alta dos "aluguéis de chão". Esse processo é terrível, pois essa alta provoca inadimplência e muitas vezes os ocupantes sofrem despejos, perdendo todo investimento realizado em suas benfeitorias, as quais ficam incorporadas ao terreno e são sucessivamente alugadas pelos proprietários das glebas.

Assim, o valor dos investimentos públicos é incorporado ao patrimônio dos proprietários e os investimentos da população de baixa renda também. Esta é a lógica fundiária perversa e tradicional nos morros de Santos.

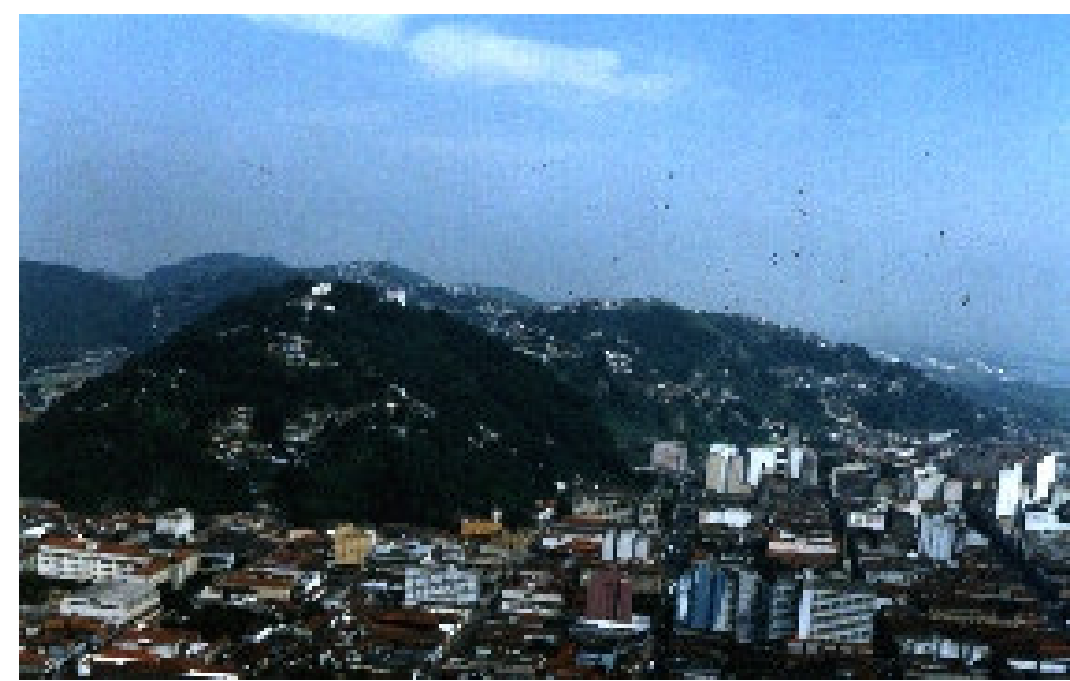

Figura 21 - Vista geral do maciço de morros no centro da llha de São Vicente. Fonte: Arquivo da Administração Regional dos Morros da Prefeitura Municipal de Santos, 1996.

Vale ressaltar também, que essas áreas somente foram objeto de legislação de uso do solo detalhada em 1992, com a criação das Zonas Especiais de Interesse Social ZEIS. Até então, como será visto no Capítulo 4, a legislação aplicável aos morros era muito genérica e a única área 
dessa região a merecer preocupação, no sentido do estabelecimento de regras mais claras e específicas para sua ocupação, foi o Morro da Nova Cintra ${ }^{58}$. Na verdade, este morro é uma planície no alto e no centro do maciço de morros da llha de São Vicente. É a única área deste maciço que guarda semelhança com as áreas de baixada e por isso passou a ter grande valor imobiliário. Isso explica porque essa área foi objeto de um zoneamento mais acurado, em 1968.

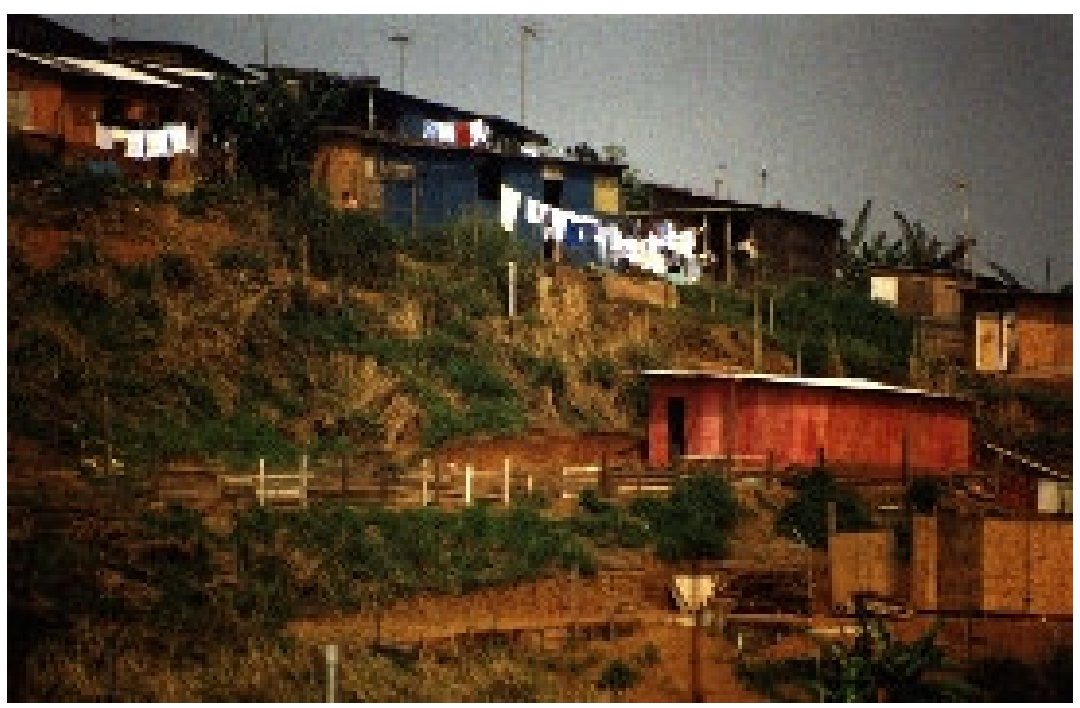

Figura 22 - Barracos construídos em área de risco geológico no morro Santa Maria, Santos. Foto do autor, 1999.

58 Lei $N^{\circ} 3.531$, de 16 de abril, de 1968 - Normas Ordenadoras e Disciplinadoras da Urbanização e da Preservação da Paisagem Natural dos Morros de Santos.
Por outro lado, durante esta etapa e sobretudo nas décadas de 70 e 80, as ocupações em manguezais e várzeas tiveram um crescimento espantoso. Conforme SERRANO (1991: 32), "As favelas se disseminaram pelos municípios de Santos, São Vicente, Cubatão e Guarujá. Além dos morros de Santos e Guarujá e da Serra do Mar em Cubatão foram invadidos mangues em Guarujá, Cubatão e São Vicente, os Diques da Ilha de São Vicente (Zona Noroeste), além das áreas livres na planície. Os diques haviam sido construídos pelo Departamento Nacional de Obras Sanitárias (DNOS) para recuperar mangues e terras baixas e permitir o parcelamento urbano".

A tipologia adotada nas favelas de planície, como nas encostas, é o barraco de madeira, com acabamento mais tosco que o chalé tradicional e posteriormente o barraco de alvenaria, coberto por telhas de fibro-cimento. São autoconstruções extremamente simples, geralmente constituídas de um programa arquitetônico mínimo, em dois ou três cômodos, em que a sala quase sempre serve como dormitório.

Quanto à questão fundiária, as favelas em áreas de manguezais eencontram-se em áreas da União (ver Figura 23), conhecidas como "terrenos de marinha". São faixas ao longo dos canais do estuário e dos córregos que nele desembocam, as quais não foram ocupadas por atividades portuárias e delimitavam áreas anteriormente utilizadas para atividades agrícolas.

Como lembrou SERRANO (1991), na década de 1950 o DNOS executou uma rede de diques na Zona Noroeste de Santos e em São Vicente, visando possibilitar atividades agrícolas e assentamentos residenciais em áreas, 
anteriormente, totalmente inundáveis. Com o declínio das atividades agrícolas, a partir da década de 1970, as comportas dos diques deixaram de passar por manutenção e estes passaram a ser ocupados por barracos, surgindo, então, as primeiras favelas em palafitas ${ }^{59}$.

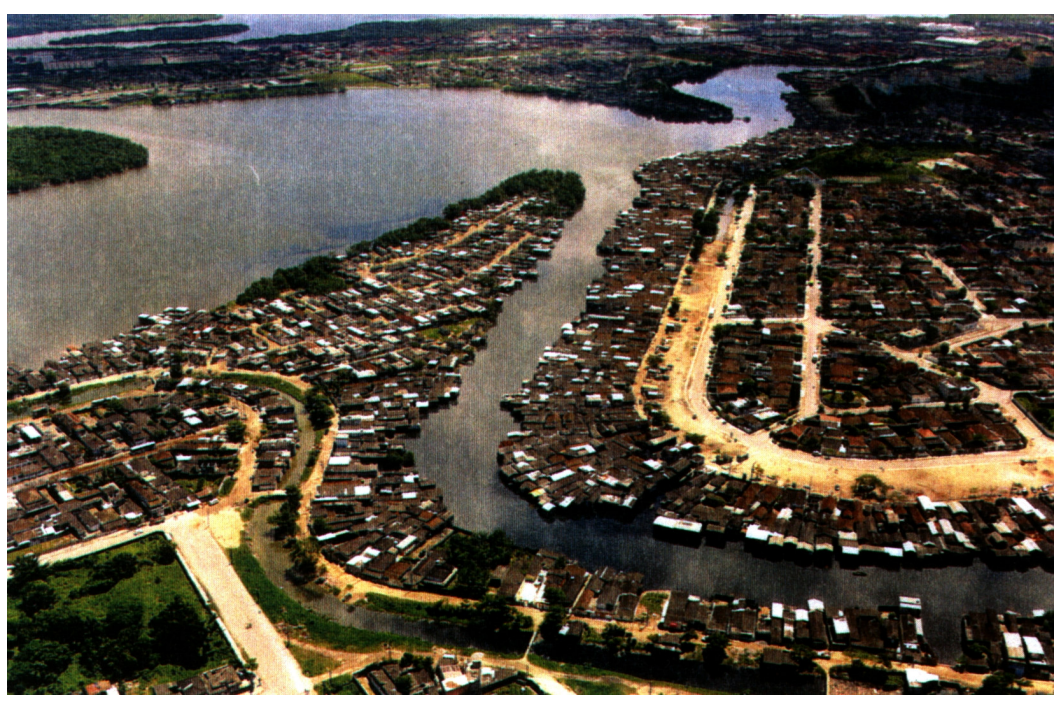

Figura 23 - Favelas típicas das margens do Estuário, com barracos em palafitas. A esquerda Dique do Sambaiatuba - São Vicente - a direita, Dique da Vila Gilda - Zona Noroeste de Santos. Fonte: Arquivo da Secretaria de Planejamento da Prefeitura de São Vicente, 1999.

Vale ressaltar, e este é um ponto central do presente trabalho, que essas "áreas de marinha" não eram objeto de

59 Barracos em palafitas são construídos sobre estacas de madeira, geralmente utilizando pneus usados como forma de estabilização das mesmas, e interligados por passarelas constituídas de tábuas reutilizadas, sobre mangues e áreas de maré, em geral (ver Figura 24). nenhuma legislação de uso do solo, e seus antigos foreiros $^{60}$, acabaram desinteressando-se por elas, em virtude do declínio da atividade agrícola e conseqüentemente de não possuírem valor imobiliário significativo. Portanto, eram áreas disponíveis para habitação das classes mais pobres, ainda que sem qualquer infra-estrutura e de difícil acesso.

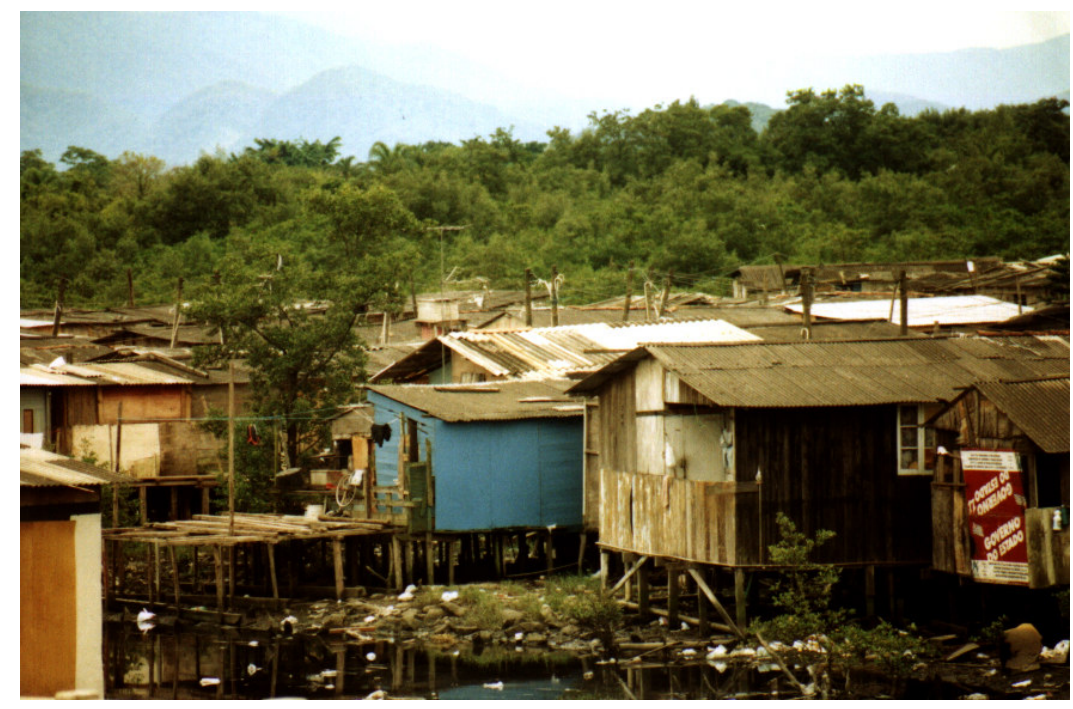

Figura 24 - Palafitas sobre a maré, na favela do Marinheiro, junto à Rodovia Piaçaguera-Guarujá. Foto do autor, 2002.

\footnotetext{
${ }^{60}$ Foreiro é o titular do aforamento, instrumento pelo qual a União cede suas áreas de marinha. Em que pese este caráter precário de posse, o aforamento tem valor de título e igualmente a uma escritura de propriedade deve seguir um rito específico para a transmissão entre os foreiros que se sucedem.
} 

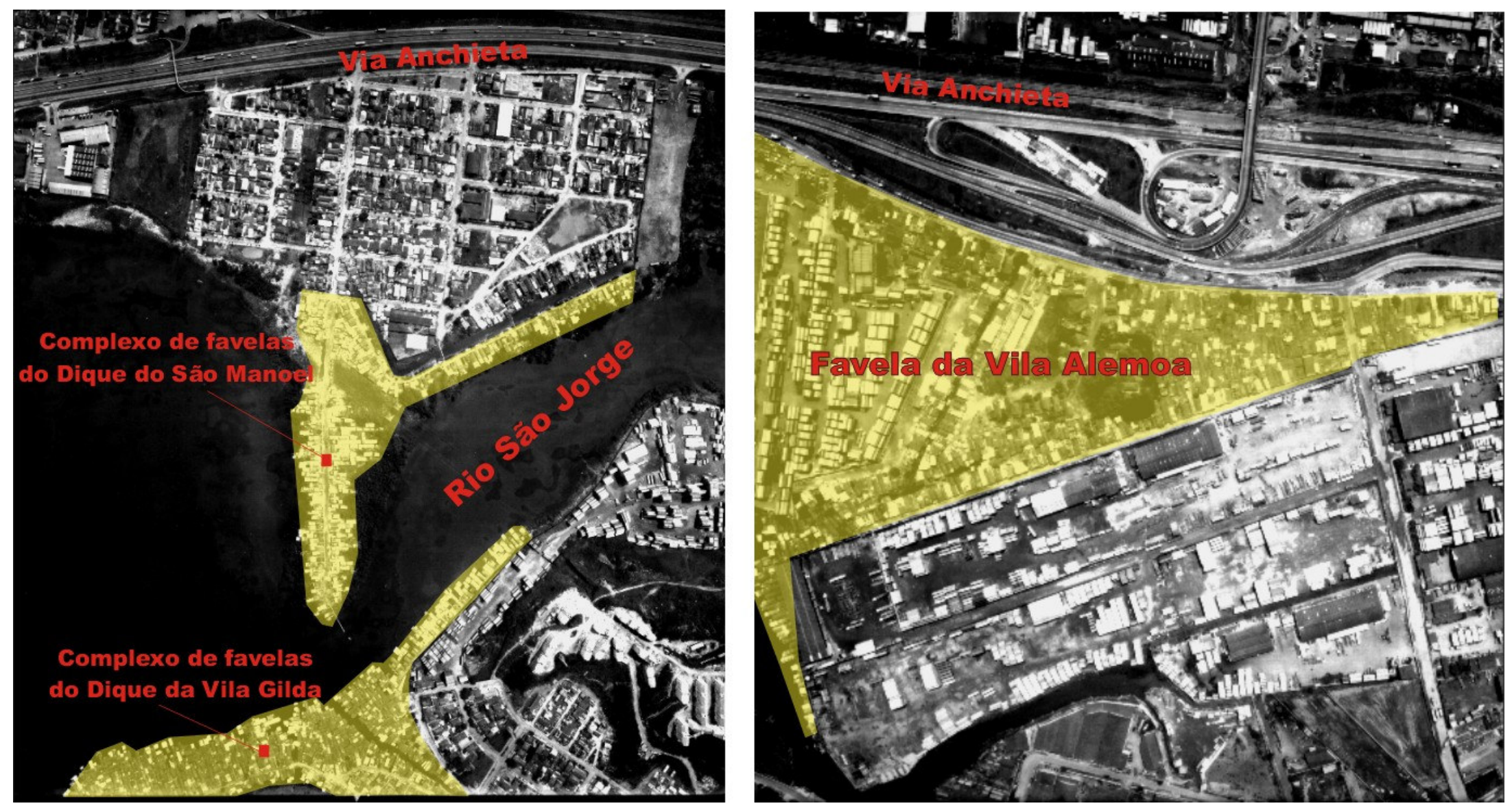

Figura 25 - Foto aérea de conjunto de favelas em áreas inundáveis, em terrenos de marinha, na Zona Noroeste de Santos (ver Mapa 1). Fonte: Eletropaulo, 1997. 
No Período Desenvolvimentista outra forma importante de acesso à habitação para as classes trabalhadoras continuou sendo o cortiço, cujo surgimento intensificou-se durante a era Vargas. Neste aspecto, a região próxima ao centro de Santos, inclusive áreas nos morros, continuou a abrigar este tipo de moradia.

Da mesma forma que ocorria com os cortiços da região central, no final do século XIX, os cortiços deste período estabeleceram-se em antigos casarões ${ }^{61}$, ou em fileiras de barracos de madeira ou alvenaria, construídos em seus quintais ou, menos comumente, nos fundos de atividades comerciais. O único tipo de cortiço que desapareceu foi o cortiço em cocheiras. Os porões dos casarões também foram ocupados, em condições extremamente insalubres, devido à alta umidade e falta de ventilação. Na verdade, a existência dos cortiços na RMBS continua, até hoje, a ser um fenômeno quase que exclusivo de Santos.

Segundo BONDUKI (1991: 234), esta intensificação durante a era Vargas tem raízes na Lei do Inquilinato, que congelou o valor dos aluguéis formais. Este autor escreveu:

"Finalmente, merece referencia o grupo dos sublocadores, de grande importância na formação de cortiços 'casas de cômodos'. Aproveitando-se da possibilidade de pagar aluguéis antigos62, certos locatários, especializados em adaptar casarões para o rentável negócio de alugar cômodos de cortiços, sairam-se muito bem. Apoiando-se na Lei do Inquilinato, pagavam valores irrisórios aos

61 Desta vez não são mais cocheiras e casarões coloniais que se transformaram em cortiços, mas antigas residências do Período do Café, onde habitavam famílias de alta renda, que acabaram por mudarse para bairros próximos às praias.

${ }^{62}$ Anteriores ao congelamento. proprietários e, por vezes, mantinham com seus inquilinos de baixa renda relações informais de locação, baseadas na violência e coerção, que lhes facilitava burlar a legislação".

Nos cortiços, a relação entre habitantes e proprietários permaneceu basicamente a mesma do final do século XIX, ou seja, existe a figura do intermediário, chamado de "dono da chave", que subloca os cômodos, porões e barracos, por valores próximos aos do mercado imobiliário formal. Neste aspecto pode-se verificar outra relação perversa.

Pelo fato dessas famílias de baixa renda não reunirem condições de comprovação de rendimentos e não possuírem fiadores, estas não podem se habilitar ao mercado formal. Então, acabam por submeter-se a valores locatícios extremamente altos, para habitar em condições bastante precárias. A relação com o "dono da chave" não passa pela mediação do poder público. É sempre uma relação tensa e violenta. $A$ inadimplência não é tolerada. $A$ falta de pagamento é sempre punida com o despejo sumário.

Há que se destacar que, ao contrário das favelas nas várzeas e manguezais, ou dos parcelamentos irregulares nos morros, os cortiços encontram-se em área da cidade servida satisfatoriamente por infra-estrutura urbana e equipamentos públicos, além de estarem em local dotado de uma boa rede de setor terciário. Como forma de intervir nessa questão, a Prefeitura de Santos propôs e aprovou uma lei de Locação Social, em 1996, regulamentando parte da Lei das Zonas Especiais de Interesse Social - ZEIS - Lei Complementar $\mathrm{N}^{\circ}$ 53, de 15 de maio de 1992. 
Essa lei definia um perímetro de intervenção, denominado ZEIS III, equivalente à área de maior concentração de cortiços na cidade, segundo avaliação do início daquela década. Essa área abrangia 24 quarteirões, em partes de bairros periféricos ao Centro: Paquetá, Vila Nova e Vila Mathias.

$\mathrm{Na}$ verdade, com a criação desse instrumental a municipalidade implantou alguns empreendimentos habitacionais para moradores de cortiços na área de ZEIS III. No entanto, esses empreendimentos foram em pequeno número, em função das dificuldades de financiamento que a municipalidade encontrou, por não haver, à época, programas específicos a nível estadual e federal.

Porém, em 2000 a Companhia de Desenvolvimento Habitacional e Urbano do Estado de São Paulo - CDHU iniciou estudos para o estabelecimento de um programa piloto de recuperação de áreas de cortiços, em Santos.

A situação dos cortiços em Santos, ao final do Período Desenvolvimentista, pode ser avaliada, ainda que de maneira amostral, pela análise dos dados de pesquisa realizada pela COHAB-St, em 1996, pela extinta Coordenadoria de Pesquisa Social. O órgão definiu uma área de intervenção, visando implantar um programa municipal de locação social, baseado na legislação municipal aprovada naquele ano.

A COHAB-St passou, então, a levantar os cortiços, denominados Habitações Coletivas de Aluguel - HCA, existentes nesse perímetro, e chegou ao número de 142 , abrigando 1.068 famílias, utilizando-se para isto do conceito de cortiço adotado pela Prefeitura de São Paulo. Em outra etapa do trabalho, expandindo a área para 131 quarteirões, abrangendo inteiramente o Centro e os bairros já citados, foram identificados mais 148 cortiços, somando, ao todo 290 HCA (ver Figura 26).

No perímetro da ZEIS III, a média por quarteirão era de 5,92 HCA, e sua maior concentração estava na área contígua ao Mercado Municipal. Destes imóveis, 8,46\% tinham uso misto e $87,30 \%$ eram casas de alvenaria, em sua maioria casas de arquitetura eclética, das primeiras décadas do século XX, com elevada qualidade arquitetônica, mas péssimo estado de conservação. Desses imóveis, 52,80\% tinham porões utilizados como moradia. Outro padrão muito comum era a subdivisão interna dos cômodos, muitas vezes utilizando-se madeira.

Um bom indicador das condições de salubridade dos imóveis foi a relação de número de banheiros por unidade, cuja média era de 2,62 por HCA, para uma média de 7,52 famílias por imóvel e 2,60 moradores por cômodo. Quanto à questão econômica, verificou-se que a média do valor correspondente ao aluguel, por cômodo era de $\mathrm{R} \$ 182,86$ mensais, em valor da data da pesquisa.

Quanto ao projeto da CDHU, aquela companhia iniciou estudos para implantação de seu Programa de Atuação em Cortiços - PAC, em Santos, e para isso contratou um levantamento atualizado da situação dos cortiços na cidade. Ao mesmo tempo a mesma equipe responsável pelo levantamento elaborou um projeto urbanístico piloto, que poderá ser implantado na área de maior concentração de cortiços, a quadra frontal ao Cemitério do Paquetá, limitada pelas avenidas Dr. Cochrane, São Francisco, Conselheiro Nébias e rua Amador Bueno. 
Durante seis meses de trabalho, uma equipe coordenada pelo arquiteto Luiz Fernando de Almeida, professor da Faculdade de Arquitetura e Urbanismo da Universidade Católica de Santos, levantou um perímetro aproximado ao adotado na segunda etapa da pesquisa da COHAB-St, identificando 104 quarteirões em que existiam cortiços, com um número aproximado de 600 imóveis nestas condições (ver Figura 27).

O número total de famílias ainda está sendo tabulado pela CDHU, mas na quadra do projeto piloto foram contabilizadas 120 famílias, habitando 27 imóveis, o que nos fornece uma média de 4,44 famílias por unidade, número bastante inferior ao da pesquisa anteriormente citada. Se esta média for extrapolada para o total de HCA, atingiremos um número de 2.664 famílias. Adotando-se a média de 4 membros por família, bastante utilizada por técnicos das municipalidades da RMBS quando se trata de habitação sub-normal, alcançar-se-ía o número de 10.656 habitantes em cortiços na cidade, o que, segundo os números preliminares do Censo 2000, da Fundação IBGE, representa $2,55 \%$ da população vivendo em cortiços.

Os demais dados sobre a área em estudo deverão ser divulgados posteriormente, pela CDHU, mas em entrevista com o Prof. Luiz Fernando de Almeida pudemos obter alguns valores preliminares acerca de locação e renda. $O$ valor locatício médio, por cômodo está dentro da faixa entre $R \$ 200,00$ e $R \$ 300,00$, e os rendimentos familiares variam entre $R \$ 150,00$ e $R \$ 1.000,00$, aproximadamente.

Analisando-se as duas pesquisas, e a documentação existente sobre o assunto, sobretudo a obra de LANNA (1996), pode-se afirmar sem qualquer dúvida que as habitações coletivas de aluguel são, há mais de um século, uma alternativa habitacional decorrente da exclusão social em Santos, com significativo peso no universo dos que vivem em submoradias na cidade.

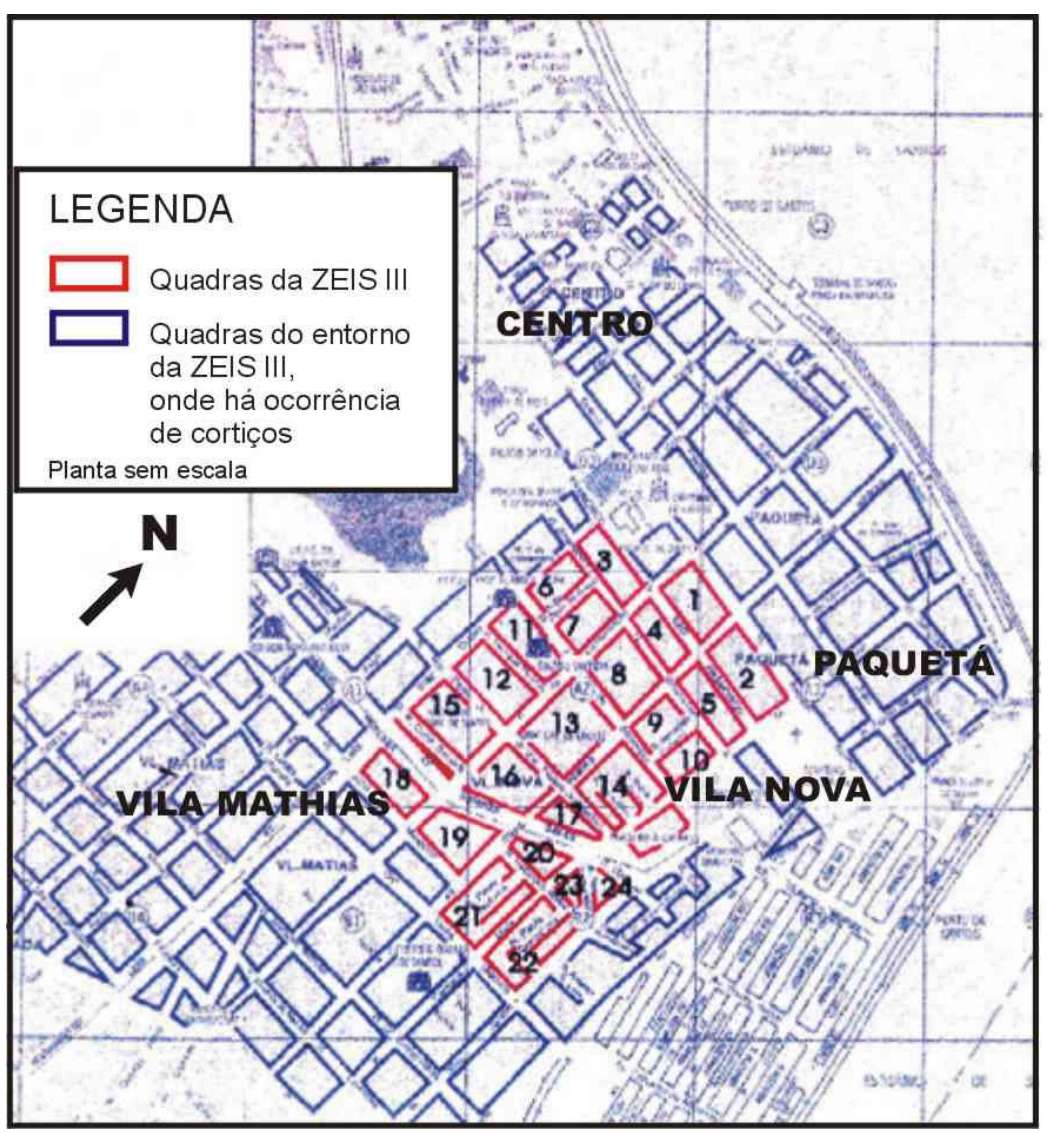

Figura 26 - Quadras objeto das duas etapas da pesquisa em cortiços da COHAB-St, 1996. Fonte: COHAB-St, Habitações Coletivas de Aluguel - Arrolamento de Imóveis, 1996. 
Ressalta-se ainda que no Período Desenvolvimentista consolidou-se o padrão do auto-empreendimento como forma principal de acesso à moradia para a população de baixa renda, em todo o país e, na Baixada Santista não poderia ser diferente, como se pôde ver ao analisar-se a PCV-98. A esse respeito, apontou BONDUKI (1998: 308),

"Ao contrário de todas as outras condições de ocupação (aluguel, cessão), apenas a casa própria auto-empreendida permite que a família possa incorporar trabalho e recursos para remoldar e melhorar permanentemente o espaço físico, de modo que este reflita e expresse o cotidiano familiar. Na casa alugada ou cedida, é a própria família que se adapta - seus hábitos, costumes e modo de morar, assim como seus objetos - a cada moradia que consegue obter. Isto explica porque parte significativa da população de baixa renda prefere a casa auto-empreendida à casa própria padronizada nos conjuntos habitacionais construídos por órgãos governamentais".

Mais adiante o autor completou (1998: 320),

"Quanto mais este processo informal de 'resolução' do problema habitacional avançou, impulsionado no inicio, como vimos, pela crise de moradia dos anos 40 e depois ganhando dinâmica própria, mais fortemente passou a atingir regiões localizadas em áreas de proteção ambiental, como mananciais, mangue, beiras de córregos e encostas. Era uma decorrência natural do padrão periférico de crescimento urbano, baseado na ocupação especulativa da terra e numa expansão horizontal ilimitada. Analises realizadas ainda nos anos 30 e 40, em eventos como o I Congresso de Habitação e as Jornadas de Habitação Econômica, previram o desastre futuro, que se manifesta hoje sobretudo na depredação ambiental e dificuldade de deslocamento".

Por fim, a autoconstrução em favelas ou loteamentos irregulares, ao lado da sublocação nos cortiços, passaram a ser as formas predominantes de acesso à moradia para a baixa renda, em face da conjuntura social durante o Período Desenvolvimentista. A Baixada Santista não fugiu à regra. Mais do que simplesmente isso, é a região do interior do Estado de São Paulo em que essas tipologias mais se desenvolveram, proporcionalmente ao total das moradias do mercado formal. 


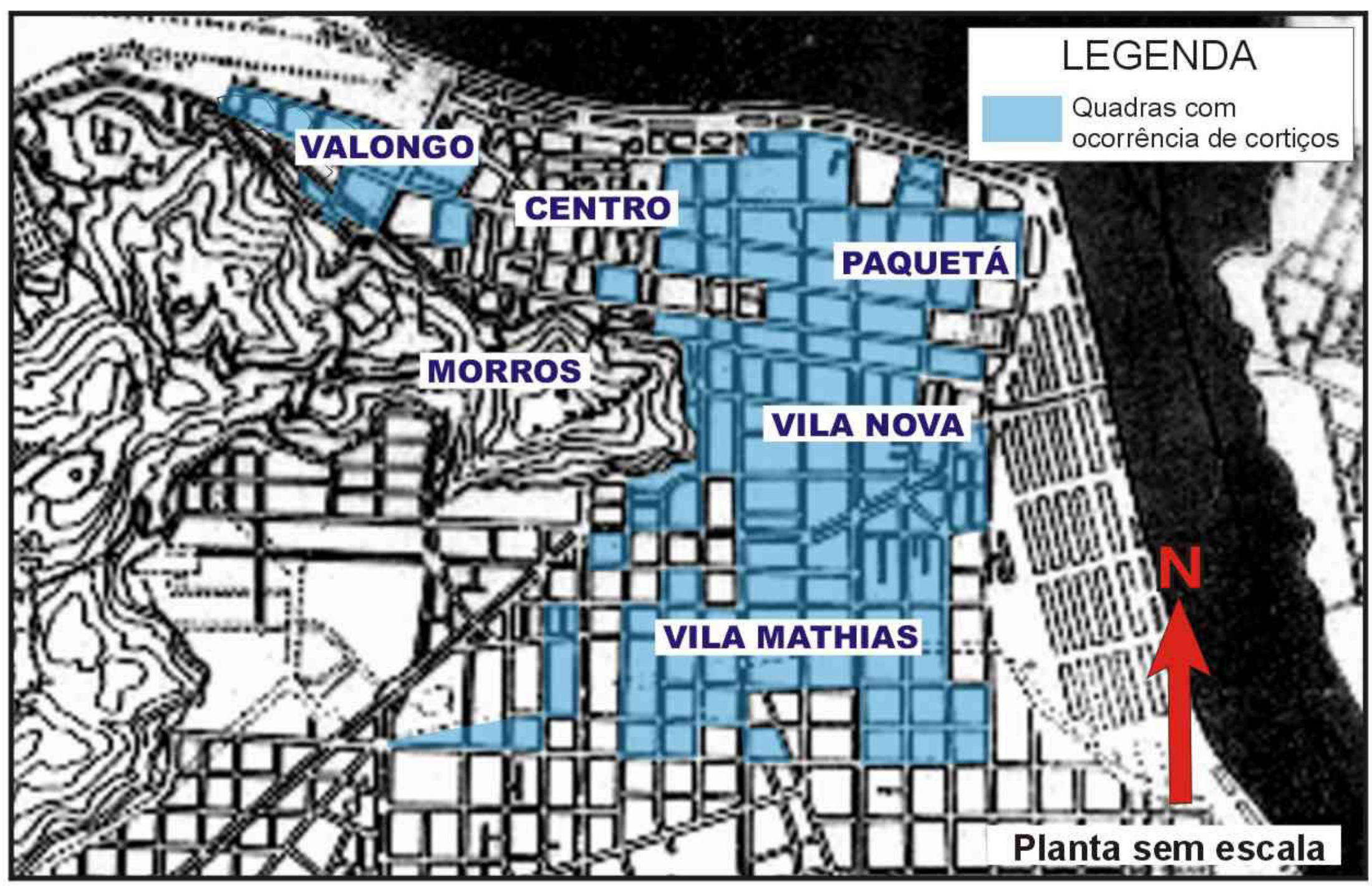

Figura 27 - Quadras onde foram identificados cortiços. Fonte: Levantamento CDHU, 2000. 


\subsection{Distribuição espacial atual das áreas de habitação subnormal nos municípios centrais da RMBS}

Para uma melhor compreensão da distribuição espacial atual das áreas de habitação subnormal nos municípios centrais da RMBS, são apresentadas ao fim deste item plantas dos municípios de Santos, São Vicente, Cubatão e Guarujá, onde estão assinaladas as favelas, loteamentos irregulares e áreas de concentração de cortiços. No caso de Santos a planta abrange unicamente a área insular, por serem as habitações subnormais na área continental em número bastante reduzido e possuírem tipologias e formas de acesso próximas a dos assentamentos rurais, sendo a pesca artesanal e a agropecuária as atividades preponderantes nesses núcleos.

Essas plantas estão associadas aos dados apresentados nas tabelas 11 a 15 , os quais foram obtidos por meio de levantamentos nos arquivos da COHAB Santista, das prefeituras de Santos, São Vicente e Cubatão, bem como da Empresa Municipal de Urbanismo do Guarujá - EMURG. Também foram realizadas visitas em campo e interpretação de fotos aéreas dos vôos mais recentes disponíveis nas municipalidades.

Nesse aspecto, cabe ressaltar que o conceito de habitação subnormal pode variar, com pequenas nuances, de municipalidade para municipalidade. Mas é unanimidade reconhecer, que os padrões para habitações subnormais na Baixada Santista são os seguintes:

a. Moradias auto-empreendidas em favelas, que podem estar em palafitas sobre os mangues, nas encostas dos morros ou Serra do Mar, em várzeas ou, menos comumente, em terrenos ou glebas dentro de áreas já urbanizadas das cidades ${ }^{63}$. Do ponto de vista fundiário, este padrão é definido por ocupações em áreas ociosas, públicas ou privadas.

b. Moradias auto-empreendidas em loteamentos irregulares típicos de periferia, nas encostas dos morros ou em várzeas. Do ponto de vista fundiário, este padrão é definido pela aquisição pela própria população de lotes não urbanizados, em localizações normalmente afastadas dos centros urbanos com baixo nível de organização espacial e ausência quase total de infraestrutura e serviços públicos essenciais.

c. Cômodos em cortiços, quase que exclusivamente na cidade de Santos, em casarões do final do século XIX ou princípio do século $X X$, localizados nos bairros e morros periféricos ao centro. Esses cômodos podem ser os da planta original do imóvel, adaptada ou não, com subdivisões; "casinhas" enfileiradas em quintais, nos fundos desses imóveis ou de edifícios com uso comercial; ou mesmo em porões subdivididos. Do ponto de vista do acesso, esse padrão é definido por sublocações informais, em sua maioria não regidas pela Lei do Inquilinato.

É importante ressaltar que o conceito de moradia subnormal pode variar conforme o contexto histórico ou até mesmo de

\footnotetext{
${ }^{63}$ Esse padrão é normalmente o resultado do fenômeno de urbanização ao redor de favelas pré-existentes, como no caso da Vila Santa Casa, no bairro Encruzilhada, em Santos. Esta favela, uma das mais antigas da Baixada, surgida na década de 1940, foi o resultado de ocupações em área ociosa, de propriedade da Santa Casa de Santos, numa época em que o sistema viário do bairro não estava totalmente implantado. Com o passar dos anos, o bairro foi sendo urbanizado, inclusive parte da própria favela, de maneira que a impressão que se tem hoje, é a de que a favela está "incrustada" em um bairro "normal" de classe média.
} 
região para região. A cerca desta questão, vimos em TASCHNER (1978):

"Os parâmetros aceitáveis de habitabilidade, em dado momento, são ditados essencialmente pelas concepções de vida dos estratos sociais a que pertencem os responsáveis pela formulação da política habitacional. Aliás percebeu-se que já não há muito sentido no estabelecimento de normas rígidas de aceitação ou rejeição de condições habitacionais - não existe acordo num conceito definitivo de 'mínimo'. O mínimo não representa o mesmo para cada camada social e para cada momento histórico" apud SERRANO (1991: 14).

Ou seja, como apontou SERRANO, comentando TASCHNER:

"A idéia de moradia socialmente aceitável estará na dependência de quem o formula. $O$ conceito do cientista que estuda o fenômeno pressupõe, por exemplo, padrões sanitários e de conforto que não tem a mesma importância para o morador que, por sua vez poderia ver sua moradia uma melhoria em relação à anterior: uma localização no espaço urbano que lhe dá maiores oportunidades de trabalho, uma ausência de custos que lhe permite alimentar, etc."

Assim, procurou-se adotar, neste estudo, um conceito de habitação subnormal semelhante ao utilizado pelos técnicos das prefeituras e órgãos públicos da RMBS, nos distintos levantamentos realizados sobre a questão.

A seguir, apresentamos tabelas com a população estimada dos assentamentos subnormais em Santos, São Vicente,
Cubatão e Guarujá, segundo os levantamentos realizados em cada município. No caso de Santos, vale destacar, também, que núcleos surgidos na metade da década de 1990 ainda não foram objeto de levantamentos sistemáticos pelos órgãos da municipalidade responsáveis por este tipo de pesquisa. Nesses casos, apresentou-se números aproximados de moradias, baseados em visita em campo efetuadas pelo autor, confrontadas a fotos aéreas, nos casos em que estas estão disponíveis.

Nas páginas posteriores às das tabelas, apresentou-se plantas com as manchas dos assentamentos subnormais desses municípios, segundo o tipo: favelas, cortiços e parcelamentos irregulares com nível precário de atendimento por infra-estrutura urbana e equipamentos públicos. 
Tabela 11

\section{Santos - Famílias em domicílios subnormais}

\begin{tabular}{|c|c|}
\hline NOME DO ASSENTAMENTO & $\begin{array}{l}\text { NÚMERO DE } \\
\text { FAMÍLIAS }\end{array}$ \\
\hline Vila Santa Casa* & 83 \\
\hline Estuário** & 90 \\
\hline Complexo do Dique da Vila Gilda & 3.241 \\
\hline Jardim Butantã & 162 \\
\hline Vila Alemoa* & 1.039 \\
\hline Vila Pantanal & 733 \\
\hline Caneleira III & 469 \\
\hline Vila dos Criadores & 199 \\
\hline Caminho da União São Manuel & 411 \\
\hline Morro Santa Maria & 134 \\
\hline Rua 1 - Nova Cintra ${ }^{\star \star \star \star}$ & 75 \\
\hline Altos da Vila Progresso (Vila César) ${ }^{* \star * *}$ & 125 \\
\hline Lomba da Penha* & 95 \\
\hline Campinho do Monte Serrat ${ }^{\star \star \star \star}$ & 60 \\
\hline Morro do Marapé & 20 \\
\hline Próprio Municipal do Saboó ${ }^{* \star *}$ & 45 \\
\hline Pantanal II (Morro Santa Maria) ${ }^{\star \star \star \star \star *}$ & 125 \\
\hline Cortiços $^{* \star \star \star *}$ & 2.664 \\
\hline TOTAL & 9.770 \\
\hline
\end{tabular}

Fonte: COHAB Santista, cadastro realizado em 1999, e outros órgãos da Prefeitura Municipal de Santos.

* Cadastro realizado em 2000.

** Cadastro realizado em 1996

*** Levantamento realizado em 1996 pela Administração Regional dos Morros.

**** Levantamento realizado em 2000 pela Coordenadoria de Morros. $* * * * *$ Dados do CDHU referentes a 2000.

$\star * \star \star \star *$ Dados obtidos por contagem de moradias efetuada pelo autor em 2000.

Obs.: O Complexo de favelas do Dique da Vila Gilda é composto pelos Caminhos São José, São Sebastião, da Divisa, da Capela, Vila Telma e Mangue Seco.
Tabela 12

\section{São Vicente - Habitantes em domicílios subnormais}

\begin{tabular}{|l|c|}
\hline \multicolumn{1}{|c|}{ NOME DA FAVELA } & $\begin{array}{c}\text { NÚMERO DE } \\
\text { HABITANTES }\end{array}$ \\
\hline Rio Branco & 1.400 \\
\hline Argentina 78/Rio da Avó & 2.927 \\
\hline México 70/Saquaré & 19.364 \\
\hline Miau* & 403 \\
\hline Sá Catarina de Moraes & 4.886 \\
\hline Dique Sambaiatuba/Batuíra/Santo Antônio & 7.694 \\
\hline Pompeba/Piçarro/Caxetas & 5.725 \\
\hline Quarentenário & 9.437 \\
\hline Nova São Vicente & 1.238 \\
\hline Mangue Seco & 1.336 \\
\hline TOTAL & $\mathbf{5 4 . 4 1 0}$ \\
\hline
\end{tabular}

Fonte: Secretaria de Planejamento da Prefeitura de São Vicente, estimados para 1997.

*Estimativa baseada em levantamento de 1994 
Tabela 13

\section{Cubatão - Habitantes em domicílios subnormais}

\begin{tabular}{|c|c|}
\hline NOME DO NÚCLEO* & $\begin{array}{l}\text { NÚMERO DE } \\
\text { HABITANTES }\end{array}$ \\
\hline Cota $500^{* *}$ & 5 \\
\hline Cota $400^{\star \star}$ & 682 \\
\hline Cota $200^{* *}$ & 5.971 \\
\hline Cota $95 / 100^{\star *}$ & 2.982 \\
\hline Pinhal do Miranda/Grotão** & 6.647 \\
\hline Morro do Mazargão**** & 1511 \\
\hline Fábrica da Sardinha - Pilões & 899 \\
\hline Água Fria** & 2.803 \\
\hline Vila São José (remanescente) ${ }^{\star * *}$ & 3.512 \\
\hline Forte Apache (Via Anchieta) & 37 \\
\hline Vila Esperança & 8.140 \\
\hline Vila Natal (invasão) & 518 \\
\hline Curtume & 281 \\
\hline Costa Muniz (invasão) & 571 \\
\hline Bolsão VII - Jardim Conquista & 318 \\
\hline Vila dos Pescadores & 8.140 \\
\hline Ilha Caraguatá (invasão) & 555 \\
\hline Favela do Papelão***** & 133 \\
\hline Sítio Capivari & 22 \\
\hline Sítio Areais & 62 \\
\hline Vila Feliz & 70 \\
\hline Via Anchieta (Pista Descendente - Km 55) & 199 \\
\hline Via Anchieta (Pista Descendente - TEDEP) & 40 \\
\hline Mantiqueira & 303 \\
\hline Raiz da Serra & 66 \\
\hline Vila Elizabeth (invasão) & 222 \\
\hline Hospital Ana Costa (invasão atrás) & 118 \\
\hline TOTAL & 44.807 \\
\hline
\end{tabular}

Fonte: Secretaria de Planejamento da Prefeitura Municipal de Cubatão.

*Terminologia adotada pelos técnicos de Cubatão.

**Levantamento realizado em 2000

${ }^{* * *}$ Levantamento realizado em 1999
**** Levantamento realizado em 1998

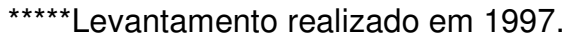

Obs.: Os demais núcleos tiveram sua população estimada, para 2000.

\section{Tabela 14}

\section{Guarujá - Habitantes em domicílios subnormais}

\begin{tabular}{|c|c|}
\hline NOME DO ASSENTAMENTO & $\begin{array}{l}\text { NÚMERO DE } \\
\text { HABITANTES }\end{array}$ \\
\hline Rã/Sossego/Areião**** & 7.386 \\
\hline Prainha*** & 5.118 \\
\hline Jardim Bela Vista & 1.410 \\
\hline Jardim Três Marias & 232 \\
\hline Vila Baiana & 5.785 \\
\hline Morro do Engenho & 2.117 \\
\hline Cidade de Deus/Vila Edna** & 4.372 \\
\hline Vila Júlia & 1.400 \\
\hline Marinheiro & 2.380 \\
\hline Santa Clara** & 2.917 \\
\hline Vila da Noite ${ }^{\star *}$ & 2.733 \\
\hline Cachoeira ${ }^{\star \star \star \star \star}$ & 5.499 \\
\hline João Guarda & 2.457 \\
\hline Jardim Primavera ${ }^{\star \star \star}$ & 5.555 \\
\hline Vila Santa Rosa*** & 2.764 \\
\hline Vila Lígia*** & 537 \\
\hline Vietnã/Marezinha**** & 575 \\
\hline Santa Madalena & 340 \\
\hline Avenida Atlântica & 300 \\
\hline Vila Zilda & 3.510 \\
\hline $\mathrm{Km} 8$ & 113 \\
\hline Praia do Perequê & 2.073 \\
\hline Santa Cruz dos Navegantes ${ }^{\star *}$ & 5.018 \\
\hline Favela do Caixão & 1.670 \\
\hline Jardim das Flores & 615 \\
\hline Vila da Morte & 1.232 \\
\hline Morrinhos IV & 2.192 \\
\hline Morro do Bio & 520 \\
\hline Avenida Acaraú & 370 \\
\hline
\end{tabular}


Legislação urbanística e segregação espacial nos municípios centrais da Região Metropolitana da Baixada Santista

\begin{tabular}{|c|c|}
\hline Perequê & 9.200 \\
\hline Morrinhos III & 3.772 \\
\hline Maré Mansa & 1.176 \\
\hline Vila Sapo** & 331 \\
\hline Vila Funchal & 314 \\
\hline Favela do Padre ${ }^{\star \star}$ & 572 \\
\hline D.E.R. ${ }^{\star *}$ & 158 \\
\hline Morro Outeiro & 325 \\
\hline Cidade Atlântica I I** & 538 \\
\hline Cidade Atlântica I*** & 350 \\
\hline Vila do Perigo*** & 299 \\
\hline Nova República II** & 628 \\
\hline Nova República I** & 543 \\
\hline Chaparral/Chaparralzinho & 1.690 \\
\hline Prainha Branca & 853 \\
\hline Praia do Góes & 300 \\
\hline Mangue Seco*** & 1.730 \\
\hline Vila Selma** & 517 \\
\hline Mar e Céu & 3.045 \\
\hline Vila Áurea & 360 \\
\hline Deus-Me-Deu & 205 \\
\hline Viela Transmissão & 400 \\
\hline Jardim Conceiçãozinha & 4.536 \\
\hline TOTAL & 103.032 \\
\hline
\end{tabular}

Tabela 15

Total de habitantes em habitações subnormais nos municípios centrais da RMBS

\begin{tabular}{|l|c|c|}
\hline MUNICÍPIO & $\begin{array}{c}\text { NÚMERO DE } \\
\text { HABITANTES }\end{array}$ & $\begin{array}{c}\text { RELAÇÃO COM A } \\
\text { POPULAÇÃO TOTAL (\%) }\end{array}$ \\
\hline Santos ${ }^{*}$ & 39.080 & 9,35 \\
\hline São Vicente & 54.410 & 17,98 \\
\hline Cubatão & 44.807 & 41,52 \\
\hline Guarujá & 103.032 & 38,86 \\
\hline TOTAL & $\mathbf{2 4 1 . 3 2 9}$ & $\mathbf{2 2 , 0 7}$ \\
\hline
\end{tabular}

*Em Santos, os levantamentos foram efetuados por diferentes órgãos, e também pelo autor. Por tal razão os dados são fornecidos em diferentes bases, por vezes em número de famílias ou números de moradias. Por isso utilizaou-se a média de 4 habitantes por família, comumente adotada pelos técnicos da região, com base em dados dos censos demográficos, para homogeneizar a contagem final.

*Levantamento realizado em 2000

**Levantamento realizado em 1999

***Levantamento realizado em 1998.

****Levantamento realizado em 1997

${ }^{\star \star \star \star \star \star} A$ parte plana do Cachoeira já foi objeto de levantamento, a parte de encosta está em andamento.

Obs.: Os demais assentamentos tiveram sua população estimada por meio de fotos aéreas de 1997. 


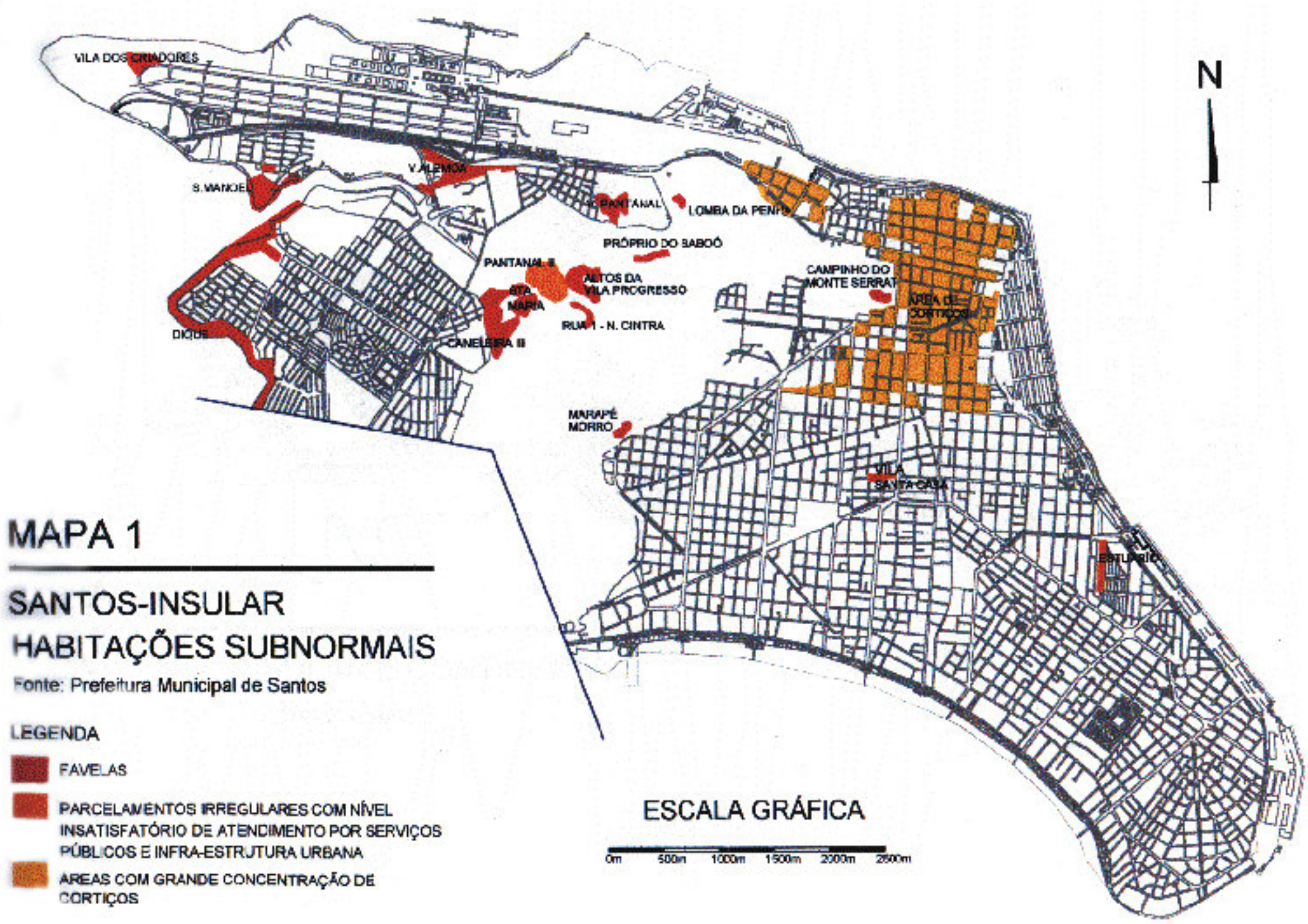


Legislação urbanística e segregação espacial nos municípios centrais da Região Metropolitana da Baixada Santista 


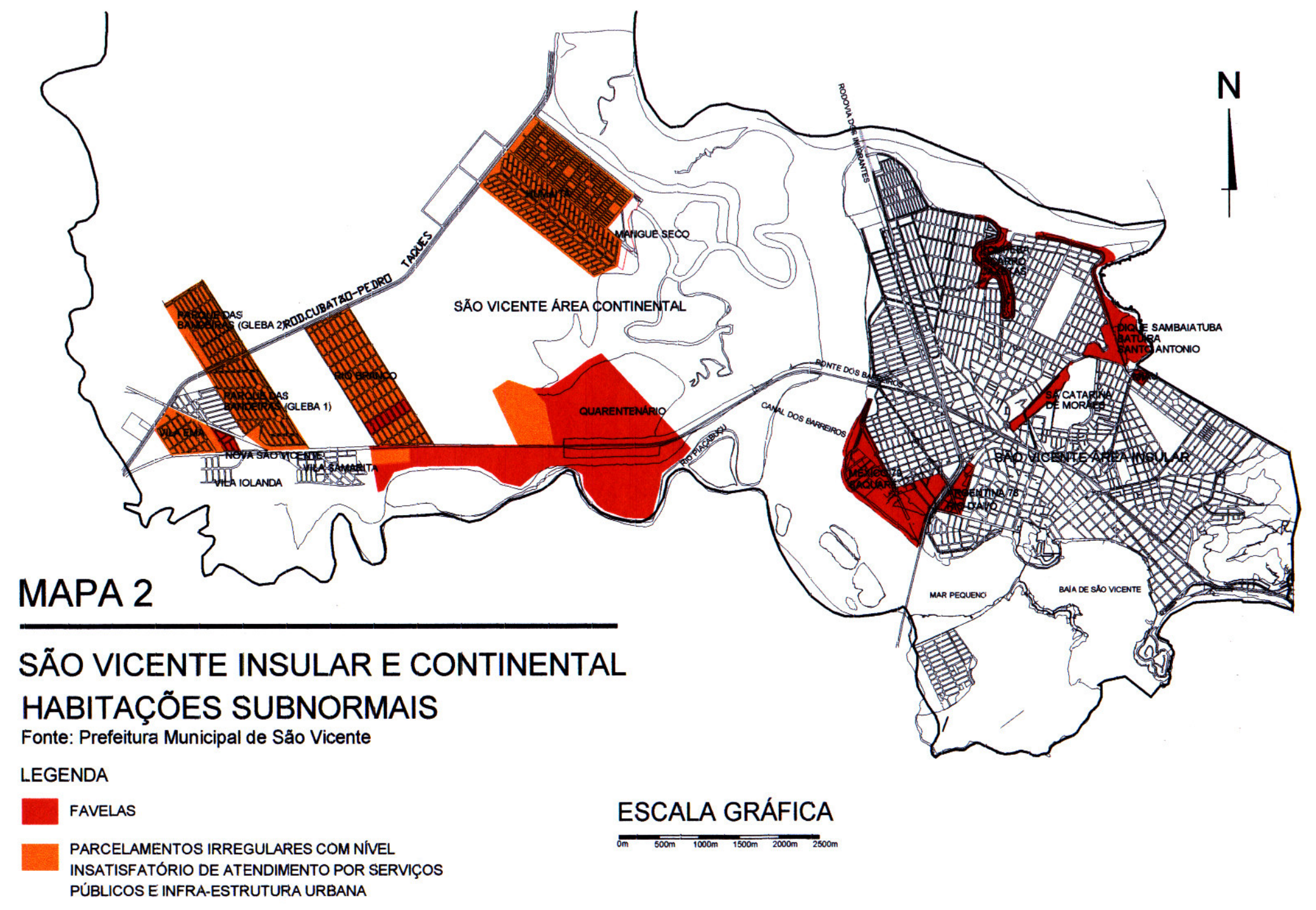


Legislação urbanística e segregação espacial nos municípios centrais da Região Metropolitana da Baixada Santista 


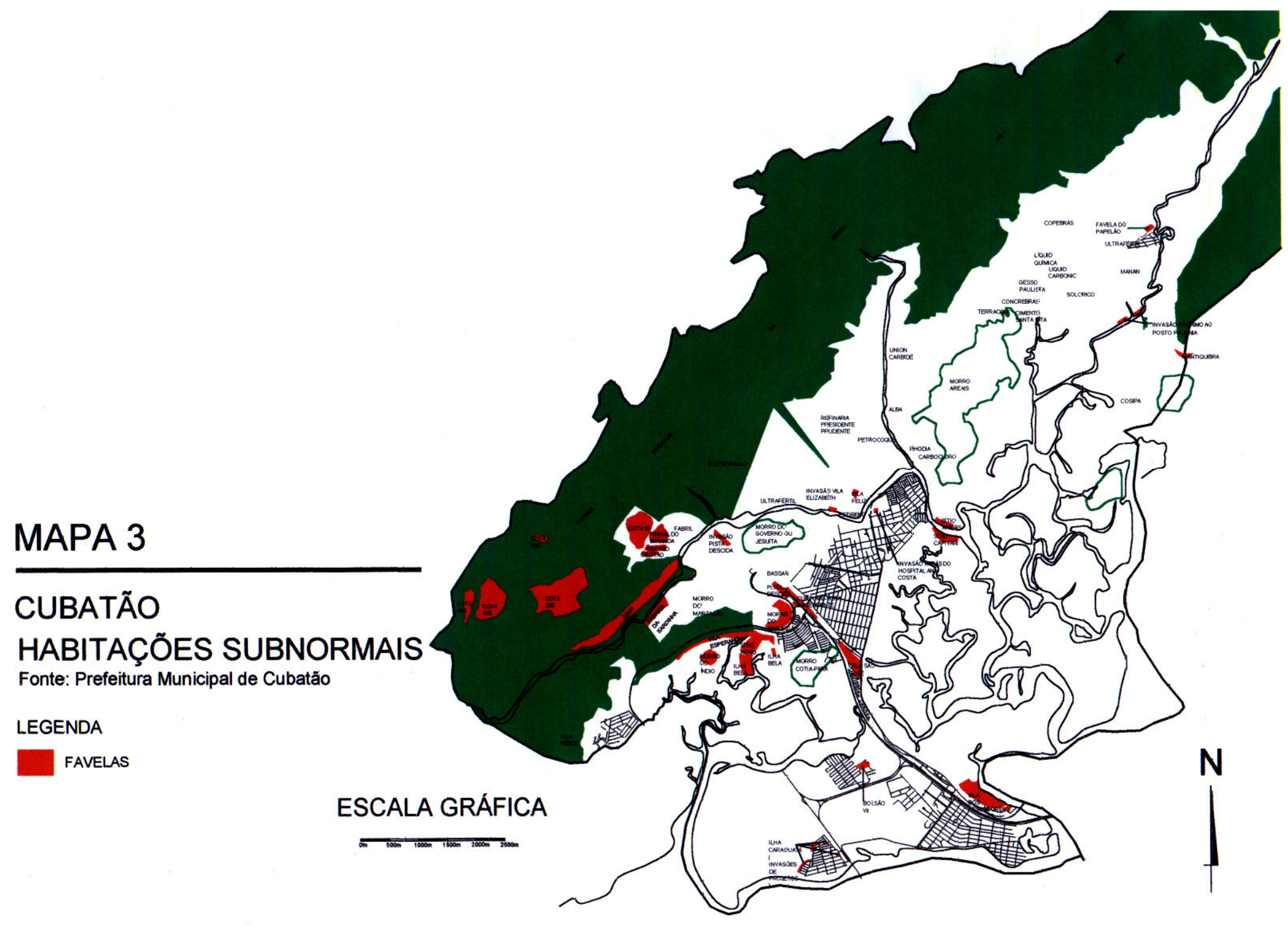


Legislação urbanística e segregação espacial nos municípios centrais da Região Metropolitana da Baixada Santista 


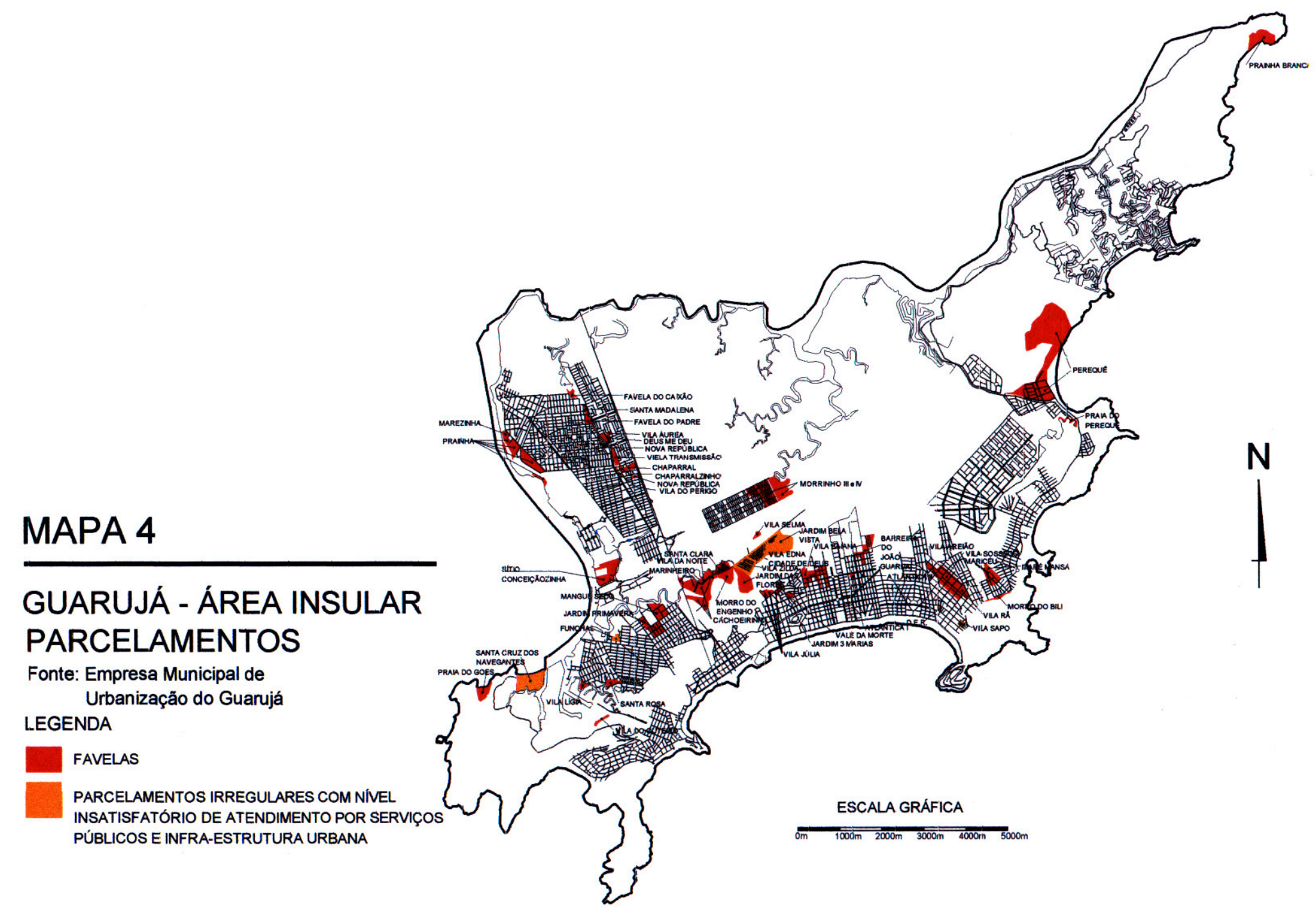


Legislação urbanística e segregação espacial nos municípios centrais da Região Metropolitana da Baixada Santista 


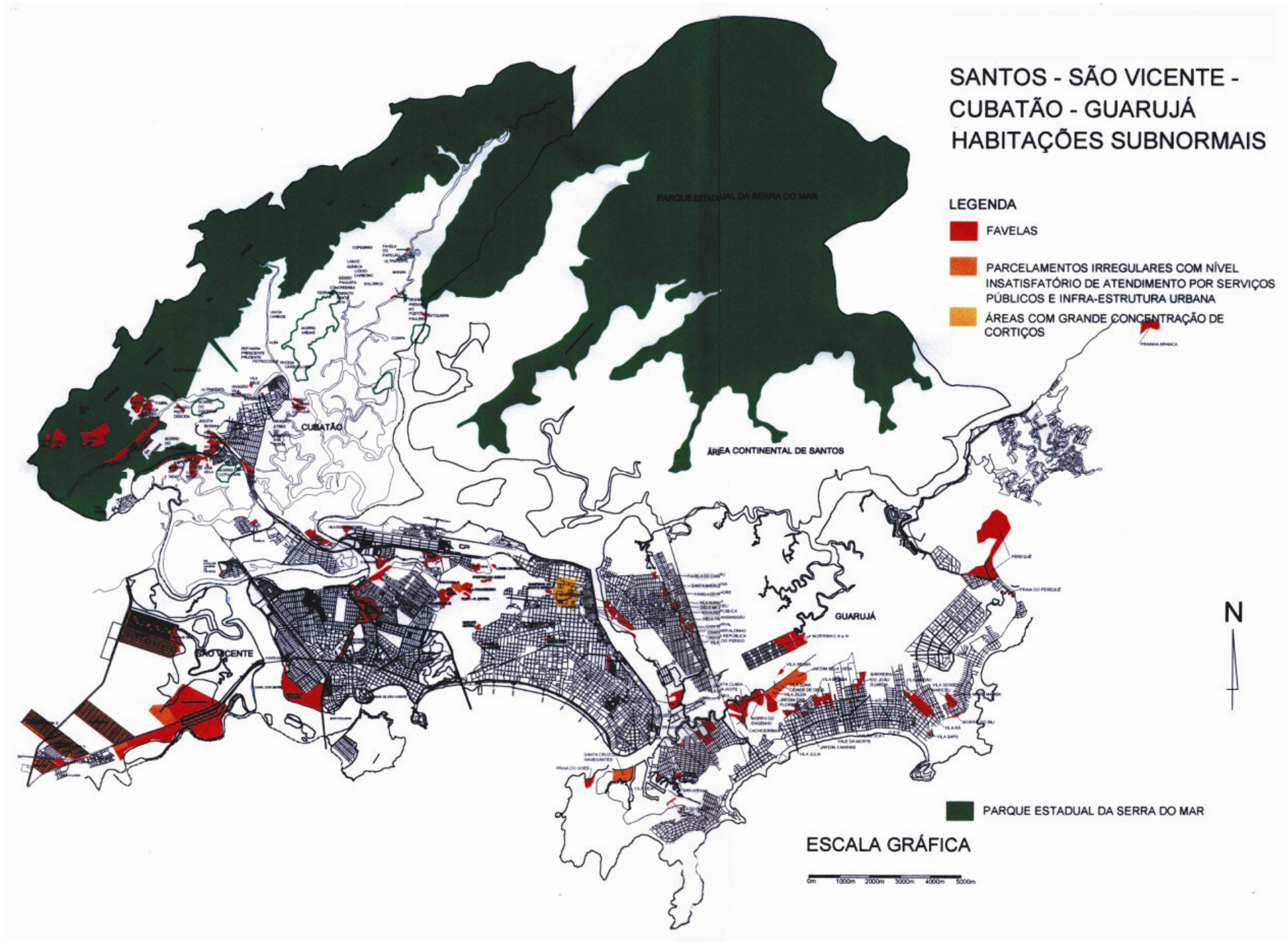


Legislação urbanística e segregação espacial nos municípios centrais da Região Metropolitana da Baixada Santista 


\subsection{Considerações sobre o processo de segregação espacial nos municípios centrais da RMBS}

Analisando-se os dados apresentados no item anterior há uma questão que se deve considerar e que salta aos olhos pelas visitas em campo realizadas. Se forem comparados os critérios para enquadramento dos assentamentos na condição de subnormal, sobretudo nos casos de Guarujá e São Vicente, parece haver um rigor excessivo na classificação dos assentamentos. Este rigor faz com que áreas anteriormente surgidas na condição de subnormalidade, mas hoje quase inteiramente atendidas por infra-estrutura urbana e equipamentos sociais, ainda sejam contabilizadas como assentamentos subnormais.

Pode-se supor que este rigor técnico está impregnado de uma certa visão ideológica, pela qual apresentar um quadro mais grave do que o real pode funcionar como pretexto de isenção ao poder público local, quanto à sua responsabilidade de agir mais efetivamente sobre a questão do déficit de habitabilidade. Esta isenção seria decorrente de uma situação de tal gravidade, que pouco ou nada poderia ser feito sem o apoio de outras esferas de governo.

Assim, comparando-se os dados da Tabela 15, com os dados apresentados na Tabela 9 - Déficit Habitacional da RMBS - 1998, verifica-se que o número de habitantes em moradias subnormais é substancialmente superior ao déficit estimado pelas municipalidades, mesmo levando-se em conta o descompasso entre as distintas datas dos levantamentos e o ano de referência utilizado na Tabela 9.

Esse diferencial pode ser explicado pelo fato de que em todos os levantamentos municipais os assentamentos que já foram objeto de intervenção, seja esta parcial ou em fase final de urbanização, foram incluídos das estatísticas, gerando uma distorção que poderá levar a uma leitura equivocada da situação habitacional na RMBS.

Assim, por exemplo, em Guarujá, a antiga favela da praia de Santa Cruz dos Navegantes, também conhecida como "Pouca Farinha", com 5.008 habitantes, já está quase que totalmente urbanizada, segundo informou técnico da EMURG, restando apenas a instalação de rede de esgoto atualmente recolhido em fossas sépticas - bem como um reduzido número de palafitas sobre a maré, que ainda não foram relocadas.

Dessa forma, resta muito pouco para que esse núcleo esteja definitivamente integrado à malha da cidade formal. Muitos outros exemplos semelhantes podem ser encontrados, em todos os municípios e por essa razão os números da Tabela 9 dão uma leitura mais aproximada da situação habitacional da baixa renda na RMBS, em termos de população alvo para projetos habitacionais. No entanto, os dados das tabelas 11 a 15 dão um painel mais completo da segregação espacial na Baixada, ao final do século XX.

De qualquer maneira, é possível afirmar que os efeitos da segregação espacial foram profundos nos municípios centrais da RMBS. Da mesma forma, as políticas públicas voltadas á questão da produção de habitação de interesse social foram ineficazes.

No entanto, essa ineficácia parece pouco ter sensibilizado os poderes locais e demais esferas de governo, todos responsáveis pela questão, pois quase nunca trataram o assunto com a prioridade social adequada. 
Há ainda uma profunda desarticulação entre os municípios da RMBS, quando se trata de enfrentar o problema da habitação. Na verdade, a COHAB Santista é uma companhia majoritariamente pertencente ao município de Santos, mas outros municípios da região possuem cotas da empresa. Tal fato nunca foi suficiente, com raríssimas exceções, para que houvesse uma verdadeira ação em conjunto na produção de projetos habitacionais de cunho metropolitano.

É possível que na medida em que a RMBS for institucionalizada a habitação de interesse social passe a fazer parte da agenda metropolitana. No entanto, até o momento não há indício de que isso venha a acontecer. Sobretudo porque não há mudança concreta no relacionamento institucional entre COHAB-St e CDHU, por exemplo. Na verdade, a atuação do CDHU - órgão estadual responsável pela política habitacional - é marcada pelo relacionamento totalmente fragmentado, vertical e desarticulado das áreas de habitação dos municípios da Baixada.

As demais faces da questão da segregação espacial serão aprofundadas nos capítulos 4 e 5 deste trabalho. São elas, a questão da legislação urbanística, como elemento de aprofundamento da segregação e a elevação do valor imobiliário nas áreas próximas á orla dos municípios centrais, onde a oferta de infra-estrutura urbana e equipamentos sociais é mais abundante. São questões interdependentes, cujas origens e formações estão intimamente ligadas, sendo seu estudo fundamental, para que se possa entender em profundidade os fatores geradores da segregação espacial na RMBS. 
Legislação urbanística e segregação espacial nos municípios centrais da Região Metropolitana da Baixada Santista

4. A questão da terra no Brasil e a evolução da regulação urbanística nos municípios centrais da RMBS 
Legislação urbanística e segregação espacial nos municípios centrais da Região Metropolitana da Baixada Santista 


\begin{abstract}
"A chave da eficácia em demarcar um território social preciso reside evidentemente no preço. Lotes grandes, grandes recuos, nenhuma coabitação é fórmula para quem pode pagar. A lei, ao definir que num determinado espaço pode ocorrer somente um certo padrão, opera o milagre de desenhar uma muralha invisível e, ao mesmo tempo, criar uma mercadoria exclusiva no mercado de terras e imóveis".

ROLNIK (1997: 47).
\end{abstract}

Pouco se sabe do período anterior ao início da colonização portuguesa, mas acredita-se que as populações indígenas possuíam uma relação ambientalmente mais equilibrada com a terra, sobretudo em função da forma de fixação desses povos, em que as atividades de caça e pesca eram preponderantes à incipiente atividade agrícola existente. Não obstante, a relação dos povos indígenas com a terra era regida pela escassez ou abundância da caça e da pesca, que poderia obrigar as populações a procurar outros territórios.

Desse período não se pode encontrar vestígios de urbanização no Brasil, pois a relação entre nossos primeiros habitantes e a terra nunca possibilitou a fixação de núcleos habitacionais relevantes em nosso território, tal como ocorreu às civilizações pré-colombianas em outras partes do continente americano.

Por outro lado, mesmo antes do "descobrimento" grande parte das nossas terras já pertencia à Coroa Portuguesa, mais precisamente à Ordem de Cristo, cujo grão-mestre era o Rei, em função do tratado de Tordesilhas, celebrado entre Portugal e Espanha. Via colonização portuguesa, a regulamentação da propriedade da terra esteve submetida às Ordenações Afonsinas (1446) e posteriormente às Ordenações Manuelinas (1521).

Cabe ressaltar que no início da ocupação portuguesa houve um interesse marginal em um projeto rural de exploração de riquezas. Durante os primeiros séculos da colonização o caráter centralizador das capitanias hereditárias, forma de divisão administrativa adotada pela coroa, não deu espaço para o surgimento de um poder público municipal substantivo.

Este período corresponde aos séculos XVI e XVII, quando a representação direta dos homens "bons" do povo era através das Câmaras de Vereadores e o regime de propriedade urbana dava-se pelas sesmarias e direitos de vizinhança.

Desde 1475 se não houvesse uso produtivo e "desbravamento" da terra, a sesmaria poderia ser cassada em definitivo. No Brasil, foi delegada em 1530, a Martim Afonso de Souza, a tarefa de colonizar a região onde hoje se localiza a Baixada Santista, bem como a permissão para nesta conceder sesmarias. Nas vilas as sesmarias denominavam-se datas e as Câmaras podiam conceder e cassar datas "a partir do rocio da vila"64.

No período em que as coroas de Portugal e Espanha estiveram unificadas, entre 1580 e 1640, o Brasil esteve

\footnotetext{
${ }^{64} \mathrm{O}$ rocio da vila era o espaço de uso comum da população, situado normalmente em sua periferia mais próxima, utilizado para o pastoreio de animais, por exemplo.
} 
sujeito às Ordenações Filipinas, que estabeleceram critérios para construir a cidade, como a distância mínima entre casas, quando as paredes laterais tivessem aberturas, por exemplo. É interessante destacar que nessa época a definição de urbano ou rural não estava vinculada à localização das moradias, mas sim ao tipo de acabamento. Se rústicas as edificações eram rurais e chamadas de casas, se bem acabadas eram urbanas e denominadas edifícios.

Segundo REIS FILHO, apud FRÚGOLI Jr. (2001), "As políticas urbanas iluministas pensavam o espaço de cada segmento social na cidade para melhor exercer seu controle, ao passo que uma marca do fenômeno urbano contemporâneo seria a indiferença para com os mais pobres".

De fato, como ensina REIS FILHO (2001), durante o século XVIII, houve várias tentativas de incorporação em áreas urbanas, de forma segregada e controlada, de populações marginalizadas, como a política de integração indígena prevista para Porto Seguro, em que se anexou à cidade uma aldeia indígena, por meio de um arruamento geométrico.

O mesmo autor mencionou, ainda, a incorporação de Vila Maria do Paraguay, habitada por índios e portugueses; Cáceres, no Mato Grosso; a construção da Aldeia de São Miguel, em Rondônia, de forma semelhante a acampamentos militares, objetivando fixar índios antes próximos à fronteira; e finalmente o quilombo Buraco do Tatu, na Bahia, que também possuía arruamentos regulares.
Durante três séculos esta foi a relação estabelecida entre urbano e rural. No início do século XIX, com a mudança da família real portuguesa para a cidade do Rio de Janeiro, paulatinamente a relação entre cidadãos e a terra urbana começou a mudar.

Após a proclamação da independência foi promulgada a Lei de Terras, Lei $N . .601$, de 18 de setembro de 1850. Essa lei dispunha sobre as terras devolutas do Império e as terras possuídas a título de sesmaria, sem preenchimento das condições legais, bem como por simples título de posse mansa e pacífica. O diploma determinou que as primeiras fossem medidas e demarcadas e então vendidas a particulares ou para o estabelecimento de colônias de estrangeiros.

A partir de então, a única forma de posse legal da terra passou a ser a compra devidamente registrada. "Foram duas as conseqüências: o reconhecimento do acesso a terra se desvinculou da condição de efetiva ocupação e esta adquiriu 'status' de mercadoria" (ROLNIK, 1997: 23). Desse momento em diante, os que se apossassem de terras devolutas ou alheias estariam sujeitos ao despejo sem pagamento de indenizações por benfeitorias, prisão de dois a seis meses e multa de $100 \$ 000$ (MARTINS, 1979). Não por acaso, essa mesma lei tratava da ocupação da terra por meio da fixação de trabalhadores europeus, livres, para a lavoura.

Essas transformações na economia mundial foram fruto da revolução industrial e do florescimento de um novo capitalismo, principalmente via Grã-Bretanha, que provocaram a decadência do antigo regime escravagista. 
Em 1849 e 1850 a armada britânica ocupou vários portos brasileiros, para pressionar o país a libertar os escravos. Como resultado dessas pressões, pouco a pouco os proprietários das lavouras de café vão substituindo os escravos por imigrantes europeus livres. Como assinala MARTINS (1979), "a terra no Brasil é livre quando o trabalho é escravo, no momento em que se implanta o trabalho livre, ela passa a ser cativa".

Enfim, em 1864 foi promulgada a Lei de Registros, Lei $\mathrm{N} .{ }^{\circ}$ 1237, pela qual as hipotecas não teriam efeito se não registradas. Essa lei confere maior controle dos negócios imobiliários, pelo Império. Portanto, ao longo do século XIX, a terra, gradualmente, substituiu o escravo na composição da riqueza da "aristocracia". Se antes o principal capital do fazendeiro era o escravo, então, passou a ser a terra.

Entender essas transformações é fundamental para perceber o câmbio que sofreu o processo de construção de nossas cidades. Como observou ROLNIK (1997), a separação entre propriedade e efetiva ocupação, provocou o aparecimento dos loteamentos ou arruamentos. Os limites dos terrenos passaram a ser importantes quando se tratava de a eles se atribuir um preço e de registrá-los. Daí surgiram os primeiros planos de arruamento municipais, com o estabelecimento dos alinhamentos, como ocorreu em São Paulo em 1886. Quase ao mesmo tempo surgiu a necessidade de serem estabelecidos critérios mais rígidos para as construções, sobretudo em função das questões de ordem sanitária, conforme já abordamos no início do Capítulo 3.

Já no início do século $X X$, com a queda do preço do café no mercado internacional, os fazendeiros passaram a diversificar seus investimentos em imóveis urbanos. Neste momento nasceu a crença de que investir em imóveis seria o único negócio verdadeiramente seguro. Crença que atravessou imutável várias alterações no panorama econômico ao longo do século $X X$.

Assim, todas as definições da legislação urbanística passaram a interferir diretamente no valor da terra, indo além das implicações técnicas e estéticas (ROLNIK, 1997: 25). Este é um dos pontos centrais da presente pesquisa, que será aprofundado no Capítulo 5.

Desta forma, como aponta ROLNIK (1997), surgiu a preocupação com a valorização dos imóveis. Fatores como a localização e a vizinhança adquiriram grande importância. Em função da representação democrática nas câmaras municipais ser frágil na Primeira República, uma vez que só a elite de fazendeiros e investidores imobiliários estava apta a votar, a primeira preocupação das legislações municipais, além de redesenhar as ruas centrais, foi eliminar certas formas de ocupação nestas áreas. Como já vimos, no Capítulo 3, essa preocupação correpondente ao "higienismo" foi o alvorecer do uso da legislação urbanística em benefício da segregação espacial nas metrópoles brasileiras.

Em Santos, como em São Paulo, proibiu-se a construção de cortiços nas áreas ocupadas pelas elites. Procurou-se, assim, demarcar territórios de excelência sanitária. Por exemplo, o Código de Posturas de Santos, elaborado em 1994, e promulgado em 1997, vedou a construção de edificações com "tapumes de zinco, madeira, cerca de 
arame ou espinhos, nas frentes das ruas ou praças, dentro do perímetro da cidade(...)" (grifo do autor) ${ }^{65}$.

$\mathrm{Na}$ virada do século, a imensa maioria dos trabalhadores imigrantes ou escravos recém libertados não possuía outra alternativa de moradia, que não a das construções coletivas em velhos casarões subdivididos ou em "puxados", nos quintais. A legislação procurou, assim, reprimir essa alternativa de moradia. Como assinala (ROLNIK, 1997: 37), "esse tipo de intervenção no território popular complementava 0 projeto urbanístico municipal de construção de uma nova imagem pública para a cidade, aquela de um cenário limpo e ordenado que correspondia à respeitabilidade burguesa com a qual a elite do café se identificava".

Com a evolução das pesquisas científicas, ao final do século XIX, especialmente na área de microbiologia, e com a grande preocupação com as epidemias que dizimaram milhares de vidas, a obsessão com fatores como insolação e ventilação das construções foram explicitadas nos códigos de obras e posturas municipais. Estas questões serão abordadas neste trabalho, ao ser analisada a legislação do século XIX e início do XX. Sintomaticamente essas restrições edilícias foram mais marcantes nos territórios das classes mais abastadas.

\footnotetext{
${ }^{65}$ É fundamental ressaltar a questão da demarcação do perímetro da cidade, a qual passou a ser de extrema importância como instrumento de segregação, a partir de então. Nota-se, também, que no final do século XIX e princípio do XX a forma mais comum de vedação das propriedades ocupadas pela baixa renda era a cerca de madeira $e$ zinco, edificado em terrenos vagos, ou em quintais de edificações já existentes dentro do núcleo urbano.
}

Embora tema das legislações municipais, principalmente no Rio e em São Paulo, o urbanismo sanitarista foi tratado de forma mais profunda pelo governo da Província de São Paulo, com a criação do Serviço Sanitário em 1890 e a promulgação do Código Sanitário, em 1894. Era grande a preocupação do governo com as repercussões das freqüentes epidemias, em Santos e São Paulo, que provocaram conseqüente decréscimo na imigração européia. Era fundamental manter uma política de subsídio ao fornecimento constante de mão de obra barata às lavouras cafeeiras.

Outra transformação foi advinda dos investimentos municipais em infra-estrutura, unicamente nas áreas centrais, e pela necessidade de tirar da terra seu rendimento máximo. Dessa forma, logo se estabeleceu uma polêmica entre aqueles que defendiam o sanitarismo radical e os que, atentos ao potencial da terra nessas áreas, defendiam a verticalização das construções. No debate contrapôs-se a experiência do urbanismo americano, particularmente do Model Housing Law, do novo urbanismo alemão, a partir do "zoning" de Frankfurt, ao paradigma da cidade medicalizada que a tradição do higienismo francês exportou para o mundo (ROLNIK, 1997: 44).

A nova tese, segundo ROLNIK (1997) era de que a redução do pé-direito e a construção de mais pisos diminuiriam o custo das construções, beneficiando o trabalhador, mas que o controle do número de pessoas morando juntas não se dava através da legislação urbanística, mas deveria ser uma preocupação das autoridades sanitárias. De fato as teses não eram inteiramente opostas. Dessa maneira, o centro das grandes cidades foi pouco a pouco sendo dominado pelos arranha-céus, e um processo vertiginoso 
de reconstrução desses espaços destruiu grande parte da memória edificada das cidades coloniais brasileiras que se transformavam em metrópoles, no começo do século, como o caso do centro de Santos, que guarda raros vestígios do período colonial.

Ao mesmo tempo, o conceito de zoneamento como forma de segregar usos e garantir a máxima rentabilidade da terra foi paulatinamente sendo implantado. Leis foram aprovadas, criando bairros exclusivamente residenciais com grandes exigências urbanísticas, como recuos e limites à altura das edificações. Essas medidas, "cuja chave da eficácia em demarcar um território social, reside no preço, possibilitaram a implantação de loteamentos, com lotes de grandes dimensões e, assim, acessíveis a poucos" ROLNIK (1997: 47). Estas a autora denominou "muralhas invisíveis".

Desenhou-se, a partir de então, como destacou ROLNIK (1997: 47), "o fundamento de uma geografia social da cidade, da qual não conseguimos escapar até então". Outra importante questão era que os investimentos públicos em infra-estrutura estavam comumente associados aos grandes empreendimentos imobiliários, posto que as câmaras eram influenciadas por empresários do ramo ou grandes donos de terras $e$ isso incentivou o desenvolvimento da urbanização periférica tão bem analisada por BONDUKI (1998).

ROLNIK (1997) associou essa dinâmica ao surgimento de um imenso território marginal em nossas metrópoles, o qual denominou "cidade informal", devido ao fato de não haver grande interesse na adoção de parâmetros para edificar e parcelar o solo, equivalente ao dispensado aos territórios ocupados pelas elites, como será visto a seguir no caso da RMBS.

Ressalta-se que nessa "cidade informal", quando foram implantados serviços básicos como água, luz e esgoto, isto se deu a um custo altíssimo para a sociedade, tais as distâncias dos bairros residenciais operários aos centros urbanos provedores de emprego, como no caso da área continental de São Vicente, como se pôde ver ao ser analisado o caso específico deste município, no item 4.2. Por conseqüência viu-se agravar ao longo do século $X X$ problemas como o do transporte público e saneamento, que se devem, em grande medida, a esse fenômeno.

Entretanto, nesse cenário de crescente segregação social do início do século XX é promulgado, em 1916, o Código Civil, que trouxe alguns avanços, como a nova modalidade de usucapião - pois antes era possível até mesmo o usucapião em terras públicas. Esse código excluiu do rol das terras públicas, não sujeitas ao usucapião, as terras devolutas. O maior avanço se deu ao definir os diferentes tipos de posse, objetivamente como justa ou injusta, subjetivamente como de boa ou má fé e, segundo a idade, como nova - menos de um ano e um dia - ou velha - mais de um ano e um dia.

A partir do Código Civil, quando a posse fosse exercida por multidão, sem limites determinados que distingüisse um possuidor do outro, como ocorre nas favelas, passou-se a ter a "composse" ou "posse múltipla". Outro avanço introduzido por este Código é que se a posse fosse exercida sobre espaço pertencente a autarquia ou entidade paraestatal, cujos fins estatutários fosse os de facilitar a aquisição de moradia por pessoas de baixa renda, a 
regularização fundiária poderia ocorrer por meio de Concessão do Direito Real de Uso.

Após a Primeira Guerra Mundial, um surto inflacionário abateu-se sobre o mercado imobiliário baseado nas importações de materiais de construção. Tal surto provocou um crescimento incontrolável nos valores dos aluguéis, gerando grande descontentamento nas classes operárias. Somado a esse fator, as concessões de serviços públicos nas mãos de grandes empresas estrangeiras não permitiam nenhum controle das altas tarifas, nem tão pouco era do interesse destas investir em ampliação de suas redes em loteamentos populares. Isto ocorreu porque que elas estavam também associadas aos grandes empreendimentos imobiliários das cidades, como ocorreu em Santos, com a Companhia City of Santos Improvements.

O quadro de inflação e escassez do pós-guerra foi acompanhado por freqüentes passeatas e protestos nas ruas. Seguiram-se distúrbios e greves gerais. A resposta do governo foi a repressão e o aumento das fraudes eleitorais. Washington Luís, quando prefeito de São Paulo, declarou: "A questão social é um caso de polícia". Não tardou a surgirem cisões na base governista e o aparecimento de uma nova forma de fazer política, a populista. Essa crise produziu as revoltas e revoluções de 1924 a 1932, que culminaram com a implantação do Estado Novo e o longo período de domínio da política nacional pela personalidade de Getúlio Vargas.

No cenário internacional a evolução do urbanismo foi marcada pela realização dos Congressos Internacionais de Arquitetura Moderna, os CIAM. A primeira fase dos CIAM, entre 1928 e 1933, como lembrou MARICATO (2000: 127), "foi mais comprometida com as questões sociais, contribuindo para a solução dos 'problemas urbanos' nos países capitalistas centrais, em especial o problema da habitação". A palavra de ordem era diminuir custos e garantir um padrão mínimo de qualidade, visando resolver o problema de moradia da classe trabalhadora. Os projetos de unidades habitacionais criados a partir dessa nova ordem revolucionaram a arquitetura e o urbanismo. Eliminaram-se ornamentos das fachadas, priorizaram-se tipologias em blocos e a hierarquia da circulação. Buscouse reduzir a planta da moradia ao mínimo, sem prejuízo da qualidade.

Foi o alvorecer do movimento modernista, que resultou no $2^{\circ} \mathrm{CIAM}$ com o lema "Habitação para o mínimo nível de vida", sob a liderança do arquiteto Ernest May. A planta da unidade habitacional foi definitivamente racionalizada, "considerando a mudança do papel da mulher na sociedade, os novos produtos industriais domésticos (aparelhos e alimentos), as novas instalações prediais" (MARICATO, 2000: 127). Essa mudança, como será observado na análise que faremos em seguida, refletiu-se na legislação edilícia, alterando o padrão mínimo de exigência, seja pela redução de dimensões, seja pela nova organização dos cômodos e pé-direito.

Segundo MARICATO (2000: 128), "A partir daí, o movimento fez uma inflexão, ganhando peso uma orientação mais formalista e mais engajada ao processo de acumulação capitalista". Nessa segunda fase, entre os anos 1933 e 1947, foi formulada a Carta de Atenas e segundo a autora consolidou-se a "visão essencialmente funcionalista, sob a liderança de Le Corbusier". 
A cerca desse período, podemos ler em FARAH (1998: 33): "Diferentemente do que ocorria na Europa, a nova mentalidade urbanística, no Brasil, não era devidamente acompanhada por uma política clara de produção de habitações de interesse social, o que abria uma grande lacuna ao longo dos anos, para o surgimento de 'soluções espontâneas'. Ainda que o Estado esboçasse periodicamente ações no sentido de resolver o problema habitacional, suas iniciativas, nesse sentido, sempre estiveram num patamar bastante aquém das reais necessidades".

No entanto, a partir do anos entre as guerras mundiais, no Brasil a velha ordem foi paulatinamente sendo superada, sendo aberto o caminho para mudanças na relação do trabalhador com o governo, marcadas pelo populismo que caracterizou o período de Vargas. Ao final dessa fase ocorreu uma grande alteração nos padrões de urbanização, em função do surgimento e desenvolvimento da indústria automobilística, que redesenhou as cidades e alterou as relações de tempo e espaço dentro destas. Estava inaugurada a era dos grandes projetos viários, sem, contudo abandonar-se as diretrizes de embelezamento da cidade.

Nessa época os planos de embelezamento ainda permaneceram como paradigma do planejamento no Brasil. O Plano Agache, para o Rio de Janeiro, possivelmente foi precursor dos planos elaborados após a década de 1950, em que prevaleceram os "planos globais". Este plano propunha uma série de intervenções para o Rio, a capital federal, nas áreas de saneamento, drenagem e habitação. Como ensinou VILLAÇA, foi no Plano Agache, elaborado na França, a primeira vez em que se mencionou o termo "plano diretor" no Brasil, aliás, plan directeur - embora os urbanistas franceses preferissem a expressão plan d'amenagement.

Após a Segunda Guerra Mundial, com o incremento da industrialização no sudeste brasileiro, estradas foram abertas, as comunicações aperfeiçoadas, sendo implantada a indústria siderúrgica e petroquímica nacional. Nesse período aprofundou-se definitivamente a transformação do Brasil em um país predominantemente urbano, com enorme acréscimo nas migrações, sobretudo no eixo nordestesudeste. A explosão populacional das grandes metrópoles, principalmente de São Paulo e Rio de Janeiro, fez aumentar significativamente a pressão social pela posse da terra.

Nesse cenário, em 1946 foi sancionado o Decreto-Lei $\mathrm{N}^{\circ}$ 9.760 , que dispôs sobre os bens imóveis da União. Essa matéria estabelecia critérios para locação dos próprios da União, para cessão, ocupação e aforamento - este último fundamental na questão fundiária dos terrenos de marinha no litoral e da Baixada Santista, em especial. Esse mesmo diploma tratava da legitimação da posse das terras devolutas, que permanecia em vigor. Posteriormente, em 1967, o Decreto-Lei N²71 disporia sobre a competência das pessoas jurídicas de direito público interessadas na concessão de uso de imóveis urbanos, como forma de promoção da regularização fundiária.

No entanto, a política populista não foi capaz de dar conta das necessidades sociais advindas desse novo ciclo econômico, que denominamos Período Desenvolvimentista. A fase foi marcada pelo crescimento desordenado das cidades, ainda mais intensamente, devido principalmente à ausência de políticas públicas que fornecessem alternativas 
habitacionais à massa popular que crescentemente ocupava a periferia e os centros urbanos degradados.

Para a carência de moradias e serviços públicos das populações de baixa renda das grandes metrópoles essa política não apresentou soluções satisfatórias. Esse foi o caldo de cultura que contribuiu para a superação do populismo de Vargas e com o período conturbado que culminou com o golpe de 1964, que derrubou o governo de João Goulart, e instaurou a ditadura militar no país, eliminando direitos básicos dos cidadãos.

A política do desenvolvimento a qualquer custo, esboçada com relativo sucesso nos anos J.K., no final da década de 1950, foi retomada com mais força nos governos militares, que aplicaram rigorosamente a receita conservadora do "fazer crescer o bolo antes de dividi-lo". Essa política, apoiada numa estratégia de propaganda ufanista e "patriótica", nos primeiros anos, pouco contribuiu com mudanças concretas nas relações que permitiam a manutenção das desigualdades nos territórios urbanos. Ao contrário, as aprofundaram.

No caso de Santos, ainda em 1951, foi aprovado o Plano Regulador de Expansão da Cidade, cuja elaboração foi coordenada pelo urbanista Prestes Maia. A cidade sofreu novo redesenho, com o alargamento e abertura de novas vias, iniciando-se o processo, que dura até hoje, de substituição da arquitetura eclética produzida pelo urbanismo sanitarista e pelo ciclo do café.

Nessa época consolidou-se no planejamento a elaboração de diagnósticos urbanos altamente detalhados, preconizando soluções "cientificas" para o crescimento das cidades, levando às últimas conseqüências o funcionalismo e o zoneamento de usos. Durante as décadas de 60 e 70, surgiu com grande força nas metrópoles brasileiras 0 instituto dos Planos Diretores. Como demonstrou VILLAÇA (1998), dezenas deles foram produzidos e a grande maioria não resultou em efeitos práticos, pois não era passível de aplicabilidade devido à sua elaboração desvinculada do processo político.

Esses planos procuravam apontar vetores de crescimento das cidades, alternativas para a adequação de densidades habitacionais às infra-estruturas e superestruturas urbanas, como forma de resolver os conflitos urbanos e gerar desenvolvimento. Mais raramente, como no caso de Santos, abordavam os aspectos de uso e ocupação do solo, com grande ênfase à aplicação do zoneamento.

Especificamente em Santos, com a sanção da Lei $N^{\circ} 3.529$, de 1968 - Plano Diretor Físico do Município, reforçou-se em definitivo a demarcação dos espaços formais e não-formais na cidade, acentuando suas diferenças e condenando a população de baixa renda a ficar à margem dos investimentos públicos. Isso se deu porque o Plano vinha atrelado à regulamentação de uso do solo.

No entanto, a grande maioria dos planos diretores, apoiada numa vasta gama de diagnósticos e prognósticos para as metrópoles, acabou por não ser aplicada, limitando-se a colocar o debate do futuro das cidades na agenda técnica da época.

Conceitos hoje generalizados como o equilíbrio do ambiente urbano e as questões sociais das cidades foram pouco ou quase nada considerados pelos planos diretores desse 
período, predominantemente focalizados na questão das acessibilidades e controle de densidades habitacionais.

Sobretudo esses planos não dispunham de propostas eficazes para equacionar a questão da moradia e do emprego e renda para as classes trabalhadoras. Pelo contrário, eles foram incapazes de impedir a desordenada ocupação das áreas periféricas - nas décadas de 60 a 80 pela população de baixa renda, dobrando ou triplicando as dimensões da cidade informal. Em Santos, como será visto, essa lógica perversa acabou por ser reforçada pelo plano de 1968.

As soluções adotadas para suprir o déficit habitacional nesse período, como durante o período anterior, passavam invariavelmente pela implantação de imensos conjuntos habitacionais, geralmente em localizações distantes do centro que, por sua vez, acabaram por constituir-se num território à parte na cidade, reproduzindo a lógica da segregação espacial, fenômeno profundamente abordado em BONDUKI (1998).

Em 1973 é promulgada a atual Lei de Registros Públicos, Lei $\mathrm{N}$. .6 .015 , alterada pela Lei 9.785 , de 29 de janeiro de $1999^{66}$, que tratava do registro dos imóveis nos Cartórios de

${ }^{66}$ A Lei $N^{\circ} 9.785$, de 29 de janeiro de 1999, alterou o Decreto-lei $N^{\circ}$ 3.365, de 21 de junho de 1941 - desapropriação por utilidade pública - e as leis $\mathrm{N}^{\circ} 6.015$, de 31 de dezembro de 1973 - registros públicos - e $\mathrm{N}^{\circ}$ 6.766 , de 19 de dezembro de 1979 - parcelamento do solo urbano - e visava atingir quatro objetivos básicos: universalização do acesso à moradia, ampliação do estoque de moradias e melhoria das habitações existentes, regularização dos assentamentos e promoção do acesso à terra urbana, e modernização do setor habitacional com o aprimoramento da legislação e da capacitação dos agentes e da qualidade de produção.
Registros Imobiliários. Em sua versão original, essa lei constituiu-se num dos mais sérios obstáculos à regularização fundiária, pelo alto grau de dificuldade criado às transmissões imobiliárias em áreas de interesse social. Isso passou a ocorrer, pois quando o poder público decidia pela regularização fundiária de uma determinada área, a lei determinava que este fosse primeiramente à circunscrição imobiliária verificar se havia ou não registro anterior de propriedade da mesma, para que pudesse negociar sua desapropriação. O que ocorria com grande freqüência, é que se encontravam incongruências entre o livro onde estavam registrados e descritos os imóveis segundo seus limites e localização, e o livro onde estes estavam registrados segundo seus proprietários.

Até hoje é comum, na maioria dos municípios, que os dados constantes dos registros não estejam de acordo com o cadastro da prefeitura. Em todos esses casos, o processo de registro, que visava por fim a pendências judiciais, passou a dar origem a outras pendências. Nessas situações, mesmo assistidas pelo poder público, as populações beneficiárias dos processos de regularização fundiária foram tomadas pelo desânimo, devido a morosidade dos encaminhamentos jurídicos necessários a sanar essas incongruências.

Nesse aspecto a alteração da lei, em 1999, trouxe alguns avanços, que poderão vir a tornar menos burocratizado o trâmite. Entre eles há o dispositivo do parágrafo $4^{\circ}$, do artigo 18, que dispensou o título de propriedade da terra, "quando se tratar de parcelamento popular, destinado às classes de menor renda, em imóvel declarado de utilidade pública, com processo de desapropriação judicial em curso e imissão provisória na posse, desde que promovido pela 
União, Estados, Distrito Federal, Municípios ou suas entidades delegadas, autorizadas por lei a implantar projetos de habitação".

Antes, porém, em 19 de dezembro de 1979, houve a promulgação da Lei $\mathrm{N}^{\circ} 6.766$, que disciplinou 0 parcelamento do solo urbano. O dispositivo anterior sobre a matéria, Decreto-Lei $N^{\circ} 58$, de 1937, procurou sanar imperfeições constantes no código civil, sobre o tema da promessa de compra e venda de imóveis loteados, o qual deixou sem amparo milhares de compradores de lotes. Em 1949, a Lei $N^{\circ} 649$ estendeu os efeitos daquele decreto aos imóveis não-loteados, aumentando as garantias aos compradores.

A Lei $\mathrm{N}^{\circ}$ 6.766, também conhecida como Lei Lehmann, estabeleceu disposições que tentaram reunir a experiência legal, jurisprudencial e doutrinária acumuladas até então, sobre os efeitos de um mercado no espaço urbano. Hoje, no rastro dessa lei, estados e municípios têm aproveitado a competência que ela lhes conferiu para tentar disciplinar o parcelamento do solo. Esse diploma, que também foi aperfeiçoado em $1999^{67}$, estabeleceu sanções aos loteamentos irregulares e aos clandestinos, especialmente para os loteadores que não cumprissem as suas exigências, sobretudo no tocante à implantação de infraestrutura e reserva de áreas destinadas às praças, áreas verdes, sistema viário e equipamentos públicos.

No entanto, como ressalta ROLNIK (1997), "o artigo 38, que obriga 0 adquirente a suspender os pagamentos das prestações devidas, no caso de constatada alguma irregularidade ou clandestinidade, com raríssimas exceções, tem permanecido letra morta". De modo geral, parece haver um pacto velado pela impunidade, entre poder público e judiciário, pois os parcelamentos irregulares são hoje, a exemplo do que ocorre na RMBS e, principalmente, na RMSP, grande parte dos territórios urbanos e uma das alternativas disponíveis para 0 auto-empreendimento habitacional das classes de baixa renda. De fato, são raras as punições a infratores dessa lei. Fica claro o regime de consentimento à transgressão, que transforma e degrada brutalmente o ambiente natural das metrópoles.

Após a restauração do regime democrático no país, em 1988 foi promulgada a nova Constituição Federal, e a questão da terra urbana experimentou alguns avanços importantes. Nos artigos 29 e 30 da Constituição alguns incisos deram poderes ao município para intervir no território local. O artigo 29 mencionou a "cooperação das associações representativas no planejamento municipal" e abriu à população a possibilidade de "elaborar projetos de lei de interesse específico do município, da cidade ou dos bairros". O artigo 30 outorgou aos municípios o poder de "promover, no que couber, adequado ordenamento territorial, mediante planejamento e controle do uso, do parcelamento e da ocupação do solo urbano".

No entanto, o espírito do planejamento modernista ainda permaneceu na nova Constituição. O capítulo "Da Política Urbana" estabeleceu, no artigo 182, a necessidade da elaboração do plano diretor para municípios com população superior a 50 mil habitantes, fato que generalizou no Brasil, esse paradigma do planejamento, já bastante questionado à época.

\footnotetext{
${ }^{67}$ Pela Lei $\mathrm{N}^{\circ} 9.785$, de 29 de janeiro de 1999.
} 
Mas é nesse mesmo artigo que a Constituição apresentou os maiores avanços para a questão urbana, pois nele foram previstas as condições de cumprimento da chamada "função social da propriedade urbana", e das desapropriações, cabendo ao município poder de polícia quanto à utilização inadequada do território por particulares. E nos artigos 182 e 156 que se definiu o instituto do Imposto sobre a Propriedade Predial e Territorial Urbana IPTU - progressivo ${ }^{68}$, regulamentado pela Lei Federal $\mathrm{N}^{\circ}$ 10.257, de 10 de julho de 2001 - Estatuto da Cidade. Esse instrumento, se aplicado efetivamente, poderá figurar como poderoso indutor de redistribuição de investimentos públicos no território da cidade, na medida em que permitir tratar diferenciadamente, do ponto de vista fiscal, os territórios das elites e os territórios da baixa renda.

No artigo 183 foi prevista a usucapião pró-moradia e a concessão real de uso, como formas de regularização fundiária. De fato, o instituto da usucapião é muito antigo, como ensinou SAULE Jr. (1999: 211-217). Mas a Constituição de 1988 aperfeiçoou-o, prevendo o reconhecimento dessa forma de aquisição da propriedade urbana, desde que o usucapiente estivesse na posse "pelo prazo de cinco anos, segundo construção jurisprudencial", e não fosse proprietário de qualquer outro imóvel urbano ou rural. Há ainda, a exigência de moradia efetiva, de uso exclusivamente residencial e de que o lote não excedesse $250 \mathrm{~m}^{2}$, nem fosse de domínio público, dispositivos reafirmados no Estatuto da Cidade.

\footnotetext{
${ }^{68}$ A Emenda Constitucional $N^{\circ} 91$, de setembro de 2000, regulamenta a progressividade do IPTU, quanto à localização e quanto ao uso dos imóveis, possibilitando a adoção de alíquotas diferenciadas, mas não regulamenta a chamada "progressividade no tempo", sobre os imóveis urbanos ociosos ou subutilizados.
}

Ainda segundo SAULE Jr. (1999: 194), "o Direito Real de Uso deve ser utilizado para atender a função social da propriedade pública, garantindo-a àquele que possuir como sua área urbana pública de até $250 \mathrm{~m}^{2}$ e atender aos mesmos requisitos constitucionais de exercício de posse exigidos para o usucapião".

É importante frisar que o projeto de lei do Estatuto da Cidade vinha sendo discutido e modificado desde a década de 1980, em tramitação bastante lenta no Congresso Nacional, com sua pautação sistematicamente procrastinada, fato que não é difícil de entender, uma vez que, como se sabe, aquela Casa de leis tem uma composição majoritariamente de orientação patrimonialista.

A Lei $N^{\circ}$ 9.785, sancionada em 1999, visou facilitar os critérios para aprovação de parcelamentos e para tal fim, entre outras coisas, limitou as exigências de implantação de infra-estrutura a um mínimo aceitável pelos padrões atuais. Com igual objetivo, essa lei admitiu "a cessão da posse em que estiverem provisoriamente imitidas a União, Estados, Distrito Federal, Municípios e suas entidades delegadas, o que poderá ocorrer por instrumento particular, ao qual se atribui, para todos os fins de direito, caráter de escritura pública(...)". Pode-se supor que esses e outros dispositivos trazidos pela nova legislação poderão trazer avanços na regularização de assentamentos subnormais, porém, ainda é cedo para avaliar, em maior profundidade a eficácia da Lei $N^{\circ} 9.785$, em função de seu pouco tempo de vigência.

Como destacou ROLNIK (1997: 181), comentando os efeitos da aplicação da legislação urbanística, na década de 90, próximo ao fim do século, "a organização espacial das grandes cidades brasileiras está regulada por uma ordem 
jurídico-urbanística fortemente enraizada nos princípios formulados no início do século". Essa ordem, além de não evitar sua formação, "possibilitou a contraposição de um espaço contido na minuciosa observância dos ditames urbanísticos e outro, muitas vezes maior, situado numa zona entre o legal e o ilegal. Porém esta contraposição não é total. A ordem jurídica ou estatal nunca está totalmente ausente deste último e a valorização das regiões ultraregulamentadas provoca uma série de transgressões nos imóveis nestas localizados".

E ainda, ROLNIK (1997: 182) apontou uma questão central, que será abordada a seguir, no caso da RMBS: "A partir de 1980, notadamente, governos estaduais e municipais acabaram por estender redes de água e de luz aos assentamentos subnormais mais organizados, adotando política tarifária diferenciada". É importante notar que mesmo "os proprietários de barracos nas favelas constituem um mercado imobiliário inserido na hierarquia dos preços praticados na cidade". E, também, em ROLNIK (1997: 182),

"Permanece, entretanto, o sentimento de repulsa a este 'desvio' de direito que é o habitar em favelas e cortiços, que imediatamente associa seus moradores a vida do crime. Neste aspecto, a ordem jurídico-urbanística se encarrega de explicitar esta rejeição, demarcando o território, mas não é capaz de eliminar este espaço. Nos mapas urbanísticos, estes espaços não são geralmente desenhados, como se uma parte da cidade fora eliminada. São dezenas de hectares que não se sabe se fazem ou não parte da cidade, mas acabam sendo tomados como provisórios. Esta posição acaba funcionando muitas vezes como justificativa para 0 não investimento".
Nesse aspecto, em decorrência dos avanços possibilitados pela Constituição Federal de 1988, algumas administrações municipais estabeleceram instrumentos legais para enfrentamento da segregação espacial, procurando inserir no "mapa da cidade" seus territórios marginais. Associados a parcos programas de política de financiamento federal ou estadual, estes instrumentos puderam permitir novas experiências de inclusão social, ainda que, como será visto adiante, não sejam capazes de resolver questões de fundo ligadas à macro-economia. 


\subsection{A evolução da regulação urbanística em Santos}

Neste item será aprofundada a analise da evolução da legislação urbanística dos municípios centrais da RMBS, desde o Período do Café ao final do Período Desenvolvimentista, em especial no que concerne à questão da exclusão espacial da população de baixa renda. Para tal fim procurar-se-á destacar os aspectos que provocaram direta ou indiretamente a elevação desse valor, e demais dispositivos segregacionistas introduzidos pela legislação.

Metodologicamente, será estudada em maior profundidade a legislação da cidade de Santos, que pelo contexto histórico de sua importância é a maior e mais completa dentre os municípios da RMBS. Para os demais municípios a serem abordados nesta etapa da pesquisa o foco estará voltado para as leis mais importantes, que significaram alterações mais profundas de padrão urbanístico e edilício para as respectivas cidades.

Vale destacar, ainda, que à exceção de São Vicente, os demais municípios centrais surgiram do fracionamento do território santista e em seus períodos iniciais de autonomia política era utilizada a legislação urbanística de Santos. E, dessa forma, a sua aplicabilidade estava associada mais diretamente ao processo de urbanização dessa cidade.

É importante ressaltar, também, que nos primórdios da regulação do espaço urbano, os códigos continham, sem fazer muita distinção, dispositivos de regulamentação das construções particulares, de posturas e de intervenção no espaço público. O primeiro tipo de regulação denomina-se legislação edilícia e era a mais preponderante até o início do processo de adensamento da cidade de Santos, na segunda metade do século XIX.

Da mesma forma, os dispositivos que regulavam o comportamento do cidadão e de suas atividades exercidas no espaço público, os quais denominam-se posturas municipais, só vieram a ser tratados em lei de forma separada na década de 60 do século XX. O foco principal desta etapa do trabalho, a regulação urbanística propriamente dita, era tratada em conjunto com a edilícia até esse mesmo período, quando finalmente desvincularam-se os códigos de edificações das leis de zoneamento e parcelamento do solo.

Santos, conforme revelou esta pesquisa, é a cidade da RMBS que possui a legislação voltada para a produção do espaço urbano, mais completa e mais antiga. Por certo isto se deve ao fato da cidade ter adquirido, mais que as outras, grande importância estratégica durante o ciclo do café. Além disso, municípios como Cubatão, Guarujá e São Vicente, não passavam de pequenos núcleos até o primeiro quartel do século $X X$.

Para melhor aprofundar a análise, separar-se-á o estudo dessa legislação em três períodos, o inicial, com princípio em meados do século XIX, quando é promulgado o primeiro Código de Posturas de Santos e sua alteração na década de 1850 e posteriormente os dois períodos já identificados como Período do Café e Período Desenvolvimentista.

No primeiro período, promulga-se o primeiro código da cidade, recém-elevada a esta categoria. É o alvorecer da regulação autônoma do espaço em Santos. Um espaço, 
onde usos e costumes típicos da cidade colonial começam a transformar-se pelo surgimento de padrões burgueses.

No Período do Café a legislação era mais voltada para a produção da unidade, do edifício, e para o embelezamento da cidade, tentando transpor padrões de urbanidade europeus para a região.

No segundo, o Desenvolvimentista, cada vez mais conferiuse importância para a relação do edifício com a cidade, ampliando-se dispositivos de controle da produção do espaço urbano de maneira geral, adotando-se o zoneamento como paradigma de regulação urbana, levando o funcionalismo às últimas conseqüências. 


\subsubsection{A Legislação Urbanística em Santos em meados do século XIX}

Tendo sido uma vila de pouca relevância em todo período colonial, Santos foi elevada à categoria de cidade em 1839. Como lembrou NUNES (2001: 25), "A legislação que determinava os parâmetros construtivos nas cidades da época do império tinha origem no 'Regimento das Câmaras Municipais' uma Lei Imperial instituída por D. Pedro I, em $1^{\circ}$ de outubro de 1828".

Certamente a elevação à categoria de cidade ensejou a elaboração de suas primeiras normativas jurídicas próprias, consolidadas no projeto de lei do primeiro Código de Posturas Municipais, aprovado pela Câmara Municipal da Cidade de Santos e remetido à Assembléia Legislativa Provincial de São Paulo, onde foi aprovado e sancionado em 7 de março de 1847.

Sobre o Código apontou ANDRADE (1989: 67): "A leitura desse Código é reveladora em dois aspectos, pelo menos: os problemas da vida urbana e o objetivo pretendido pela Câmara Municipal, e, a cidade almejada. As exigências do código e as penalizações previstas para as infrações e desobediências, intimações e até açoites davam a medida da determinação da Câmara em atingir seu objetivo".

Esse novo código, um compêndio de 118 artigos divididos em 6 títulos, tratava de assuntos variados, desde o comportamento do cidadão até a construção de edifícios. Neste último aspecto, o código de 1847 era bastante sucinto. O Título $1^{\circ}$, com 12 artigos, que dispunha sobre "aberturas e alinhamentos de ruas e edificações", dava critérios bastante rígidos para a construção de edifícios, sem contudo demonstrar muita preocupação com sua inserção na incipiente malha urbana.

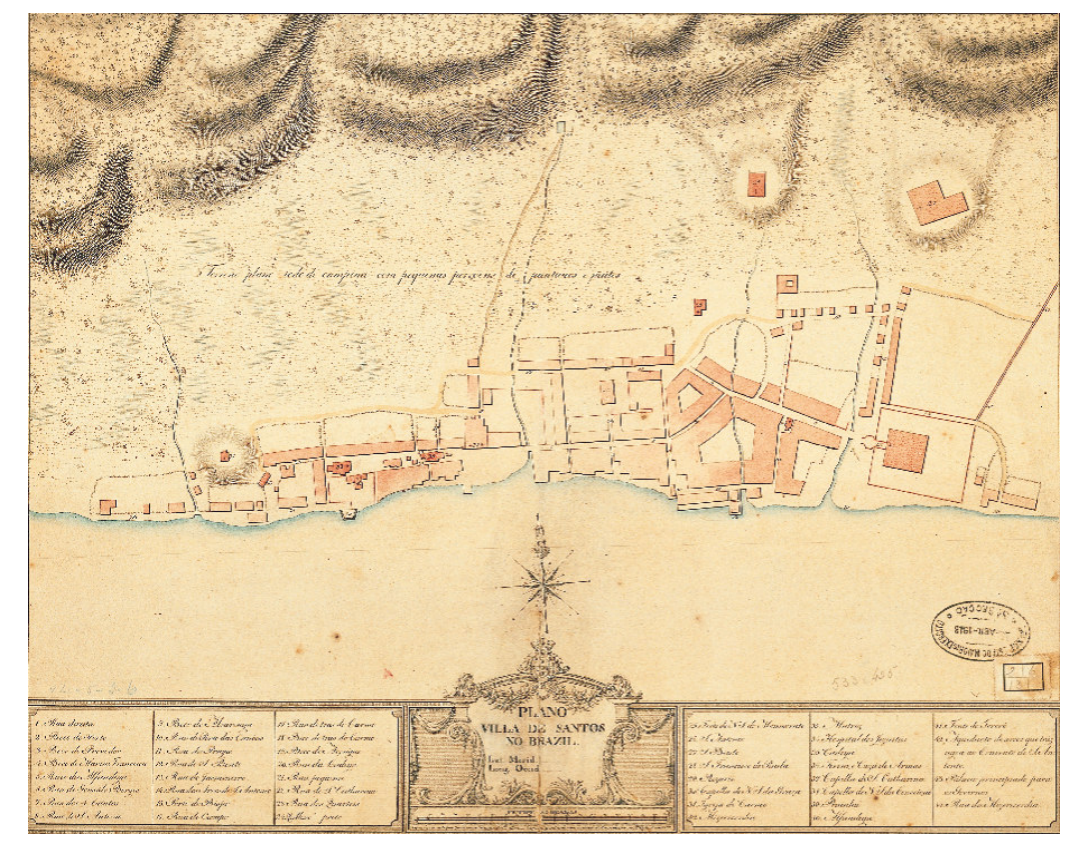

Figura 28 - Plano da Villa de Santos, copiado e ornado por José Correa Rangel, em 1798, a partir de levantamento executado em 1791. Provável autor: João da Costa Ferreira. Fonte: Nestor Goulart Reis Filho, reproduzido do Arquivo Histórico do Exército - CD ROM Imagens de vilas e cidades do Brasil Colonial, 2000.

$\mathrm{O}$ artigo $3^{\circ}$ estabeleceu que os edifícios térreos deveriam ter 18 palmos de altura, "nem mais, nem menos". Os sobrados deveriam ter o pavimento térreo com 18 palmos e o superior com 17 palmos. No caso de serem construídos mais pavimentos, coisa muito rara na época, a altura 
mínima deveria ser reduzida em 1 palmo a cada novo pavimento. Ressalta-se que não houve preocupação com o espaço interno das edificações, estando liberada sua subdivisão.

Entretanto, pode-se encontrar nos artigos $11^{\circ} \mathrm{e} 12^{\circ}$ embrião do que se tornaria, mais tarde, o processo de segregação espacial por meio da legislação urbanística. Pelo artigo $11^{\circ}$ ficou vedado recobrir de palha as edificações dentro da "povoação", ainda que não ficassem muito claros seus limites. No $12^{\circ}$ ficou estabelecida a obrigação de murar e caiar os terrenos das principais ruas da cidade, as quais foram nomeadas, uma a uma, definindo um perímetro correspondente ao núcleo original da mesma ${ }^{69}$.

Ficava clara, assim, a disposição de criar uma área onde alguns princípios e padrões de urbanidade fossem fixados, sem contudo preocupar-se com a forma de ocupação na imensa região externa a esse perímetro. Como se pode notar, pouco a pouco essa "zona de urbanidade" foi sendo ampliada, conforme a cidade se expandia, de acordo com critérios que privilegiaram o estabelecimento das classes de mais alta renda nas melhores localizações.

Essa forma de tratamento da área "não urbana" do município pode ser avaliada pelo artigo 107 que trata da questão do estabelecimento de curtumes. Diz o artigo: "Ninguém poderá estabelecer curtumes neste município, senão em lugares distantes pelo menos um quarto de légua das circunvizinhanças da cidade, ou das povoações (...)".

${ }^{69}$ Eram citadas as ruas Direita, Santo Antônio, da Praia, Meridional, Setentrional, Antonina, Delfina, largos do Chafariz e da Matriz e travessa da Alfândega Velha - logradouros da área entre os atuais bairros do Valongo e Paquetá.
O artigo $109^{\circ}$ vedou "dentro da cidade" o estabelecimento de fábricas em "que se trabalhe com ingredientes que exalam vapores que possam alterar ou corromper a salubridade da atmosfera". O mesmo artigo estabeleceu que essas fábricas poderiam ser localizadas, "sob licença" da Câmara, "fora das povoações, em lugares por ela (Câmara) designados". Ou seja, ainda que de forma rudimentar e subjetiva, instituía-se uma segregação de usos baseada no impacto que determinadas atividades exerciam sobre a vida da burguesia nascente.

Posteriormente o código de 1847 sofreu pequenas alterações, por meio de projeto aprovado pela Câmara Municipal, em 31 de dezembro de 1852, e sancionado pela Assembléia Provincial em 24 de abril de 1857. A nova organização do código consistiu em redistribuir os artigos em 11 títulos, ampliando seu número para 119. No que concerne às questões urbanísticas, nenhuma novidade de monta foi introduzida, exceto que os mesmos padrões edilícios foram estabelecidos em uma tabela anexa à lei, denominada "Padrão para edifícios que se construírem no Município de Santos". Outra novidade, contida no artigo $1^{\circ}$, estabelecia que além das edificações em Santos, as que se construíssem na "povoação de Cubatão serão todas reguladas pelos planos de alinhamentos e nivelamentos adotados pela Câmara"70.

Tanto o código de 1847, como o de 1857, obrigavam os proprietários de terrenos alagadiços, na "área urbana" a drená-los e aterrá-los. Já havia, portanto, alguma preocupação com a saúde pública e com o destino dos

\footnotetext{
${ }^{70} \mathrm{Na}$ verdade, esses planos eram estabelecidos paulatinamente, sob a chancela da Câmara, à medida que aumentava a ocupação do sítio urbano.
} 
Legislação urbanística e segregação espacial nos municípios centrais da Região Metropolitana da Baixada Santista

esgotos. Segundo o código de 1857, estes deveriam ser afastados de forma a nunca serem lançados nas valas e córregos da povoação, sendo destinados às praias ${ }^{71}$, longe dos trapiches onde atracavam as embarcações.

\footnotetext{
${ }^{71}$ A praia a que se referia a legislação da época era o litoral do estuário, na área central da cidade de hoje, onde se construiu, nas últimas décadas do século XIX, a primeira etapa do Porto de Santos.
} 


\subsubsection{A legislação urbanística de Santos no Período do Café}

\subsubsection{A legislação e o Código Sanitário do Estado de São Paulo}

Os primeiros códigos de posturas não foram suficientes para impedir que, nas últimas décadas do século, com o súbito aumento da população, surgissem as epidemias que assolaram a cidade. A necessidade de enfrentar essas epidemias que obstaculizavam o desenvolvimento econômico de São Paulo calcado na exportação do café, inspirou no âmbito estadual o Código Sanitário do Estado, sancionado em 1894, com inspiração na legislação higienista francesa. Como decorrência deste, no mesmo ano foi promulgado o novo Código de Posturas de Santos, encaminhado, pela Câmara Municipal à Assembléia em 8 de maio de 1895, sendo sancionado por esta última e mandado publicar pela Câmara, em 2 de julho 1897. Com 307 artigos, distribuídos por 18 capítulos, este foi o primeiro código que estabelecia critérios edilícios e urbanísticos para Santos, com caráter tipicamente higienista.

Na verdade, com a proclamação da República iniciou-se um processo de transformação política e, conseqüentemente, Santos teve uma nova Câmara empossada em 29 de setembro de 1892. A função do executivo era desempenhada por um intendente geral. $O$ cargo de prefeito só surgiu em 1908, com a posse do penúltimo intendente geral, Coronel Carlos Augusto Vasconcelos Tavares, eleito para um mandato que durou até 1910 .

Uma das primeiras tarefas da nova Câmara foi a aprovação de um novo código que pudesse servir de instrumento no combate às graves condições sanitárias que se verificavam na cidade. Dessa forma, o Código de Posturas de 1897, de fato o segundo na história de Santos, tratava de variados assuntos atinentes às relações e costumes dos cidadãos na cidade, cuja população crescia rapidamente. Dentre esses temas, um dos mais privilegiados foi o das edificações e dos estabelecimentos de atividades econômicas, culturais e institucionais.

O Código de 1897 dispunha de normas para implantação de casas de espetáculo e divertimentos, cocheiras e estábulos, padarias, hotéis e casas de pasto ${ }^{72}$, açougues, comércio e indústria em geral, pedreiras e depósitos de materiais inflamáveis, matadouros, cemitérios, trânsito de veículos. A lei tratava com destaque da organização do corpo médico municipal e, principalmente, da higiene e sossego públicos e medidas de segurança geral.

Dos capítulos que dispunham das normas edilícias, merecem destaque o Capítulo I - Do alinhamento das ruas, edificações, edifícios e asseio, e o Capítulo VII - Do comércio e indústria. No Capítulo I pôde-se extrair grandes evidências da preocupação em romper com a ordem colonial, apagando seus vestígios nas construções e implantando-se uma nova ordem, inspirada nas modernas concepções que vinham do outro lado do Atlântico.

O embelezamento da cidade era, pois, ponto crucial do código. Em seu artigo XIX, pôde-se ler: "... hygiene, solidez, symetria e elegancia, não sendo admitidas as construções, que por seu máo aspecto ou fórma de architectura prejudiquem o embellezamentro da cidade" (grifo do autor). $\mathrm{O}$ artigo XI obrigava a impermeabilização dos pisos das

\footnotetext{
${ }^{72}$ As casas de pasto eram os restaurantes da época.
} 
edificações, o XII estabelecia a necessidade de que os edifícios em esquinas tivessem uma fachada "em ângulo", e o XIII estabelecia um recuo frontal máximo ${ }^{73}$ de $6 \mathrm{~m}$, para as novas edificações.

$\mathrm{O}$ artigo $\mathrm{XV}$, porém, é um dos mais interessantes, pois estabelecendo multa por desobediência, de $50 \$$, proibía as construções de "tapumes de zinco, madeira, cerca de arame ou espinhos, nas frentes das ruas ou praças, dentro do perímetro da cidade, assim como a construção de sacadas de ferro ou madeira nos prédios assobradados" (grifo do autor).

A proibição das sacadas de ferro e madeira, acima descrita, juntamente aos artigos XVIII, que vedava a utilização de argamassa de barro nas edificações, com o XXIII que impedia o uso de beirais sobre os passeios - obrigando a adoção de cimalha - e o XXIX, que proibia a construção de edifícios cobertos com ferro e zinco para uso de moradia, foram definitivos com o objetivo de suprimir a arquitetura colonial na paisagem da cidade e certamente provocaram o encarecimento das construções. Dessa forma, o novo código veio contribuir para a segregação da baixa renda para localizações fora do perímetro urbano de então.

O Código de 1897 em seu artigo XXXIV dispôs, porém, da construção dos "familistérios", solução para habitação popular preconizada pelos higienistas. Tal fato indicava que à época já se começava a perceber as mazelas da falta de

\footnotetext{
${ }^{73}$ Note-se que se tratava de recuo máximo, dispositivo oposto ao de hoje, em que são vedadas, na maior parte da cidade, construções no alinhamento.
}

condições de moradia adequadas para a baixa renda ${ }^{74}$. Essas edificações, segundo dispunha esse artigo, deveriam obedecer aos seguintes requisitos:

a) Serem construídas em lugar designado pela Prefeitura - o que podemos considerar um embrião de zoneamento segregacionista;

b) Disporem de uma área geral de $10 \mathrm{~m}$;

c) Terem altura de, pelo menos, $4,20 \mathrm{~m}$ cada casinha ou cubículo;

d) Disporem de uma área de $6 \mathrm{~m}$ para cada casinha ou cubículo:

e) Terem suas paredes rebocadas e caiadas, com o chão assoalhado ou cimentado;

f) Terem água e esgoto em abundância na área geral;

g) Terem todo o espaço murado com portão de entrada; e

h) Dispor de latrinas na proporção de uma para cada grupo de 5 casinhas ou cubículos.

O artigo XXXVII, por sua vez, dava a definição de um familistério: "Serão considerados familistérios prédios que sirvam de moradia a várias famílias, independentemente, em uma área comum, ou que tiverem quartos independentes nas mesmas condições".

Assim, os legisladores do final do século XIX tentavam equacionar a questão da moradia popular, mas o que se viu, como apontou LANNA (1996), foi que esse nível elevado de exigências edilícias contribuiu para fixar os trabalhadores de baixa renda e os escravos recém libertos na periferia da cidade de então.

\footnotetext{
${ }^{74}$ Segundo ANDRADE (1989: 210), "A lei provincial No 13, de 27 de março de 1886, estabelecia que os cortiços deviam ser de alvenaria, que era um reconhecimento oficial de sua existência".
} 
Ao procurar conferir níveis aceitáveis de salubridade às alternativas de moradia da classe trabalhadora, aumentavase o custo destas edificações, retirando-se a possibilidade de auferir grandes lucros para aqueles que as exploravam. Portanto, a legislação contribuía, ainda que indiretamente, para segregar a população de baixa renda em áreas fora dos limites oficiais da cidade. Esse certamente foi um dispositivo que muito contribuiu com a ocupação nos morros e Vila Macuco, os arrabaldes da virada do século, pela população de baixa renda.

Mais adiante, os artigos LI e LII estabeleceram critérios para a construção de novas fábricas e estabelecimentos comerciais, no centro da cidade, criando melhores condições para que a burguesia da época pudesse usufruir de um espaço "higienizado" e livre dos inconvenientes da nova sociedade que se formava. Como se viu no Capítulo 3 , tal intento não obteve sucesso, pois as classes de mais alta renda começaram a abandonar o centro, rumo à orla, na segunda década do século XX, em parte, para escapar dos impactos do comércio e serviços dessa região.

É interessante perceber que esses artigos delegavam à Prefeitura designar o local de implantação dessas atividades, constituindo-se num embrião de zoneamento, de forma bastante subjetiva, pois a lei não estabelecia critérios muito claros do que deveria ou não ser entendido como "os inconvenientes" por elas gerados e que justificavam uma localização apartada do núcleo central da cidade. De resto, nem mesmo os novos locais para estabelecimento dessas atividades eram mencionados no código.

No entanto, além do novo Código de Posturas, mais algumas leis foram de grande importância nesse final de século, para o estabelecimento da nova cidade preconizada pelos higienistas. A primeira, Lei $\mathrm{N}^{\circ} 24$, de 9 de junho de 1894, estabeleceu os limites da cidade, o que mais tarde seria essencial para a nova política de segregação. É importante ressaltar que os limites previstos incluíam quase toda a atual zona leste da cidade atual e os morros, no perímetro urbano. No entanto, na prática, as áreas dos morros e a periferia do centro, nunca tiveram o mesmo tratamento da área central, no que dizia respeito à fiscalização de construções precárias. Estas construções foram toleradas, via de regra, desde que estivessem fora do perímetro "real" da cidade, que era o centro de então.

A segunda, Lei $\mathrm{N}^{\circ} 46$, de 17 de outubro de 1894, visava transformar os cortiços em "casas higiênicas" e foi fundamental para o exercício da polícia sanitária e a demolição dos mesmos no centro da cidade. Na verdade, a lei dava prazo de 60 dias para a reforma dos cortiços, sob pena de multa de $50 \$ 000$, além de demolição. Não é difícil imaginar o impacto dessa lei e suas conseqüências extremamente violentas, como descreveu LANNA (1996). Tal como ocorreu em outras cidades, como São Paulo e Rio de Janeiro, visava-se eliminar os cortiços da área "visível" da cidade.

A Lei $\mathrm{N}^{\circ}$ 58, de 3 de novembro de 1894, tratava da autorização para a construção de vilas operárias. Pretendiase com isso, dar alternativa para a provisão de habitação popular. No entanto, como se pretende demonstrar neste trabalho, as vilas operárias nunca foram de fato uma opção para a população de baixa renda, em função de seu custo fora do alcance dessa parcela da sociedade. 
Como apontou NUNES (2001: 39), o sinônimo para cortiço era familistério, termo adotado no Código de Posturas de 1897. Havia a previsão de "substituir os cortiços por familistérios destinados à pobreza", construídos pela municipalidade ou por concessão. Os cortiços eram uma fonte de renda para muitos munícipes, que alugavam casinhas de madeira, enfileiradas nos fundos dos lotes, em que a falta de condições de higiene era imensa.

A Lei $\mathrm{N}^{\circ} 82$, de 12 de agosto de 1896, introduziu, pela primeira vez a figura do recuo mínimo, exigindo que as novas construções na praia da barra fossem recuadas em $10 \mathrm{~m}$ e, nas avenidas Anna Costa e Conselheiro Nébias ${ }^{75}, 7$ $\mathrm{m}$. Era esse um instrumento fundamental para conferir à paisagem urbana, uma nova aparência, mais condizente com os preceitos higienistas. No entanto, a obrigatoriedade do recuo numa cidade eminentemente horizontal obviamente reduziu o aproveitamento dos lotes, restringindo - acesso da população de baixa renda aos imóveis construídos nessas avenidas, o que pode não ter sido por acaso.

A Lei $N^{\circ} 83$, de 17 de setembro de 1896, eliminou a exigência de recuo para os edifícios construídos em bloco, no Centro, sendo o prenúncio da diferenciação no padrão urbanístico preconizado para a ocupação das áreas próximas à orla marítima, ao longo dos eixos das avenidas Conselheiro Nébias e Anna Costa, bem como da Praia da

${ }^{75}$ Essas avenidas foram as primeiras ligações consolidadas entre 0 centro e a orla, e até hoje têm este papel. Portanto, era fundamental garantir-lhes um aspecto nobre e foi o que se viu, pois as mesmas foram ocupadas por palacetes da classe alta de então, alguns dos quais subsistem até os dias atuais.
Barra. Nestas, o padrão previsto era o de baixa densidade, com o emprego de recuos generosos.

Foi a Lei $N^{\circ} 94$, de 15 de março de 1897, no entanto, que estabeleceu o alinhamento a ser adotado para a abertura de novas ruas, no processo de expansão da cidade em direção à Barra. Propunha-se um reticulado monótono, típico do traçado adotado para as novas cidades nos Estados Unidos da América do Norte (ver Figura 29). A planta foi elaborada por técnicos da municipalidade, baseada em levantamento realizado anteriormente do qual levantaram-se algumas hipóteses, como afirmou NUNES (2001: 43). Pode ter sido realizado por repartição estadual, segundo BRITO (Vol. II, 1943); pelo engenheiro Manoel Ferreira Garcia Redondo, contratado pela Câmara na década anterior; ou pela Comissão Ferraz, para o projeto do engenheiro norte-americano Estevam Fuertes ${ }^{76}$.

Em ANDRADE (1989: 184), podemos ler acerca da polêmica entre a Câmara e Saturnino de Brito, quando da apresentação de seu plano, que o reticulado proposto era "tão medíocre que nem mesmo durante a polêmica, ousouse compará-lo com o plano" de Saturnino. Em seguida, ainda sobre o plano da Lei $\mathrm{N}^{\circ}$ 94, a autora escreveu: "o projeto não respeitava nada, tanto ação humana quanto natureza".

No entanto, cabe ressaltar que, em sua concepção do plano para Santos (ver Capítulo 3), Saturnino de Brito já sugiria o arcabouço de um código urbanístico, como se pôde verificar em ANDRADE (1991: 62):

\footnotetext{
76 O engenheiro Fuertes, embora não fosse especialista em saneamento, foi contratado pelo Governo, tendo curta permanência em Santos.
} 
"Quanto á legislação urbanística, Brito propõe diversos instrumentos jurídicos, formulando tanto uma legislação sobre vias particulares, como também disposições legislativas complementares às que regulavam as expropriações por utilidade pública. Em relação à primeira, Brito especifica de modo detalhado as dimensões do conjunto de elementos que imporiam uma padronização ao desenho urbano, como por exemplo: 'As ruas terão a largura mínima de $7 \mathrm{~m}$ quando os prédios forem construídos pelo menos a 2,50 $\mathrm{m}$ para dentro do alinhamento, ficando à frente uma varanda, alpendre ou jardim de largura igual ou superior a 2,50 m; quando os prédios tiverem de ficar no alinhamento da rua, esta terá largura igual ou superior a $12 \mathrm{~m}$; em qualquer dos casos a parte central pode ter a largura mínima de $5 \mathrm{~m}$, sendo o excedente destinado aos passeios laterais. Nenhuma construção será executada com altura superior à largura da rua, contando-se aquela altura do passeio à parte alta do pano da platibanda, ou ao beiral dos telhados em saliência ${ }^{, 77}$. Outro instrumento legal que Brito propõe é a contribuição de melhoria, aplicando-a em particular no caso de execução dos canais e avenidas, 'para custear as obras que, embora de interesse geral, beneficiem diretamente ou mui proximamente certas propriedades",78.

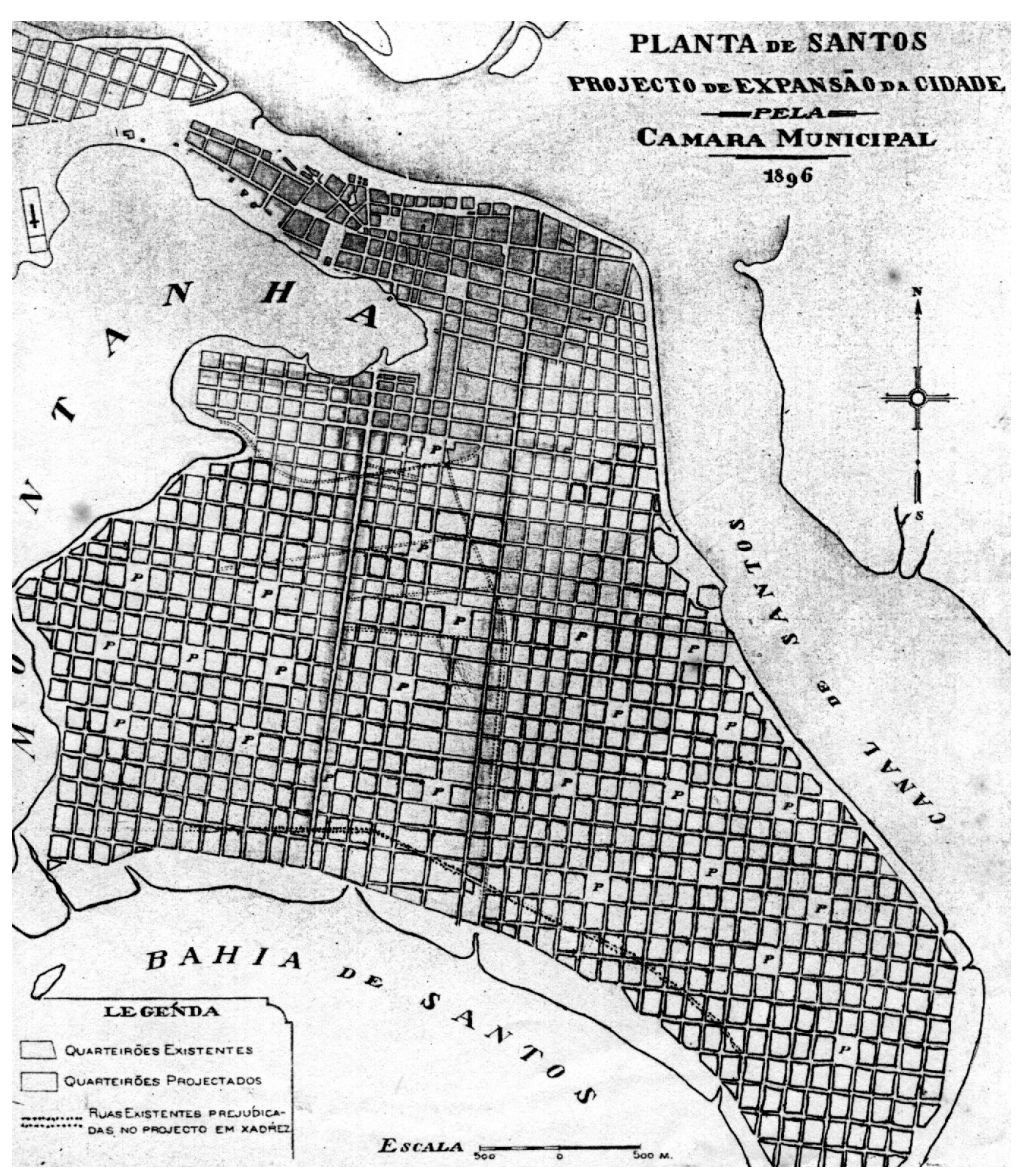

Figura 29 - Arruamento do Projeto de Expansão da Cidade de Santos, elaborado em 1896 e aprovado pela Câmara Municipal em 1897. É interessante observar que as quadras mais escuras eram as efetivamente ocupadas até então. Fonte: ANDRADE (1989).

\footnotetext{
77 BRITO (1943: 229), apud ANDRADE (1991: 62).

${ }^{78}$ BRITO (1943: 128), apud ANDRADE (1991: 62).
} 


\subsubsection{A legislação do início do século $X X$ até o Código de Construções de 1922}

Nas primeiras décadas do século XX a legislação urbanística santista claramente priorizou a substituição da cidade colonial pela cidade moderna, de inspiração européia. As exigências e incentivos contidos nas leis apontavam para o surgimento de uma arquitetura mais adequada aos novos princípios de moralidade e higiene, tão necessários à afirmação da nascente burguesia.

Era necessário padronizar as edificações, controlar seu uso, intervir no desenho da cidade, criando ambientes propícios ao desenvolvimento de uma sociedade sadia, livre das epidemias e que em nada lembrasse o passado recente. Em ANDRADE (1989: 132) pode-se ler: "O progresso é incompatível com a decadência física e se compraz com o novo. $O$ velho tende a se identificar com a sujeira e desleixo e, como tal, é inaceitável pelo mundo moderno".

Esse espírito esteve presente até a sanção do Código de Construções do Município, Lei $\mathrm{N}^{\circ} 675$, em 1922, quando se consolidou o primeiro zoneamento de uso da cidade (ver Mapa à p. 125).

Dentre estas leis edilícias do princípio do século, anteriores ao Código de 1922, podemos destacar, principalmente as seguintes:

A Lei $N^{\circ} 217$, de 11 de abril de 1906, que vedou a construção de estabelecimentos de "vendas, quitandas, açougues, ou lojas de qualquer outro ramo de negócio", na rua Sete de Setembro, no trecho entre a rua Brás Cubas e av, Conselheiro Nébias. Esse foi, também, um embrião de zoneamento, e a área em que a proibição incidia, o florescente bairro da Vila Nova, era ocupada pela burguesia que começava a estabelecer-se na periferia do centro, fugindo dos transtornos provocados pela vida comercial cada vez mais intensa naquela região da cidade. Tratava-se então de delimitar alguns territórios não comerciais na cidade e este foi provavelmente o primeiro.

Sobre o bairro da Vila Nova (ver Figura 30), SANTOS (1996: 141) escreveu:

"Era Santos uma pequena cidade que começava a se expandir de sua primitiva área, quando sua população mais abastada, procurando sair da velha área, que já se popularizava, foi-se concentrando entre o Paquetá a atual avenida Campos Sales, entre a avenida Senador Feijó e a faixa portuária, cujo bairro se situa, hoje, entre os bairros do Centro, Paquetá, Vila Matias e faixa do porto. Passou a ser, então, o bairro mais moderno e mais "chique" de Santos, e em se tratando de um novo núcleo residencial era chamado de "Vila Nova" e assim permaneceu" (grifo do autor).

A lei $\mathrm{N}^{\circ}$ 235, de 10 de outubro de 1906, proibia a construção de prédios para o estabelecimento de "açougue, quitanda e congêneres, nas esquinas, em todo o perímetro urbano". Pode-se interpretar esse dispositivo como mais uma tentativa de implantação de um padrão mais sofisticado e elegante na cidade que se expandia, de acordo com os preceitos do moderno urbanismo da virada do século.

A lei $N^{\circ} 265$, de 5 de junho de 1907, isentava de imposto os prédios que "se construírem nas avenidas Anna Costa e 
Conselheiro Nébias durante cinco anos" e determinava o prazo de um ano para que os capinzais fossem eliminados nestas avenidas. Da mesma forma que se pretendia suprimir o ar de arrabalde predominante então, na maior parte da extensão dessas avenidas essa lei incentivava novas construções e, associada a outras, procurava estabelecer um novo território para as elites, rumo à orla. Esses eixos de expansão foram os mais importantes e sofisticados no início do século, em que predominaram os casarões de famílias de alta renda.

A Lei $\mathrm{N}^{\circ} 322$, de 28 de agosto de 1908, proibia a construção, no perímetro urbano, de prédios com "dimensões - largura - inferiores" à propugnada para os seis tipos padrão de edificação definidos pela Lei $\mathrm{N}^{\circ} 235$, de 10 de outubro de 1906. Essa lei regulamentava padrões de edificações, os quais deveriam preferencialmente ser adotados pelos construtores, daquele momento em diante. Eram desenhos de edifícios que rompiam totalmente com o padrão colonial de arquitetura, com fachadas ecléticas, onde os beirais eram suprimidos e os adornos dos vãos e cimalhas bastante valorizados.

Não por acaso essa lei liberava da exigência as construções fora do perímetro urbano, mais uma vez demarcando o território da cidade moderna que se queria construir. Nas avenidas Anna Costa e Conselheiro Nébias, nesta última a partir da rua Bittencourt - início do bairro da Vila Nova - até a "barra" e nos edifícios de frente para esta, a exigência era de que os prédios tivessem uma frente mínima de $8 \mathrm{~m}$. Tanto nessas avenidas como na praia da barra, e em menor grau, em todo o perímetro urbano, o estabelecimento de uma largura mínima para as frentes dos lotes contribuiu para dificultar mais ainda o acesso das classes de menor renda à habitação nesse território da Santos moderna.

A Lei $N^{\circ} 331$, de 21 de outubro de 1908, "aperfeiçoou" a Lei $N^{\circ}$ 322, limitando as frentes dos edifícios, a serem construídos nas avenidas Anna Costa, Conselheiro Nébias e na barra, a $6 \mathrm{~m}$ no mínimo, estabelecendo um recuo lateral mínimo de $2 \mathrm{~m}$, em ambos os lados. Era provavelmente a primeira vez na legislação santista, que surgia a figura do recuo lateral e na prática essa nova limitação aumentou em mais $2 \mathrm{~m}$ as dimensões exigidas na lei $N^{\circ} 322$. Se essa última lei limitava o acesso da classe trabalhadora a essas áreas da cidade, a nova lei ampliava essa limitação.

A Lei $\mathrm{N}^{\circ}$ 341, de 10 de março de 1909, estendia as exigências da Lei $\mathrm{N}^{\circ} 322$ para as construções a serem feitas ao longo das avenidas que margeavam os novos canais de drenagem, então em implantação. Essa lei estabelecia, ainda, um recuo frontal obrigatório de no mínimo $5 \mathrm{~m}$, para as construções na avenida Ana Costa e ao longo do Canal 3 - canal da rua Brás Cubas e avenida Washington Luiz. Pouco a pouco, mais exigências desse tipo atingiam as principais avenidas do plano de Saturnino, demarcando mais claramente áreas de exclusão na cidade.

A Lei $N^{\circ} 374$, de 5 de abril de 1910, isentava da cobrança de impostos os empreendedores da Vila Ablas, loteamento construído entre a avenida Conselheiro Nébias e o cais, na área mais ao sul da Vila Nova, hoje bairro da Vila Mathias (Ver Figura 30). A intenção era incentivar a implantação de um bairro operário, mas a mesma lei exigiu que os lotes tivessem $10 \mathrm{~m}$ de largura, no mínimo e estabeleceu recuo frontal de $5 \mathrm{~m}$ para todas as construções ali edificadas. 
Essas condicionantes, somadas à falta de financiamento, dificultaram a fixação do operariado no novo bairro, da mesma forma que veio a ocorrer com a Vila Belmiro. Ou seja, a municipalidade passara a subsidiar empreendimentos tidos como destinados à baixa renda, que na verdade destinavam-se à classe média.

A Lei $\mathrm{N}^{\circ}$ 444, de 11 de janeiro de 1911, estendia os dispositivos da Lei $N^{\circ} 331$, para a "zona" situada entre as avenidas Anna Costa e Conselheiro Nébias, e a rua Alexandre Herculano e a praia da barra, proibindo nessa área a construção de "estábulo, cocheira, depósito de inflamáveis e botequins". Era a expansão do zoneamento de uso embrionário, e provavelmente a primeira vez que o termo "zona" foi citado na legislação santista, com tal conotação. De resto, vale destacar que essa zona situavase ao sul da estrada de ferro São Paulo Railway - depois E. F. Sorocabana ${ }^{79}$ - nos limites dos atuais bairros do Gonzaga e Boqueirão, áreas de alta renda da cidade. Certamente a intenção era delimitar uma área, a exemplo do que se tentou para a Vila Nova, livre dos transtornos típicos daquelas atividades descritas na lei e com lotes de maior dimensão, restringindo, assim, o perfil econômico de seus futuros ocupantes.

Dentre todas as leis que precederam o Código de Construções de 1922, no tocante ao interesse específico deste trabalho, uma das mais importantes foi a Lei $\mathrm{N}^{\circ} 460$, de 26 de abril de 1911, que estabelecia critérios e locais para as moradias em madeira. Como afirmou CALDATTO (1998) eram os chalés de madeira a moradia típica da população de baixa renda. Essa lei delimitava áreas onde

\footnotetext{
79 Ramal atualmente administrado pela Companhia Paulista de Trens Metropolitanos - CPTM
}

os chalés poderiam ser construídos, distintas daquelas onde foram implantados os empreendimentos imobiliários de alta e média renda.

Essas áreas eram equivalentes aos espaços menos "nobres" do extenso território da Zona Leste da Ilha, localizados entre o centro e a orla marítima, limitados pelas ruas paralelas à orla, excluindo-se os principais eixos viários da época e, também, a Bocaina - atual Distrito de Vicente de Carvalho, em Guarujá - e "em outros pontos afastados da cidade".

Ao mesmo tempo a lei estabelecia dimensões mínimas para os compartimentos do chalé e demais exigências construtivas, de maneira a garantir um mínimo de salubridade para as construções. Tratava-se de controlar a qualidade da moradia popular daquela época, mas afastá-la das áreas ocupadas da alta renda, no período. Explicitavam-se, assim, os dispositivos de exclusão social na legislação santista.

Em relatório da Diretoria de Obras e Viação, apresentado à Câmara Municipal de Santos, em 30 de abril de 1919, em que se analisava a atividade da Companhia Construtora de Santos $^{80}$, maior empresa do ramo no início do século, discorria-se sobre a importância da construção de moradias populares. Nesse texto podemos encontrar significativa referência aos chalés de madeira, que dá a exata medida de como os mesmos eram vistos pela classe dominante da época (1919: 103):

\footnotetext{
${ }^{80}$ A Companhia Construtora de Santos foi uma empresa de capita importância para o desenvolvimento de Santos e região. Responsável pela construção de inúmeras obras de vulto, era de propriedade do
} empresário Roberto Simonsen. 
"Bom será que se acentue este movimento - de construção -, e isto não só para a construção de grandes prédios, de que Santos tem número muito escasso. Como para a de casas de moradia, especialmente de pequeno aluguel, para família de modestos recursos, de cuja falta se ressente extraordinariamente a cidade, sendo esta a causa primária de surgirem, como cogumelos, da noite para o dia, os chalés de madeira, já hoje inumeráveis, e que, se vêm ao encontro de verdadeira e insofismável necessidade da população, por um lado são muito precários sob o ponto de vista da higiene e do conforto, podendo se tornar, pelo fato de não serem regularmente esgotados, uma séria preocupação em ocasiões de epidemias".

É precioso este depoimento, pois além de ter demonstrado que a questão da habitação para a baixa renda persistia sendo um grave problema, a despeito do desenvolvimento da cidade apontava para a necessidade de regulamentação daquela que se afigurava como sendo a principal alternativa, em termos de tipologia habitacional, para essa classe social.

A Lei $N^{\circ} 477$, de 11 de outubro de 1910, estabelecia a permissão de edificar prédios de três pavimentos, na Rua $\mathrm{XV}$ de Novembro, o centro do comércio cafeeiro de então. Esse dispositivo permitia adensar o ponto mais nevrálgico do centro da cidade, o que provavelmente foi uma exigência do mercado imobiliário da época.

A Lei $N^{\circ} 489$, de 3 de janeiro de 1912, foi um verdadeiro embrião do Código de Obras de 1922. Essa lei redefiniu os recuos frontais e laterais exigidos para as construções nos lotes ao longo dos principais eixos viários, onde se estabelecia a classe de alta renda - avenidas Ana Costa, Conselheiro Nébias e da praia - e na zona criada pela Lei $n^{\circ}$ 444. Estabelecia, ainda, dimensões mínimas para aposentos e a exigência de iluminação e ventilação dos mesmos; e criava a exigência de recuo frontal de $2,50 \mathrm{~m}$ para os sobrados construídos nas demais áreas do perímetro urbano, entre outras coisas. A tentativa de controlar o espaço construído chegara ao seu ponto máximo, antes do Código de 1922, contribuindo para a definição de um padrão urbanístico que perdurou nas primeiras décadas do século XX e, ainda hoje, pode ser visto nas ruas de Santos. Pouco a pouco, à medida que a cidade crescia em direção à praia, esta ganhava uma aparência mais cosmopolita, perdendo o aspecto acanhado de seu sítio colonial.

Dentre as tentativas de intervenção na questão da habitação do operariado, já naquela época um problema de grandes dimensões, a Lei $\mathrm{N}^{\circ} 501$, de 31 de julho de 1912, foi marcante pelo fracasso de seus objetivos. Esse dispositivo autorizou a Prefeitura a contratar empresa para construir moradias para operários. Estas moradias deveriam ser construídas em conjuntos de 100, nunca menos de 200, e mais que 1000. Pela falta de instrumentos federais de financiamento, a Lei $N^{\circ} 501$ autorizava os "contratantes" a arrendar as unidades, com juros de $10 \%$ ao ano, ou vendêlas com juros de $12 \%$ ao ano. Estabelecia, ainda, valor locatício máximo, para o caso do empreendedor preferir aluga-las, de 60\$000 - sessenta reais. Da mesma forma, ficava limitado o número de moradias por renque de 8 unidades, isoladas por afastamentos laterais de $4 \mathrm{~m}$. 


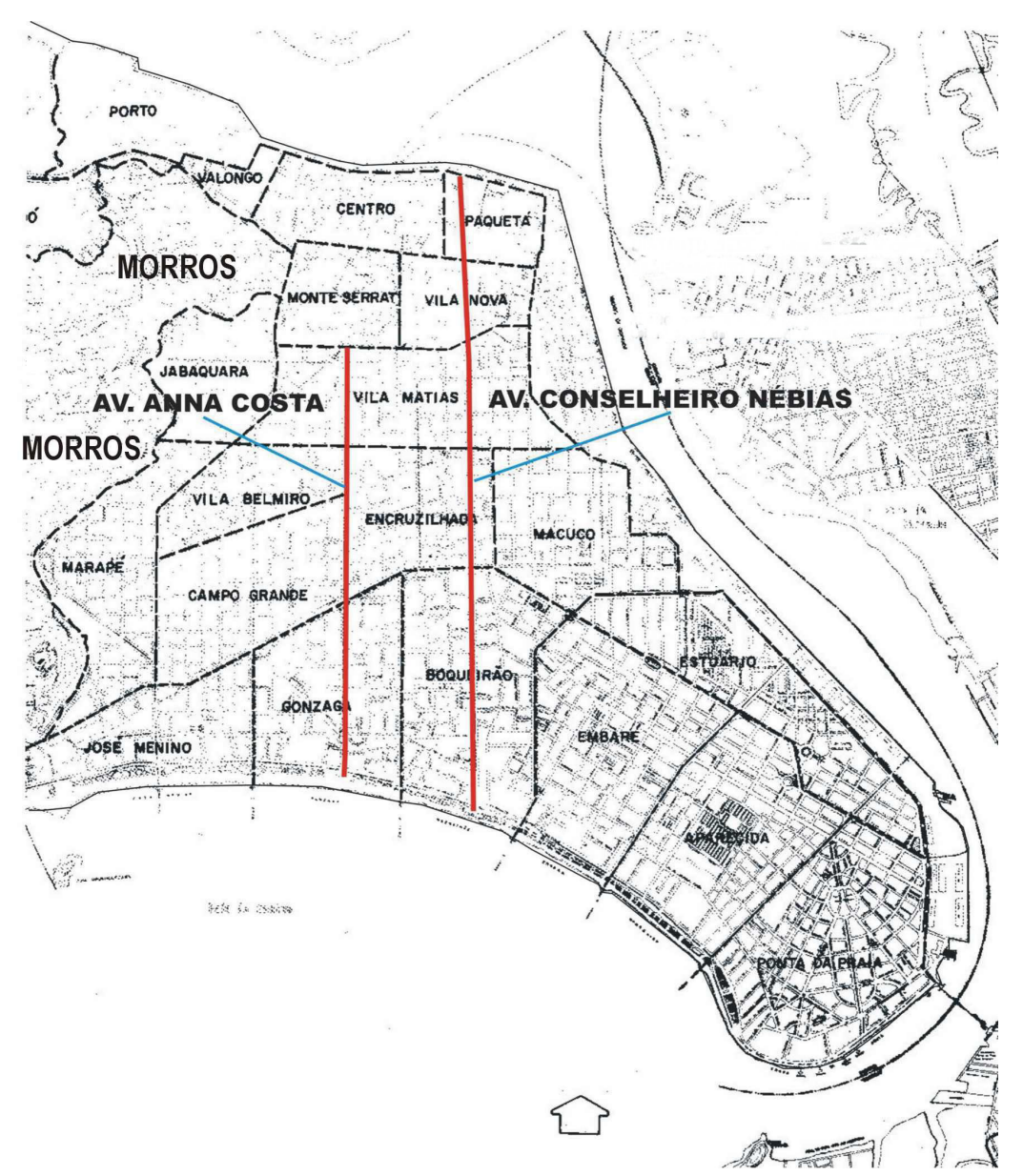

Figura 30 - Divisão em bairros e principais eixos viários das áreas centrais e Zona Leste da área insular do município de Santos, cujo processo de ocupação encerrou-se ao fim do Período Desenvolvimentista. Fonte: Prefeitura Municipal de Santos, 1968.

Esta lei introduziu, provavelmente pela primeira vez na legislação santista, a figura da taxa de ocupação, pois exigia que o conjunto dispusesse de uma área livre mínima de 3 vezes a área construída, em cada quadra. Pelas condições de financiamento, principalmente, esse instrumento excluiu parcela considerável do operariado do acesso a esses conjuntos, mas foram especialmente as dimensões mínimas exigidas por cômodo, que bloquearam esse acesso. Eram as seguintes estas dimensões mínimas: $40 \mathrm{~m}^{2}$ para dormitórios, $50 \mathrm{~m}^{2}$ para sala, $22 \mathrm{~m}^{2}$ para cozinha e $8,5 \mathrm{~m}^{2}$ para a sala de banhos. Não é difícil conceber que a intenção da prefeitura, por melhor que tenha sido, foi malograda. $\mathrm{Na}$ verdade, quando construídos esses conjuntos acabaram sendo ocupados pela classe média, desvirtuando suas finalidades.

O Código de Construções do Município, Lei $N^{\circ} 675$, de 28 de junho de 1922, foi o primeiro código de Santos a tratar, separadamente, a produção do espaço construído. $\mathrm{Na}$ realidade, esse código reuniu o conjunto de disposições edilícias existentes até então, com algumas pequenas alterações, mas aprofundou principalmente os critérios para manutenção da higiene nas edificações e quanto ao aspecto de segurança.

Uma série de artigos publicada entre março e abril de 1918, no jornal Gazeta do Povo, revela a polêmica em torno da elaboração deste código. Na verdade, a proposta original, de autoria do engenheiro da municipalidade, Silva Telles, chefe da Diretoria de Obras e Viação da Prefeitura, enfrentou séria oposição de categorias profissionais, por tentar regulamentar a atividade de projeto e construção, determinando quais tipos de obras poderiam ser executadas por cada tipo de profissional - construtores, arquitetos e engenheiros. 
O projeto de lei dividia os profissionais do setor da construção em duas categorias: de primeira e de segunda, delimitando o espaço de ação profissional de cada uma, segundo o tipo de obra. À primeira categoria pertenceriam todos aqueles profissionais, como engenheiros e arquitetos, diplomados, ou os não diplomados de "notória competência". À segunda pertenceriam aqueles que tivessem "ao menos um ano de prática".

O projeto limitava a atuação dos profissionais da segunda categoria à construções de até três pavimentos ${ }^{81}$, bem como "fazer e refazer construções simples". Esta tentativa de reserva de mercado, que deve ter interessado empresários de maior porte, despertou a oposição de parte da sociedade e da imprensa, suscitando uma série de artigos na Gazeta, questionando o projeto do Código.

No primeiro destes artigos, publicado em 21 de março daquele ano, pode-se ter, contudo, uma avaliação clara das forças políticas que influíam na elaboração da regulação urbanística da época. O referido artigo dava conta da nomeação, pelo presidente da Câmara, de uma "grande comissão de dezenove membros" que deveria dar a última palavra sobre o projeto.

Mais adiante são relacionados os membros da comissão: Inspetor da Saúde do Estado, chefe da repartição de Saneamento, um diretor e o presidente da Companhia Construtora de Santos, consultor jurídico da Municipalidade,

${ }^{81}$ É importante frisar, segundo foi possível perceber por meio da leitura de periódicos da época, que o conceito de pavimento mudou na virada do século. Para os efeitos de contagem do número de pavimentos, diferentemente do século XIX e do período atual, o térreo não era contabilizado. presidente da Associação Predial ${ }^{82}$, dois engenheiros de renomada atuação - Edmundo Krug e Alberto Monteiro de Carvalho, dois médicos de renome - Alberto de Moura Ribeiro e Olyntho Rodrigues Dantas, três membros da Comissão de Justiça da Câmara, três da de Finanças, e três da de Obras Públicas e Viação - totalizando nove vereadores.

Ora, ficava evidente a falta de participação, àquela época, de representantes das classes trabalhadoras, o que foi a prática até 0 final do período denominado Desenvolvimentista $^{83}$. Assim, a discussão da reforma do Código de Posturas, que acabou por resultar da elaboração do código de Construções de 1922, dava-se num círculo de representantes, em sua maioria, dos extratos de alta renda da cidade. Este fato é importante para que se possa compreender o processo político e ideológico de elaboração deste e dos demais códigos e planos de Santos.

O texto da Lei acabou por suprimir a divisão entre duas categorias de profissionais, mais introduziu a obrigatoriedade de que estes obtivessem o registro na Prefeitura, dando para isso um prazo de seis meses, findo o qual o profissional não poderia mais requerer a aprovação ou licença para construir uma edificação. Venceu, portanto, a pressão política dos pequenos e médios construtores.

\footnotetext{
${ }^{82}$ A Associação Predial de Santos foi, possivelmente, a primeira e uma das mais bem sucedidas cooperativas de Santos, tendo operado na área de construção habitacional, produzindo na região, até o período da segunda guerra mundial, cerca de 2.300 unidades habitacionais.

${ }^{83}$ Como será visto no item 4.1.3., o Conselho Consultivo do Plano Diretor Físico do Município de Santos - COPLAN, de 1968, era composta por representantes das mesmas classes sociais, tal como no início do século.
} 
Quanto ao espaço urbano propriamente dito, o código manteve os dispositivos já criados pelas leis anteriores, tais como recuos, dimensões das frentes dos lotes e outros. No entanto, a nova lei foi mais clara ao determinar um novo perímetro urbano, suburbano, de transição e rural, em seu Capítulo $2^{\circ}$, descrevendo seus limites e vinculando a estes alguns usos e padrões construtivos peculiares.

O perímetro urbano correspondia aos atuais bairros do Saboó, este entre o Valongo e o rio Saboó - atual rio Lenheiros, Valongo, Centro, Paquetá e parte da Vila Mathias (ver Figura 31), entre o Centro e as ruas Lucas Fortunato e Luiza Macuco, bem como os terrenos com frente para as avenidas Anna Costa e Conselheiro Nébias, e os com frente para as praias da Barra.

O perímetro suburbano, correspondia às áreas da atual Zona Leste da área insular do Município, entre o Canal 1 e morros, entre aquele canal e a avenida Anna Costa, entre esta e a avenida Conselheiro Nébias, a entre esta última e o cais, ao sul do perímetro urbano, limitando-se, ao leste, pela faixa de $50 \mathrm{~m}$, do alinhamento par do Canal 4, até o fundo dos terrenos de frente para a orla marítima e, ainda, na área da atual Zona Noroeste, compreendia os atuais bairros da Alemoa, Chico de Paula e parte do Santa Maria, entre a atual av. Nossa Senhora de Fátima, o Matadouro Municipal - atual SESI do bairro Santa Maria - e a extinta linha da São Paulo Railway, que cortava os terrenos onde hoje se situa o Jardim Botânico, na Zona Noroeste.

Portanto, os lotes ao longo das avenidas Anna Costa, Conselheiro Nébias, Canais 1 e 4 e praia da barra, de grande valorização imobiliária, também estavam contidos no perímetro urbano. O perímetro de transição consistia na área hoje correspondente aos bairros da Ponta da Praia, Aparecida, Estuário e Embaré, ou seja, entre o Canal 4, o fundo dos terrenos de frente para a Barra e o cais, bem como a imensa maioria da atual Zona Noroeste, que não estava contida no perímetro suburbano, e nas parcelas ocupadas das áreas da Bocaina e Cubatão - que a esta época pertenciam ao município de Santos. Já o perímetro rural incluía as áreas restantes: morros, área continental de Santos e parcelas não ocupadas dos atuais municípios do Guarujá e Cubatão.

A despeito dos perímetros definidos, o Código estabeleceu um zoneamento de uso, o primeiro explicitado na legislação santista, de cunho bastante simples, mas que não correspondeu exatamente ao recorte dos perímetros. Foram criadas as Zonas Comercial, Residencial e Industrial. Não era um zoneamento rígido. Pelo contrário, o Capítulo $5^{\circ}$, em seu artigo $18^{\circ}$, assim dispunha: "Para maior eficiência dos diversos serviços municipais, melhor aproveitamento dos terrenos pelos proprietários, máxima comodidade dos habitantes, regularização dos transportes e, especialmente, para garantia das condições de higiene desejáveis, devem, tanto quanto possível, ser distintas as zonas de habitação das do comércio e da indústria" (grifo do autor).

A leitura desse artigo permite supor que, certamente os critérios para liberação do direito de edificar, segundo a área da cidade, poderiam variar de forma bastante subjetiva, o que contrastava com o rigor exigido na mesma lei, no tocante à iluminação, insolação, ventilação e dimensões dos cômodos, bem como quanto ao cálculo das estruturas de concreto, uma vez que em seu Capítulo XI as definições destes elementos para cálculo eram 
apresentadas na forma de um verdadeiro compêndio de calculo estrutural.

Os limites da Zona Comercial eram, praticamente, os correspondentes aos atuais bairros do centro, Valongo, Paquetá e Saboó, este entre o Valongo e o rio Saboó - rio Lenheiros. A Zona Residencial situava-se imediatamente ao sul da Comercial, entre os morros, orla, Canal 4 e cais, deixando fora os atuais bairros do Estuário, Embaré, Aparecida e Ponta da Praia. A Zona Industrial correspondia à Zona Noroeste, a partir do rio Saboó (ver mapa à p. 125).

O código vedava a construção de indústrias "insalubres, perigosas ou ruidosas", na Zona Comercial. Na Zona Residencial proibia industrias "nocivas, insalubres" e tolerava as "ruidosas, desde que devidamente isoladas" (grifo do autor). Nestas zonas eram permitidas padarias, cervejarias, oficinas mecânicas, correarias e refinações de açúcar. Especificamente na Zona Residencial era permitido construir serraria e garagens de grande porte. Eram esses, pois os enquadramentos das indústrias segundo seu porte.

Outra novidade do código era a exigência da apresentação de "plano de construção" detalhado e documento do terreno para a concessão da licença para edificar, sendo que os construtores e arquitetos deveriam ter registro na Prefeitura. Esta lei criou, ainda, a figura da Carta de Habitação, mais conhecida como "habite-se".

Os critérios para edificar eram aplicáveis, sobretudo nos perímetros urbano e suburbano, sendo exigidos, apenas, fora dessas áreas, cuidados especiais, já em vigor antes da lei, para a construção de chalés de madeira, no perímetro de transição. Essa "liberalidade", que contrastava com um alto rigor de exigências para os dois primeiros perímetros, seguramente contribuiu para demarcar padrões de urbanização e construção nessas regiões, incidindo no valor imobiliário dessas áreas. Dessa forma, o Código de 1922 reforçou dispositivos de exclusão, uma vez que as classes de baixa renda passaram a ter maiores dificuldades para habitar nos perímetros urbano e suburbano. Não por acaso, a partir dessa época ocorreu uma acentuada proliferação de chalés nos bairros junto ao estuário e nos morros.

Essa lei continha algumas contradições típicas de um período em que ainda se buscava remover os vestígios da cidade colonial e os cortiços. O artigo $47^{\circ}$ assim dispôs: "A mais ampla liberdade é facultada quanto ao estilo e à forma da arquitetura dos edifícios, cabendo, porém, à Prefeitura opor-se à construção dos projetos que, flagrantemente atentarem contra a estética" (grifo do autor). Entende-se, assim, que os edifícios deveriam obedecer ao estilo moderno, de inspiração européia, banindo o uso de repertório estilístico e materiais típicos da arquitetura colonial, garantindo a salubridade indispensável para a construção de uma cidade higiênica.

Por fim, cabe destacar que menos preocupados com a densidade habitacional, que com a ventilação e insolação, os legisladores estabeleceram limites para a altura dos edifícios, os quais variavam segundo a localização e largura da via, de forma que no Centro, onde os prédios podiam ser mais altos, a altura máxima admitida era de $18 \mathrm{~m}$, para construções em vias com largura superior a $10 \mathrm{~m}$, e de 14 $\mathrm{m}$, para as vias mais estreitas. $E$, ainda, nos principais eixos viários a largura mínima dos lotes mantinha-se em $6 \mathrm{~m}$, mais os recuos laterais obrigatórios, que poderiam variar 
entre $1,5 \mathrm{~m}$ e $2 \mathrm{~m}$, segundo a via em que o terreno estivesse localizado.

No entanto, logo após sua promulgação o novo Código de Construções teve sua aplicação suspensa, provavelmente em função das alterações que trazia para a vida da sociedade santista terem sofrido algumas resistências. Mas logo em seguida, pela lei $N^{\circ} 679$, de 9 de outubro de 1922, a suspensão foi tornada sem efeito e com modificações mínimas o código voltou a vigorar. 


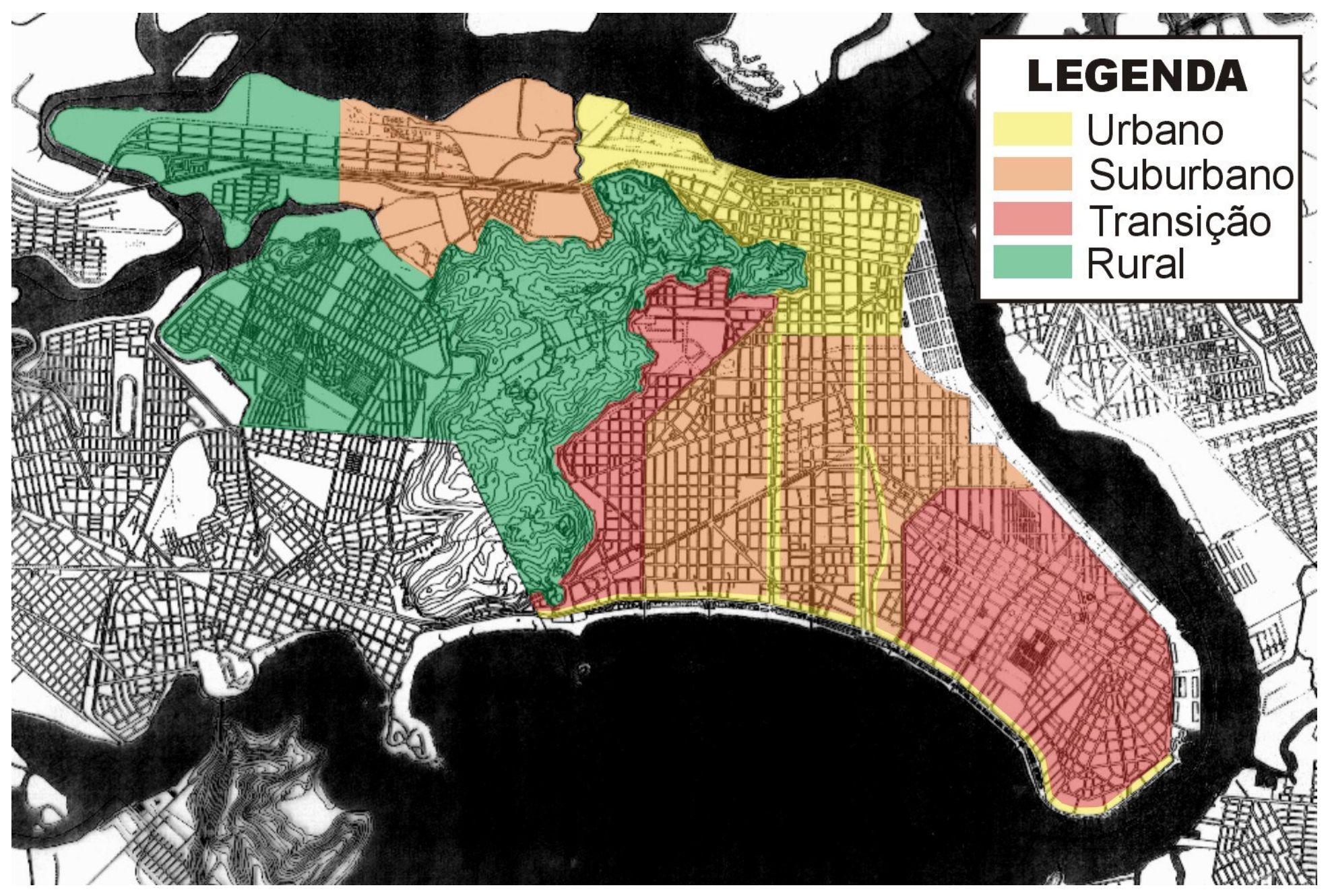

Figura 31 - Perímetros das zonas urbana, suburbana, de transição e rural, na área insular do Município, definidos pelo Código de Construções de 1922, sobre base cartográfica de 1968. Os limites das zonas foram desenhados a partir da interpretação das descrições apresentadas no texto da lei, uma vez que a planta não foi localizada no Arquivo Histórico de Santos. 


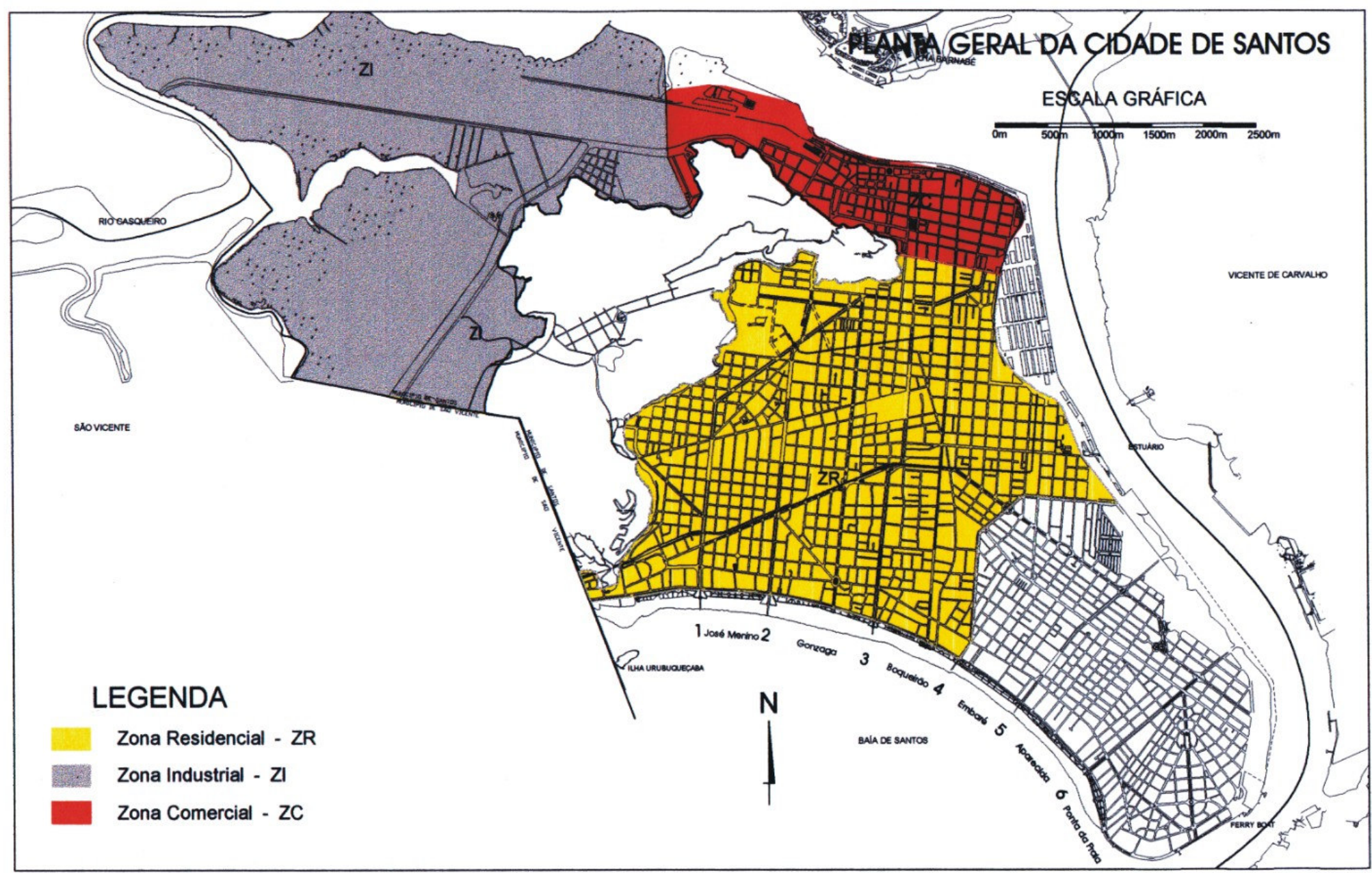

1922

Código de Construções do Município Lei $n^{\circ} 675$ de 28 de junho de 1922 


\subsubsection{A legislação urbanística em Santos no Período Desenvolvimentista}

\subsubsection{A Legislação urbanística até o segundo pós- guerra}

Em 1926, a Lei $N^{\circ} 803$, de 31 de dezembro, veio a alterar os perímetros da cidade definidos pelo Código de 1922 e trazer novas disposições para a construção dos chalés de madeira, então uma preocupação crescente para os legisladores. O perímetro urbano teve seus limites alterados ao sul, incorporando novas áreas que correspondiam aos atuais bairros da Encruzilhada, Jabaquara e parte da Vila Mathias e, também aos do Marapé, José Menino, Pompéia, Gonzaga, Boqueirão, parte de Aparecida e Ponta da Praia, com exceção das vias de trânsito mais local.

O perímetro suburbano passou a abranger também os morros do Monte Serrat e Cutupé, e a área entre a praia e a linha da Southern São Paulo Railway - denominada posteriormente de E. F. Sorocabana, depois FEPASA e atualmente CPTM. Atingiu também 0 Jabaquara, o Gonzaga, o Macuco, Estuário, Embaré, Boqueirão e a Villa Balneária em Guarujá. O perímetro de transição passou a compreender a atual Zona Noroeste, entre o rio Saboó e o Matadouro Municipal, abrangendo os bairros Alemoa, Saboó e Chico de Paula, bem como parte do Marapé, Campo Grande, Ponta da Praia - na Zona Leste - e as vertentes dos morros do São Bento, Fontana, Cutupé e Nova Cintra, até " $50 \mathrm{~m}$ para cima".

Esta lei manteve a permissão para construção de chalés fora do perímetro urbano, e alterou os demais pré-requisitos para construção já previstos anteriormente pela Lei $\mathrm{N}^{\circ} 460$, de 26 de abril de 1911. De fato, os chalés remanescentes ainda podem ser encontrados hoje nos morros e nas vias mais locais, onde o mercado imobiliário não implementou o processo de verticalização na Zona Leste da cidade.

A respeito desta lei, pode-se ler em ANDRADE (1989: 216): "Foi só em 1926 que houve uma lei específica sobre construção de 'chalés' de madeira. (...) Usa a palavra 'chalet' ainda em francês, mas já com o sentido popular da casa de gente pobre. Sobre a expedição das cartas de habitação foi feita outra lei, no ano seguinte, que estipulava multa para a sua falta, mas que podia ser dispensada no caso de pessoas pobres, que não tivessem mais de um 'chalet' para sua habitação". Mais adiante, ANDRADE citou o Decreto $N^{\circ} 68$, de 1932, assinado pelo Prefeito Aristides Bastos Machado, que possibilitava a legalização dos chalés clandestinos, desde que fora do perímetro urbano.

As principais alterações introduzidas pela Lei $N^{\circ} 803$ ocorreram nas áreas mínimas exigidas por compartimento, da seguinte forma: os dormitórios deveriam possuir $9 \mathrm{~m}^{2}$, ao invés de $12 \mathrm{~m}^{2}$; a cozinha $6 \mathrm{~m}^{2}$, ao invés de $7 \mathrm{~m}^{2}$; a sala 12 $\mathrm{m}^{2}$, ao invés de $16 \mathrm{~m}^{2}$; e o banheiro $4 \mathrm{~m}^{2}$, ao invés de $3 \mathrm{~m}^{2}$. Com a redução das áreas mínimas, a Prefeitura permitiu o barateamento do custo de construção dos chalés, ao menos oficialmente.

No entanto, chamou-nos a atenção o disposto no artigo 17 , que previa a assinatura pelo proprietário do chalé de um "termo de precariedade", pelo qual este se obrigava a demoli-lo assim que a Prefeitura o exigisse. Porém, essa demolição só poderia ocorrer cinco anos contados da data da licença da construção. Tudo indica que os legisladores da época consideravam o chalé uma modalidade de 
moradia provisória. O que se viu, foi sua generalização pelas áreas onde foi permitido edificar e ainda hoje alguns deles podem ser encontrados nos bairros da Zona Leste e morros de Santos. Contudo, foi a valorização imobiliária desses bairros, a partir da possibilidade de adensamento dos lotes nos mesmos, a verdadeira responsável pela quase extinção dos chalés em Santos.

Outra novidade, foi a introdução, pelo artigo 36 , de um repertório de três tipos de casas de madeira, cujo projeto poderia ser fornecido pela Prefeitura, gratuitamente, conforme o perímetro em que a construção fosse realizada. Mais adiante, pelo artigo 38, a Prefeitura ganhou a prerrogativa de legalizar as construções clandestinas, desde que não prejudicassem "a saúde e higiene públicas". $\mathrm{Na}$ verdade, esse tipo de anistia ocorre até hoje, com várias alterações em seu conteúdo e abrangência. A larga utilização desse expediente, sobretudo em períodos préeleitorais, fez com que a legalização de obras clandestinas se transformasse no paradigma da política urbana populista e clientelista em Santos.

Sobre a Lei $N^{\circ} 803$, de 1926, CALDATTO (1998: 121) afirmou que "A administração pública empregava ações diferenciadas para os imóveis situados nas áreas de expansão urbana, como formas de negociar com os diversos interesses em questão. Se de um lado os chalés não seriam mais ameaçados de demolição, por outro, os agentes imobiliários mantinham suas esperanças em remove-los na medida em que sua tolerância ainda era tida como provisória". É interessante ler em CALDATTO, ainda, a reprodução dos pareceres das comissões permanentes da Câmara Municipal, atinentes ao tema.
Claramente havia posições contraditórias. Por um lado, o setor da promoção imobiliária pressionava pela erradicação dos chalés. Por outro, a Prefeitura sabia que sua eliminação causaria um problema social de grandes proporções. Foi nesse caldo de cultura que se aprovou a Lei $\mathrm{N}^{\circ} 803$, fixando-se limites territoriais para a construção dos chalés. A delimitação de territórios de exclusão, afirmava-se como a solução padrão para a consolidação da intensão de afastar a população de baixa renda das áreas mais valorizadas da cidade.

Também em CALDATTO (1998: 122), verifica-se que a aprovação dessa lei trazia outro fator de interesse para a municipalidade. A possibilidade de legalização de chalés "clandestinos" era vista como "de interesse para os cofres públicos, beneficiando-se da possibilidade de aumentar a receita com a cobrança de impostos, ao mesmo tempo em que coibia ações corruptas dos fiscais de obra".

Em 1927, a Lei $\mathrm{N}^{\circ} 825$, de 26 de novembro, citada em ANDRADE (1989: 216), viria promover alterações na Lei $\mathrm{N}^{\circ}$ 803, permitindo a legalização dos chalés existentes a partir da vigência dessa lei. No entanto mantinha-se o caráter precário dessas construções e a possibilidade de demolição sem indenização por razões de "ordem pública, como necessidade, utilidade, higiene ou embelezamento".

Essa mesma lei alterou novamente o perímetro urbano, fundindo-o ao suburbano. O perímetro de transição, por sua vez foi ampliado incorporando parte de Cubatão, ao longo da avenida Bandeirantes, que liga Santos àquele município.

A respeito destas leis, CALDATTO (1998: 127) afirmou: "Todas essas medidas surtiram pouco efeito. Diversos 
chalés continuaram sendo construídos clandestinamente, sem obedecer às leis vigentes. Nos anos seguintes, a Prefeitura realizou novas investidas no controle das construções de madeira. Porém, as circunstâncias históricas que afetaram a economia do país acabaram por frustrar mais essa tentativa".

A Lei $N^{\circ} 826$, de 16 de dezembro de 1927, por razões sanitárias, estabelecia emenda ao zoneamento em vigor, proibindo a construção de "oficinas, armazéns e habitações coletivas" nas proximidades do Hospital de Isolamento, no bairro do Boqueirão.

Mais tarde, em 1929, visando completar a tarefa de transformar Santos em uma cidade moderna, totalmente urbanizada e que nada lembrasse a cidade das epidemias, a Lei $\mathrm{N}^{\circ} 852$, de 27 de maio de 1929, visava obrigar a todos os proprietários de terrenos nas áreas urbanas e suburbanas a aterrá-los de modo a esgotar as águas pluviais, elevando a multa estabelecida pelo Código de Construções para $100 \$ 000$.

Após a chegada de Getúlio Vargas ao poder da república, a legislação urbanística de Santos ainda manteve, por muito tempo, as diretrizes de embelezamento e higienização da cidade, típicas do final do século XIX e primeiras décadas do século XX. Porém, pouco a pouco a legislação direcionou-se para a formação de uma cidade capitalista moderna, da era industrial. O funcionalismo passou a ser a regra. A cidade deveria ser entendida como uma "fábrica", em que seus distintos espaços deveriam cumprir, com eficácia, suas diferentes funções permitindo a produção de um espaço urbano cada vez mais orientado pelos interesses do grande empreendedor imobiliário e menos pela questão sanitária.

As leis que se seguiram, desde então, só fizeram aprofundar e detalhar o instituto do zoneamento de uso e ocupação. Esse período teve seu apogeu, em termos de legislação urbanística, com a sanção do Novo Código de Obras do Município, Decreto-Lei $N^{\circ} 403$, de 15 de setembro de 1945 e posteriormente com o Plano Regulador da Expansão e Desenvolvimento da Cidade, Lei N ${ }^{\circ} 1.316$, de 27 de dezembro de 1951, elaborado por equipe coordenada pelo urbanista Francisco Prestes Maia.

Em 9 de maio de 1.956, promulgou-se a modificação do Decreto-Lei dada pela Lei $N^{\circ} 1.831$ e, já sob a ditadura militar, encerrou-se o ciclo com a promulgação de um conjunto de leis formado pelo Plano Diretor Físico do Município, Lei No 3.529, de 16 de abril de 1968 e suas posteriores alterações, sobretudo com o novo zoneamento dado pela lei $\mathrm{N}^{\circ} 209$, de 27 de novembro de 1986; pelo Código de Edificações do Município, Lei º3.530, de 16 de abril de 1968; pelo novo Código de Posturas do Município, Lei $\mathrm{N}^{\circ}$ 3.531, de 16 de abril de 1968, as Normas Ordenadoras e Disciplinadoras da Urbanização e da Preservação da Paisagem Natural dos Morros de Santos, Lei $\mathrm{N}^{\circ}$ 3.533, de 16 de abril de 1968; e, na década seguinte, pelo Código Tributário do Município ${ }^{84}$, Lei $N^{\circ} 3.750$, de 20 de dezembro de 1971 e pelo Código de Uso e Proteção dos

84 Embora o Código Tributário não seja propriamente uma lei urbanística, e não vá ser objeto de aprofundamento no presente trabalho, é importante citá-lo, pois o mesmo trata dos critérios de lançamento do IPTU, influindo diretamente na dinâmica das transações imobiliárias na cidade. 
Recursos Naturais do Distrito de Bertioga, Lei $N^{\circ} 4.078$, de 3 de dezembro de 1976 (ver Tabela 16).

Nesse período, foram vários os exemplos de legislação que mantinha a diretriz de embelezamento da cidade, como em 1940, o Decreto $N^{\circ} 254$, de 2 de março, pelo qual a Prefeitura instituia um prêmio anual a ser conferido aos responsáveis pela construção de edifícios, devido ao aspecto estético, condições de higiene e contribuição ao embelezamento urbano. O prêmio era previsto para três categorias: "residenciais individuais, residenciais populares ou operárias e edifícios comerciais".

No mesmo ano, o Decreto-Lei $\mathrm{N}^{\circ} 258$, de 2 de abril, redefinia os perímetros urbano e rural da cidade, criando a figura das "Zonas Urbanas e Suburbanas". Na verdade, o antigo perímetro urbano foi ampliado, com parte do morro da Nova Cintra e avançando mais em direção à Ponta da Praia. Ao mesmo tempo, o antigo perímetro tornou-se Zona Urbana e o perímetro de transição transforma-se em Zona Suburbana. O decreto criou, também, as Zonas Urbanas e Suburbanas de Cubatão. A extensão do perímetro em direção ás praias, mais do que uma simples adaptação à legislação estadual, como poderia vir a ser interpretada, foi uma exigência ditada pela ampliação da ocupação do território da cidade rumo à orla, nos morros e rumo à Cubatão - passagem para o planalto.

O Decreto-Lei $\mathrm{N}^{\circ}$ 306, de 25 de março de 1941, estabeleceu novo zoneamento residencial, constituído por três zonas. A primeira zona compreendia, aproximadamente os bairros do José Menino, Gonzaga e Boqueirão, lado oeste da avenida Conselheiro Nébias. A segunda, dividida em quatro seções, compreendia, aproximadamente parte dos bairros do Marapé, Campo Grande, Vila Mathias e Macuco. A terceira era dividida em três seções e correspondia a partes do Marapé, Embaré, Estuário e morros. Assim, as zonas residenciais foram mais detalhadas, visando criar bolsões dentro da grande área de uso misto que predominava na cidade. Foi, também, a primeira vez na legislação edilícia santista, que se admitia o uso residencial nos morros de Santos, ainda que sem detalhar critérios de ocupação.

Esse mesmo decreto criou de forma mais explícita ainda a figura da taxa de ocupação do lote, até então disciplinada de forma indireta. A taxa era de $75 \%$ da área total do lote e com recuo frontal de $5 \mathrm{~m}$, nas Zonas Residenciais. Os lotes de esquina nessas zonas tiveram a taxa de ocupação acrescida em 10\%. Admitia-se, também, a construção de dois prédios conjugados, desde que formassem um conjunto harmônico (grifo do autor).

Em 1942, pelo Decreto-Lei $N^{\circ} 343$, de 14 de agosto de 1942, o Prefeito Gomide Ribeiro dos Santos criou as comissões Técnica e Consultiva do Plano Regulador da Cidade, a primeira um órgão de planejamento, inédito na administração, foi formado por funcionários da Prefeitura e contratados, e seria dirigido por "um urbanista de renome nacional" a critério do prefeito.

Com efeito, a Comissão Técnica passou a ser coordenada pelo urbanista Prestes Maia, que dirigiu seus trabalhos até a aprovação definitiva do plano, em 1951. A Comissão Consultiva era um conselho de diretores e chefes de divisão de várias áreas da Prefeitura, que deveriam opinar e aprovar as propostas formuladas pela primeira. $\mathrm{O}$ objetivo era a elaboração de um plano que acabou se tornando, em 
sua maior parte, uma lei de diretrizes viárias e embelezamento, bem ao estilo do que se produzia em outras metrópoles brasileiras, como o Plano Agache, no Rio de Janeiro.

\subsubsection{A legislação urbanística até o golpe militar}

Em 1945, O Decreto-Lei $N^{\circ} 403$, de 15 de setembro, estabeleceu o novo Código de Obras do Município, ampliando definitivamente o instituto do zoneamento de usos e ocupação (ver Mapa à p. 136). Mais que isto, como novidade, esse código apresentou regras gerais para parcelamento do solo, coisa que a legislação anterior tratava de forma bastante incompleta. Na verdade, essa lei não se restringiu, apenas, a obras particulares e atuava mesmo fornecendo diretrizes para obras públicas. O novo código era um compêndio constituído por 693 artigos, divididos em 25 títulos que dispunham sobre: zoneamento; habilitação de profissionais; licenciamento de obras; dimensões dos lotes e alinhamento; iluminação e ventilação; compartimentos; aproveitamento dos lotes; estética dos edifícios; arborização e implementos urbanos tais como bancas de jornal, denominados empachamento -; materiais de construção e instalações prediais; construções especiais - teatros, escolas, hotéis, cinemas, etc. -; loteamentos; cálculo estrutural; vias públicas; instalações mecânicas - elevadores, monta-cargas, etc. -, autuações e outros. É importante destacar, dentre as inovações, que o Capítulo Segundo, do Título XIV, tratava de "Habitações do Tipo Econômico".

O novo zoneamento detalhava um pouco mais as zonas criadas pelo Código de 1922, incorporando as novas zonas residenciais introduzidas pelo Decreto-Lei $N^{\circ} 306$, de 25 de março de 1941. O perímetro rural foi definitivamente incorporado como Zona Rural ou Agrícola. Eram estas as zonas: Zona Comercial Central - ZCC, Zona Comercial Secundária - ZCS, 1a Zona Residencial - ZR1, 2 ${ }^{\text {a }}$ Zona Residencial - ZR2, 3므 Zona Residencial - ZR3, Zona Portuária - ZP, Zona Industrial - ZI e Zona Rural ou Agrícola - ZA.

A ZCC correspondia ao centro da cidade, ou seja, seu núcleo colonial, agora remodelado. A ela eram destinados os "estabelecimentos comerciais, escritórios, consultórios, bancos, sedes de companhias ou empresas, laboratórios, restaurantes, confeitarias, hotéis, habitações, casas de diversões, tipografias, cafés e similares". A "juízo da Prefeitura" poderiam ser construídas indústrias leves. Os imóveis deveriam ser construídos no alinhamento e suas alturas limitadas por uma fórmula - introduzida pela lei com a denominação de "gabarito" - que as vinculavam à largura dos logradouros, limitando-as a $40 \mathrm{~m}$. No entanto, os edifícios não poderiam ter menos de três pavimentos, no alinhamento.

A ZCS compreendia partes do Centro, em suas extremidades e os bairros periféricos a este: Valongo, Paquetá, Vila Nova, sopé do Monte Serrat e parte da Vila Mathias. Nesta zona eram admitidos: "garagens, postos de abastecimento de automóveis e depósitos de materiais e mercadorias". Quanto a altura das edificações, utilizava-se o mesmo gabarito admitido pela ZCC, e os edifícios deveriam ter pelo menos dois pavimentos no alinhamento. A "juízo da Prefeitura" admitiam-se edificações de um pavimento e recuadas do alinhamento, desde que não mais que $4 \mathrm{~m}$. 
As três zonas residenciais eram descontínuas e divididas em seções, ou subzonas. A ZR1 abrangia parte do Boqueirão, o Gonzaga e o José Menino, além dos eixos das avenidas Conselheiro Nébias, Ana Costa e Canal 3, até os limites da ZCR. A ZR2, subdividida em 4 seções: a $1^{\text {a }}$ incorporava parte do Marapé, Vila Mathias, o Campo Grande e Vila Belmiro; a $2^{\underline{a}}$ incorporava o Jabaquara e parte do Marapé; a 3a era uma estreita faixa entre o Canal 3 e a rua Brás Cubas, na Vila Mathias e a 4⿳亠丷a , mais extensa, incorporou a Ponta da Praia, Aparecida, Embaré, e partes do Boqueirão, Macuco, Vila Mathias e Vila Nova, junto ao Porto. A ZR3 era subdividida em 3 seções: a $1^{\text {a }}$ compreendia o bairro do Estuário e pequena parte do Macuco; a $2^{\underline{a}}$ parte do Marapé e a $3^{\underline{a}}$ os morros da cidade.

Nessas zonas, com algumas diferenciações entre elas, eram privilegiadas as habitações, admitindo-se comércios de caráter "local", desde que inseridos em uma testada de quadra em que já houvesse mais de $50 \%$ da extensão ocupada por essas atividades. Previa-se, ainda, a criação por decreto, de núcleos comerciais em eixos viários, expediente consolidado na legislação posterior, e mantido, sob outra forma, até o presente. Na ZR1, "a juízo da Prefeitura", poderiam ser construídos hotéis, estúdios, termas, casas de diversão, estabelecimentos de ensino, teatros, casas de saúde, hospitais, indústrias leves, garagens comerciais e outras atividades similares. Nessa zona a taxa de ocupação seria de $65 \%$ da área do lote e os recuos $5 \mathrm{~m}$, de frente e 1,5 m laterais.

Nota-se que nas zonas centrais não se estabelecia taxa de ocupação, podendo haver impermeabilização total do lote. Quanto à altura, a ZR1 limitava os edifícios a 4 pavimentos, exceto nas avenidas da praia - então já urbanizadas - e praça da Independência - no centro do Gonzaga -, onde estes poderiam chegar a $10 \mathrm{~m}$. O recuo frontal exigido era o mesmo da legislação anterior, variando conforme a importância do logradouro. No entanto, poderia ser admitida altura maior, desde que os recuos laterais aumentassem 2 $\mathrm{m}$, a cada pavimento acrescentado ao número máximo de pavimentos. Na ZR2 e ZR3, os usos permitidos eram os mesmos para a ZR1 e a altura dos edifícios não poderia exceder a $18 \mathrm{~m}$. Os recuos também variavam um pouco.

É importante perceber que, por meio do controle da altura das edificações, consolidou-se o adensamento da área central da cidade, mas também foi incentivada a formação de um novo centro de comércio e serviços, mais próximo das áreas ocupadas pela burguesia, o Gonzaga.

Porém, um ponto importante, para a finalidade de nosso estudo, é que na ZR3, áreas intermediárias da Zona Leste, entre os bairros da orla e o Centro, seriam admitidos "a juízo da Prefeitura" armazéns, depósitos, cocheiras e estábulos. Da mesma forma, seriam admitidas as "casas de tipo econômico", ou seja, enquanto nas áreas mais "nobres" da cidade, ocupadas pela burguesia, segregavam-se os usos, afastando-se os que causavam mais desconforto, às classes populares era destinado oficialmente um território onde estas tinham que conviver com os impactos advindos do uso misto.

A ZP, outra novidade da lei, consistia na faixa portuária existente então ${ }^{85}$. Este era, certamente, um grande avanço

\footnotetext{
${ }^{85} \mathrm{O}$ atual corredor de exportação, no Estuário e Ponta da Praia, bem como os terminais da Alemoa ainda não haviam sido construídos, por meio de grandes aterros e molhes.
} 
na forma de compreender a cidade, pois, anteriormente, essas áreas eram excluídas, por serem de competência da Companhia Docas de Santos, como se não fizessem parte de Santos. Nessa zona seriam permitidos, além dos usos típicos da atividade portuária, fábricas, laboratórios, estabelecimentos de ensino, habitações e similares. Dessa forma, tolerou-se a convivência de usos bastante conflitantes - porto e habitação - que, com a implantação do Corredor de Exportação - na década de 1970 - nos bairros do Macuco, Estuário e Ponta da Praia, tornou-se um grave problema urbano.

Isto ocorreu, pois esses bairros junto à faixa do porto, eram habitados por classes de renda mais baixa, geralmente formadas por operários e trabalhadores portuários, que passaram a conviver na mesma área com empresas vinculadas ao porto, geralmente transportadoras, oficinas de reparos navais e pátios de cargas.

Mais adiante, estabeleceu-se que a altura máxima a ser admitida para os edifícios construídos na ZP seria a mesma da ZCS, ou seja, sem limite mínimo de pavimentos.

A Zl compreendia parte da Zona Noroeste, a partir do rio Saboó, excluindo-se áreas alagadiças, delimitadas por uma linha imaginária, paralela distante $100 \mathrm{~m}$ a oeste da estrada de ligação entre Santos e São Vicente - atual avenida Nossa Senhora de Fátima - hoje correspondente à maior parte dos bairros Areia Branca, Santa Maria e Castelo, acrescida dos bairros Chico de Paula, Rádio Clube e Bom Retiro, inteiros, bem como pequena parte da Alemoa, ao sul da estrada dos Bandeirantes, o que coincidia com parte do perímetro suburbano. Seria uma área destinada a fábricas, em geral, estabelecimentos de ensino, grandes oficinas, depósitos e similares. A altura máxima admitida para os edifícios era de 5 pavimentos ou $17,80 \mathrm{~m}$, com ocupação máxima do lote de $80 \%$. Seria tolerada a construção de habitações, comércio local, escritórios, laboratórios e similares, desde que a taxa de ocupação dos lotes não ultrapassasse os $65 \%$ de suas áreas. $\mathrm{Na}$ verdade, sobretudo a partir da década de 50 , essa zona - em sua parte ao sul da Via Anchieta - mais os morros e a área contígua, já no município de São Vicente, tornaram-se as áreas residenciais, por excelência, das classes de menor renda, incapacitadas de acessar moradias na Zona Leste da cidade de Santos.

A ZA era a mesma delimitada pelo Decreto-Lei $N^{\circ} 258$, de 2 de abril de 1940. Nela, era previsto o uso agrícola e habitacional, tolerando-se, "a juízo da Prefeitura", indústrias pesadas, depósitos de inflamáveis e explosivos, não podendo a ocupação das glebas ultrapassar $60 \%$ de sua área. Consolidava-se, assim, a tendência a segregar do tecido urbano os usos mais perigosos, coisa que não ocorreu inteiramente, pois a Prefeitura nunca logrou controlar as atividades na área portuária, e diversos depósitos de granéis líquidos, do setor petroquímico, estabeleceram-se junto à cidade, como veio a ocorrer no bairro da Alemoa.

Entretanto, uma das principais novidades introduzidas pelo Código de 1945 foi em relação ao parcelamento do solo. Até então, o processo de loteamento era menos regulamentado e dispositivos importantes, como dimensões de quadras e lotes não tinham limitações claras. A partir de 1945 só seriam admitidos os lotes de loteamentos aprovados. Porém, a pressão do modelo de urbanização periférica era evidente e o artigo 104 previa a legalização de 
lotes, a "título precário", para áreas onde não houvesse arruamento aprovado. $\mathrm{Na}$ verdade, a partir dessa lei, os dispositivos e exigências para se aprovar um loteamento, culminando com a Lei Federal $N^{\circ} 6.766$, de 1979, foram crescendo de tal monta que os loteamentos irregulares passaram a ser a regra, e não mais a exceção, não só em Santos, como nos demais municípios centrais da Baixada Santista.

A grande inovação, porém, foi o estabelecimento, pelo artigo 569, de dimensões mínimas para os lotes e conforme a zona em que o loteamento viesse a ser implantado. Para a ZR1, a testada mínima de lote admitida era de $12 \mathrm{~m}$ e sua área não poderia ser menor que $300 \mathrm{~m}^{2}$. Nas demais zonas, a testada mínima era de $10 \mathrm{~m}$ e a área mínima de $250 \mathrm{~m}^{2}$, exceto na ZR3, nos núcleos de comércio local e nos núcleos de "casas de tipo econômico" onde essas dimensões seriam, respectivamente, $8 \mathrm{~m}$ e $200 \mathrm{~m}^{2}$. Na Zona Rural a testada não deveria ser inferior a $15 \mathrm{~m}$ e a área $450 \mathrm{~m}^{2}$

Nota-se que, mesmo rebaixando-se as exigências para moradias ditas econômicas, de 300 para $200 \mathrm{~m}^{2}$, essas dimensões já eram, para o mercado imobiliário da Zona Leste, naquela época, proibitivas para as classes de menor renda. Além disso, esses núcleos dispunham de uma área muito limitada, dentro da ZR3 na zona leste, fatores esses que vieram a "empurrar", mais e mais, a população de baixa renda para os morros - também uma ZR3 - e periferias dessa região da cidade. Como se vê, à medida que Santos foi crescendo, a legislação restringiu, ainda que de forma indireta, o acesso às áreas privilegiadas para a população de menor renda.
Para estas classes populares o novo código previa três alternativas. A primeira, a "casa do tipo econômico" era regulamentada pelo artigo 357, muito extenso, que limitava essas moradias a um "único pavimento de área não superior a $80 \mathrm{~m}^{2}$ " e que fizesse parte de loteamento aprovado. Estabelecia-se recuo frontal de $5 \mathrm{~m}$ e lateral de 1,5 m para esse tipo de habitação. O material admitido seria a alvenaria de tijolo, ainda que com menores exigências em relação às demais edificações. As dimensões mínimas permitidas dos cômodos seriam: $8 \mathrm{~m}^{2}$ para salas e quartos, $4 \mathrm{~m}^{2}$ para cozinhas e $1,50 \mathrm{~m}^{2}$ para banheiro com chuveiro e $1,20 \mathrm{~m}^{2}$, se só possuíssem "WC"86. Como podemos observar, houve significativa redução em relação às exigências de áreas mínimas dos cômodos, em relação à legislação anterior, específica para os chalés de madeira.

A segunda modalidade era o próprio chalé de madeira, então classificado como "construção expedita", e regulamentada pelo Capítulo III, em sua Seção I, nos artigos de 306 a 311. O chalé só seria admitido na Zona Rural e nos morros - ZR3 -. Os já existentes em outras zonas, antes da data da promulgação desta lei, só poderiam ser caiados. Reformas e ampliações não seriam mais admitidas, como forma de banir tais edificações das áreas consideradas "nobres" da cidade, com exceção das zonas onde se admitia casa de tipo econômico. Na ZR2, onde

\footnotetext{
86 É interessante comparar essas dimensões com as exigidas para os chalés de madeira pelas leis $\mathrm{N}^{\circ} 460$, de 26 de abril de 1911 e $\mathrm{N}^{\circ} 803$ de 31 de dezembro de 1926, respectivamente: dormitórios com $12 \mathrm{~m}^{2}$ para a primeira e de $9 \mathrm{~m}^{2}$ para a segunda; cozinhas com $7 \mathrm{~m}^{2}$ e $6 \mathrm{~m}^{2}$

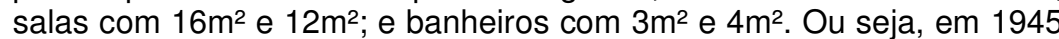
reduziram-se as exigências para as moradias econômicas, em relação ao que se estabelecia, anteriormente, como dimensões mínimas para os chalés.
} 
existiam chalés, passou-se a admitir a construção de casas de tipo econômico. No entanto, os chalés clandestinos nas zonas comerciais e na ZC1 poderiam ser legalizados. Porém, como em todas as demais localizações, da mesma forma que na legislação anterior, a legalização seria sempre a "título precário", mantendo o caráter provisório que se atribuía a essas moradias.

Para os chalés estabeleceu-se que tivessem um único pavimento, com $4 \mathrm{~m}$ de afastamento de outras construções de madeira, e como áreas mínimas dos "compartimentos de permanência prolongada" - salas - $8 \mathrm{~m}^{2}$. Curiosamente, essa lei não estabeleceu as áreas mínimas exigidas para outros tipos de compartimento dos chalés. No restante das edificações, adotou-se um padrão já sensivelmente menos exigente que no início do século. Seriam admitidas como áreas mínimas dos "compartimentos de permanência prolongada" $8 \mathrm{~m}^{2}$, dos "compartimentos de permanência noturna" - dormitórios - $10 \mathrm{~m}^{2}$ para casas e $12 \mathrm{~m}^{2}$ para apartamentos, das cozinhas $7 \mathrm{~m}^{2}$, das copas $4 \mathrm{~m}^{2}$ e dos banheiros $1,50 \mathrm{~m}^{2}$, quando dentro da habitação e $1,20 \mathrm{~m}^{2}$ quando em quintais.

Ou seja, a legislação aproximava, pouco a pouco, as dimensões mínimas exigidas para os compartimentos de habitações populares em relação aos das habitações produzidas para a burguesia. Mesmo assim, não houve queda substancial no diferencial do preço global, entre um e outro tipo de unidade, o que seria agravado pela conjuntura macro-econômica, em especial pela falta de incentivo à produção rentista e pela generalização da ideologia da casa própria, típica do período, como apontou BONDUKI (1998).
A Prefeitura dispunha, ainda, de três plantas típicas de "casa econômica" para quem pudesse pagar uma "taxa módica arbitrada pelo Prefeito". Eram estas as dos tipos A, $\mathrm{B}$ e $\mathrm{C}$, que variavam entre 1 e 2 dormitórios. Para esses casos dispensava-se a exigência de profissional responsável registrado e não se tolerava a concessão de mais de uma licença por pessoa. A Prefeitura aprovava previamente o preço dessas moradias, suas condições de financiamento, limitando os juros a $8 \%$, procurando controlar esse mercado. A locação não seria admitida, salvo em casos "devidamente justificados", fator que pode ser atribuído à crescente penetração da ideologia da casa própria neste período.

Essa modalidade de moradia seria um avanço, se compararmos com a forma oficial de tratar a questão da habitação popular no princípio do século XX. Mas foi insuficiente para dar conta da falta de condições econômicas para 0 acesso das classes populares às habitações na Zona Leste de Santos, uma vez que os terrenos tinham valorização crescente nessa área.

A terceira modalidade de moradia popular prevista era a "vila", ou seja, conjunto de edificações conjugadas, popularmente denominadas "casas geminadas", que foram as moradias típicas da classe média de menor renda e, em menor medida, das classes populares. Estas foram regulamentadas na Seção II, do Título X, pelos artigos 179 a 192. A Prefeitura poderia "tolerar" a existência das vilas já construídas, mas a partir de então só seriam admitidas as vilas em fundo de terrenos onde não fosse possível abertura de vias, ou quando isso fosse possível, à conveniência da Prefeitura, estas poderiam ser construídas desde que não o fossem nas zonas comerciais, na ZR1, 
nos largos e praças. A testada mínima das vilas não poderia ser inferior a $6 \mathrm{~m}$ e, em casos especiais, $3 \mathrm{~m}$. A taxa de ocupação para os lotes interiores à vila poderia exceder em $10 \%$ a taxa para a zona em que a mesma fosse construída. As dimensões dos cômodos seriam as mesmas admitidas para as zonas em que essas vilas estivessem inseridas, ou seja, excessivas para que estas se configurassem em alternativa de moradia verdadeiramente popular.

Para finalizar, é interessante ressaltar que esse código manteve quase intactos os mesmos dispositivos relativos à estética das construções da legislação anterior, uma vez que a questão do embelezamento da cidade ainda era uma questão recorrente para os legisladores no período. Além disso, o Código aprofundou e detalhou normas sobre implementos urbanos, como quiosques, bancas de jornal, mobiliário em geral, letreiros e propaganda no espaço público, revelando grande preocupação dos legisladores com a estética urbana. 


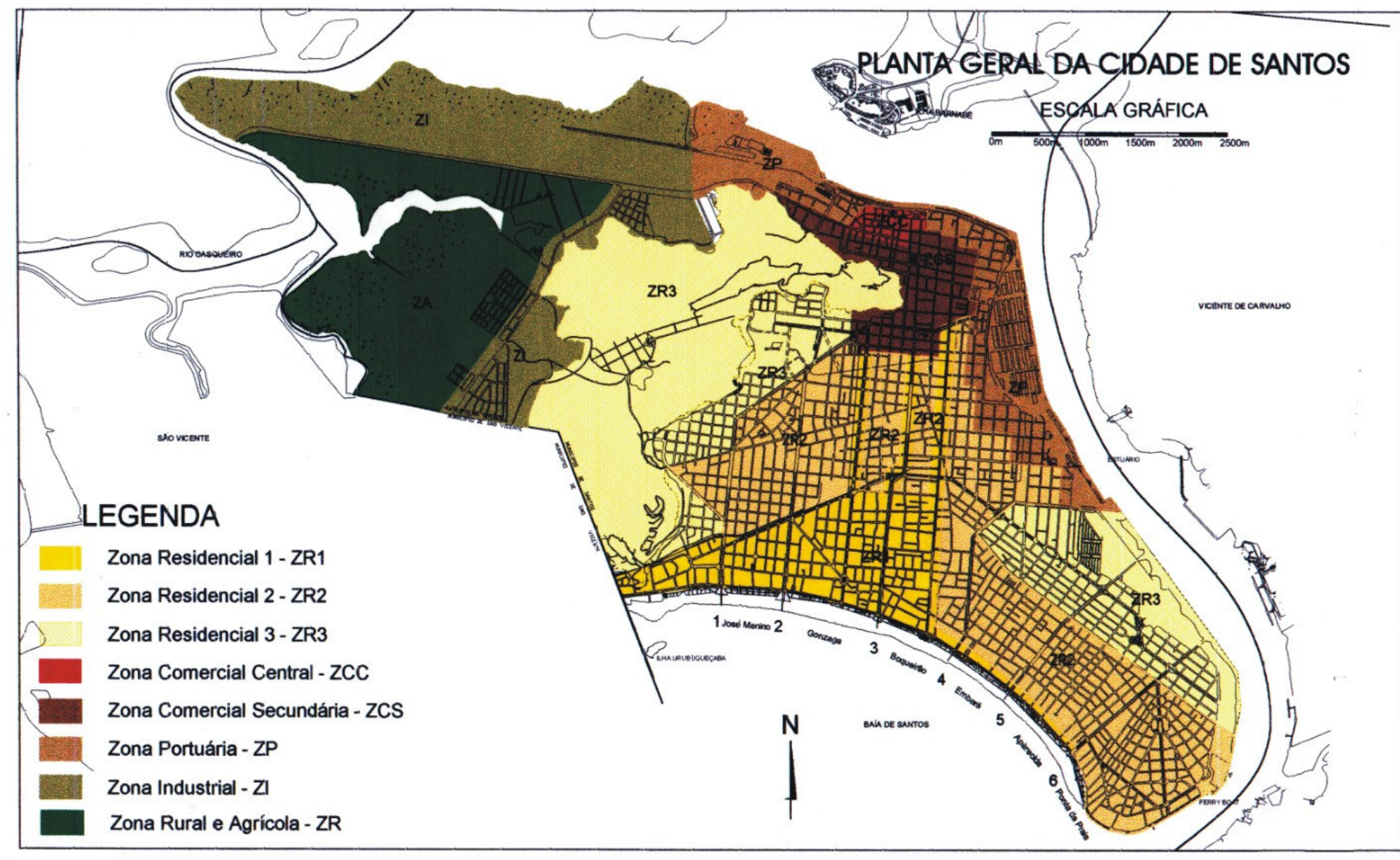

1945

Zoneamento Aprovado pelo Decreto-Lei $\mathrm{n}^{\circ} 403$ de 15 de setembro de 1945.

Fontes : MARTINS, Ana Maria Sala Minucci. "O Porto de Santos na legislaçăo e propostas de planejamento SANTOS. Maril 1945 a 1995 ". Dissertaçáo de Mestrado apresentada à FAU-USP Såo Paulo, 2000 tado à FAU Santos - Santos , 1986. Descriçăo no caderno de publicaçåo do próprio Decreto-Lei 
Pelo Decreto Executivo $N^{\circ} 238$, de 18 de junho de 1947, foram criados Núcleos Comerciais nas principais vias das Zonas Residenciais, provavelmente atendendo a pressões para que se permitisse maior flexibilização da segregação de usos nessas áreas, admitindo-se atividades supostamente compatíveis com o uso residencial. Esses núcleos foram consolidados em 1956, na revisão do Código de 1945 , pela Lei $N^{\circ} 1.831$ e permanecem na legislação de uso do solo até o presente, sob outra forma e de maneira ampliada, fixando a vinculação entre comércio e hierarquia do sistema viário nas zonas onde predomina o uso residencial.

Em 1948, pela Lei $N^{\circ}$ 940, de 29 de março, a Prefeitura fixou prazo de três meses para submeter à apreciação da Câmara o Plano de Expansão e Melhoramento da Cidade, ficando "suspensas todas as obras e projetos que contrariarem disposições contidas nos planos de urbanização que servirão de base ao estudo (...)". Dessa forma, entrava em fase final a elaboração do Plano Regulador, coordenado por Prestes Maia.

Com o crescimento de Santos, nas décadas anteriores, vários eixos viários projetados por Saturnino e as ruas no núcleo colonial da cidade não cumpriam mais as funções exigidas por uma cidade da era industrial. $O$ crescente fluxo pendular cidade-orla começava a incomodar a burguesia que reclamava melhores acessos às áreas de trabalho e prestação de serviços. Da mesma forma, as funções portuárias vinham sendo prejudicadas por estrangulamentos na malha viária da cidade. Assim, era preciso um plano de avenidas e embelezamento da cidade, que a preparasse para o futuro.
No mesmo ano, pela Lei $\mathrm{N}^{\circ} 942$, de $1^{\circ}$ de abril, a Prefeitura autorizou a instalação de energia elétrica, "a título precário, em todas as casas de madeira". A concessionária do "serviço de iluminação" da cidade poderia, assim, fazer as ligações elétricas dos chalés, desde que esses fossem habitados por seus proprietários. Essas ligações anteriormente eram dificultadas, como forma de controlar a proliferação das casas de madeira. Provavelmente, a essa altura, já se considerava irreversível o fato da população de baixa renda não ter outra alternativa de habitação mais concreta, levando o governo municipal a relaxar suas restrições.

A Lei $N^{\circ} 977$, de 2 de setembro de 1948, alterava os recuos para os Núcleos Comerciais criados pelo Decreto Executivo $N^{\circ} 238$, de 1947, adotando os recuos estabelecidos pelo Código de 1945, para as Zonas Residenciais, os quais eram mais significativos.

Mais tarde, em 1950, a Lei $\mathrm{N}^{\circ} 1.111$ de 21 de junho, alterada logo em seguida pela Lei $\mathrm{N}^{\circ} 1.163$, de 12 de dezembro do mesmo ano, estabelecia o recuo de fundo de lote e a obrigatoriedade de existirem vagas para automóveis em edifícios de apartamento, por certo uma exigência advinda da expectativa de incremento da verticalização da orla marítima, provocada pelo crescimento do turismo balneário. Em sua alteração foi exigida a proporção de 1/3 de vagas do total de apartamentos. Essa exigência, embora pertinente, em função do impacto que o crescente número de veículos causava nas ruas da cidade, tornou ainda mais onerosa a construção de blocos de apartamentos em conjuntos populares, contribuindo para a ineficácia dessa forma de solução para o problema da habitação. 
Posteriormente, após quase uma década de estudos, cabe destacar a promulgação, em 27 de dezembro de 1951, do Plano Regulador da Expansão e Desenvolvimento da Cidade de Santos, Lei $N^{\circ} 1.316$, conhecido simplesmente como Plano Regulador da Cidade, cujo processo de elaboração teve a coordenação de uma Comissão Técnica dirigida pelo urbanista Francisco Prestes Maia.

$\mathrm{Na}$ verdade, essa lei não foi um plano de regulamentação do uso e ocupação do solo, fugindo um pouco do perfil da legislação até aqui estudada. No entanto, por suas implicações, no que concerne à questão da segregação espacial em Santos, vale a pena fazer algumas considerações sobre o mesmo.

O plano de Prestes Maia, a exemplo do que o próprio urbanista, que foi prefeito de São Paulo, preconizou para a capital, era ao mesmo tempo de embelezamento da cidade e de preparo desta para a nova fase de desenvolvimento das metrópoles brasileiras, baseado no uso do automóvel.

Inspirada em diretrizes urbanísticas típicas do final do século XIX, na Europa, a visão de Prestes Maia era a de preparar a cidade para o crescimento, por meio da abertura e alargamento de grandes avenidas. A tônica foi dotar a cidade de eixos viários que integrassem, com fluidez e elegância, as suas áreas e a própria cidade com outras regiões do estado. Na verdade, a equipe de Maia, como apontou NUNES (2001), fez uma ampla revisão dos planos urbanísticos previstos para Santos, desde a virada do século.

Outra preocupação foi a integração desse plano ao Plano Regional de Santos, elaborado pelo mesmo urbanista, que previa a consolidação de Santos como pólo regional e sua expansão em direção ao planalto e ligação ao porto de São Sebastião, no Litoral Norte de São Paulo - em função do maior calado deste - e ao distrito de Vicente de Carvalho, em Guarujá. Este distrito foi por Maia denominado "Nova Santos". Esta denominação revelava o destino reservado para aquele núcleo, o qual seria o de suportar de forma planejada o adensamento populacional que, como já se previa, deveria ultrapassar os limites da llha de São Vicente.

A respeito do Plano Regional, podemos ler em NUNES (1996: 18):

"O Plano Regional de Santos, elaborado por Prestes Maia a pedido do governador do estado e encaminhado pelo Prefeito de Santos, em 21/07/48, à Comissão do Plano. Dentro dos princípios da Carta de Atenas, 'ao contrário dos planos que partem do centro para a periferia, procede inversamente, pela consideração inicial da região, para depois, como num cerco gradual, encarar os problemas urbanos e centrais' MAIA (1950: 155).

Não era propriamente um plano para a cidade, mas para a região em função do porto. No entanto ainda que se tornasse peça fundamental na discussão da cidade, por ser a primeira tentativa de ver a cidade inserida na região, infelizmente não prosperou como Plano Metropolitano, e sua influência no desenvolvimento da cidade acabou se restringindo ao sistema viário através do Plano Regulador. Se bem que algumas de suas idéias ainda vêem à baila". 
O mesmo autor afirmou em seguida:

"O Plano Regional pretendia ser um instrumento de racionalização, orientado pela técnica, com 0 objetivo de orientar os futuros empreendimentos. A intervenção do Estado se daria pela implementação de mudanças no sistema de transporte, principalmente alterações nas ferrovias e construção de pontes, permitindo que a cidade e a região se desenvolvesse.

Em termos de porto, Prestes Maia defendia a idéia de um porto "central", Santos, com ligações diretas com outro porto local, São Sebastião. Ligações essas que privilegiariam o modo ferroviário. Também propunha a instalação de um estaleiro em Santos bem como uma grande ampliação do porto da época, além da remoção da base aérea para outro local, de preferência a Praia Grande".

De fato, pontes e túneis foram projetados por Maia, visando criar novas acessibilidades. Pode-se destacar os projetos de interligação da Zona Leste de Santos com a Zona Noroeste por meio de túnel através do maciço dos morros, o qual criaria novo aceso á Via Anchieta, favorecendo a acessibilidade do turista vindo do Planalto. Ressalta-se também a ligação de Santos insular e continental, por meio da ponte Saboó - Ilha Barnabé, unindo o centro da cidade com o continente, passando junto àquela ilha. É importante, também, a ligação entre Santos e Vicente de Carvalho, através de ponte elevadiça, ao sul do cais dos Outeirinhos atual bairro do Macuco. Outro aspecto interessante foi o a previsão de arruamento de áreas de influência destas obras, como no bairro do Jabaquara, entre outras, que foram executadas apenas parcialmente.
A maioria dessas propostas não se concretizou. Porém, a abertura do túnel Rubens Ferreira Martins, sob o Monte Serrat, que permitiu uma ligação mais direta entre o centro e os bairros da área intermediária da zona leste e a própria orla; bem como o alargamento da rua João Pessoa, principal via de comércio no centro, podem ser destacados como alguns dos principais projetos contidos no plano, efetivamente realizados, ainda que alguns tenham sido implantados com muito atraso. Este é o caso do prolongamento da avenida Senador Feijó, no bairro da Encruzilhada, efetivado apenas em 1996. Esta obra era prevista, na verdade, desde o início do século $X X$, e foi elencada como prioridade no Plano Regulador.

Ao mesmo tempo o plano previa um grande número de alargamentos e prolongamentos de vias existentes, bem como a abertura de novas artérias, visando aumentar a fluidez do transito e a capacidade de adensamento da cidade. A lei estabeleceu, ainda, uma série de intervenções de cunho turístico, em diversas áreas da cidade, como o Valongo e Morro da Nova Cintra, por exemplo, visando criar outros focos de atração alternativos às praias, sempre com uma visão monumentalista própria desse tipo de plano.

Muitas dessas propostas implicavam na desapropriação de grandes áreas já consolidadas da cidade, e conseqüente remanejamento de quadras e lotes, em alguns casos, em territórios habitados por população de baixa renda. Pelo seu alto custo social e econômico, grande parte do conjunto das propostas não foi implementada. Porém, nos casos em que os alargamentos, prolongamentos e aberturas ocorreram, o impacto foi importante, a exemplo do que já ocorrera no Rio de Janeiro e em São Paulo, em intervenções semelhantes. 
O valor pago pelas desapropriações nem sempre foi suficiente para que a família removida pudesse adquirir lotes em áreas próximas da cidade, vindo a agravar o processo de exclusão espacial em marcha desde o final do século XIX. Na verdade, os impactos sociais da execução desse plano só poderão ser analisados com maior clareza em uma investigação específica. No entanto, pode-se afirmar que as diretrizes viárias foram efetivadas em pequena proporção, provocando o congelamento de determinadas áreas da cidade, onde deveriam incidir obras viárias futuras que nunca chegaram a ocorrer - ou que muito tardaram a serem executadas. Em função disso, ocupações de baixa renda surgiram por conta da desvalorização dos terrenos atingidos por estas diretrizes, como é o caso da Favela Caldeirão do Diabo, atualmente denominada Vila Santa Casa, vinculada ao prolongamento da avenida Senador Feijó.

Para a finalidade deste trabalho é importante destacar, como apontou NUNES (2001: 159), que o tema habitação não ocupou a equipe de Maia na elaboração do Plano Regulador, provavelmente pela conjuntura política da época.

O Plano Regulador foi revisado tão somente no princípio da década de 1990, resultando na aprovação da Lei Complementar $\mathrm{N}^{\circ} 151$, de 1994, que objetivou, por meio de uma revisão criteriosa daquele plano, suspender ou mitigar os impactos de diversas diretrizes viárias estabelecidas ${ }^{87}$.

\footnotetext{
${ }^{87}$ Uma interpretação detalhada de todo o processo de elaboração dos planos Regional e Regulador, para Santos, pode ser obtida em NUNES (2001:130-177)
}

No mesmo ano, antes mesmo da sanção do Plano Regulador, uma série de dispositivos, entre eles a Lei $\mathrm{N}^{\circ}$ 1.203 , de 16 de maio e os decretos $N^{\circ} 492$, de 28 de junho e $N^{\circ} 522$, de 10 de dezembro, tratou da "legalização" de construções de madeira, estabelecendo "bolsões" nos bairros da Vila Belmiro e Ponta da Praia, onde os chalés seriam tolerados. Por certo eram essas áreas desprezadas pela população de alta renda, onde não havia pressão imobiliária que justificasse a proibição dos chalés.

Mais tarde, as leis $\mathrm{N}^{\circ} 1.746$, de 19 de setembro de 1955 e $\mathrm{N}^{\circ}$ 1.811, de 7 de janeiro de 1956, criaram, respectivamente, mais alguns bolsões onde os chalés poderiam ser legalizados e uma grande "área de exclusão", ao longo das principais avenidas em toda a orla marítima, até aproximadamente a linha da Estrada de Ferro Sorocabana, que corta a cidade desde a divisa com São Vicente até o cais, onde essas construções não poderiam ser legalizadas.

$\mathrm{Na}$ verdade, essa região da cidade, como um todo e não somente ao longo das avenidas, ficou marcada por esse e outros dispositivos que levaram à segregação, influindo fortemente no mercado imobiliário, de maneira a criar duas "cidades" dentro da Zona Leste de Santos. Hoje essas áreas são conhecidas como orla, área de alta e média renda, compreendendo os bairros do José Menino, Pompéia, Gonzaga, Boqueirão, Embaré, Aparecida e Ponta da Praia e zona intermediária, aproximadamente a área onde foi permitida a legalização, correspondendo aos bairros do Estuário, Macuco, Encruzilhada, Campo Grande, Vila Belmiro, Jabaquara, Marapé e parte da Vila Mathias. No entanto, alterou-se paulatinamente o perfil imobiliário dessa zona intermediária, sobretudo a partir da década de 
80, quando a classe média começou a ocupá-la mais efetivamente.

Esse fenômeno se deve sobretudo pela ocupação quase que completa da orla, que forçou a burguesia a buscar localizações mais distantes da praia, em função da escassez de lotes disponíveis para a construção de edifícios de apartamento próximos ao mar.

Ainda em 1956, pela Lei $N^{\circ} 1.831$, de 9 de maio, deu-se a revisão do zoneamento estabelecido pelo Decreto-Lei $N^{\circ}$ 403 , de 1945. As principais alterações introduzidas pela lei, que continha um total de 50 artigos, distribuídos em 5 capítulos, foram a consolidação dos Núcleos Comerciais nas Zonas Residenciais, estabelecidos ao longo das principais vias da Zona Leste da cidade (ver Mapa à p. 143); o notável aumento da Zona Portuária, sobretudo em direção à Ponta da Praia, já preparando a cidade para a ampliação do porto concluída na década de 1970; e a ampliação da ZR3, na Zona Noroeste, ao longo da avenida Nossa Senhora de Fátima, onde se iniciava um processo que tornou aquela região da cidade a localização da população de baixa renda, por excelência.

Os Núcleos Comerciais admitiam as seguintes atividades, conforme estabelecido pelo Código de 1945: no caso da ZR1, as atividades previstas para a ZCC; no caso da ZR2 e ZR3, as previstas para a ZCS. Com isto, reafirmou-se a intenção de trazer os serviços e o comércio em maior intensidade para as áreas habitadas pela burguesia, fixando pólos que até hoje estão em processo de desenvolvimento.

No Capítulo III, tratou-se da utilização das zonas, em que foram alterados alguns índices urbanísticos, mas os usos permaneceram praticamente os mesmos. Na ZCC os edifícios poderiam ter até $52 \mathrm{~m}$ de altura, em ruas com mais de $10 \mathrm{~m}$ de largura. Na ZR1, a taxa de ocupação ficou limitada a $65 \%$ da área do lote e o número de pavimentos não poderia exceder a 3 , exceto nas principais avenidas da "área nobre" criada pela Lei $N^{\circ} 1.811$, de 1956, onde os edifícios poderiam atingir $52 \mathrm{~m}$ de altura nas primeiras fileiras de quadras junto à praia e $37 \mathrm{~m}$ nas demais.

Esse dispositivo, certamente foi feito "sob encomenda" pelo segmento da promoção imobiliária que atuava na orla, desde o princípio da década de 50 , construindo os edifícios de apartamento para segunda residência. Essa alteração possibilitou a fixação do padrão de "muralha", abordado profundamente por SEABRA (1979). Nessa mesma zona passaram a ser tolerados usos típicos da função turística que essa área da cidade passava a desempenhar, os quais até hoje em muitos casos provocam algum tipo de conflito com o uso residencial de caráter permanente.

O artigo 39 possibilitou edificar aproveitando o desnível dos terrenos nos morros, construindo número limitado de pavimentos "do lado em que o terreno desce", respeitada a altura para a zona do respectivo logradouro. Tal dispositivo poderia estar refletindo uma certa pressão para tolerar-se o adensamento dos morros, já uma área bastante habitada da cidade. Ainda, o artigo 40 permitiu nas ZR a construção de prédios conjugados, em grupos de 2 nas ZR1 e ZR2, e grupos de 6 na ZR3, reafirmando a "vocação" popular desta zona.

Finalmente, outra novidade apresentada por essa lei estava no fato de prever a promulgação posterior, através de decreto do Prefeito, de disposições referentes à "parte 
urbana de Bertioga", então um distrito de Santos, no litoral mais ao norte. Foi a primeira vez na legislação em que se manifestava a preocupação em definir diretrizes urbanísticas para aquele povoado, então limitado pelo vilarejo em torno do Forte São João, correspondendo ao atual centro da cidade de Bertioga.

Logo em seguida à revisão do Código de 1945, a Lei $N^{\circ}$ 1.905, de 7 de dezembro de 1956, fez pequena alteração na ZCS, estendendo-a até o Cemitério do Saboó, no bairro de mesmo nome, onde termina a Via Anchieta. Essa era a direção oposta a que as classes de mais alta renda seguiam rumo à orla, e acompanhava o eixo da principal entrada da cidade, para quem vem do planalto. Portanto, essa alteração era bastante natural, uma vez que nesse eixo estabeleciam-se transportadoras, postos de abastecimento de combustível e oficinas, vinculados ao cada vez mais intenso tráfego rodoviário de carga demandado pelo porto.

No ano seguinte, a Lei $\mathrm{N}^{\circ} 1.972$, de 26 de agosto de 1957, alterou o perímetro urbano da cidade, de forma a nele incluir toda a área insular, já então ocupada em sua maior parte. Com isso, na vigência de um zoneamento bastante detalhado, esse perímetro deixava de funcionar como barreira legal para o estabelecimento de submoradias nas áreas mais valorizadas da ilha. Esse obstáculo passou a constituir-se exclusivamente pelo zoneamento e os índices urbanísticos a ele associados.

Em uma das últimas referências ao zoneamento de 1956, a Lei $N^{\circ} 2.173$, de 27 de agosto de 1959, regulamentou o funcionamento de estabelecimentos de comercialização de gêneros alimentícios extensivos às residências, tais como mercearias, confeitarias e sorveterias, fora dos núcleos comerciais das ZR, desde que já existentes à época da promulgação desta lei. $\mathrm{Na}$ verdade, na busca de estabelecer um território exclusivo, livre do incômodo de atividades de grande impacto, a burguesia nunca fez restrições ao surgimento do pequeno comércio nas zonas residenciais.

A década de 1960 é a década do planejamento por excelência. Até a promulgação do Plano de 1968, foram mínimas as alterações no zoneamento vigente desde de 1956, porém, preparava-se o caldo de cultura para a formação de uma ideologia planejadora nos meios técnicos e políticos da cidade. Ideologia que, como já vimos, tem origem nos primeiros CIAM e não era inédita em Santos, mas atingiu nessa década o seu auge. Tratava a Municipalidade de construir um corpo técnico preparado para o planejamento da cidade e, mais do que isso, reunir as principais lideranças de Santos em torno desse objetivo, que culminou em 1968, com a aprovação do Plano Diretor, já na vigência do regime de exceção ${ }^{88}$.

\footnotetext{
${ }^{88}$ Vale notar que quando nos referimos a essas lideranças, cidadãos de destaque, estamos falando de representantes do pensamento burguês, não havendo qualquer espaço para a participação popular na discussão do futuro da cidade, seja via sindicatos de operários ou entidades de bairro, exceção feita ao Centro dos Estudantes de Santos.
} 





Assim, a maioria das leis e decretos do período ocupava-se do tema. O Decreto $\mathrm{N}^{\circ} 2.087$, de 19 de junho de 1961, criava uma assessoria de pesquisa e planejamento, junto ao gabinete do Secretário de Obras. Mais tarde, pelo Decreto $\mathrm{N}^{\circ} 2.128$, de 28 de setembro de 1961, alterou-se o Decreto $N^{\circ} 552$, de 12 de maio de 1952, que dispunha da constituição da Comissão Consultiva do Plano da Cidade. Em seu artigo $1^{\circ}$ foi fixado em vinte o número de "cidadãos eminentes, representativos de diversas atividades sociais" e no artigo $2^{\circ}$ criou-se seis subcomissões permanentes, referentes às distintas áreas da administração municipal: Morros e Baixadas; Vias de acesso ao Porto; Turismo, Recreação, Cultura e Propaganda; Circulação e Serviços Públicos; Código de Obras; e Dinamização do Plano.

O Decreto $N^{\circ} 2.268$, de 12 de maio de 1962, revogou o Decreto $\mathrm{N}^{\circ} 2.087$, de 19 de junho de 1961 e reforçou a intenção da administração municipal em planejar o crescimento da cidade, ao instituir um Grupo Executivo de Planejamento subordinado diretamente ao Prefeito Municipal, José Gomes. A essa instância competiria "a elaboração do Planejamento Municipal e das medidas necessárias à sua aplicação, defesa, coordenação, controle e entrosamento com o Plano Regional e os servidores estaduais e federais correlatos".

Pelo Decreto $N^{\circ} 2.578$, de 10 de dezembro de 1963, foram criadas administrações municipais na área continental, sob a forma de subprefeituras. Eram estas as subprefeituras previstas: Bertioga, Itatinga e Jurubatuba. A primeira correspondia à maior parte do território do atual município de mesmo nome. A segunda, em grande parte deste mesmo território, compreendia a área em que se localiza a hidroelétrica geradora de energia para o porto. A última compreendia a maior parte da atual área continental de Santos.

\subsubsection{A legislação urbanística do milagre econômico}

O golpe de 31 de março de 1964, a nível local resultou na deposição do prefeito José Gomes, nesta mesma data. Nos anos que se seguiram a cidade logrou eleger um único prefeito, o engenheiro Silvio Fernandes Lopes, para um segundo mandato, a partir de 14 de abril de $1965^{89}$. Em abril de 1969 a cidade foi declarada Área de Segurança Nacional e perdeu sua autonomia política por mais de quinze anos, período em que os seus dirigentes máximos passaram a ser nomeados ou pelo Presidente da República, ou pelo Governador do Estado. Foi o período do chamado milagre econômico, cujas conseqüências para a RMBS, no que diz respeito à questão da exclusão espacial, foram bastante danosas, conforme pudemos abordar no Capítulo 3.

No entanto, nos primeiros anos do regime militar a administração municipal prosseguiu na mesma linha do início da década, aprofundando sua convicção no planejamento urbano como instrumento de controle do crescimento da cidade e propulsor de seu desenvolvimento.

A Lei $N^{\circ} 2.852$, de 27 de abril de 1964, estabeleceu o Conselho Municipal de Planejamento, "junto ao Gabinete do Prefeito" composto de 26 representantes de várias entidades e órgãos públicos, dentre estes o chefe do Grupo Executivo de Planejamento, com a atribuição de "opinar, traçar a orientação, recomendar modificações e sugerir

\footnotetext{
${ }^{89}$ Silvio Fernandes Lopes já havia governado a cidade entre 1957 e 1961.
} 
soluções quanto aos problemas e projetos relativos ao Plano Diretor do Município e do Plano Regional". Nota-se que é justamente nessa época em que o termo Plano Diretor começa a ser empregado na legislação municipal, consolidando-se um processo, iniciado no pós-guerra, com a constituição da primeira comissão consultiva do Plano da Cidade, que foi resultar, em 1968, na promulgação do Plano Diretor do Município.

Foi a Lei $N^{\circ} 2.977$, de 24 de setembro de 1964, que estabeleceu uma das poucas alterações no zoneamento de usos de Santos, nesse período imediatamente anterior à promulgação do Plano de 1968. Esse instrumento vedou o licenciamento de "Cabarets, Bowling Centers ou Boliches, Tiro ao Alvo, ou quaisquer outros aparelhos destinados à prática de jogos (...) na 1 a Zona Residencial do Município de Santos". Tratava-se evidentemente de reforçar o estabelecimento de áreas livres de incômodos que viessem a colocar em risco a exclusividade do uso do solo exigida pelos padrões burgueses.

A Lei $N^{\circ} 3.064$, de 30 de dezembro de 1964, ampliava os núcleos comerciais da Zona Noroeste, nos dois lados da avenida Nossa Sra. de Fátima, antiga estrada de ligação entre Santos e São Vicente, em toda a sua extensão. Consolidava-se, dessa forma, o estabelecimento do maior eixo de comércio e serviços da Zona Noroeste e de São Vicente, pois o prolongamento daquela avenida neste município, avenida Antônio Hemmerich, é o maior eixo comercial da cidade.

Na última alteração do zoneamento estabelecido em 1956, a Lei $N^{\circ} 3.345$, de 7 de outubro de 1966, extinguia a $3^{\text {a }}$ Zona Residencial e a $5^{\text {a }}$ Subzona, criando uma grande
Zona Mista ao longo do eixo Via Anchieta e avenida Martins Fontes - via de entrada da cidade - até o cemitério do Saboó. Tratava-se, portanto, de um aprofundamento do disposto na Lei $\mathrm{N}^{\circ} 1.905$, de 7 de dezembro de 1956, consolidando-se aquele eixo como de prestação de serviços vinculado ao porto.

Contudo, como esclarece a denominação da zona, não era vedado o uso habitacional e como este não era o vetor de crescimento da alta renda, acabaram por surgir vários núcleos habitacionais de baixa renda ao longo deste eixo, como os loteamentos Vila Haddad, Chico de Paula e mais tarde as favelas da Vila Alemoa, do Pantanal, os loteamentos do Jardim São Manoel e Piratininga e o conjunto habitacional Athiê Jorge Coury.

De fato, os espaços compartilhados entre habitação de baixa renda e atividades portuárias e retroportuárias tornaram-se comuns, a partir da década de 1950, em Santos. A exemplo dos bairros contíguos ao porto, na Zona Leste, como Macuco, Estuário e Ponta da Praia, na Zona Noroeste, os bairros Saboó, Alemoa, Chico de Paula, Piratininga, São Manoel e Santa Maria abrigam uma população de baixo poder aquisitivo, que divide seus espaços de moradia com um número muito grande de atividades vinculadas ao porto, gerando inúmeros conflitos decorrentes dos impactos dessas atividades e até mesmo riscos ambientais graves, pelo transporte de cargas perigosas ao longo do sistema viário da entrada da cidade.

$\mathrm{Na}$ década de 60 a Zona Noroeste consolidou-se como a grande área de concentração da população de média e baixa renda na cidade. Nessa época já se fazia sentir plenamente um dos principais efeitos do zoneamento 
funcionalista, aplicado desde as primeiras décadas do século, que foi o de "empurrar" essa população para a Zona Noroeste, morros e municípios vizinhos. A pressão por moradia era, então, bastante significativa em meados deste decênio, naquela região. É nesse período que surgem os primeiros projetos de urbanização de núcleos ocupados de forma desordenada, como no bairro da Areia Branca, junto ao cemitério de mesmo nome.

A recém criada COHAB-St implantou um loteamento destinado a famílias de baixa renda, que já residiam no local, em uma das primeiras favelas da Zona Noroeste. Foi um dos projetos pioneiros de regularização fundiária em Santos, e pelo Decreto N³.257, de 19 de janeiro de 1967, estabelecia-se critérios urbanísticos para a construção nos lotes, menos restritivos que os vigentes desde a Lei 1.831, de 1956, que beneficiavam a construção de moradias de baixo custo.

$\mathrm{Na}$ verdade, esse projeto foi uma exceção, pois entre as décadas de 50 e 80 houve total predomínio dos conjuntos habitacionais, horizontais ou verticais, como solução oficial para o problema da moradia em Santos, tal como ocorreu nas principais cidades do país. Na Zona Noroeste, nesse período, podemos destacar a construção dos conjuntos General Arthur da Costa e Silva, no Jardim Castelo, General Dale Coutinho, na divisa do mesmo bairro e Jardim Rádio Clube e posteriormente o conjunto dos Estivadores, na Vila São Jorge, além de vários projetos de menor porte, no Castelo e Rádio Clube, a cargo da COHAB-St.

Marcando o encerramento da fase desenvolvimentista, um conjunto de códigos cuja vigência estendeu-se por mais de vinte anos veio a estabelecer a base legal que marcou a mais importante experiência do planejamento centralizador e do zoneamento funcionalista em Santos. São estes, a Lei 3.529, de 16 de abril de 1968 - Plano Diretor Físico do Município; a Lei 3.530, de 16 de abril de 1968 - Código de Edificações do Município de Santos; a Lei 3.531, de 16 de abril de 1968 - Código de Posturas do Município de Santos e a Lei 3.533, de 16 de abril de 1968 - Normas Ordenadoras e Disciplinadoras da Urbanização e da Preservação da Paisagem Natural dos Morros de Santos.

De maneira inédita separava-se regulamentação urbanística, como normas para parcelamento do solo e urbanização de glebas em geral, de normas edilícias e posturas municipais. Ao mesmo tempo, procurava-se estabelecer critérios para a ocupação dos morros, já largamente utilizados como opção de moradia para a baixa renda, ainda que de forma bem menos detalhada que na parte plana da cidade.

Este trabalho abordará especificamente as Leis $\mathrm{N}^{\circ} 3.529 \mathrm{e}$ $\mathrm{N}^{\circ} 3.533$, pois de várias formas, são estas que trazem elementos de reflexão para o objeto da presente pesquisa, uma vez que a questão das posturas municipais e do controle do processo de edificação não vieram a afetar a dinâmica da segregação espacial na cidade de Santos em igual medida.

Da mesma maneira, não será objeto de estudo a Lei $\mathrm{N}^{\circ}$ 4.078, de 3 de dezembro de 1976, que criou o Código de Uso do Solo e Proteção dos Recursos Naturais do Distrito de Bertioga. Antigo vilarejo de pescadores, fundado no século XVI, quase ao mesmo tempo em que Santos e São Vicente, Bertioga conquistou sua autonomia administrativa 
pela Lei $N^{\circ} 7.664$, de 30 de dezembro de 1991, e encontrase fora do recorte espacial do objeto deste estudo.

O Plano de 1968, composto por 406 artigos, distribuídos em 17 capítulos, foi sancionado pelo prefeito Silvio Fernandes Lopes, em 16 de abril de 1968. Este plano teve sua vigência prolongada até 1998, quando foram sancionadas as leis complementares $\mathrm{N}^{\circ} 311$ e $\mathrm{N}^{\circ} 312$, que dispõem do Plano Diretor e do Ordenamento do Uso e Ocupação do Solo da Área Insular, respectivamente, em vigor atualmente.

Os cinco primeiros capítulos do Plano de 1968 tratavam de aspectos relativos à configuração física do município, incluindo-se 0 então distrito de Bertioga, tais como coordenadas geográficas, divisão em áreas urbana, de expansão urbana e rural, assim como divisão em bairros. Os capítulos VI e VII tratavam do sistema viário, alinhamento e nivelamento de terrenos.

No entanto, contrariando a tendência predominante dos planos elaborados em outros municípios naquela época, o Plano de Santos incluía entre seus dispositivos o zoneamento de uso e ocupação do solo, tratados em seu capítulo VIII, aprofundando o detalhado zoneamento do Código de 1945, alterado em 1956.

O zoneamento aplicava-se apenas ao território insular, excetuando-se os morros, os quais seriam objeto de regulamentação pela Lei $\mathrm{N}^{0} 3.533$ do mesmo ano. Eram as seguintes as 11 zonas criadas pelo Plano de 1968: Turística - ZT, Residencial - ZR, Mista Leste - ZML, Comercial Residencial - ZCR, Comercial Industrial - ZCI, Comercial Central - ZCC, Comercial Secundária - ZCS, Mista
Noroeste - ZMNO, Industrial - ZI, Residencial Noroeste ZRNO e Portuária - ZP (Ver Mapa à p. 153).

A ZT correspondia às duas primeiras fileiras de quadras ao longo das praias, onde se concentravam os hotéis, pensões e demais atividades vinculadas ao turismo balneário, bem como os edifícios de maior gabarito, que surgiram nas décadas de 1950 e 60, servindo de residência de veraneio.

A ZR seria a área dos bairros onde habitava a população de mais alta renda, ou seja, os bairros da orla marítima, mais o Marapé, Vila Belmiro, Campo Grande, Encruzilhada, bairros majoritariamente de classe média e a parte do Estuário mais afastada do porto (ver Figura 32).

A ZCR compreendia a grande área intermediária da ilha no centro da Vila Mathias, onde predominavam atividades comerciais de maior impacto como oficinas, marcenarias, tornearias, serralherias, lojas de automóveis e outras.

A ZML consistia na faixa ao longo do porto, excetuando-se a área de jurisdição federal, onde durante vinte anos estabeleceram-se inúmeras transportadoras, galpões e pátios de armazenagem de carga.

A ZP seria a área portuária de jurisdição federal, administrada pela Companhia Docas de Santos - CDS, depois sucedida pela estatal Companhia Docas do estado de São Paulo - CODESP, após o vencimento da concessão do porto à primeira.

A ZCS seria a área do Valongo, onde também predominavam as mesmas atividades da ZML. Esses mesmos usos também ocorriam na $\mathrm{ZCI}$, área onde também 
se localizavam indústrias de moinhos de trigo tradicionais da cidade.

A ZCC seria o núcleo original da cidade, seu centro comercial e de serviços, já transformado em centro popular, em função da competição das áreas comerciais da orla como Gonzaga e Boqueirão, que serviam às elites.

$\mathrm{A} \mathrm{ZI}$, que nunca se consolidou como um distrito industrial de fato, correspondia ao bairro da Alemoa, onde se estabeleceram empresas transportadoras e de armazenagem de carga geral e de granéis líquidos e sólidos.

A ZMNO seria uma extensão da ZI, com a diferença que nesta zona já existiam núcleos habitacionais de média e baixa renda, que disputavam espaço com as atividades vinculadas ao porto, tal como ocorria com a ZML.

Por último, a ZRNO seria a área onde se concentrou a população de média e baixa renda, a partir da década de 50. Era a área mais residencial da Zona Noroeste, a grande região popular da cidade, com padrões de urbanização, infra-estrutura e serviços bem inferiores aos da Zona Leste.

Quanto aos usos permitidos, o Plano de 1968 aprofundava e atualizava o estabelecimento de zonas de exclusividade na Zona Leste, por meio da ZR, onde as atividades comerciais e de serviços continuavam a ser restritas, como ocorreu com a ZR1 do Código de 1945. A figura dos corredores de atividades comerciais, criada pela Lei 1.831, de 1956, foi substituída pela vinculação desses usos às vias de maior importância, conforme classificação do sistema viário criada pelo próprio Plano de 1968.
O zoneamento funcionalista radicalizou-se com este plano, pelo estabelecimento definitivo de áreas residenciais exclusivas, pela proibição do uso habitacional na ZCC, que contribuiu para aprofundar o movimento pendular da população que habitava na orla e trabalhava no centro; pelo estabelecimento de áreas segregadas ao uso portuário; e pela ampliação das áreas de uso misto, cujos conflitos entre atividades portuárias e residências expulsou, sobretudo a classe média para bairros mais distantes do porto.

Quanto à ZP, houve um retrocesso em relação á legislação anteriormente em vigor, que podemos interpretar como sinal dos tempos. O Plano de 1968 considerou a área de jurisdição federal do Porto, como uma região em que o licenciamento de atividades era de competência exclusiva da União.

Quanto aos índices urbanísticos, o Plano de 1968 notabilizou-se pelo alto adensamento admitido nas ZR e ZT, onde era permitido edificar até 6 e 5 vezes a área do lote, respectivamente. Esses índices permitiram a fixação de um padrão demográfico bastante alto, mesmo em relação às demais cidades litorâneas do país, consolidando os bairros da orla como os mais populosos da cidade.

No aspecto da ocupação dos terrenos, em função da pequena dimensão dos lotes já existentes então, na quase totalidade dos bairros da orla, admitia-se um alto índice, que chegava a $60 \%$ da área do lote nas ZR e ZT, contribuindo para o agravamento das más condições de ventilação e insolação na Zona Leste da cidade. 


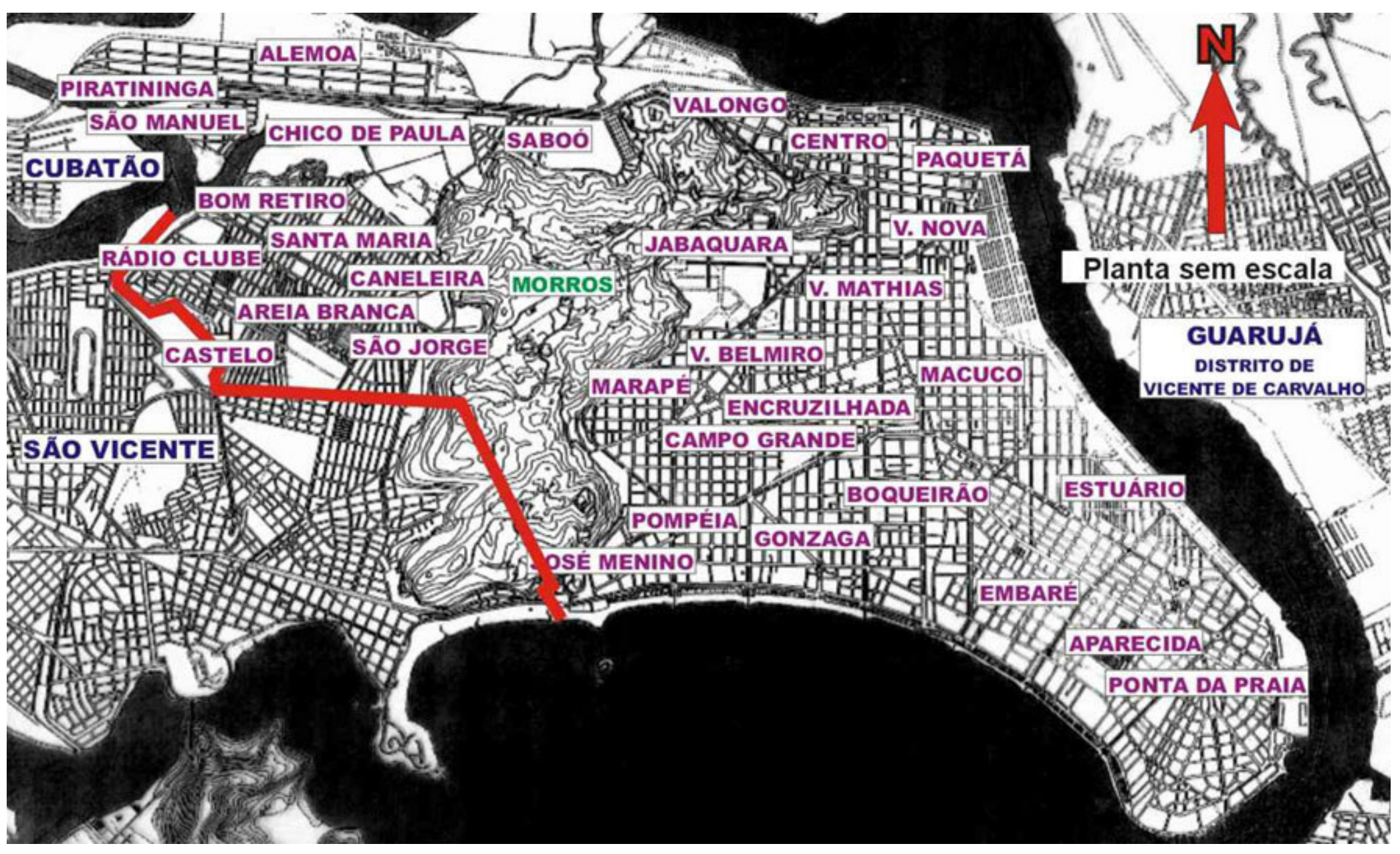

Figura 32 - Divisão atual dos bairros da área insular do município de Santos. Fonte: Plano Diretor Físico do Município - Lei 3.529/68, com alteração pela Lei Complementar $\mathrm{N}^{\circ} 312$, de 23 de novembro de 1998. 
O Capítulo IX do plano tratava dos requisitos para parcelamento, desmembramento ou reagrupamento de lotes, os quais foram aplicados, sobretudo na Zona Noroeste, pois àquela altura a Zona Leste já estava quase inteiramente parcelada. É importante destacar, para a finalidade deste trabalho, a existência de alguma preocupação dos legisladores de então com a questão da habitação popular, tal como ocorreu nos códigos anteriores.

A Seção IV deste capítulo, "Dos Critérios Urbanísticos no Planejamento de Terrenos para Fins Populares", visava "estimular a construção de moradias econômicas, destinadas a pessoas de baixa renda". Conforme o artigo 124, e em seu artigo 126, admitia-se lotes com área mínima de $160 \mathrm{~m}^{2}$, quando as dimensões mínimas exigidas para o restante dos lotes seriam de $300 \mathrm{~m}^{2}, 200 \mathrm{~m}^{2}$ e $1000 \mathrm{~m}^{2}$, para fins residenciais, comerciais e industriais, respectivamente, conforme o artigo 116.

No entanto, de pouco serviu essa "liberalidade", pois esses parcelamentos populares só eram admitidos no distrito de Bertioga, na Zona de Expansão Urbana, a área intermediária entre a orla marítima e o Parque Estadual da Serra do Mar. Esse dispositivo denunciava a intenção, malograda, de afastar as classes de baixa renda para localizações mais distantes ainda.

Para a área insular, mesmo na Zona Noroeste, aplicava-se a área mínima para lotes de $300 \mathrm{~m}^{2}$, o que tornava praticamente impossível a implantação de loteamentos regulares para a população que ali habitava. Esse é um dos motivos que dificultaram a implantação de loteamentos regulares em bairros da Zona Noroeste, como Bom Retiro, São Manoel e outros.
Como nessa época o valor imobiliário, mesmo na Zona Noroeste, começasse a crescer, o que se viu foi a burla sistemática desse dispositivo, com a implantação de alguns parcelamentos em que o lote mínimo era subdividido, com a criação de um "condomínio de duas moradias", fazendo com que, de forma criativa, na prática a exigência de área mínima caísse para a metade.

Porém, mesmo os lotes subdivididos, com $150 \mathrm{~m}^{2}$, estavam fora do alcance dos mais pobres, que continuaram a procurar localizações menos privilegiadas, geralmente nos morros e nos manguezais, áreas essas com ocupação também restrita pelo Plano e pela Lei $\mathrm{N}^{0} 3.533$, de 1968. O que prevaleceu até 0 final da década de 80 , foi 0 consentimento velado da ocupação dessas áreas, em que pese o histórico de tragédias vinculadas ao risco geológico.

Quase duas décadas depois de sua promulgação, em 21 de junho de 1986 e em 27 de novembro do mesmo ano, o Plano de 1968 sofreu duas de suas principais alterações, dada pelas Leis $\mathrm{N}^{\circ} 174$ e 209, respectivamente. Essas alterações foram resultado de forte pressão do setor da produção imobiliária, para que se mudasse o perfil dos projetos de edifícios pluri-habitacionais.

Pela Lei $\mathrm{N}^{\circ} 174$, na ZT o coeficiente de aproveitamento estabelecido pelo Plano de 1968, que era de 6 vezes a área do lote, seria reduzido para 5 vezes. O número máximo de pavimentos que era 10 , subiu para 14 ; e a taxa de ocupação, que era de $50 \%$, caiu para $40 \%$, para edifícios com mais de seis pavimentos.

Visando ampliar, também, o número máximo de pavimentos admitido na área mais valorizada da ZR, ou seja, a região 
localizada nos bairros da orla, entre a linha férrea da FEPASA - antiga E. F. Sorocabana - foi criada pela Lei $\mathrm{N}^{\circ}$ 209 a Zona Residencial Especial, sendo que o coeficiente de aproveitamento original da ZR, que era de 6 vezes a área do lote, caiu para 5 vezes. No entanto, o número máximo de pavimentos que era 10, subiu para 13. A ocupação máxima que era de $60 \%$ passava a $40 \%$, para os edifícios com mais de seis pavimentos.

O resultado dessas duas leis foi uma imediata ampliação do aproveitamento dos lotes nestas áreas, já bastante valorizados, pelo surgimento de um padrão de lançamentos imobiliários mais exclusivo, apressando o processo de verticalização e tornando mais restritivo o estabelecimento das classes de menor renda e de setores da classe média, nessa privilegiada porção da cidade.

A Lei $N^{\circ} 3.533$, de 16 de abril de 1968, que estabeleceu as Normas Ordenadoras e Disciplinadoras da Urbanização e da Preservação da Paisagem Natural dos Morros de Santos, visava atuar sobre as questões específicas da urbanização dos morros, sendo as gerais remetidas para o próprio Plano Diretor Físico. No entanto, essa lei era bastante genérica, no que respeitava a estabelecimento de critérios para parcelar e edificar.

A Lei dos Morros, como ficou mais conhecida a lei $\mathrm{N}^{\circ} 3.533$, foi baseada em relatório da empresa contratada para assessorar a sua elaboração, a Tecnosolo, que apontava várias diretrizes visando 0 controle da ocupação e preservação da paisagem natural dos morros, a partir do levantamento das áreas onde já haviam ocorrido deslizamentos, áreas a serem estabilizadas e obras de caráter urgente.
A lei continha 53 artigos, divididos em 14 capítulos que tratavam de: disposições gerais; urbanização e preservação da paisagem; compartimentação dos morros em oito áreas; sistema viário; urbanização da área recreativa da Nova Cintra; exigências paisagísticas, para aprovação de plano de urbanização, para edificação e exploração de pedreiras, barreiras e saibreiras; obras de estabilização de taludes; controle da supressão da cobertura vegetal, por meio da proibição de culturas em determinados locais; interdição de áreas suscetíveis a deslizamentos; implantação do planejamento físico; e disposições finais.

$\mathrm{Na}$ verdade, desde o princípio de sua ocupação, a região dos morros foi o território da informalidade. Informalidade dada pela condição social de seus moradores, quase que exclusivamente de baixa renda. A municipalidade nunca cuidou de estabelecer aí regras detalhadas de ocupação, tal qual foi feito para a planície.

No entanto, uma parte dos morros, a Nova Cintra, por ser uma região predominantemente plana e possuir uma considerável reserva vegetal bem preservada, sofreu um processo paulatino de ocupação por população de média e alta renda, que ali procurou estabelecer loteamentos de alto padrão. Foi justamente sobre a Nova Cintra que a Lei $\mathrm{N}^{\circ}$ 3.533 concentrou as maiores atenções, detalhando um pouco mais sua ocupação. Para os demais morros, segundo dispunha o artigo 17, "a ocupação ou a utilização de qualquer área (...), só poderá ser permitida pela Prefeitura após a comprovação de sua viabilidade técnica", critério este bastante subjetivo.

O morro de Santa Terezinha, de grande declividade e bastante suscetível a acidentes geológicos, foi objeto de 
implantação de um condomínio fechado de alta renda, a "Vila Residencial Jardins de Santa Tereza", o qual foi regulamentado nesta lei, no sentido de que suas construções passaram a ser passíveis de legalização, diferentemente das milhares de moradias da população de baixa renda que residia nos morros. Esse privilégio dava bem a medida do tratamento dispensado pelos legisladores a uma e a outra classe social na Santos do período militar.

O Capítulo XIII previa a criação de um órgão, denominado Grupo Executivo dos Morros de Santos - GEMOSAN, a ser implantado posteriormente, por meio de um convênio entre a Prodesan ${ }^{90}$ e o Departamento Nacional de Obras e Saneamento - DNOS. Na verdade, esse órgão jamais foi criado, sendo que a primeira estrutura específica para lidar com as questões dos morros, o Grupo Executivo dos Morros - GEMPO - veio a ser criada, por decreto municipal, apenas em 1989.

A idéia era que esse órgão fosse paulatinamente regulamentando os critérios de ocupação dos demais morros, mas como tal não ocorreu, a informalidade continuou a ser a regra naquela região. $\mathrm{Na}$ verdade, o grande instrumento utilizado pela municipalidade, para controlar a ocupação nos morros, surgiu em 1978 com a conclusão da primeira Carta Geotécnica dos Morros, elaborada pelo Instituto de Pesquisas tecnológicas do Estado de São Paulo - IPT, visando apontar as áreas com maior e menor risco de ocupação no maciço central da llha de São Vicente, por meio de um levantamento bastante

90 Progresso e Desenvolvimento de Santos, companhia de economia mista criada na década de 70, para executar a política de desenvolvimento da cidade, na qual estava alocado o setor de planejamento da municipalidade. detalhado das condições topográficas, geotécnicas e do estado da cobertura vegetal dos morros.

Para a Nova Cintra, a Lei dos Morros previa a implantação de um pólo de recreação e turismo, o Parque da Montanha, devido ao grande valor de sua paisagem natural, dotado de vários equipamentos e de um condomínio residencial turístico. Na verdade, estabeleceu-se ali um loteamento de alta renda, de moradores da própria cidade.

Portanto, podemos afirmar que a Lei $\mathrm{N}^{\circ} 3.533$ foi insuficiente para o controle da ocupação nos morros, pois não considerava o fato de que os morros, em sua maior parte, eram uma alternativa habitacional para a baixa renda, passando sempre ao largo dessa questão. Outro ponto de destaque foi a tentativa de controle das culturas, sobretudo bananais, quase sempre ineficaz, pois a Prefeitura não desenvolveu uma política alternativa de emprego e renda para as famílias que viviam da agricultura nessa região.

No entanto, essa lei foi um instrumento bastante útil, ao trazer, em seu Capítulo XII, instrumento que conferia o poder de polícia administrativa à municipalidade, permitindo a interdição, "em qualquer tempo", de área "considerada suscetível de desmoronamento, comprovado mediante vistoria técnica". 


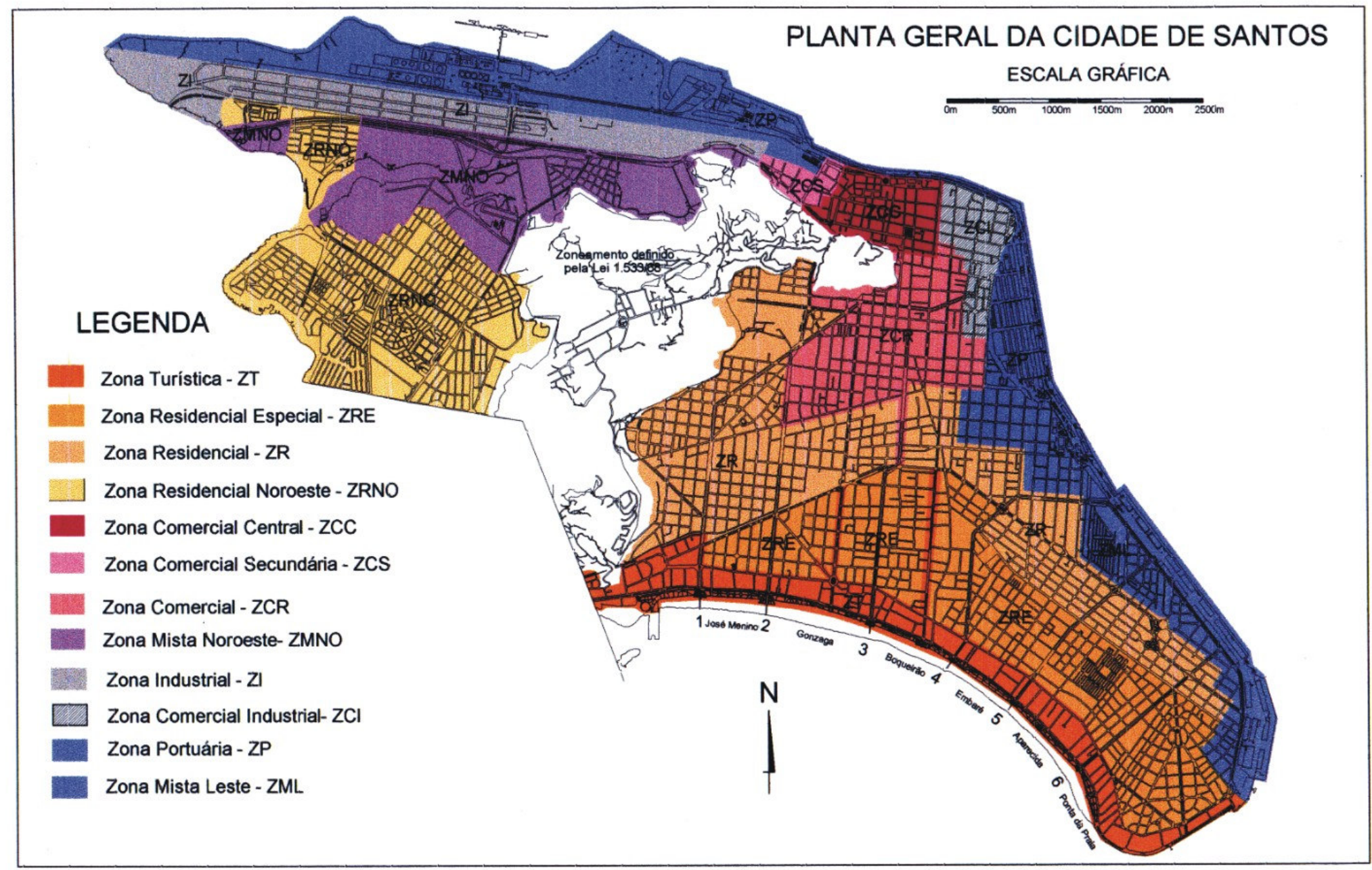


Fechando o Período Desenvolvimentista, já se aproximando do final do milagre econômico, foram elaborados durante a gestão do prefeito Antônio Manoel de Carvalho, os Planos Diretores de Desenvolvimento Integrado de Santos - PDDI Santos, de 1976 e 1978. Pelo primeiro "procurava-se apresentar um quadro do conhecimento da realidade atual e das perspectivas futuras, com vistas a informar a elaboração de referenciais físicos". Pelo segundo, explicitava-se esse referencial de maneira a fornecer diretrizes de âmbito municipal que permitissem "orientar o crescimento físico de Santos e adotar medidas coerentes com as necessidades de seu desenvolvimento".

Os PDDI foram elaborados por uma equipe técnica mista, constituída desde 1975 pela PRODESAN e pelo Grupo 5 Arquitetura e Planejamento - sob orientação dos arquitetos Czaba Deák, Luísa Battaglia e Lenimar Gonçalves Rios, com o auxílio de consultores especiais. A proposta era implantar na cidade um processo contínuo de planejamento, a partir do conhecimento da realidade, da construção de quadros prospectivos, proposta de estratégia de ação, enfrentamento de problemas emergentes e projetos setoriais.

Por meio de uma análise exaustiva de dados, traçava-se um perfil da estrutura urbana de então, buscando atingir objetivos já explicitados desde o PDDI 76. Identificavam-se os efeitos do Plano de 1968, bem como os fenômenos espontâneos, que possuíam forte determinação social.

O PDDI 78 identificava a estrutura urbana da época, explicitada em várias cartas contendo a evolução da ocupação, a tipologia das edificações, uso do solo, rede de centros, estrutura viária, equipamentos urbanos e unidades ambientais. Quanto à estrutura espontânea, a equipe identificava as tendências de crescimento e propunha suas diretrizes. A partir desses dados apresentava-se uma proposta utópica, o que era bastante comum para o planejamento da década de 1970. Nessa proposta estavam contidos os seguintes princípios: uso do solo; reforço das unidades ambientais; preservação do conforto ambiental; reforço do centro histórico; aprimoramento da paisagem urbana; equipamentos urbanos e acessibilidade (ver Mapa à p. 158).

Embora os PDDI não fossem instrumentos legais, neles estava contida uma proposta clara de alteração do uso do solo, de forma a controlar o adensamento nos estudos prospectivos nele contidos, curiosamente superestimado ${ }^{91}$. Da mesma forma propunha-se o controle da "verticalização indiscriminada" e a adoção de critérios de controle da ocupação e urbanização nos morros, os quais vinham sendo estudados paralelamente.

Mas, justamente por ser uma carta de princípios, sem força legal, os PDDI permaneceram como letra morta. Da mesma forma, a legislação em estudo, como conseqüência das conclusões contidas nos PDDI, nunca veio a ser efetivamente encaminhada à Câmara, pelo menos na forma que se pretendia. Pelo que se pode deduzir a partir da leitura das propostas do PDDI 78, esses projetos de lei não tinham afinidades com os interesses reais do setor da promoção imobiliária, que era indiferente ao controle da

91 Ao basear-se na projeção das altas taxas de crescimento demográfico da década de 1970, o trabalho acabou por prever para o final do século passado um adensamento populacional exagerado para Santos, cujas taxas nos anos 90 foram baixíssimas. 
ocupação nos morros e sempre viu com maus olhos as iniciativas visando restringir a verticalização na Zona Leste.

Podemos encontrar em VILLAÇA (1988 e 1998) aprofundadas análises desse tipo de plano, apontando as razões pelas quais nas principais metrópoles do Brasil foi produzida, uma série de planos semelhantes aos PDDI Santos $^{92}$. Foram planos que permaneceram nas gavetas das administrações públicas, contendo exaustivos levantamentos das situações locais e propostas descoladas da realidade, que passavam ao largo da luta contínua por melhores localizações dentro da cidade e sua principal e mais grave conseqüência, a segregação espacial.

Portanto, no Período Desenvolvimentista foram estabelecidas amplas áreas, na região que compreende a orla e a parte intermediária da Zona Leste de Santos, onde era vedado o uso não residencial. Como exceção, criaramse núcleos, geralmente localizados na confluência dos eixos viários mais importantes, onde era permitido uso comercial e de prestação de serviços. No restante da cidade, na maior parte dos morros, Zona Noroeste, Centro e bairros próximos a ele, assim como na área portuária, ficavam permitidos os demais usos.

Com esse zoneamento de cunho eminentemente funcionalista garantiram-se áreas de excelência ambiental dentro da ilha, mais afastadas do Centro e do porto, e com

\footnotetext{
92 VILLAÇA classifica o período do planejamento urbano do Brasil, que vai da década de 1930 a 1990, de período de planos de "eficiência". Ou seja, planos que buscavam preparar a cidade para desempenhar seu papel no contexto do capitalismo periférico. São, no entanto, planos discursivos, desvinculados do debate político e, por esta razão, não operam em nível do real, tal como as leis de zoneamento o fazem.
}

total acessibilidade para as classes dominantes. Para a maior parte da classe média que se estabeleceu nas zonas residenciais, a distância entre a orla e a área central ou o porto - locais de geração de emprego - não era obstáculo, devido à sua mobilidade dada pelo transporte individual. $\mathrm{Ou}$ seja, o transporte acabou por ter um peso menor no orçamento da burguesia do que para as classes de baixa renda.

Para essas classes, além da questão do aumento do valor imobiliário, a questão da mobilidade foi crucial, pois a alternativa foi estabelecer-se em grandes bairros populares nas zonas de uso misto próximas ao porto e ao centro bairros de Vila Nova, Vila Mathias, Macuco, Jabaquara, Estuário, na Zona Noroeste e nos morros, assim como em determinadas áreas de municípios vizinhos. Eram estas a região ao norte da área insular de São Vicente, o distrito de Vicente de Carvalho - antiga Bocaina - em Guarujá e o Casqueiro e a Vila dos Pescadores, em Cubatão.

Dessa forma, ao longo da segunda metade do século, consolidou-se essa divisão espacial da cidade, por classes sociais. A cada nova lei essa divisão foi sendo reforçada, de forma cada vez mais sutil. Conforme as Zonas Residenciais junto à orla foram se adensando, a demanda por comércio e serviço aumentou, exercendo-se grande pressão para que se flexibilizasse a separação entre usos residenciais e não residenciais. A forma encontrada para dar conta dessa contradição foi vincular esses usos não residenciais, extensivos às residências, às vias de maior porte, deixandose as vias locais livres dos "incômodos" do pequeno comércio e dos pequenos prestadores de serviços. 
A maneira como se deu a manutenção de qualidade de vida nas áreas predominantemente habitadas pelas classes de alta renda, e como as camadas populares foram circunscritas às áreas de uso misto, com os inconvenientes da convivência diária com a atividade portuária - tráfego pesado, ruídos, poluição atmosférica, etc., teve relação com a capacidade dessa elite em influir ou, até mesmo, controlar o aparato técnico de planejamento e a classe política da cidade, de forma a legislar em benefício próprio.

Assim, influindo ou controlando o processo de elaboração das diversas legislações urbanísticas, a burguesia sempre soube como se articular e se fazer representar junto aos meios técnicos e políticos da cidade, visando a manutenção de seu status quo. O exemplo mais emblemático talvez seja o da formação dos conselhos de planejamento. Criado pela Lei $\mathrm{N}^{\circ} 2.852$, de 27 de abril de 1964, o primeiro conselho dessa natureza, denominado Conselho Municipal de Planejamento, possuía uma composição bastante representativa das entidades de classe típicas das classes média e alta. Sua atribuição era opinar e propor estudos relativos ao Plano Diretor.

Posteriormente, depois de editado o primeiro Plano Diretor, pela Lei $N^{\circ} 3.529$, de 16 de abril de 1968, o conselho foi consolidado no corpo dessa lei, com a nova denominação de Conselho Consultivo do Plano Diretor - COPLAN, e contando com nova composição, já majoritariamente representante dos interesses da burguesia. $\mathrm{Na}$ verdade, esse conselho, ainda que indiretamente, sempre atuou em favor da manutenção da melhor localização na ilha para as classes sociais de mais alta renda, ainda que de forma sutil.
Foi o COPLAN que criou os maiores obstáculos à aprovação da lei que criou as Zonas Especiais de Interesse Social - ZEIS, Lei Complementar $\mathrm{N}^{\circ} 53$, de 15 de maio de 1992, legislação destinada a implementar os avanços da Constituição Federal de 1988, no âmbito da política urbana. Esta lei visava incentivar especialmente a implantação de projetos habitacionais destinados às classes de baixa renda. A participação predominante de entidades ligadas à promoção imobiliária no COPLAN acabou garantindo, que as áreas objeto da Lei de ZEIS não se localizassem próximas à orla ${ }^{93}$.

Após 1998, já sob a vigência da atual Lei de Ordenamento do Uso e da Ocupação do Solo na Área Insular do Município, Lei $\mathrm{N}^{\circ} 312$, de 23 de novembro de 1998, foi criado o Conselho Municipal de Desenvolvimento Urbano CMDU, uma adaptação do antigo COPLAN, com uma composição que beneficiou igualmente os interesses das classes burguesas na cidade.

Assim, podemos assegurar que a manutenção da melhor localização na cidade pelas classes de mais alta renda, tal como nas demais metrópoles brasileiras, deu-se através do domínio da política e da técnica. Essas classes fizeram-se sempre valer de um aparato ideológico, que foi se transformando e adaptando ao longo do tempo. Esse aparato constituiu-se na utilização de premissas indiscutíveis como sanitarismo, qualidade de vida, meio ambiente, etc., para atingir fins bastante discutíveis, ou seja, a segregação de espaços no território da cidade.

\footnotetext{
${ }_{93}$ Para um estudo mais aprofundado desse processo recomendamos a
} leitura de CARVALHO (1999). 
Como lembrou BONDUKI (1998: 321), "Finalmente, ainda caracteriza este modelo uma excessiva e muitas vezes inócua regulamentação do uso do solo via legislação urbanística, formulada em geral em gabinetes, sem participação dos moradores. Sustentada por uma suposta racionalidade, conveniente em períodos de autoritarismo, esta regulamentação tem se tornado letra morta mas serviu de retórica para mostrar um poder público supostamente preocupado e interveniente em relação à questão urbana". Pode-se concordar, quase inteiramente com essa crítica à legislação urbanística, porém, vale ressaltar, no tocante à sua capacidade de garantir territórios de exclusão em nossas metrópoles, que essas leis têm sido bastante "úteis" e de maneira alguma têm se constituído em "letra morta".

Tabela 16

\section{Santos - Legislação urbanística principal do período} desenvolvimentista

\begin{tabular}{|l|r|r|l|}
\hline \multicolumn{1}{|c|}{ Tipo } & $\mathbf{N}^{\circ}$ & \multicolumn{1}{c|}{ Data } & \multicolumn{2}{|c|}{ Nome } \\
\hline Dec.-Lei & 403 & $15 / 09 / 1945$ & Código de Obras \\
\hline Lei & 1.316 & $27 / 12 / 1951$ & $\begin{array}{l}\text { Plano Regulador de Expansão e } \\
\text { Desenvolvimento }\end{array}$ \\
\hline Lei & 1.831 & $09 / 05 / 1956$ & $\begin{array}{l}\text { Alteração do zoneamento do Código de } \\
\text { Obras de 1945 }\end{array}$ \\
\hline Lei & 3.529 & $16 / 04 / 1968$ & Plano Diretor Físico do Município \\
\hline Lei & 3.530 & $16 / 04 / 1968$ & Código de Edificações do Município \\
\hline Lei & 3.531 & $16 / 04 / 1968$ & Código de Posturas do Município \\
\hline Lei & 3.533 & $16 / 04 / 1968$ & $\begin{array}{l}\text { Normas Ordenadoras e Disciplinadoras } \\
\text { dos Morros }\end{array}$ \\
\hline Lei & 4.078 & $03 / 12 / 76$ & $\begin{array}{l}\text { Código de Uso e Proteção do Distrito de } \\
\text { Bertioga }\end{array}$ \\
\hline
\end{tabular}




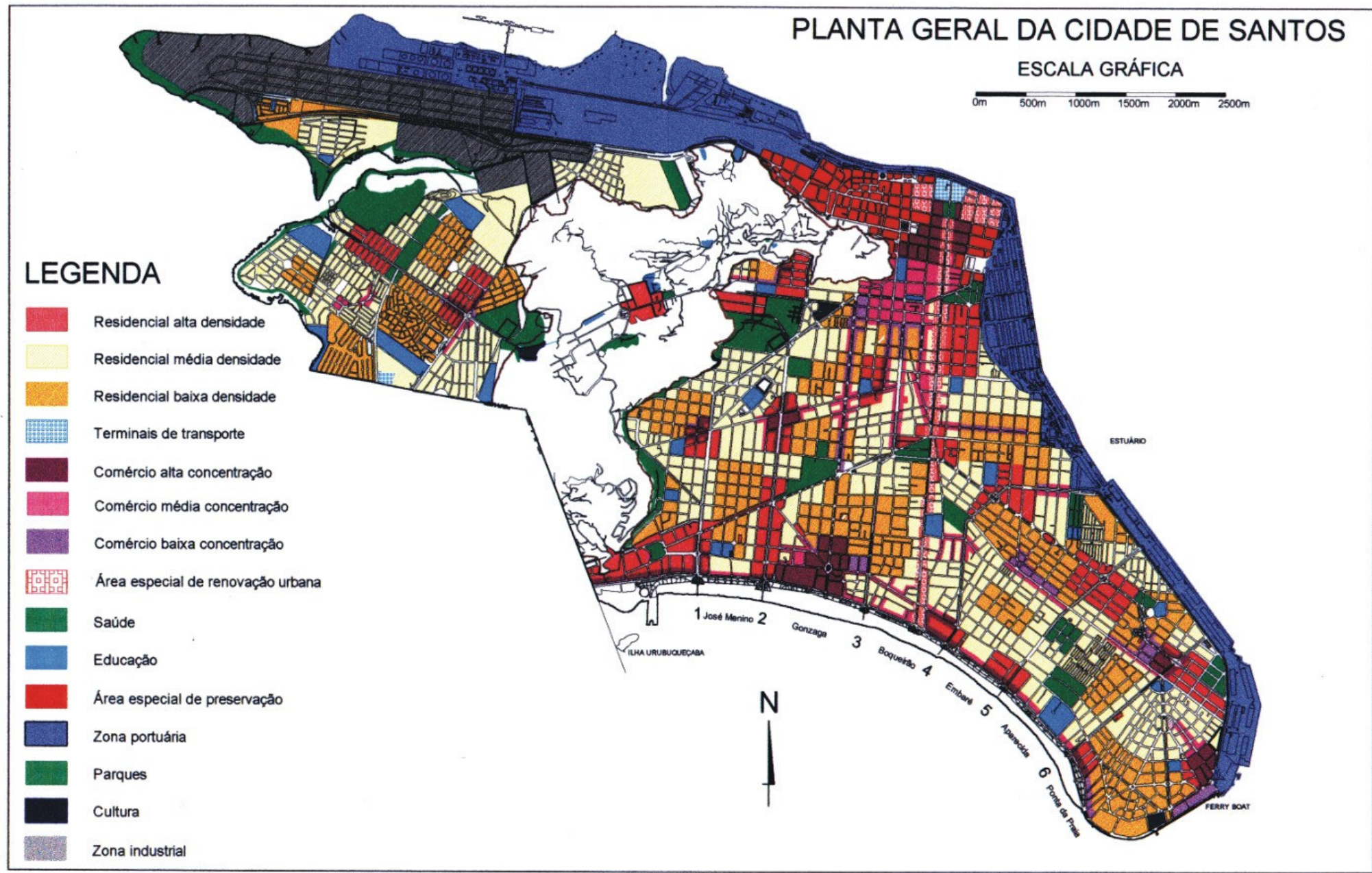




\subsubsection{Considerações sobre a evolução da regulação urbanística em Santos}

Refletindo-se sobre as questões abordadas anteriormente, deve-se destacar alguns fatos. Em primeiro lugar, o discurso sanitarista baseado na necessidade de erradicar as epidemias, no final do século XIX, foi apropriado pelas classes dominantes, com o objetivo de criar zonas de exclusão social na cidade. Nestas áreas concentraram-se os investimentos públicos, mantendo uma razoável oferta de infra-estrutura e serviços.

A princípio, utilizou-se a violência explícita, removendo-se cortiços e chalés das áreas consideradas "nobres". Posteriormente, o processo tornou-se mais sofisticado, utilizando-se a legislação urbanística como forma de garantir a exclusividade em determinadas áreas, consideradas de melhor localização pelas classes de alta renda, para nelas concentrar a maior parte dos investimentos públicos em manutenção e melhorias urbanas.

A forma como se deu a apropriação da legislação urbanística pelos interesses imobiliários pode ser lida nas entrelinhas das várias leis que estiveram em vigor no último século. Pode-se destacar, especialmente, alguns fatores introduzidos pela legislação urbanística ao longo do século $\mathrm{XX}$, como responsáveis pelo processo de valorização imobiliária das áreas objeto desses instrumentos.

São alguns destes a introdução da figura do lote mínimo, em 1945, e a exigente e sistemática regulamentação do chalé de madeira e outras modalidades de moradia popular, estabelecida por leis que dificultaram ou segregaram os chalés, a partir do final do século XIX, como foi o caso do Código de Posturas, de 1897 e da Lei N460, de 1911.

O primeiro fator foi um dos principais obstáculos ao parcelamento do solo urbano em condições mais acessíveis à população de baixa renda. Essa limitação foi extremamente exagerada para uma cidade insular, com área reduzida, impelindo aos poucos a população pobre a buscar moradia nos morros, manguezais, várzeas inundáveis ou na outra margem do estuário. O segundo representou o cerceamento ao acesso à moradia dentro das condições possíveis para essa população, em determinadas áreas da cidade, contribuindo também para a segregação de territórios por nível de renda.

Em vários dos instrumentos urbanísticos analisados também podemos encontrar outros tipos de restrições às edificações de baixo custo, seja por meio de índices urbanísticos limitadores do adensamento, seja por meio de exigências de utilização de determinados materiais e padrões de construção, ou mesmo pelo estabelecimento de dimensões mínimas de cômodos para as moradias.

$\mathrm{Na}$ segunda metade do século $X X$, quando a tecnologia possibilitou o adensamento pela verticalização, colocando no mercado imóveis acessíveis apenas às classes de média e alta renda, o discurso contra o adensamento adaptou-se, e com ele as restrições urbanísticas, como a limitação do gabarito dos edifícios, por exemplo. Esta limitação nunca impediu que o setor da produção imobiliária tirasse da terra o maior rendimento possível. Isso permitiu que a região mais próxima da orla marítima fosse extremamente adensada, comprometendo a balneabilidade das praias. Essa tendência estendeu-se às áreas intermediárias da 
Zona Leste da cidade, provocando a substituição paulatina da cidade horizontal pela vertical e mantém-se até os dias de hoje.

Cabe ressaltar que a Baixada Santista possui um solo extremamente frágil, a argila marinha, que traz grandes obstáculos à verticalização. Isso resulta em investimentos muito elevados em fundações, para que se possam construir edifícios acima de três pavimentos. Há áreas em Santos e municípios vizinhos em que a camada impenetrável de solo encontra-se a mais de 60 metros de profundidade, razão pela qual a cidade é conhecida pelos edifícios em desaprumo da orla marítima, construídos na época em que as fundações diretas ainda não eram utilizadas. Isso inviabilizou a construção de habitações populares mais verticalizadas e, ao mesmo tempo, pode ter contribuido para a restrição da ocupação da orla marítima à população flutuante e às classes de alta renda.

Exceção deve ser feita em relação a edifícios de apartamentos tipo quarto e sala conjugados, conhecidos no mercado como kitchenetes, quase todos construídos na orla, entre as décadas de 50 e 70 , os quais sofreram um parcial processo de substituição de população flutuante, por população de classe média residente no município, como podemos observar em SEABRA (1976).

De qualquer forma, vale ressaltar que as classes de alta renda apropriaram-se do discurso em defesa da limitação à verticalização, justificando, a partir de questões ambientais e de segurança - comprovadamente existentes - a manutenção de um certo padrão de construções inacessível às parcelas de baixa renda, na Zona Leste da cidade,. O mesmo discurso tem sido adaptado no período atual pelas mesmas classes, revestido de zelo "ambiental", para garantir territórios exclusivamente ocupáveis, na cidade de Santos.

Posteriormente, a proibição da construção de moradias no centro da cidade, a partir do Plano Diretor Físico de 1968, excluiu das possibilidades de acesso para a população de baixa renda uma área dotada de infra-estrutura urbana semi-ociosa e de excelente localização, contribuindo para a redução do leque de opções de localização, dentro do mercado formal, desta parcela da sociedade.

Por outro lado, a deficiência ou mesmo a inexistência de políticas públicas habitacionais voltadas para as populações de baixa renda, aliada à fiscalização leniente, bem como à fragilidade das regras para impedir a ocupação das áreas ambientalmente mais frágeis ou inseguras, quanto aos aspectos sanitários ou geológicos, propiciaram uma ocupação desordenada do território da RMBS.

A busca de localizações, pelos que não conseguiram ter acesso às moradias nas áreas mais "nobres", próximas aos pólos geradores de emprego e renda, levou à ocupação de encostas, manguezais e a sobrevivência dos cortiços como alternativa habitacional.

Ao mesmo tempo, nos municípios vizinhos a Santos, especialmente São Vicente, Cubatão e Guarujá, onde a legislação atuou de forma semelhante, como será visto no item 4.2., havia uma grande oferta de áreas impróprias à ocupação. Como o controle da ocupação dessas áreas também foi deficiente nesses municípios, a RMBS foi objeto, sobretudo após o segundo ciclo de industrialização de São Paulo, nas décadas de 50 a 70, de uma explosão no 
número de favelas, parcelamentos irregulares e habitações em morros, várzeas e manguezais. Essas áreas passaram, então, a abrigar a quase totalidade da população de baixa renda que trabalhava no porto, indústrias de Cubatão, na construção civil voltada para o turismo balneário ou no setor terciário.

Questão relevante é a da abrangência da legislação de controle do uso dos territórios dos municípios da RMBS. Ao mesmo tempo em que as áreas com maior oferta de infraestrutura eram super regulamentadas, a periferia das áreas efetivamente ocupadas pela alta e média renda das cidades era delimitada como zona suburbana, de transição ou rural, onde o nível de regulamentação era sensivelmente inferior. Afinal, era necessário para a burguesia, que a população de baixa renda não ocupasse as suas áreas de exclusividade.

Basta lembrarmos que o Código de 1945 destinava aos morros o papel de abrigar as moradias do tipo econômico e chalés, e que foi apenas em 1968, com a sanção da lei $\mathrm{N}^{\circ}$ 3.533, que essa região de Santos foi objeto do estabelecimento de algum critério de ocupação, mesmo assim em nada semelhante ao utilizado na Zona Leste da cidade. É importante dizer que, somente no atual período, após a aprovação da lei de uso do solo que está em vigor ${ }^{94}$, os morros possuem, pela primeira vez na história, critérios de ocupação estabelecidos por lei municipal, equivalentes aos utilizados na parte baixa da cidade.

A questão que queremos levantar a partir dessas constatações, é que por não se dispor de critérios definidos para a ocupação dessas áreas, principalmente no caso dos morros, manguezais e várzeas, as mesmas foram alvo mais fácil de uma forma extremamente predatória de ocupação, que se reproduziu nos demais municípios centrais da região, tal como ocorreu com as áreas de proteção aos mananciais da RMSP.

É necessário lembrar, ainda, que a questão da habitação para as classes populares vem freqüentando a agenda das administrações municipais, estaduais e federais, de uma forma retórica, desde o final do século XIX. Se a princípio a questão era tratada como caso de polícia, em determinados períodos formularam-se políticas mais efetivas para tratar o problema.

Ao longo do século $X X$ pudemos verificar que o tema foi abordado de várias maneiras. Primeiro foram os familistérios e loteamentos populares que não vingaram como alternativa para as classes de baixa renda. Depois foram os grandes conjuntos habitacionais, desde a Fundação da Casa Popular e Institutos de Aposentadoria e Pensão (BONDUKI, 1998: 124 e 151), até o BNH e COHAB-St, que acabaram por gerar áreas de segregação social e má qualidade de vida para essas classes, durante o período da ditadura militar.

Na Baixada Santista, também é possível apontar alguns projetos pioneiros de regularização fundiária, como o da Areia Branca e Vila Ogarita - na Ponta da Praia, em Santos, ou Pae-Cará e Vila Zilda, em Guarujá, que embora tenham obtido algum êxito, ocorreram em número sempre insuficiente para as reais dimensões do problema habitacional.

\footnotetext{
${ }^{94}$ Lei Complementar $N^{\circ} 312$, de 23 de novembro de 1998.
} 
No entanto, após a promulgação da Constituição Federal de 1988, a aprovação e implementação, a partir de 1992, da Lei Complementar $N^{\circ} 53$, que criou as Zonas Especiais de Interesse Social - ZEIS - em Santos, representou uma tentativa de enfrentamento da questão, por meio do estabelecimento de dispositivos urbanísticos capazes de rebaixar o custo do acesso à habitação para a população de baixa renda, em determinadas áreas da cidade.

Ainda é muito cedo para avaliar a eficácia dessa lei, porém vários projetos foram implementados à luz da lei de ZEIS, na cidade de Santos, na década de 1990. O que se pode observar, no entanto, é que um número significativo de famílias que acessaram unidades habitacionais em projetos em ZEIS está negociando, irregularmente, suas unidades, e retornando às condições anteriores e precárias de moradia.

Tal fato ressalta a questão da reprodução da força de trabalho no Brasil do século XX, tão bem apontada em MARICATO (1996: 39-49), que denominou o processo, numa primeira etapa, de "industrialização com baixos salários" e, posteriormente de "modernização excludente"95. Isto é, no sistema capitalista, em vigor no país, desde a abolição da escravatura, a baixa renda do trabalho assalariado nunca garantiu o acesso a condições dignas de

95 Segundo MARICATO, "A industrialização brasileira, que se afirma decisivamente a partir da chamada Revolução de 1930, combinou crescimento urbano industrial com regimes arcaicos de produção agrícola. Um 'pacto estrutural' entre antigos proprietários rurais e a burguesia urbana garantiu mudanças sem rupturas e a convivência de políticas contraditórias". Mais adiante, a autora completou: "Nossas pesquisas mostram que até o trabalhador da industria fordista é levado freqüentemente a morar em favelas, já que nem os salários pagos pela indústria e nem as políticas públicas de habitação são suficientes para atender as necessidades de moradias regulares, legais". moradia, transporte, alimentação e demais itens essenciais de subsistência, para a imensa maioria da população.

Segundo BONDUKI, (1998: 53), citando o Boletim do Departamento Estadual do Trabalho de 1916 (p. 146), "Na classe pobre, especialmente na classe operária, o aluguel da casa absorve uma boa parte dos limitados ganhos do chefe de família. A exigüidade do salário, comum às grandes indústrias (...) põe o operário entre as portas de um angustioso problema: ou comer pouco e mal, ou morar num cortiço. Em nove casos sobre dez, ele opta pela segunda solução. Obedece ao estômago".

Também em BONDUKI (1998: 296) pode-se ler que, “(...) os investimentos na cidade oficial e na criação de uma infraestrutura para a expansão industrial, assim como as altas taxas de acumulação da economia paulista, só foram possíveis graças ao abandono da periferia e à redução do custo de reprodução da força de trabalho, obtida por meio de expedientes como o congelamento dos aluguéis e a produção doméstica da moradia". Dessa forma, quando o trabalhador tem acesso a uma "mercadoria" em potencial, como é o caso da moradia, torna-se irresistível o apelo à venda desse bem, ainda que na maioria dos programas habitacionais seja vedada a alienação a terceiros destas unidades, como é o caso dos programas apoiados na Lei de ZEIS, em Santos.

Portanto, podemos afirmar que a questão da habitação está atrelada à política macroeconômica, a qual, em última análise, é a que determina a capacidade do cidadão permanecer ou não vivendo em condições minimamente aceitáveis. Assim, a Lei de ZEIS de Santos e demais leis urbanísticas de cunho social, que passaram a ser 
implementadas em várias cidades brasileiras, após 1988, não são capazes de permitir isoladamente o enfrentamento das causas desse processo, que conduz à exclusão em nossas metrópoles.

Porém, são essas as formas que estão sendo utilizadas por administrações progressistas, para enfrentar a questão da segregação espacial, na última década. Isso é inovador, mas ainda insuficiente para alterar de maneira significativa o quadro extremamente grave da falta de condições de habitabilidade em nossas metrópoles, nessa virada de século, pois a questão de fundo é a forma como se dá a reprodução da força de trabalho. 


\subsection{A regulação urbanística nos demais municípios} centrais da RMBS

Metodologicamente, é importante ressaltar que, de forma distinta da que foi abordada a legislação urbanística de Santos, proceder-se-á à análise do conjunto da legislação dos demais municípios centrais da RMBS de maneira menos detalhada. Optou-se por esse caminho por duas razões. A primeira se deve ao fato de que, por implicações históricas, esses municípios não contam com uma regulação urbanística em igual magnitude e detalhamento.

Os territórios de Guarujá e Cubatão, em determinados períodos, pertenceram a Santos e sob suas leis foram administrados. São Vicente, embora seja um município mais antigo que Santos, sofreu um processo de estagnação mais longo, o que talvez explique o fato de sua legislação urbanística ter-se consolidado apenas na década de 1950.

A segunda razão, e a mais relevante, é que ao analisar essa legislação, procurar-se-á nela identificar indicadores de processos de exclusão espacial das populações de baixa renda, que guardem similitude e raízes comuns aos processos correlatos verificados em Santos e, de alguma maneira, tenham contribuído para reforçar o processo excludente na cidade pólo regional.

No entanto, para tal fim não será necessário o mesmo grau de aprofundamento na legislação urbanística desses municípios, sendo suficiente proceder-se à análise da legislação urbanística mais importante, ou seja, dos códigos e planos aprovados durante o século $X X$, até o final do período desenvolvimentista. 


\subsubsection{A regulação urbanística em São Vicente}

Antes de procedermos à análise da legislação urbanística de São Vicente, é necessário tecer algumas considerações, que poderão colaborar na compreensão de sua elaboração e aplicabilidade ao longo do tempo, sobretudo na segunda metade do século $\mathrm{XX}$, quando sua área insular passou a ser totalmente ocupada.

O município de São Vicente tem atualmete área total de 146 $\mathrm{Km}^{2}$ e guarda certa similitude com o de Santos, pois tal como este tem sua sede dividindo o espaço da llha de São Vicente e possui uma vasta área continental, que até 1963 abrangia o território do município de Praia Grande, ao sul. Mesmo com a autonomia deste último município, São Vicente manteve uma área continental de dimensões significativas.

Hoje, o município de São Vicente distribui-se em área insular, com $18 \mathrm{Km}^{2}$ e área continental, dividida em várias porções, totalizando $117 \mathrm{Km}^{2}$ da seguinte forma: Bairro do Japuí, com $3 \mathrm{Km}^{2}$; Planície de Samaritá, com $37 \mathrm{Km}^{2}$ e o restante dividido entre a Zona Rural, no sopé da Serra do Mar, a área de preservação da Serra do Mar e áreas de rios, canais, praias e costões junto ao Parque Estadual Xixová-Japuí, na divisa com o município de Praia Grande (ver Figura 33).

No entanto, as semelhanças terminam por aí. Ao contrário de Santos, que possui uma grande planície entre o centro e a orla marítima, a qual passou a ser ocupada após a implantação do plano de saneamento e drenagem de Saturnino de Brito, São Vicente possui uma área ocupável muito restrita, junto à sua orla (ver Figura 34).

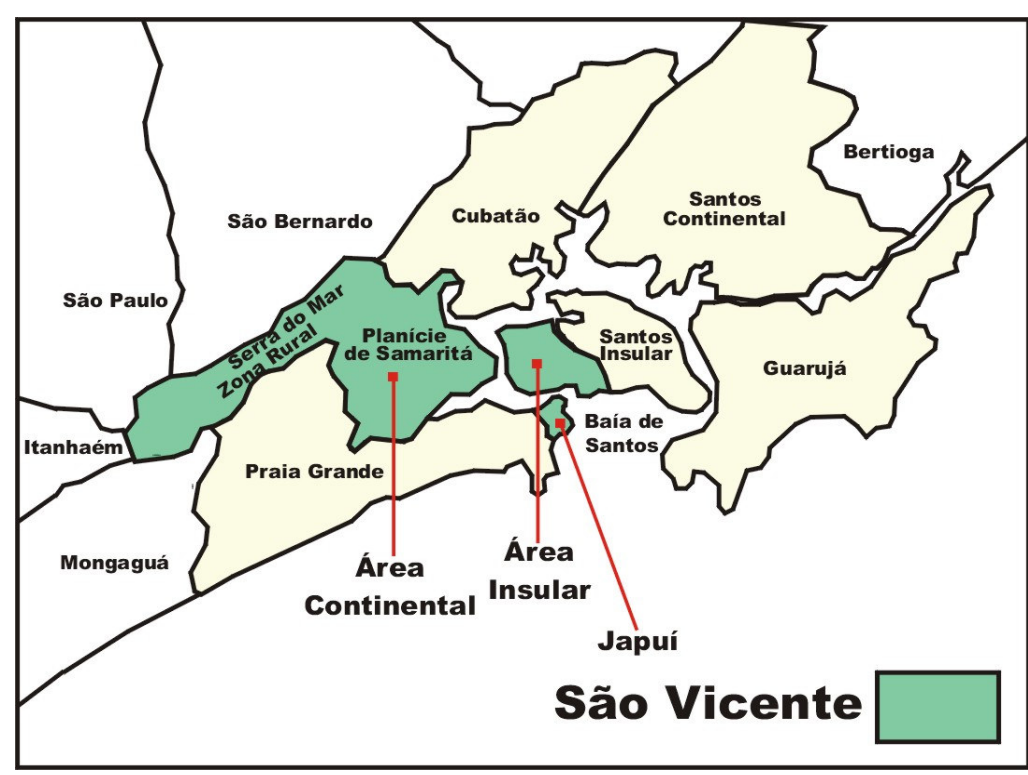

Figura 33 - Divisão de São Vicente em áreas. Fonte: Prefeitura Municipal de São Vicente.

Assim, o processo de verticalização ao longo da orla, que ocorreu concomitantemente ao de Santos, a partir da década de 1950, não produziu número comparável de imóveis de veraneio, nem posteriormente houve processo de ocupação dos mesmos pela burguesia vicentina, na mesma medida em que se deu em Santos.

Uma resultantea dessa limitação territorial é que a proximidade do centro da cidade com a orla é grande, o que a nosso ver impediu a formação de um segundo centro comercial e de serviços, tal como ocorreu em Santos no bairro do Gonzaga. 
Outro fator importante é que a maior parte da área insular vicentina está situada "atrás" do maciço central de morros e da ferrovia, em áreas menos valorizadas turisticamente, o que possibilitou o estabelecimento ali de uma numerosa população de baixa renda, cujo vínculo em termos de trabalho é maior com os municípios de Santos e Cubatão, em função do Porto, do setor terciário santista ser mais expressivo e do Parque Industrial cubatense.

Vale ressaltar que diferentemente do caso de Santos, em função de seu relevo íngreme, os morros de São Vicente não foram ocupados pela população de baixa renda, à exceção das áreas próximas à divisa com o primeiro município, onde as ocupações ocorreram, na verdade, como conseqüência do estabelecimento de assentamentos populares do lado santista. No entanto, principalmente após a década de 60 , a franja de manguezal à oeste e ao norte da área insular foi ocupada por favelas e parcelamentos de baixa renda. Segundo dados da FIBGE, referentes ao ano de 1982, a população vicentina em submoradias era de 17.889 habitantes (SERRANO, 1991: 34).

Cabe ainda destacar que a outra parcela da área a ser ocupada pelas classes populares, em São Vicente, foi sua área continental, na Planície de Samaritá e, em menor grau, no Bairro do Japuí. Isso se deu, sobretudo a partir da década de 60 , quando vários loteamentos passaram a ser implantados fora da área insular. A área continental vicentina, ao contrário da santista, foi conquistando com o passar do tempo maior facilidade de acesso, em relação à sede do município e à llha de São Vicente, em geral.

Quanto à área continental de Santos, o porto tornou-se um obstáculo à ligação rodoviária e, conseqüentemente, à sua ocupação intensiva. Tal distinção certamente é marcante, pois no caso de Santos a área continental nunca se constituiu numa alternativa habitacional significativa, para a população de baixa renda.

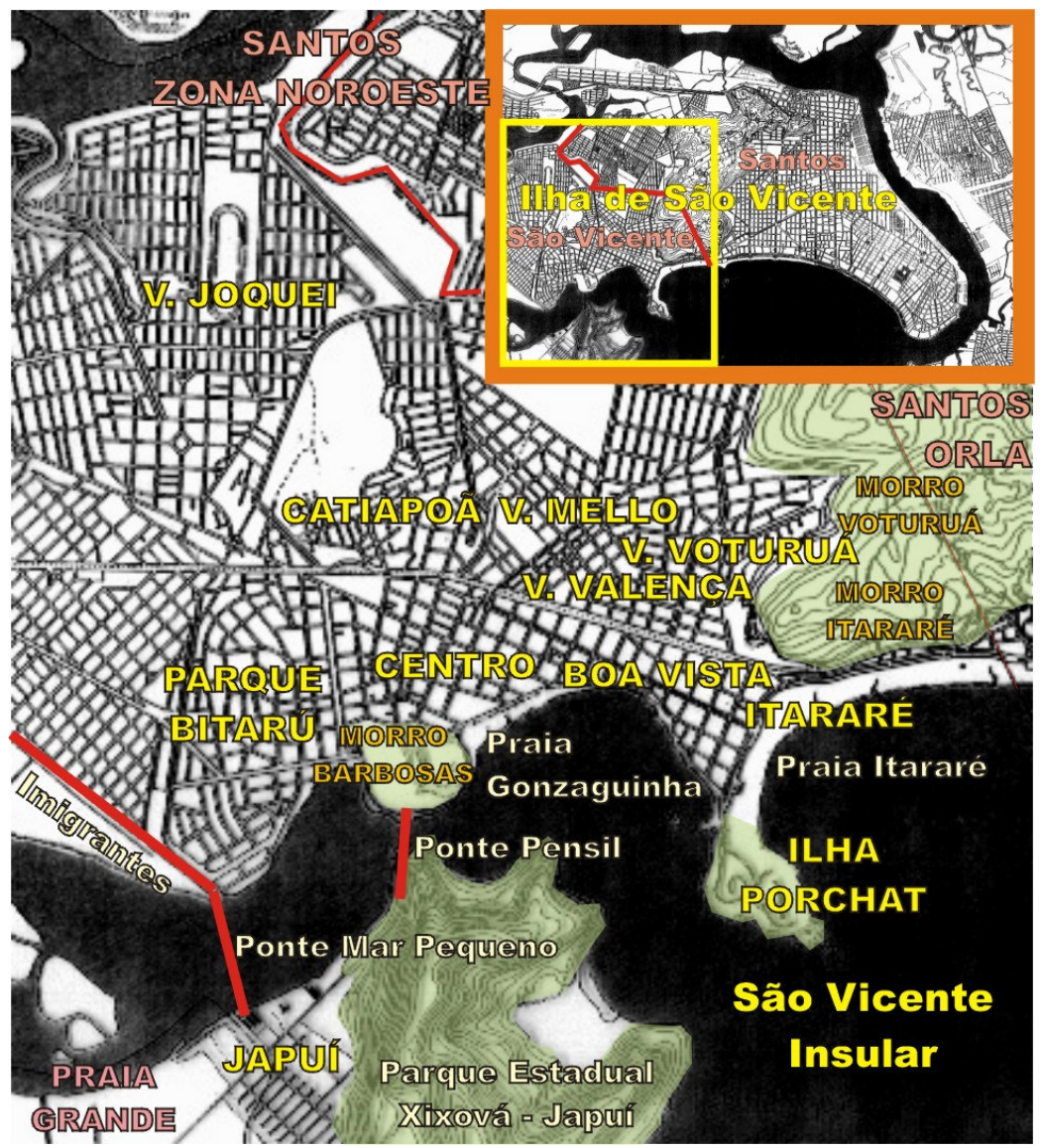

Figura 34 - Abairramento da Área Insular do Município de São Vicente e bairro do Japuí, na área continental. 
A princípio a ligação entre a ilha e a Planície de Samaritá dava-se por via ferroviária, pelo ramal da Estrada de Ferro Sorocabana - depois operado pela FEPASA e atualmente pela CPTM. Não por acaso o primeiro núcleo popular na Planície de Samaritá formou-se próximo à estação ferroviária de mesmo nome.

Com a construção da rodovia Cubatão-Pedro Taques, que distribui o trânsito do Sistema Anchieta-Imigrantes para o Litoral Sul do Estado de São Paulo, a Planície de Samaritá tornou-se acessível, também via rodoviária, através do município de Cubatão. Atualmente esse acesso tornou-se mais facilitado, pois a Planície encontra-se ligada à sede do município pela ponte Jornal A Tribuna - também conhecida como ponte dos Barreiros (ver Figura 35).

Segundo resultados do Censo Demográfico da FIBGE, de 1991, a população vicentina distribuía-se assim: Área Insular, 221.296 habitantes; Bairro do Japuí, 4.884 habitantes; Planície de Samaritá, 42.287 habitantes; e zona rural somada às áreas de preservação, 265 habitantes. Portanto, no princípio da década de 90 , quase $16 \%$ da população vicentina já habitava a Planície de Samaritá, a qual, após a inauguração da ponte Jornal A Tribuna, consolidou-se como alternativa de habitação popular, em função do valor imobiliário acessível dos lotes lá negociados.

Segundo estimativa atual da Prefeitura Municipal - que ainda aguarda que os resultados do Censo Demográfico 2001, por setor censitário, sejam transformados em dados por bairros - a planície de Samaritá já possui cerca de 70.000 habitantes. Tal estimativa demonstra uma explosão da ocupação da área continental de São Vicente durante a última década.

Por fim, outro aspecto relevante a destacar é o ritmo de ocupação do território vicentino que se diferenciou muito do de Santos. São Vicente foi fundada pelo nobre português, Martim Afonso de Souza, em 22 de janeiro de 1.532, portanto, treze anos antes que Santos. Sete meses mais tarde Martim Afonso fez realizar as primeiras eleições das Américas, instalando a primeira câmara de vereadores do continente.

No entanto, por razões de segurança, as embarcações que lá fundeavam, passaram a atracar no lagamar de Enguaguaçú, onde se fundou o povoado de Santos, na divisa atual dos bairros Centro e Paquetá. Esse fato trouxe rápido declínio e estagnação a São Vicente, que ficou praticamente restrita a sua atual área central até meados do século $X X$. O impulso à expansão da ocupação do território do município, a partir de então, foi decorrente do processo de industrialização da RMBS e da intensificação do turismo balneário, possibilitado pela abertura da Via Anchieta. 


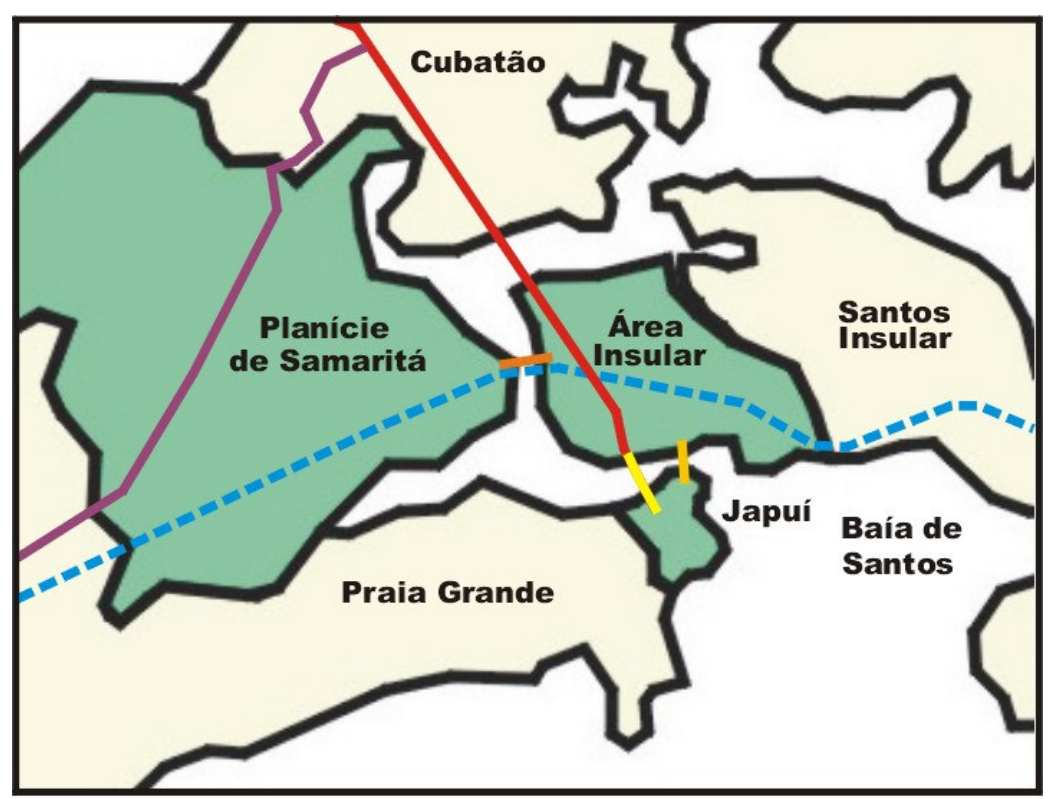

\section{Legenda}

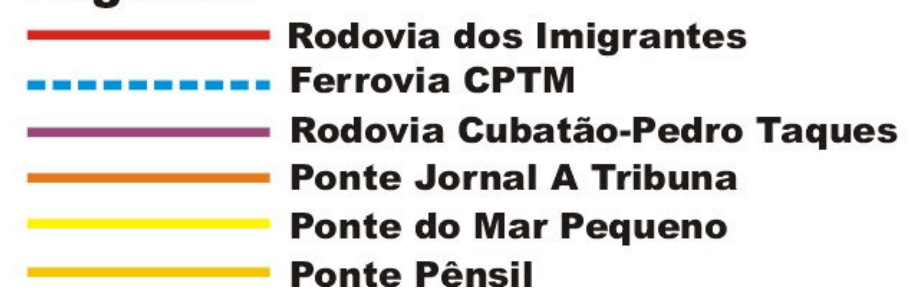

Figura 35 - Principais acessos à São Vicente, segundo suas áreas.

Em poucas décadas o restante da área insular do Município foi ocupada por milhares de habitantes com vínculo de trabalho nos municípios de Santos, Cubatão e na construção civil da orla vicentina. Posteriormente, a área continental de São Vicente passou a ser ocupada, em processo que atingiu seu ápice nos anos 90.

\subsubsection{Análise da legislação urbanística de São Vicente}

Dentre os principais instrumentos legais da regulamentação urbanística do município de São Vicente, objetivou-se o estudo das principais leis vigentes durante o século $X X$, ou seja, as leis № 406, de $1^{\circ}$ de setembro de 1956 - Código de Obras do Município de São Vicente, a № 2.025, de 9 de julho de 1985 - que estabeleceu normas para ordenar e disciplinar a ocupação do território do Município e uso do solo da área insular, a № 2061 de 1986, que definiu e delimitou as Zonas Urbanas, Zonas Especiais, Zonas de Preservação Ambiental e Zona Rural da Área de Samaritá, uso do solo da área continental.

O Plano Diretor em vigor, Lei Complementar $\mathrm{N}^{\circ} 270$, de 29 de dezembro de 1999, não foi objeto de análise, por não estar inserido nos limites do período metodologicamente escolhido para esta pesquisa.

Procurou-se focalizar os principais elementos contidos nessa legislação que contribuíram para a segregação da população de baixa renda, em áreas do município afastadas do centro e desprovidas do mesmo nível de oferta de serviços e infra-estrutura urbana.

Até que entrasse em vigor o Código de Obras, de 1956, a regulação urbanística do município de São Vicente era esparsa, composta de várias leis que abordavam aspectos isolados como arruamento e normas edilícias, por exemplo. Anteriormente, só existiam normas incipientes de controle do uso e ocupação do solo, sem contudo haver um 
zoneamento de uso tipicamente funcionalista, o que só veio a ocorrer em 1956, motivo pelo qual iniciaremos a análise pelo referido Código de Obras.

O Código de 1956 foi elaborado por uma comissão criada, no âmbito da Municipalidade, pelo engenheiro Rafael Faro Politi, em 1955. Provavelmente a elaboração do código neste momento adveio da necessidade de controlar o crescimento da cidade, que já estava a exigir uma regulação mais efetiva.

As três primeiras partes do Código de Obras do Município de São Vicente, de 1956, são dedicadas à regulamentação da construção de edificações. Podemos destacar o Título VII - artigos 66 a 73 - em que se estabeleceram restrições à construção de vilas, conjuntos de edificações tipicamente populares, vedando-se suas construções nas "Zona Comercial, 1a Zona Residencial, largos e praças".

Limitava-se também a dimensão da frente das residências em vilas ao mínimo de $6 \mathrm{~m}$, bem como o número máximo de construções geminadas a cinco. O recuo frontal mínimo admitido deveria ser de $3 \mathrm{~m}$.

O Título VI, na Segunda Parte, tratava das construções expeditas, sendo que os artigos 165 a 168 tratavam das casas de madeira, que acabaram por ter sua construção admitida tão somente na Zona Rural e 3믈 Zona Residencial. Tal como a legislação santista do período, além das precauções de inspiração sanitária, havia uma preocupação com a questão dos incêndios. Por isso, os recuos destas edificações deveriam ser de $2 \mathrm{~m}$, em relação à divisa lateral dos lotes.
As moradias de madeira edificadas anteriormente ao Código poderiam vir a ser regularizadas, desde que respeitassem os requisitos nele estabelecidos e servissem de residência aos seus proprietários. Dessa forma procurava-se se obstaculizar a construção de habitações de madeiras com finalidade rentista.

Certamente tais restrições, juntamente com a exigência de que as moradias de madeira possuíssem compartimentos de permanência prolongada com área mínima de $10 \mathrm{~m}^{2}$, entre outras, podem ter contribuído para a menor ocorrência da construção dos chalés em áreas mais "nobres" de São Vicente.

A quarta Parte do Código - artigos 415 a 462 - tratava dos critérios para implantação de loteamentos. A quinta Parte tratava do abastecimento de água, águas pluviais, sistemas de esgoto e resíduos sólidos. A sexta Parte era dedicada ao saneamento na Zona Rural.

A sétima Parte - artigos 532 a 557 - era dedicada ao Zoneamento de uso e ocupação do solo. Eram estabelecidas cinco zonas: Zona Comercial - ZC, $1^{\text {a }}$ Zona Residencial - 1ㄹ $\mathrm{ZR}, 2^{\underline{a}}$ Zona Residencial $-2^{\underline{a}}$ ZR, $3^{\text {a }}$ Zona Residencial - 3 ZR, e Zona Rural.

A Zona Comercial era dividida em duas glebas: a gleba do perímetro urbano e a de Praia Grande. A primeira correspondia à área mais central da São Vicente de hoje, contida entre a via férrea, o eixo da rua Frei Gaspar e o eixo da rua XV de Novembro. A segunda correspondia à área comercial do Boqueirão da Praia Grande atual. 
A 1a ZR, também foi dividida em duas glebas. A primeira correspondia, aproximadamente aos bairros Gonzaguinha, Boa Vista e Itararé, ou seja, a área da orla marítima, entre o maciço de morros e a ferrovia, onde ocorreu processo de adensamento com verticalização similar à orla de Santos. A segunda correspondia à orla marítima do Boqueirão de Praia Grande, até o Canto do Forte do Itaipu, limitando com o maciço de morros do Xixová, junto ao bairro continental vicentino do Japuí.

A $2^{\mathrm{a}} \mathrm{ZR}$ foi dividida em três glebas. A primeira correspondia à área do centro inscrita em um polígono limitado pelo eixo da rua XV de Novembro, até a rua Bento Viana, no Parque Bitarú, na direção leste-oeste; bem como pela linha férrea até o edifício do Corpo de Bombeiros, na direção norte-sul. A segunda gleba correspondia, aproximadamente aos bairros Vila Valença, Vila Voturuá e Independência, entre a av. Antônio Emmerich e o sopé do morro Voturuá. A terceira gleba correspondia à área do Boqueirão em Praia Grande mais afastada da orla marítima, limitada ao norte pela "Estrada de Rodagem do Litoral Sul".

A $3^{\text {a }}$ ZR era a parcela do perímetro urbano não contida nas demais zonas, na área insular de São Vicente. A Zona Rural era todo o restante do território do município vicentino de então, que incorporava ainda o restante do território de Praia Grande.

Se compararmos o Código de Obras de São Vicente ao Decreto-Lei $N^{\circ} 403$, de 1945, que estabelecia o zoneamento no município de Santos, quase uma década antes, pode-se verificar que o primeiro não possuía um rigor tão exacerbado no tocante à restrição de usos, segundo suas zonas. No entanto, o Código de Obras direcionou coerentemente o uso residencial às Zonas de mesmo nome, embora nestas áreas fossem admitidas atividades comerciais e de prestação de serviços de baixo impacto. $\mathrm{Na}$ Zona Comercial era admitido o uso habitacional e as indústrias pesadas eram impedidas de se estabelecer.

Quanto às dimensões das edificações, na Zona Comercial a altura das edificações era limitada ao dobro da largura do logradouro em que se situassem. Não era estabelecida taxa de ocupação mínima e os recuos mínimos exigidos eram de $3 \mathrm{~m}$ nos fundos dos lotes. Nessa zona era permitido o acostamento em ambas as divisas laterais, bem como edificar sobre o alinhamento fronteiriço do lote.

$\mathrm{Na} 1^{\mathrm{a}} \mathrm{ZR}$ era admitida a altura máxima de uma vez e meia a largura da via em que a construção estivesse localizada, exceto para os imóveis situados na av. Manoel da Nóbrega, na orla marítima, onde os edifícios poderiam atingir quinze pavimentos, ou $50 \mathrm{~m}$ de altura. $\mathrm{Na}$ orla e na av. Presidente Wilson, principal via de ligação entre a praia de Itararé e o Centro, o recuo frontal mínimo era de $7 \mathrm{~m}$. A taxa de ocupação máxima nessa zona era de $65 \%$ da área do lote; e os recuos mínimos admitidos eram de $5 \mathrm{~m}$, à frente, de $1,5 \mathrm{~m}$ nas laterais e de $3 \mathrm{~m}$ ao fundo.

$\mathrm{Na} 2^{\text {a }}$ ZR e $3^{\text {a }}$ ZR a altura máxima admitida para as edificações era de três pavimentos. N $3^{\text {a }}$ ZR poderiam ser construídos "prédios para estabelecimentos comerciais, indústrias, armazéns, depósitos e estábulos". Nessa mesma zona admitia-se, ainda, a construção de moradias do "tipo econômico", com critérios a serem "futuramente estabelecidos". Tal dispositivo denotava não haver urgência no disciplinamento das construções para a população de baixa renda. 
Em qualquer das zonas residenciais era tolerada a construção de prédios conjugados, limitados a dois, sendo que na $2^{\mathrm{a}} Z R$ e $3^{\mathrm{a}} \mathrm{ZR}$ esse número poderia chegar a seis unidades. Em loteamentos na $3^{\underline{a}}$ ZR era admitido 0 acostamento em uma das divisas laterais, desde que 0 proprietário limítrofe o consentisse.

Para a Ilha Porchat, no extremo sul da Praia de Itararé ${ }^{96}$, era preconizada a implantação de um loteamento nos moldes das "cidades-jardim". Nesta ilha seria permitida a edificação de casas e prédios para fins residenciais, sendo que, o estabelecimento de hotéis e centros comerciais eram admitidos em áreas especialmente designadas para esse fim.

Posteriormente, a Lei $n^{\circ} 867$, de 1962 , vedava a construção de edifícios de apartamento, mas a Ilha Porchat, localizada em sítio extremamente privilegiado do ponto de vista paisagístico, acabou por ser ocupada por vários edifícios com mais de dez pavimentos, no mesmo padrão de urbanização da Praia de Itararé, terminando por desfigurar, por completo, seu sítio natural.

Portanto, do ponto de vista da segregação espacial, o Código de Obras de 1956 surgia para garantir a apropriação da orla marítima ao chamado turismo de segunda residência, ou turismo balneário, tal como ocorreu com Santos em igual período. Não se procurou incentivar o estabelecimento de uma rede hoteleira na cidade. O grande filão passava a ser a exploração imobiliária máxima possível dos terrenos junto ao mar.

$96 \mathrm{Na}$ verdade, a ilha transformou-se em uma península, pois seu acesso rodoviário foi construído por meio de um aterro.
Para tal fim, era fundamental afastar as construções modestas para as áreas mais distantes da orla, no que certamente a lei obteve inteiro sucesso, pois o padrão de urbanização em São Vicente passou a apresentar um imenso contraste, desde então. Ao longo das praias de Itararé e Gonzaguinha, de paisagem belíssima, edificou-se a mesma "muralha que cerca o mar", que surgiu junto à orla de Santos, tomando-se emprestada a expressão cunhada por SEABRA (1979) - ver Figura 35.

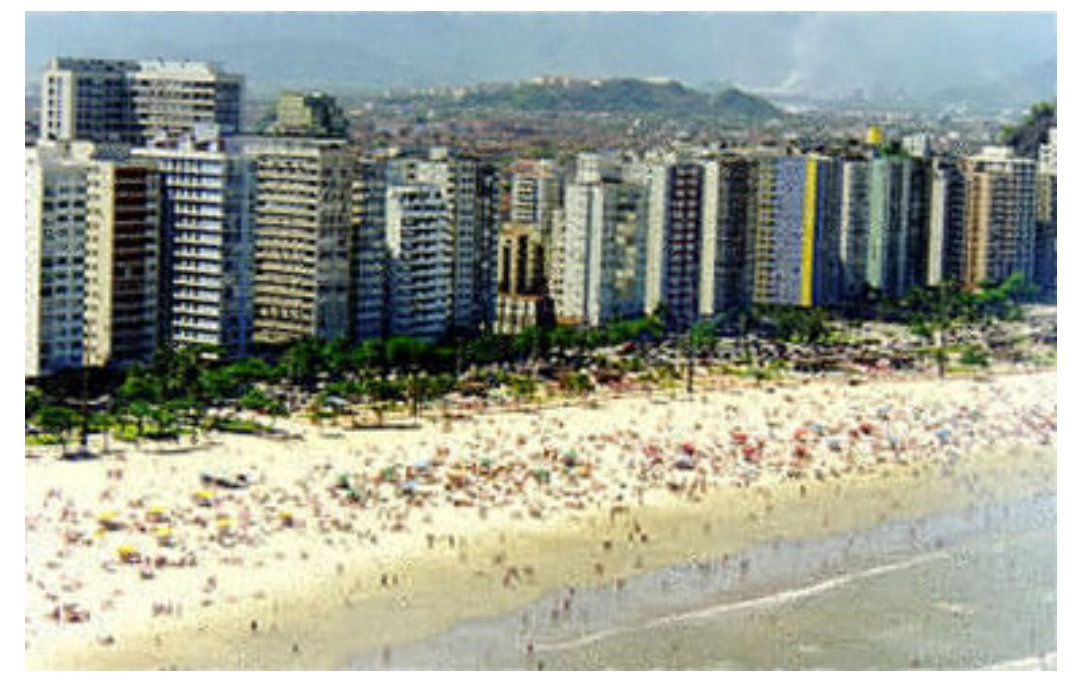

Figura 36 - Muralha de edifícios na Praia do Itararé, São Vicente. Fonte: sítio da Prefeitura Municipal de São Vicente na rede mundial de computadores - www.saovicente.sp.gov.br. Foto: Emílio Mansur.

$\mathrm{Na}$ orla vicentina, o padrão de parcelamento do solo era o de lotes de maior dimensão, possibilitando maior verticalização. Ao passo que no restante da cidade, com 
algumas exceções, a tônica era o pequeno lote e edificações que raramente ultrapassavam 0 segundo pavimento.

A vila, o conjunto de casas geminadas e, em menor número, o "chalé" de madeira, foram circunscritos às áreas mais distantes da orla e do centro, sobretudo à área ao norte da linha férrea que, tal como ocorreu em Santos, passou a constituir-se em limite real entre áreas mais e menos valorizadas.

A Lei № 2.025, de 9 de julho de 1985, que estabelecia normas de ordenamento e disciplina da ocupação do território do Município de São Vicente e uso do solo da área insular, na verdade abrangia as demais áreas do município localizadas no continente, até que no mesmo ano foi aprovada e sancionada a Lei № 2.061, que dispunha sobre o uso do solo da área rural de Samaritá.

A Lei № 2.025 era uma lei enxuta, com apenas 41 artigos, que dispunha sobre critérios para uso, ocupação e parcelamento do solo. Esta lei criava uma nova divisão em zonas, que abrangia todo o município. O Capítulo I, com três artigos, era apenas introdutório.

O Capítulo II tratava do zoneamento de uso e ocupação em si. Em seu artigo 4ำ eram assim descritas as zonas: Zona 1 - Z1, circunscrita ao centro entre a rua Padre Anchieta e av. Capitão Mor Aguiar - direção leste-oeste - e entre a linha férrea e a orla marítima - direção norte-sul; Zona 2 - Z2, área de maior valor imobiliário da cidade, entre o centro e a orla marítima; Zona $3-Z 3$, restante da parte plana da área insular do município, onde já havia se estabelecido a maior parte da população de média e baixa renda; Zona 4 - Z4,
Ilha Porchat; Zona 5 - Z5, morros do Voturuá e Itararé que separavam a Z2 da Z3; Zona 6 - Z6, Morro do Barbosa, no final da Praia do Gonzaguinha, ao norte da Ponte Pênsil; Zona 7 - Z7, morros Prainha e Japuí, assim como a Praia de Paranapuã, áreas de preservação no litoral da área continental; Zona 8 - Z8, área plana do bairro do Japuí, ao sul Ponte Pênsil, área onde se localizavam clubes náuticos e loteamentos de baixa renda; Zona 9 - Z9, Planície de Samaritá, entre as divisas com Praia Grande e a rodovia Cubatão-Pedro Taques, incluindo-se a parte norte do loteamento Parque das Bandeiras, do outro lado daquela rodovia; Zona 10 - Z10, planície entre o Rio Branco e a rodovia Cubatão-Pedro Taques; e Zona Rural, área entre o Rio Branco e a vertente atlântica da Serra do Mar.

No mesmo artigo foram também definidos corredores - tipo 1, tipo 2, tipo 3, especiais e turísticos - que eram os principais eixos viários, os quais poderiam admitir maior concentração de atividades econômicas conforme a área da cidade.

Quanto aos usos, na Z2 seriam vedadas garagens de ônibus, transportadoras, indústrias extrativas e pesadas, auditórios, discotecas, clubes noturnos, motéis e pensões. $\mathrm{Na} Z 3$ seriam vedadas as mesmas atividades à exceção de auditórios. $\mathrm{Na} Z \mathrm{Z4}$, a llha Porchat, seriam proibidos comércio, indústrias, motéis, atividades financeiras e pensões.

Surpreendentemente, na Z5, que compreendia os morros junto à orla marítima do Itararé, seriam admitidas residências, embora fosse área de difícil aproveitamento, pois na maior parte a declividade ultrapassa $30 \%$, o que 
impedia a aprovação de qualquer parcelamento, conforme dispunha o artigo 13.

Na Z9, maior parte da Planície de Samaritá, onde já estavam consolidados alguns loteamentos típicos de periferia - com baixo nível de oferta de equipamentos, infraestrutura e serviços - seria permitido parcelar, implantando lotes com área mínima de $125 \mathrm{~m}^{2}$ e frente mínima de $5 \mathrm{~m}$, sendo que, no geral a lei permitia parcelamentos com lotes de área mínima de $250 \mathrm{~m}^{2}$ e frente mínima de $10 \mathrm{~m}$. Nesta zona era vedado o estabelecimento de indústrias pesadas.

O parágrafo $3^{\circ}$, do artigo $6^{\circ}$, estabelecia a proibição da construção de edifícios conjugados, nas zonas 1, 2 e 4. Nas demais zonas era admitida a construção de renques de até cinco unidades. O parágrafo $8^{\circ}$, do mesmo artigo estabelecia a possibilidade de desmembramento de lotes, com área mínima de $125 \mathrm{~m}^{2}$ e frente mínima de $5 \mathrm{~m}$, admitindo-se o acostamento nas divisas laterais.

O parágrafo 15 , do artigo $6^{\circ}$, estabelecia a possibilidade de edificar até a altura de $35 \mathrm{~m}$ na Z2, o que era uma redução do limite admissível para a avenida da orla da Praia do Itararé e da av. Presidente Wilson, em relação ao Código de Obras de 1956.

Os capítulos II e IV tratavam de critérios e normas de parcelamento do solo, penalidades e disposições gerais. Cabe ressaltar que em relação aos recuos foram mantidos, praticamente, os mesmos critérios do Código de 1956.

Esta lei não faz qualquer menção a moradias econômicas ou edificações de madeira. Na verdade, o que mais se aproxima de uma moradia tipicamente popular, são as construções conjugadas, popularmente conhecidas como geminadas, que não eram admitidas na orla marítima, centro e Ilha Porchat. Mesmo assim, a área mínima admitida para um lote era $125 \mathrm{~m}^{2}$, conforme previsto no inciso II, do artigo 4ํㅡㄹ da Lei Federal de Parcelamento do Solo, № 6.766 .

Na mesma data em que a Lei № 2.025 foi sancionada, foi à sanção o novo Código de Obras do Município de São Vicente, Lei № 2.026, de 1985, que passava a regular apenas os aspectos técnicos e processuais das construções.

Nesta lei vale destacar apenas seu artigo 22, que estabelecia as dimensões mínimas de cômodos em construções residenciais, as quais passaram a ser $8 \mathrm{~m}^{2}$ para sala em unidades de um dormitório, $10 \mathrm{~m}^{2}$ para sala em unidades de dois dormitórios, $12 \mathrm{~m}^{2}$ para sala em unidades com mais de dois dormitórios, $12 \mathrm{~m}^{2}$ para dormitório em unidades de apenas um dormitório, $10 \mathrm{~m}^{2}$ para dormitórios em unidades de dois dormitórios, $8 \mathrm{~m}^{2}$ para dormitórios em unidades com mais de três dormitórios.

Neste aspecto, podemos ressaltar que mesmo para as unidades conjugadas as dimensões mínimas dos compartimentos eram superiores às dimensões adotadas no grande número das moradias populares na Z3 e na Planície de Samaritá.

A Lei № 2.061, de 26 de dezembro de 1985, alterava dispositivos da Lei № 2.025, do mesmo ano, definia e delimitava as Zonas Urbanas, Especiais, de Preservação Ambiental e Rural da área de Samaritá. Esta lei atendia provavelmente à pressão dos empresários da área de promoção imobiliária que intensificavam seus investimentos 
na área continental de São Vicente, sobretudo na Planície de Samaritá. São dessa época grandes loteamentos como o Conjunto Residencial Humaitá e o Jardim Rio Branco.

É importante observar que a ocupação da área continental de São Vicente e das áreas ambientalmente frágeis da sua área insular foi fundamental como forma de aliviar a pressão da população de baixa renda, com vínculos de trabalho na construção civil dos condomínios da orla marítima, na cidade de Santos e Pólo Industrial de Cubatão, pela busca por moradia. Assim, na ausência de uma política habitacional que propiciasse financiamento acessível, a oferta de terra barata em loteamentos desprovidos de quase toda a infra-estrutura, era a alternativa habitacional por excelência para grande parcela da população da Baixada Santista.

Até hoje, a Planície de Samaritá, e em menor grau os manguezais da área insular do Município (ver Mapa 2 e Figura 36), prosseguem sendo essa alternativa possível de possuir o próprio chão. No entanto, a questão do transporte dos moradores dessa região, pela distância enorme entre residência e trabalho, tornou-se crucial e um problema político de grandes dimensões para São Vicente e Santos.

A Prefeitura de São Vicente vem sendo obrigada, desde o princípio da ocupação de Samaritá, a prover a área continental de infra-estrutura e serviços que os empreendedores imobiliários não implantaram naquela região. Assim, o custo dessa opção pela ocupação da área continental acaba por ser debitado na conta de todos os munícipes, enquanto que o lucro permaneceu concentrado na mão do setor da promoção imobiliária.

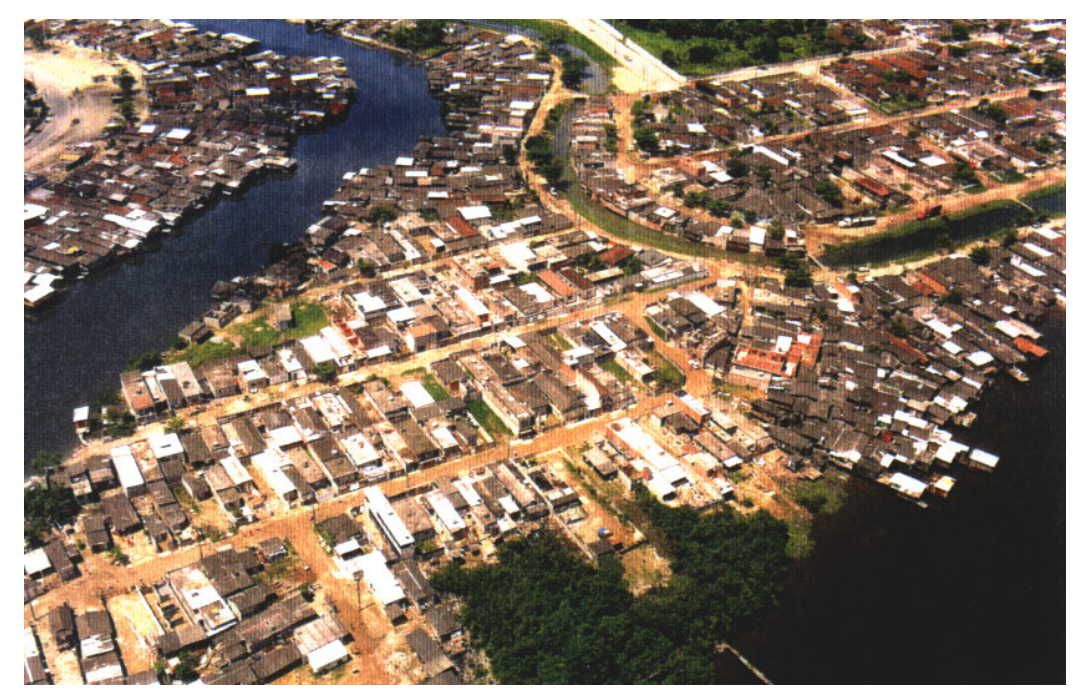

Figura 37 - Ocupações irregulares no Dique do Sambaiatuba em São Vicente, junto à Zona Noroeste de Santos. Foto: Prefeitura Municipal de São Vicente, 2000.

A Lei № 2.061, de 1985, no artigo 6o, da Seção I, do Capítulo III, estabelecia seis tipos de zonas na área continental: Zona Central - ZCE, Zona Residencial - ZR, Zona Comercial - ZC, Zona Industrial - ZI, Zona de Uso Especial 1 - ZUE 1, Zona de Uso Especial 2 - ZUE 2. Foram criados, ainda Corredores Comerciais - CC.

As ZCE seriam áreas de uso misto; as ZC seriam áreas de comércio varejista, atacadista e prestação de serviços; e as ZR, áreas predominantemente residenciais, nos loteamentos da área continental. As ZUE não poderiam ter mais do que $80 \%$ de sua cobertura vegetal suprimida, sendo que as ZUE 1 seriam destinadas a cultura, lazer e recreação, e as ZUE 2 reservadas para Parques Públicos. 
Os Corredores Comerciais seriam as principais artérias viárias dos loteamentos, onde poderiam concentrar-se comércio e prestação de serviço.

Essa lei definiu, ainda, em seu artigo 10, da Seção II, que tratava do uso e ocupação do solo, as categorias de uso. Eram elas: Residencial Unifamiliar - R1; Residencial Multifamiliar - R2, dividido em R2 01 - moradias horizontais, e R2 02 - moradias com até três pavimentos; e Residencial para conjuntos habitacionais - R3.

As dimensões mínimas para lotes do tipo $\mathrm{R} 1$ foram fixadas em $250 \mathrm{~m}^{2}$, com $10 \mathrm{~m}$ de frente. Para os do tipo R2 01, de $125 \mathrm{~m}^{2}$, com $5 \mathrm{~m}$ de frente, sendo que seriam admitidos grupos de até 16 moradias conjugadas - as vilas. Para os lotes do tipo R2 02 seriam admitidos edifícios com até três pavimentos. Já nos conjuntos habitacionais - categoria tipo R3, predominante na área continental de São Vicente - a área mínima para loteamentos era de $20.000 \mathrm{~m}^{2}$, ou 200 unidades. As categorias R1 e R2 seriam permitidas nas ZC, ZCE, ZC e nos CC. As do tipo R3, seriam admitidas apenas nas ZR.

A construção de habitações de interesse social seriam previstas no parágrafo único, do artigo 24 , com lotes mínimos de $125 \mathrm{~m}^{2}$ e frente mínima de $5 \mathrm{~m}$. No entanto, as áreas mínimas dos compartimentos seriam as definidas pela Lei № 2.026, de 9 de julho de 1985, o Código de Edificações. 


\subsubsection{A regulação urbanística em Cubatão}

No sopé da Serra do Mar, passagem natural entre Santos e o planalto, no início da colonização da região, Cubatão foi ponto de parada das tropas que iam e vinham do interior de São Paulo. Várias trilhas e caminhos, partindo de Cubatão, serviram de ligação com o planalto. No entanto, foi apenas em 1792, com a construção da Calçada de Lorena $^{97}$, que as dificuldades na subida da serra foram amenizadas. No segundo Império foi construída a Estrada da Maioridade, em homenagem a D. Pedro II, que veio a melhorar as condições de transposição do maciço da serra.

Já no século XIX a localidade era conhecida como Porto Geral de Cubatão, constituindo-se num minúsculo povoado. Em 1833, a Lei Imperial $\mathrm{N}^{\circ} 24$ oficializou o povoado. No entanto, esta lei não foi efetivada e a localidade foi incorporada ao Município de Santos, em 1841. A este Cubatão pertenceu até 1949, quando então conquistou sua autonomia, tendo seu primeiro prefeito tomado posse em 9 de abril daquele ano.

Em 1867, com a inauguração da Estrada de Ferro São Paulo Railway Company, ligando o Porto de Santos ao interior da província, Cubatão passou a enfrentar um grande período de declínio, pois perdeu seu papel de ponto de passagem estratégico para os que subiam a serra.

Até 1940 a economia da cidade baseava-se, preponderantemente, na bananicultura e os bananais dominavam a maior parte da planície de Cubatão. No

\footnotetext{
97 O caminho recebeu esta denominação em homenagem a Bernardo José de Lorena, governador da Província de São Paulo entre 1788 e 1798.
}

entanto, na passagem do século XIX para o XX Cubatão começava, lentamente, a mudar. Em 1895 surgiu a primeira indústria, a Companhia Curtidora Mex, depois Costa Muniz Ind. Em 1916 foi a vez da Companhia Anilinas e produtos Químicos do Brasil instalar-se em Cubatão. Em 1918, instalou-se a Companhia Santista de Papel e, a partir de 1925, foi implantada a Usina Hidroelétrica Henry Borden ${ }^{98}$, da Light (ELETROPAULO, 1994).

Após a construção da Via Anchieta, sobretudo entre os anos de 1955 e 1975 a cidade consolidou seu papel de Pólo Industrial da Baixada Santista, com a inauguração da Refinaria Presidente Bernardes, da Petrobrás, em 1955 e da Companhia Siderúrgica Paulista - COSIPA, em 1959, entre outras indústrias do ramo petroquímico. No total, existem hoje 23 indústrias de grande porte operando no Município.

$\mathrm{Na}$ verdade, o fato de Cubatão ter-se constituído numa opção estratégica para os governos militares, sobretudo para implantação do pólo petroquímico, trouxe vantagens e desvantagens. Dentre as desvantagens, pela fragilidade do ecossistema estuarino e proximidade com a Serra do Mar, a súbita ocupação da planície cubatense trouxe fama mundial à cidade, como um dos locais mais poluídos do planeta.

Do ponto de vista da ocupação do território, é importante ressaltar a fragilidade das condições ambientais em Cubatão. Seu centro urbano de reduzidas dimensões, desenvolveu-se junto à curva do rio Cubatão que,

\footnotetext{
${ }^{98}$ A construção da Usina Henry Borden, idealizada pelo engenheiro Asa W. K. Billings iniciou-se em 1925, visando o suprimento de energia elétrica para o Estado de São Paulo.
} 
juntamente com o rio Mogi, deságua no estuário, formando um par de bacias, que recebem contribuição de diversos afluentes provenientes da Serra do Mar.

A localização das indústrias de maior porte, como a COSIPA, é justamente essa estreita faixa de terra entre os dois rios, muito próxima ao centro da cidade e bairros periféricos, fazendo com que a população residente sofra o impacto direto da poluição atmosférica e hídrica.

Os eixos viários estruturadores do Município são as rodovias Anchieta e Imigrantes, na direção norte-sul; e Cubatão-Pedro Taques ${ }^{99}$ e Dom Domenico Rangoni ${ }^{100}$, na direção leste-oeste (ver Figura 38). O primeiro é a ligação do Planalto com a Baixada, o segundo é a ligação litoral norte com o litoral sul do Estado. Ao longo destes eixos desenvolveu-se a ocupação urbana e industrial, de forma bastante fragmentada e dispersa.

No entanto, os impactos negativos ao ambiente natural da região não estão limitados, no caso de Cubatão, à implantação do pólo industrial petroquímico. Desde a construção da Via Anchieta, Cubatão tornou-se um município habitado, sobretudo por trabalhadores de baixa renda e qualificação, com vínculo de emprego e renda nas empreiteiras de construção civil e nas próprias indústrias locais.

\footnotetext{
99 Faz a ligação entre o Sistema Anchieta-Imigrantes com a Rodovia Padre Manuel da Nóbrega, que leva ao litoral sul e Vale do Ribeira.

100 Também conhecida como rodovia Piaçaguera-Guarujá, faz a ligação entre o Sistema Anchieta-Imigrantes e a Rodovia Rio-Santos.
}

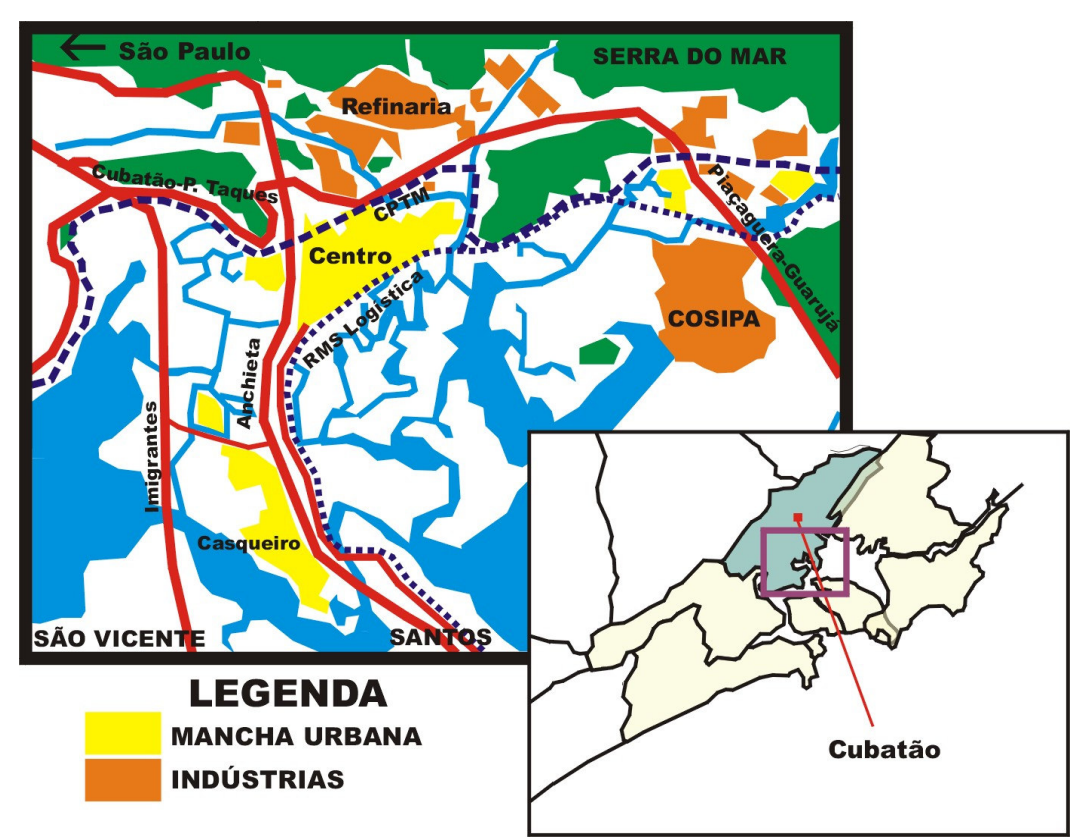

Figura 38 - Principais eixos estruturadores do Município de Cubatão.

Derrotados na luta por melhores localizações na Baixada Santista e buscando maior proximidade com os locais de trabalho, milhares de migrantes construíram suas moradias em assentamentos irregulares, em áreas ambientalmente frágeis, espalhadas por todo a área de planície cubatense e nas encostas da Serra do Mar. Acompanhando a ferrovia como a Vila Esperança - ou seguindo serra acima a Via Anchieta - como os cinco assentamentos denominados bairros Cota - a população de baixa renda formou uma teia de assentamentos com condições de habitabilidade extremamente precárias. 
É importante ressaltar, que a maior parte dos trabalhadores de Cubatão, sobretudo os mais qualificados, procurou outras cidades da região para morar, consolidando o perfil de população de baixa renda em um município rico, em função de sua base industrial ${ }^{101}$.

Outra questão relevante para o objetivo deste trabalho é o fato de que alguns assentamentos subnormais em Cubatão, sobretudo os localizados mais a sudeste, possuem vínculo maior com o processo de ocupação do município de Santos, como o caso da favela Vila dos Pescadores, junto ao canal do estuário, em área de domínio da Rede Ferroviária Federal, quando iniciou-se a ocupação e, atualmente da RMS Logística (ver Mapa 3 e Figura 39).

Acerca desta relação entre Santos e Cubatão, GOLDENSTEIN (1993: 28) observou:

"Uma parte significativa do pessoal fixo das indústrias não mora em Cubatão. Santos, São Vicente e Cubatão constituem uma conurbação na qual Santos é a cidade principal, que detém os equipamentos de serviços mais especializados e diversificados. Cubatão, centro recente e não planejado, é subequipado, o que acentua os fluxos diários de mão-deobra.

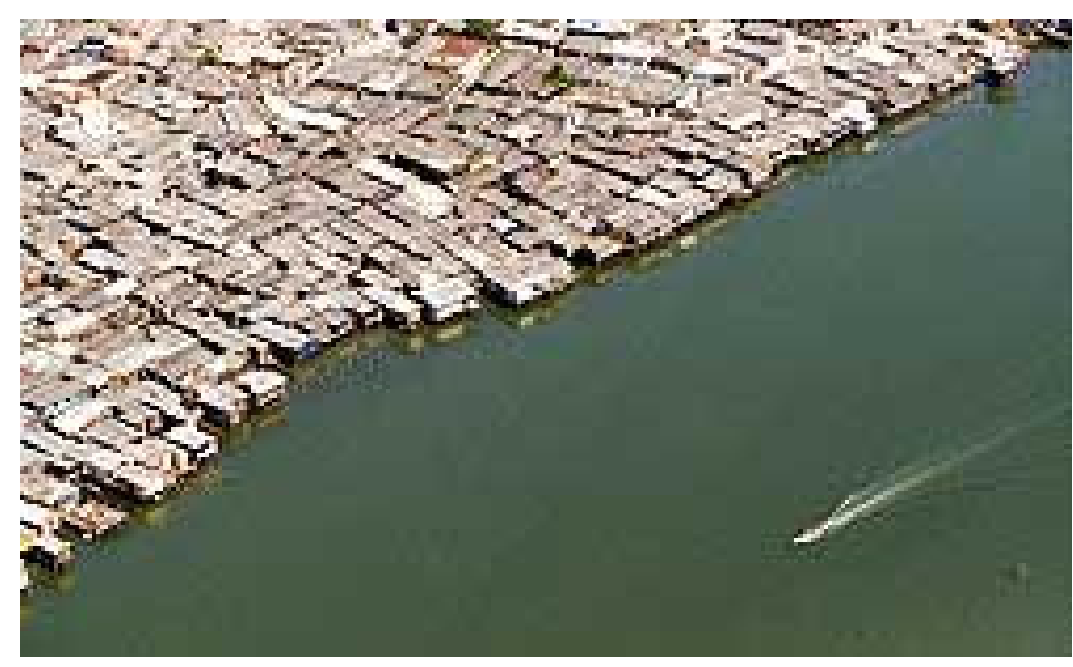

Figura 39 - Favela Vila dos Pescadores, Cubatão. Fonte: Jornal Folha de São Paulo, 2001.

Em 1968, em pesquisa que realizei, constatei que $70 \%$ da mão-de-obra moravam fora de Cubatão e, desses, $50 \%$ moravam em Santos. Dados atuais da prefeitura indicam que $56 \%$ dos trabalhadores moram em Santos. Não é, portanto, uma cidade integrada em si mesma. É um centro de indústrias grandes e dinâmicas, que vivenciaram um processo de integração horizontal e vertical".

Pode-se afirmar, ainda, que as iniciativas, por parte dos empresários do segmento industrial, no sentido de prover a mão-de-obra local com moradia foram insuficientes. Dentre estas poucas experiências de implantação de conjuntos habitacionais vinculados às indústrias de Cubatão, podemos citar a Vila Fabril, ou Cubatão de Cima, implantada como bairro operário da Companhia Santista de
101 Cubatão possui o maior valor adicionado da RMBS, (2,29 \% do total do Estado de São enquanto Santos tem, respectivamente, $R \$ 1.504 .394 .225,00$ e 0,63\%, segundo dados da Fundação SEADE, 2000. 
Papel. Em levantamento baseado em dados da FIBGE e GEGRAN, SERRANO (1991: 41) apontou, respectivamente, em 1980 e 1988, população de 15.038 e 29.719 habitantes em submoradias, no município de Cubatão.

$\mathrm{Na}$ verdade, tal como ocorreu nos demais municípios da região, a especulação imobiliária responsabilizou-se, em grande medida, pela ocupação desordenada no território do município. Em ELETROPAULOO (1994: 33-34) podemos ler:

"O processo industrial causou uma interferência sócio-econômica radical na composição da cidade. Rapidamente as terras tornaram-se alvo da especulação imobiliária e utilizadas para os vários loteamentos.

A população urbana subiu de 1.887, em 1940, para 18.885, em 1960, influenciando a saída de muitos dos antigos moradores, até enriquecidos com a venda de suas terras".

Acerca do processo de formação socioeconômica da população em Cubatão, pode-se ter em GOLDENSTEIN (1993: 28) outro excelente relato:

"O esquema de aproveitamento do pessoal foi sempre o mesmo: grande número de pessoas empregadas na fase de obras e um número reduzido permanecendo como mão-de-obra definitiva. Foi uma verdadeira escola de quadros intermediários, principalmente há 10 e 15 anos, quando a dificuldade em encontrar empregados qualificados era bem maior.

Continua o afluxo de trabalhadores à procura de obras de expansão, as quais requerem grande número de pessoas. Constituem a mão-de-obra flutuante que engrossa as favelas da região. Só moram na cidade, nas favelas, nos loteamentos não urbanizados e mesmo nos melhores, os trabalhadores de baixa renda. $O$ crescimento populacional se dá a uma taxa de $5 \%$ ao ano. De uma população de 75 mil habitantes, 25 mil são constituídos favelados".

Outra questão relevante é que as sedes de sindicatos e agremiações recreativas das indústrias estão localizadas, majoritariamente, em Santos. Pode-se explicar esse fenômeno pelo fato de que Santos oferece melhor infraestrutura, atraindo os empregados de maior renda.

A melhoria da acessibilidade foi outro fator decisivo para a escolha de cidades vizinhas, pelos operários, para moradia. Isto ocorreu, pois uma vez que o local de trabalho era acessível, igualmente para o morador de Santos, São Vicente ou Guarujá, estas localidades constituíram-se nas localizações preferenciais para a mão de obra mais qualificada de Cubatão.

Essa realidade é verificada ainda hoje, pois embora Cubatão seja, segundo dados da Prefeitura local, responsável por cerca de $21 \%$ dos empregos da Baixada Santista, aproximadamente $80 \%$ desses empregos não pertencem a seus moradores.

GOLDENSTEIN (1993: 28) traçou um painel alarmante da qualidade de vida em Cubatão no início da década de 90 , quadro este que certamente tornou-se mais precário ao longo da década, em função do processo de privatização de empresas estratégicas como a COSIPA, que resultou em grande redução do número de empregos formais: 
"A falta de planejamento do ponto de vista econômico, como do ponto de vista espacial e social, levou a problemas graves. A simples enumeração de alguns o comprova:

- Grande desperdício de investimentos que repercute na capacidade de competição;

- concessão de privilégios que nem sempre levam em conta o custo social dos empreendimentos;

- falta de entrosamento entre os planejamentos dos municípios da Baixada, como no caso da criação de distritos industriais;

- sistema viário caótico e insuficiente;

- comunicações precárias;

- desequilíbrio ecológico".

Mas em que medida a legislação urbanística contribuiu para reforçar ou induzir este quadro de precariedade e exclusão social? Para responder esta pergunta analisou-se a legislação urbanística principal de Cubatão. No entanto, é importante esclarecer que, como bairro de Santos, antes de sua autonomia em 1959, Cubatão estava submetida à legislação deste município. Foi apenas em 1969 que foi sancionada a Lei $\mathrm{N}^{\circ} 776$, de 12 de novembro, que dispunha do uso do solo do Município.

Essa lei vigorou até 28 de junho de 1996, quando foi sancionada a Lei $\mathrm{N}^{\circ} 2.365$, que estabelecia o novo Plano Diretor de Desenvolvimento do Município de Cubatão, elaborada pela FUPAM/FAU USP.

Este Plano foi rapidamente revogado, em função de questões políticas, as quais não serão aprofundadas, relacionadas às restrições para ocupação do território, sendo que, em 10 de setembro de 1998, foram sancionadas as leis $\mathrm{N}^{\circ} 2.512$, que instituiu o Plano Diretor de Desenvolvimento Integrado; $N^{\circ} 2.513$, que disciplinou 0 Parcelamento, Uso e Ocupação do Solo; e $N^{\circ} 2.514$, que instituiu o Código de Obras e Edificações.

Essas últimas três leis estão hoje em vigor, mas a exemplo do Plano de 1996, não serão objeto de análise no presente trabalho, em função de não pertencerem ao período definido para este estudo, que vai até princípio da década de 80 . Portanto, nossa análise restringir-se-á à Lei $\mathrm{N}^{\circ} 776$, de 1969.

\subsubsection{Análise da legislação urbanística de Cubatão}

A Lei $N^{\circ} 776$, de 12 de novembro de 1969, que dispunha do Uso do Solo do Município de Cubatão, sancionada pelo engenheiro Aurélio Araújo, Prefeito Municipal, sob a vigência do regime de exceção, era um código de 50 artigos, distribuídos em 11 capítulos. $\mathrm{O}$ artigo $2^{\circ}$ estabelecia a divisão do território municipal em quatro zonas: Zona Urbana Prioritária de Planejamento - ZUPP, Zona de Possível Urbanização - ZPU, Zona Industrial - ZI, e Zona Rural - ZR.

Para a delimitação da ZUPP adotou-se o critério do Código Tributário Nacional para definição de zona urbana, ou seja, a presença de um mínimo de dois, dentre cinco itens indicativos de disponibilidade de atendimento por equipamentos e infra-estrutura urbana. Esta área correspondia aproximadamente ao atual centro e bairros contíguos como Vila Nova, Vila Natal, e ainda, os mais próximos de Santos, como Casqueiro, Ilha Caraguatá, Nhapium e Saracura. 
A ZPU, dividida em duas áreas, correspondia, aproximadamente às áreas a oeste da Via Anchieta, entre a Serra do Mar e a Vila Natal; e também, a leste da mesma rodovia - entre a Vila Nova e o Rio Casqueiro - e entre a linha da Rede Ferroviária Federal, hoje operada pela RMS Logística, e aquela rodovia.

A ZI correspondia, aproximadamente, à faixa de terreno entre a cota $100 \mathrm{~m}$ da Serra do Mar e a margem esquerda do Rio Cubatão, ao longo dos eixos das rodovias Cubatão Pedro Taques e Piaçaguera - Guarujá.

A ZR era a área correspondente aos limites do Parque Estadual da Serra do Mar, dentro do Município, ou seja, acima da cota $100 \mathrm{~m}$.

Por sua vez, a ZUPP foi dividida em setores enumerados de 1 a 9 e, ainda, as áreas do Novo Centro Urbano, Setor de Recreação e Área Verde. Nesta zona foram também criadas duas subdivisões, denominadas Zona Comercial 1 - ZC1 - e Zona Comercial 2 - ZC2, correspondentes ao atual centro da cidade (ver Figura 40). Na ZPU foi delimitado um Setor da Indústria Leve - SIL.

O artigo 12 estabelecia que na $\mathrm{ZI}$, "todas as áreas atualmente habitadas localizadas dentro dos - seus limites são declaradas em extinção a longo prazo". Em seu parágrafo $1^{\circ}$, a Vila São José, também conhecida como Vila Socó, favela construída sobre um oleoduto da Petrobrás, paralelamente à Via Anchieta, figurava como sendo um desses núcleos fadados à extinção. Trágica e ironicamente, esta favela veio a ser destruída, em 25 de fevereiro de 1984, quando um grande incêndio no oleoduto ceifou a vida de mais de 99 moradores, atingindo 470 moradias, na maior tragédia do século $X X$, que envolveu um assentamento subnormal, na Baixada Santista. Os moradores que sobreviveram foram transferidos para uma área próxima, que foi urbanizada.

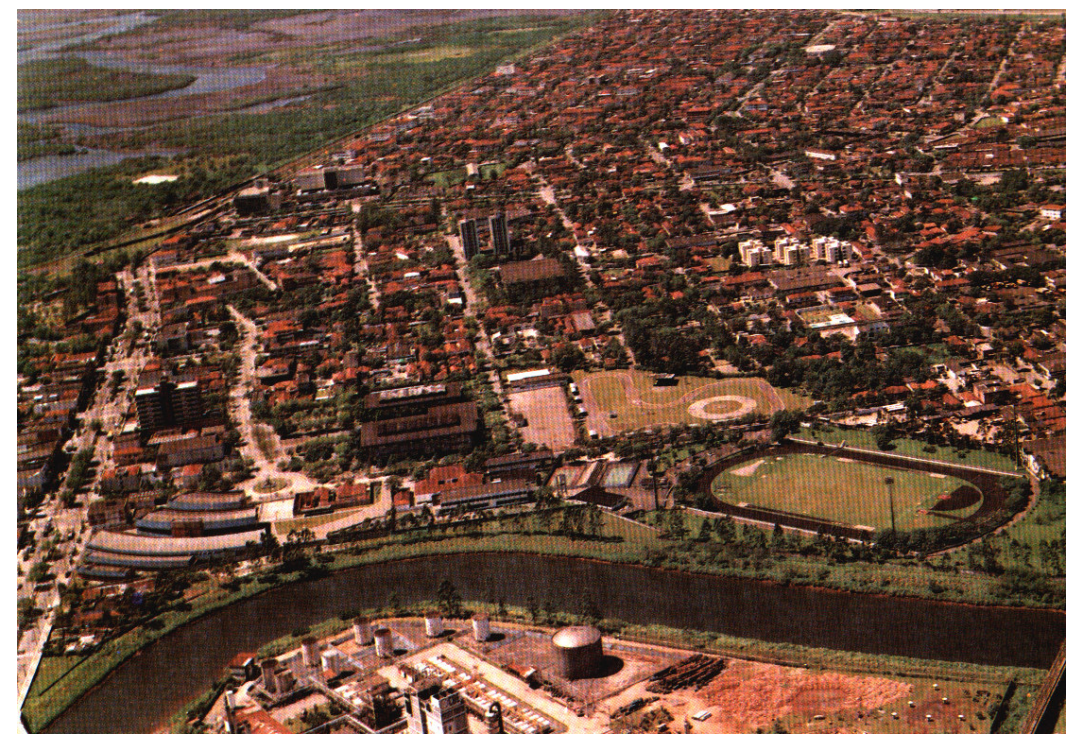

Figura 40 - Vista aérea da área central de Cubatão, com o rio de mesmo nome abaixo e, à esquerda, a avenida 9 de abril, principal eixo comercial da cidade. Fonte: Prefeitura Municipal de Cubatão.

Mais adiante, no parágrafo $2^{\circ}$ do mesmo artigo, excluía-se do rol dos assentamentos passíveis de extinção as vilas residenciais pertencentes às próprias indústrias, "desde que comprovadamente não existam no local condições nocivas à saúde".

O Capítulo VI - Do Uso das Zonas - estabelecia as classificações de atividades permitidas em cada zona. $\mathrm{Na}$ 
ZUPP eram admitidas residências e atividades de comércio e prestação de serviços, de baixo impacto. No entanto, nos setores 1, 4, 5, 6 e 7 seriam permitidas atividades comerciais apenas em lotes de esquina, o que revelava a intenção de constituir nessas áreas um território de maior exclusividade. Ao contrário de Santos, nas zonas comerciais não era vedada a construção de residências, apenas havia limitações ao aproveitamento do lote usado para tal fim.

$\mathrm{Na}$ ZPU, de forma bastante subjetiva, a lei remetia a edição de decreto para a futura regulamentação dos usos permitidos. $\mathrm{Na} \mathrm{ZI}$ eram admitidas indústrias pesadas, inclusive as "nocivas, incômodas e perigosas para a comunidade", bem como serviços complementares às atividades industriais. $\mathrm{Na}$ ZR seriam admitidas atividades agropecuárias.

Quanto à ocupação, definida no Capítulo VII, na ZUPP seria permitida ocupação de $66 \%$ da área total do lote, com recuos frontais de $4 \mathrm{~m}$. Nos lotes de esquina, onde 0 comércio era permitido, a taxa de ocupação poderia ser excedida em $10 \%$. A altura dos edifícios foi limitada em três pavimentos, admitindo-se um quarto, quando o térreo fosse destinado exclusivamente como garagem. Nas zonas comerciais a altura foi limitada em $37 \mathrm{~m}$.

No artigo 43, nas Disposições Gerais, a Prefeitura ficava "desobrigada de estender os serviços públicos e também de conservar os loteamentos para fins residenciais e de construções de qualquer natureza". Tal dispositivo demonstrava a clara disposição do poder público de ignorar suas responsabilidades sobre o já então grave problema do crescimento de assentamentos subnormais.
Observamos que esta lei não estabelecia dimensões de lotes, nem critérios para parcelamento do solo, questão que foi regulamentada posteriormente. Assim, podemos afirmar que se comparada a legislação urbanística em vigor, à existente na mesma época nos demais municípios centrais da RMBS - inclusive Guarujá, como será visto à seguir - a Lei $\mathrm{N}^{\circ} 776$ era extremamente simples e muito menos detalhada, demonstrando não haver naquele município uma preocupação tão marcante em criar territórios de exclusividade, quanto houve nas cidades litorâneas.

Isto se deve, possivelmente, ao fato de Cubatão não possuir uma classe média tão expressiva, quanto os demais municípios centrais da RMBS.

No entanto, da mesma forma que nestes municípios, mas em maior grau, ignorava-se a questão da habitação para as classes populares, problema de extrema gravidade na Cubatão da década de 70 , em que diversos núcleos já haviam se consolidado e estavam em franca expansão, como a Vila Parisi, próxima à COSIPA; os bairros Cota, na Serra do Mar; e a Vila dos Pescadores, entre a linha da Rede Ferroviária Federal e o estuário.

Portanto, pode-se concluir que ao se atribuir o papel de controlar a ocupação apenas na área onde atuava o mercado formal da cidade, declarando os assentamentos criados fora desses limites, como passíveis de extinção "a longo prazo", a Prefeitura empurrava para um futuro incerto o enfrentamento das péssimas condições habitacionais da população de baixa renda, que era a maioria no Município. Ou seja, a legislação urbanística de Cubatão, na década de 60 , fora concebida para a minoria de seus habitantes. 


\subsubsection{A regulação urbanística em Guarujá}

O Município de Guarujá ocupa inteira e exclusivamente a Ilha de Santo Amaro, uma das maiores do litoral paulista. A ilha, localizada entre a área continental de Santos, a llha de São Vicente e o oceano, é cortada na direção sudoestenordeste, por uma cadeia de morros conhecidos como Serra de Santo Amaro. Esta serra divide a sede do Município - que é a região da orla marítima - do distrito de Vicente de Carvalho - junto ao estuário de Santos (ver Figura 41).

O território de Guarujá foi utilizado nos três primeiros séculos da colonização portuguesa apenas para atividades agrícolas, sobretudo vinculadas à exploração da cana-deaçúcar. Em 1540, foi fundado o primeiro povoado da llha de Santo Amaro, por Estevam da Costa e Jorge Ferreira. Em 1545, houve a instalação do primeiro engenho de cana-deaçúcar; e a construção das capelas de Nossa Senhora da Apresentação e de Santo Amaro, esta última erguida por José Adorno, que deu nome definitivo a llha.

A denominação anterior da Ilha, de origem Tupi, era Guaibê ou Guaru-ya. Guaibê significa Lugar de Caranguejo; Guaruya significa Passagem Estreita, ou Viveiro de Sapos. Os primeiros colonizadores portugueses ao chegarem à região trouxeram outra pronúncia ao nome Guaru-ya, que passou a ser Guarujá. Ao se construir a capela em homenagem a Santo Amaro, deu-se o nome definitivo à llha que abrigava Guarujá.

A respeito desses primeiros séculos pode-se ler em ANDRADE (1989: 19) que, "As tentativas de colonização de Santo Amaro foram fracassadas e a ilha só tinha importância devido aos fortes que protegiam os canais - o de Santos e o da Bertioga -, e, a partir do século XVIII devido às armações da pesca de baleia. Foi, pois, na Ilha de S. Vicente que as coisas aconteceram".

Em 1670, teve início a construção da Fortaleza do Itapema, atual distrito de Vicente de Carvalho, para defesa do canal do estuário de Santos contra as incursões de piratas. Pouco depois, em 1699, foi fundada a primeira indústria daquela ilha, a Armação das Baleias, que funcionou entre 1699 e 1830, no Canal de Bertioga.

Mas foi efetivamente no final do século XIX, com a fundação da Vila Balneária - conjunto de chalés no local da atual Praia de Pitangueiras - que se iniciou a ocupação de Santo Amaro. Segundo SILVA SOBRINHO (1953:134), os chalés surgiram em 1898 no Guarujá, "cuja povoação consta de sessenta chalés de lindo gosto americano, na maior parte de madeira, no meio de bonitos jardins e iluminados à luz elétrica..." apud ANDRADE (1989: 220).

A Vila Balneária era uma estância destinada à aristocracia cafeeira paulista. Os chalés, sendo 46 em madeira importada dos Estados Unidos, faziam parte de um conjunto com hotel, igreja e cassino. Esta vila tinha acesso por ferrovia até o atual distrito de Vicente de Carvalho, onde as famílias tomavam barcas para chegar na estação ferroviária da São Paulo Railway Company, no bairro santista do Valongo, por onde seguiam até a Estação da Luz, na Capital.

Foi na virada do século XIX para o XX que o turismo balneário começava, lentamente, a florescer na Baixada e, sem nenhuma dúvida, Guarujá, de todos os municípios 
centrais era o que dispunha do mais belo litoral, delineado por morros, costões rochosos e praias de areia branca e grossa, daí a preferência da alta sociedade pelo local.

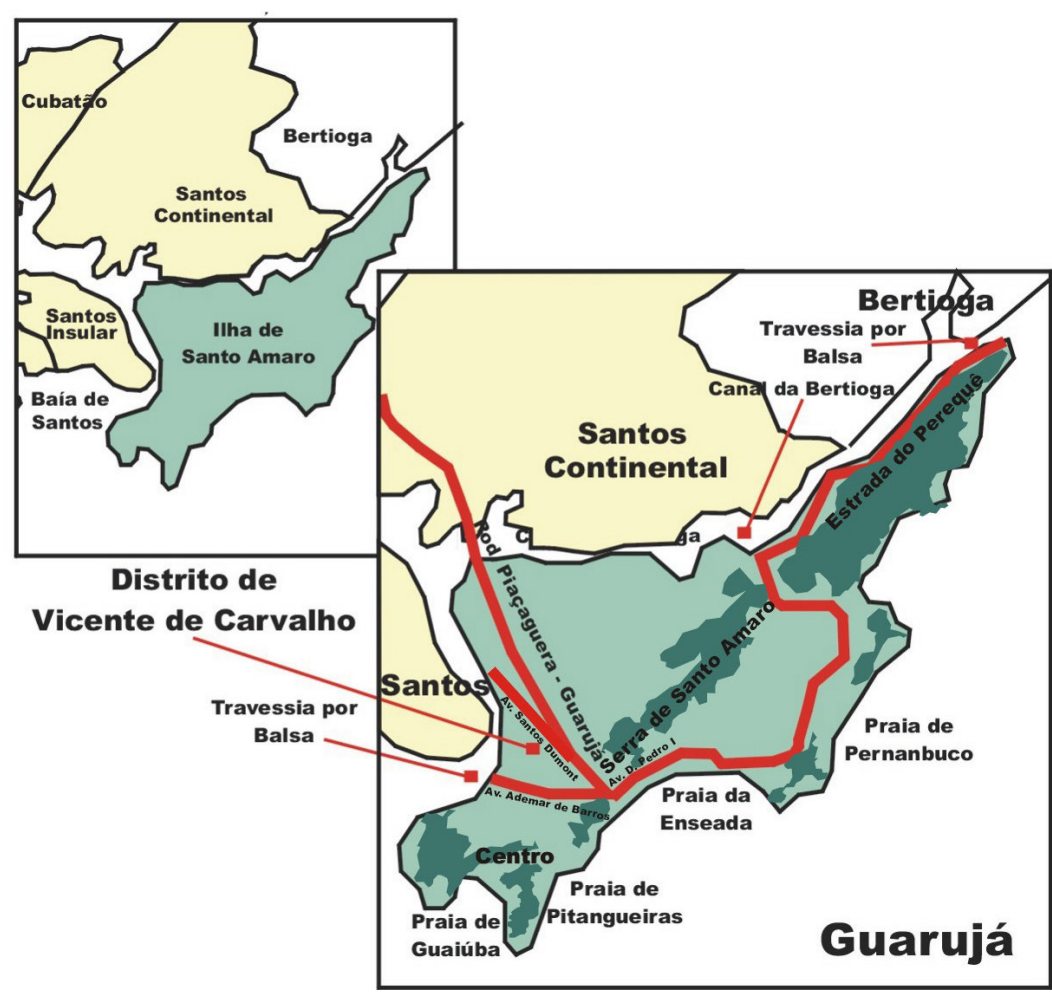

Figura 41 - Município de Guarujá, localização e principais eixos viários.

No início do século, a área do atual distrito de Vicente de Carvalho, então conhecida como Itapema, era dominada por plantações de bananas, as maiores riquezas agrícolas da ilha. Após a década de 1920, Guarujá viveu a fase áurea do jogo e do turismo.

Em 1923, foi criado o Distrito de Paz de Guarujá, e em 1931 Guarujá foi integrado ao Município de Santos, situação que perdurou até 1934. Pelo Decreto $N^{\circ} 1.525$, de 30 de junho de 1.934, o Governador Armando Salles de Oliveira criou a Estância Balneária de Guarujá, concedendo à cidade sua emancipação administrativa e nomeando o Dr. Cyro de Mello Pupo, seu prefeito. Em 1949, foi instalada a primeira Câmara Municipal de Guarujá e logo em seguida, em 1953, foi criado o Distrito de Vicente de Carvalho.

Até a inauguração da Via Anchieta, que possibilitou o incremento do turismo balneário, sobretudo pela classe média, a população de Guarujá mal ultrapassava os 13.000 habitantes. Na secada de 60 ela ultrapassou os 40.000 habitantes e, ao final da década de 70 , eram registrados cerca de 94.000 moradores. No entanto, a explosão da ocupação do território do Guarujá deu-se nas décadas de 70 e 80 , quando a população atingiu a marca de 151.000 habitantes.

Como apontou SERRANO (1991: 53): "As favelas em Guarujá surgiram após a segunda guerra mundial. Foram geradas, em primeiro momento, como um transbordamento da ocupação residencial de trabalhadores da Cidade de Santos, em decorrência do crescimento das atividades portuárias. Posteriormente, uma dinâmica econômica própria do município de Guarujá, principalmente ligada à construção civil, passou a alimentar o surgimento e crescimento dos novos agrupamentos". 


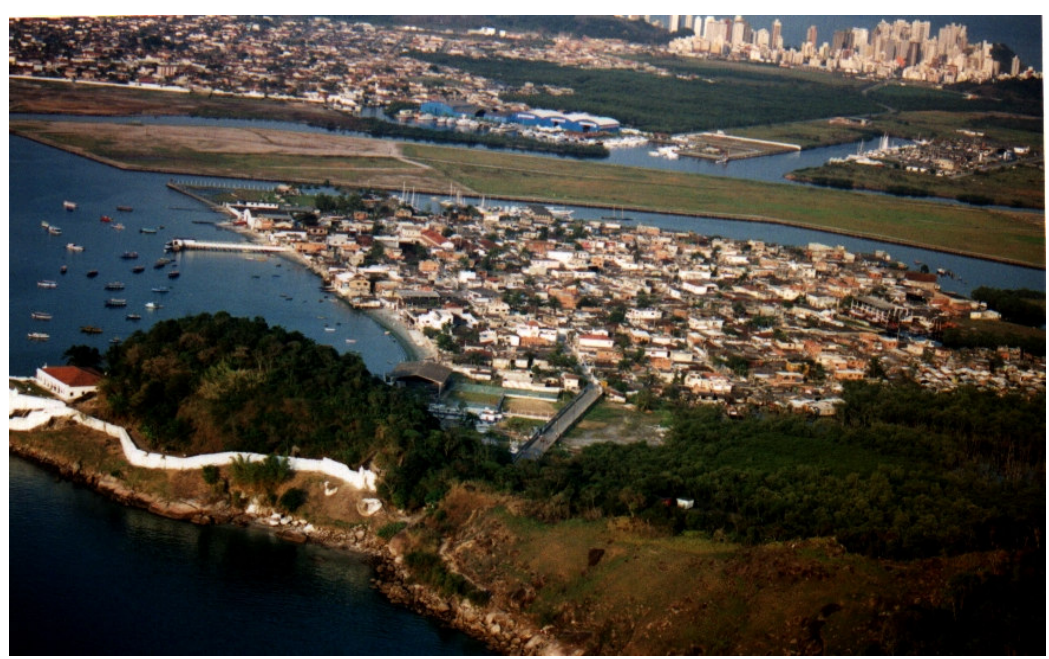

Figura 42 - Em primeiro plano a Praia de Santa Cruz dos Navegantes, já quase que inteiramente urbanizada, que foi uma das primeiras favelas de Guarujá, na entrada do canal do estuário. Ao fundo vê-se o paredão de edifícios da Praia de Pitangueiras. Foto do autor, 2000.

Em seu Plano Regional, o urbanista Prestes Maia propunha, em 1950, a implantação de uma Nova Santos na margem esquerda do estuário, em Vicente de Carvalho. Com terrenos já escassos na llha de São Vicente, a vasta planície a noroeste da Ilha de Santo Amaro afigurava-se como área ideal para a implantação de uma cidade "comercial e portuária", que seria ligada à margem direita por uma ponte elevadiça, na direção do cais dos Outeirinhos, em Santos. No entanto, para que a proposta fosse efetivada, seria necessária a implantação de infraestrutura urbana de porte, tarefa que não interessou nem ao poder público, nem a iniciativa privada que, àquela altura, já tinha seu foco voltado para a orla marítima.
Durante a década de 70 iniciou-se a implantação da margem esquerda do Porto de Santos, com a inauguração do ramal de Conceiçãozinha, da antiga Rede Ferroviária Federal. Implantaram-se, então, vários terminais portuários e retroportuários especializados, ao longo do canal, no Distrito de Vicente de Carvalho. Este fato foi decisivo para a forte pressão por moradia para a classe operária ligada ao setor portuário. Na verdade, como escreveu NUNES (2001: 147), a expansão do porto na margem esquerda era idéia antiga, pois desde 1925 já era tema de debates.

Foi entre as décadas de 60 e 80 que se definiu, claramente, o padrão da segregação social entre a orla marítima e Vicente de Carvalho. $\mathrm{O}$ alto valor dos terrenos junto à praia, visados pelo setor da promoção imobiliária para produção de unidades de veraneio, virtualmente delimitou o território ocupado pela alta renda, sobretudo composta por turistas originários da RMSP e interior do Estado.

A população de baixa renda ficou segregada, como apontou SERRANO (1991), às planícies de Vicente de Carvalho, às encostas interiores da Serra de Santo Amaro e, em menor proporção, em outras áreas onde a especulação imobiliária também não demonstrou interesse (ver Mapa 4).

Com vínculo trabalho na construção civil, nos serviços ligados ao turismo e à indústria naval, nas indústrias de Cubatão e no porto, a população de baixa renda acabou por ocupar preponderantemente a vasta planície ao norte da Serra de Santo Amaro, onde antes existiam os bananais. A própria Serra começou a ser ocupada por esta população, reproduzindo ali as terríveis situações de risco geológico já verificadas nos morros de Santos. 
Em 1982, a FIBGE já contabilizava 5.310 submoradias em Guarujá, num total de 20.451 nos municípios centrais da Baixada. Ainda, segundo SERRANO (1991: 35), entre 1980 e 1988, a população favelada dos municípios centrais dentre estes estando incluída a cidade de Praia Grande sofreu acréscimo de 200,6\%. O mesmo autor revela, adiante, que no início da década de 1990 a população residente em submoradias no Guarujá atingia $28 \%$ da população total, descontada a população dos núcleos Pae Cará ${ }^{102}$ e Vila Zilda, que haviam sido objeto de intervenções urbanísticas. Para uma avaliação mais aprofundada da segregação espacial no município de Guarujá, até a década de 80 , é essencial a leitura da obra de SERRANO.

A respeito da relação entre segregação e construção civil, pode-se ler em FARAH (1998: 36):

"Em muitas cidades litorâneas e serranas de pequeno e médio porte, associadas ao turismo, o quadro se repete. Nelas, a atividade da construção civil, apesar da crise, foi capaz de manter algum nível de emprego, ampliado pelo comércio e pela prestação de serviços aos turistas. Nestas cidades, a especulação imobiliária tende a esgotar as planícies rapidamente, destinando-as ao turismo, comprimindo a população de baixa renda em direção às encostas. Às belezas naturais (e construídas?), por exemplo, em Ubatuba, Guaruiá e Campos do Jordão no Estado de São Paulo, e em tantas outras localidades turísticas, Brasil afora, contrapõem-se favelas e loteamentos problemáticos em encostas, quase sempre longe das vistas dos turistas" (grifo do autor).

\footnotetext{
102 Também grafado Pae-Cará ou Pai-Cará.
}

Para que fosse possível avaliar a interface entre legislação urbanística e exclusão espacial, estudou-se o conjunto das leis urbanísticas do município de Guarujá, que tiveram maior relevância.

\subsubsection{Análise da legislação urbanística de Guarujá}

A principal fonte de pesquisa utilizada para a análise da legislação urbanística de Guarujá é a publicação elaborada pela Ricoy Torres e Colonelli, Consultoria e Projetos S/C Ltda., empresa contratada em 1986, pela Prefeitura local, com a finalidade de fazer a revisão das leis № 1.266, de 27 de novembro de 1975 - Plano Diretor - e № 1.421, de 20 de abril de 1979 - Zoneamento de Uso do Solo e Sistema Viário do Município do Guarujá.

Esta coletânea abrange e reproduz, integralmente, por ordem cronológica, toda a legislação urbanística do Guarujá, no período objeto da presente pesquisa, desde seu marco inicial, a Lei № 319, de 3 de dezembro de 1955, que instituiu o Código do Município do Guarujá e, também, reproduz toda a legislação estadual e federal pertinentes.

No total, a coletânea apresenta 47 leis e decretos, dentre os quais comentar-se-á apenas os principais códigos e planos aprovados, desprezando alterações pontuais, bem como a legislação estadual e federal, da mesma forma que procedemos com o estudo da legislação urbanística dos demais municípios centrais da RMBS.

Merece menção o fato de que dois Planos Diretores foram elaborados e não aprovados no município de Guarujá, são eles o de 1968, conhecido como Plano Badra; e o de 1986, 
de autoria do urbanista Jaime Lerner, ex-prefeito de Curitiba e atual governador do Paraná.

As razões do insucesso desses projetos, no âmbito do Legislativo, segundo fomos informados por profissionais que trabalharam na área de planejamento da prefeitura local, são atinentes aos interesses do mercado imobiliário. No entanto, é possível que para isso tenha contribuído um descolamento da esfera política, na discussão dos planos diretores, fato recorrente na época, conforme a tese defendida por VILLAÇA.

Ressaltamos, também, que a Lei de Zoneamento, Uso, Ocupação e Parcelamento do Solo de Guarujá, Lei Complementar $N^{\circ}$ 43, de 21 de dezembro de 1998, atualmente em vigor, por encontrar-se fora da periodização proposta para este trabalho, não será objeto de estudo.

Até a promulgação da Lei № 319 , de 3 de dezembro de 1955, que instituiu o Código do Município do Guarujá, a legislação incidente sobre o município era a referente ao seu território, inserida na legislação urbanística de Santos, em vigor na época, conforme dispunha o Ato № 1, de 8 de setembro de 1934. Ou seja, no período imediatamente anterior à promulgação da Lei $N^{\circ} 319$, de 1955, vigorava para o Guarujá, o disposto no Decreto Lei Municipal de Santos № 403, de 1945. Ressalta-se que a legislação santista que tratava do Guarujá possuía especial enfoque nas áreas então ocupadas, como a região conhecida como Bocaina, ou Itapema, atual Distrito de Vicente de Carvalho; e a região da Praia de Pitangueiras.

Na época, a ocupação da área central de Guarujá - na região da atual Praia de Pitangueiras - ainda era muito restrita, mas o Itapema já se constituía em alternativa habitacional para a população de baixa renda, que não tinha condições de habitar em Santos e que possuía vínculos econômicos com o porto, indústrias de Cubatão e setor terciário de Santos.

O Código do Município do Guarujá, sancionado pelo Prefeito Domingos de Souza, era constituído de 106 artigos, distribuídos em duas partes: a Parte Geral, com 28 artigos, divididos em Disposições Preliminares e um Título Único, de quatro capítulos, que tratava de aspectos administrativos da organização do município, como posturas e penalidades. O Título I, da Segunda Parte, denominado "Das medidas de urbanismo, obras e segurança pública", com quatro capítulos, encerrava-se no artigo 106 e é o mais importante para a nossa finalidade.

O artigo 29, do Capítulo I, desta Segunda Parte, estabelecia que a Prefeitura deveria elaborar o "Plano de Urbanismo de Guarujá, tendo em vista as verdadeiras necessidades do Município, e que será parte integrante do seu respectivo Plano Diretor". Os artigos 30 e 31 davam critérios e diretrizes para a elaboração desse plano. O Capítulo II - Do Zoneamento, em seu artigo 32, dividia o território do Município em três áreas: Urbana - ZU, Suburbana - ZS, e Rural - ZR.

A Zona Urbana, por sua vez, era subdividida em cinco bairros: Comercial principal - $\mathrm{BC} 1$, Comercial secundário $\mathrm{BC} 2$, Industrial - BI, Residencial principal - BR1, e Residencial Secundário - BR2. Nos bairros comerciais era vedada a instalação de "hospitais, casas de saúde, indústria pesada e depósito de inflamáveis ou similares". Nestes 
bairros seria tolerada a construção de residências, desde que respeitadas as condições estabelecidas para o BR2.

Nos bairros residenciais seriam também permitidos, "a juízo da Prefeitura", estabelecimentos diversos, como garagens comerciais, postos de abastecimento de veículos, escolas e indústrias leves. O comércio nestes bairros seria admitido em lotes de esquina, ou em logradouros especificados, em decreto, para este fim.

O artigo 47 estabelecia que a "Prefeitura providenciaria, no sentido de serem criados na Zona Suburbana, núcleos de habitações operárias". Esta zona era a área a norte da Serra de Santo Amaro, a região do Itapema, onde se fixara a população de baixa renda. Portanto, o Código de 1955 já continha elementos explícitos de segregação espacial.

A Seção V, do Capítulo II, que dispunha dos critérios para implantação de loteamentos, em seu artigo 66, estabelecia testada mínima de $8 \mathrm{~m}$, e área mínima de $260 \mathrm{~m}^{2}$ para os lotes. No entanto, no artigo 68 era estabelecido que nos núcleos comerciais seria admitida área mínima de $240 \mathrm{~m}^{2}$. $\mathrm{O}$ artigo 73 dispunha dos critérios de parcelamento para a finalidade de construção de "habitação operária de tipo econômico". Nesses casos, seria exigida testada mínima de $9 \mathrm{~m}$ e área mínima de $225 \mathrm{~m}^{2}$. Portanto, a exigência de testada era superior ao que era exigido nos demais casos e a área mínima pouco inferior. Salientamos, porém, que o Código admitia, em casos especiais, a construção de mais de um edifício no mesmo lote.

O artigo 104 estabelecia que nos "lotes cuja testada ou área não permita desmembramento", seria permitida a construção de mais de um prédio nas seguintes condições:
I - Não ultrapassar de três o número de prédios independentes;

II - ser respeitada a taxa de ocupação determinada por este Código para a zona respectiva e os espaços livres acaso determinados para a quadra respectiva $^{103}$

III - formarem um conjunto arquitetônico único, quando geminados num mesmo edifício e dando frente para o logradouro público;

IV - os prédios quando derem para o logradouro público, deverão corresponder, cada prédio, no pavimento térreo, pelo menos $7,50 \mathrm{~m}$ de testada do lote;

V - quando os prédios não forem geminados deverão guardar entre si áreas, cuja dimensão mínima seja igual ao dobro da exigida, por esta Lei para o efeito de iluminação e ventilação;

$\mathrm{VI}$ - nas áreas dos fundos será permitida a construção de muros divisórios, separando os quintais sem que tais muros sejam considerados como constituindo desmembramento".

Dessa forma, a construção de conjuntos geminados era prevista no Código do Guarujá, garantindo, assim, a possibilidade de construção de unidades mais econômicas.

È importante destacar, no entanto, que o estabelecimento de recuos mínimos e número máximo de pavimentos ${ }^{104}$ só

\footnotetext{
${ }^{103}$ No entanto, não há definição de índices urbanísticos no Código. Tal providência somente ocorreu posteriormente, por meio de legislação ordinária regulamentadora.

${ }^{104}$ Esta lei estabelecia em 16 o número máximo de pavimentos e área mínima de $250 \mathrm{~m}^{2}$ para lotes em novos parcelamentos e desmembramentos.
} 
veio a ocorrer posteriormente, pela Lei № 463, de 9 de junho de 1960. O aproveitamento máximo do lote foi estabelecido apenas em 1961, pela Lei № 531, de 9 de janeiro $^{105}$.

Apenas em 1966, pela Lei № 854, de 1ำ de setembro, foi admitida a construção de edifícios de quatro pavimentos sem elevador, permitindo uma nova tipologia que diferia da dos edifícios de veraneio - que possuíam grandes dimensões e permitiam grande densidade - que marcaram a ocupação da área central do Guarujá. Esta tipologia pode ser encontrada ao longo da orla marítima da Praia da Enseada, ocupada a partir do final da década de 60 , do século XX.

Portanto, pode-se identificar no Código do Guarujá, e suas posteriores alterações, elementos semelhantes aos contidos na legislação urbanística dos demais municípios centrais da RMBS no mesmo período, com exceção de Cubatão. São estes, a preocupação em permitir o desenvolvimento da atividade imobiliária, baseada na construção de unidades de veraneio na orla marítima, auferindo dos terrenos nela localizados o rendimento máximo, bem como a intenção explícita de estabelecer territórios segregados para a população de baixa renda.

Da mesma forma, quando se trata de estabelecer critérios para a promoção de empreendimentos voltados a este segmento da população, os condicionantes urbanísticos são na maioria das vezes extremamente exigentes, sobretudo

\footnotetext{
${ }^{105}$ Esta lei eliminava a restrição em número de pavimentos, quando não houvesse disposição explícita nesse sentido, desde que observados $40 \%$ de taxa de ocupação e seis vezes a área do lote de
} aproveitamento. quando se trata de estabelecer áreas mínimas de lotes incompatíveis com a realidade dos rendimentos dessas classes sociais.

A Lei № 1.266, de 24 de dezembro de 1975, que instituiu o Plano Diretor Físico do Município do Guarujá, sancionada pelo Prefeito Raphael Vitiello, continha 259 artigos, distribuídos em quatro títulos. O primeiro dispunha da Conceituação Geral, como nomenclatura e organização do Plano; o segundo tratava dos Elementos do Plano Diretor Físico, como a divisão do Município em áreas integradas urbana, expansão urbana, de interesse urbano e rural, sistema viário, ocupação do solo urbano, paisagismo e conservação dos logradouros; o terceiro dispunha da revisão periódica do Plano, fiscalização e penalidades; e o quarto estabelecia suas disposições finais e transitórias.

Ao comparar-se esse Plano com a legislação urbanística dos demais municípios centrais da RMBS no mesmo período, torna-se evidente o grau de detalhamento do mesmo, até mesmo se for considerado o Plano Diretor Físico de Santos, de 1968. A década de 70 foi para Guarujá a consolidação do padrão de grande crescimento demográfico, verificado a partir da inauguração da Via Anchieta. Era preciso, pois, disciplinar com bastante rigor a ocupação do Município, no momento em que este já passava a enfrentar problemas ambientais e sociais de maior gravidade.

O artigo $8^{\circ}$ revelava o grau de preocupação do legislador: "O Plano Diretor Físico deste Município tem como finalidade assegurar o desenvolvimento físico racional da estrutura urbana, capacitando-a a atender plenamente às funções de habitar, trabalhar, circular e recrear, proporcionando 
também à população um ambiente propício 'a vida social equilibrada e sadia".

O conceito de área urbana adotado pelo Plano, no Capítulo I, do Título II, era idêntico ao de São Vicente, no mesmo período, ou seja, reproduzia-se o artigo 32 do Código Tributário Nacional. O Capítulo II deste mesmo título tratava da estrutura viária e introduzia a possibilidade de implantação de vias-parques, procurando permitir a adoção de um padrão urbanístico tipicamente modernista.

O Capítulo III, do Título II, dispunha da Ocupação do Solo Urbano, e estabelecia sobre critérios de urbanização e parcelamento de glebas e terrenos. $\mathrm{O}$ artigo 64 vedava a ocupação de "terrenos pantanosos ou sujeitos a inundações, antes de executados, por parte dos interessados, os necessários serviços de aterro e drenagens (...)". No entanto, a ocupação de várzeas e mangues em Guarujá, não exclusivamente, mas sobretudo pela população de baixa renda, tornou-se um problema sócio-ambiental de proporções alarmantes nos anos seguintes.

De fato, havia uma grande preocupação do legislador com a ocupação de áreas ambientalmente frágeis. O artigo 67 dispunha da obrigatoriedade de reservar áreas non aedificandi, em fundos de vales, estabelecendo-se uma relação entre as dimensões destas áreas, das bacias hidrográficas e das vias públicas.

No artigo 120, no mesmo capítulo, foi estabelecido o novo zoneamento de uso e ocupação do solo do Município. Adotou-se um padrão de divisão das áreas urbana e de expansão urbana em zonas, segundo os usos e densidades permitidos para as mesmas. Foram criadas, ao todo 34 zonas.

As oito primeiras eram de natureza residencial: Zona Residencial de Baixa Densidade - ZR1; Zona de Expansão Residencial de Baixa Densidade - ZER1; Zona Residencial de Média Densidade - ZR2; : Zona de Expansão Residencial de Média Densidade - ZER2; Zona Residencial de Baixa Densidade - ZR3; Zona de Expansão Residencial de Baixa Densidade - ZER3; Zona Residencial de Alta Densidade - ZR4 e Zona de Expansão Residencial de Alta Densidade - ZER4. Criou-se, ainda, a Zona Especial do Pae-Cará - ZR5.

As onze zonas seguintes eram de natureza comercial: Zona de Comércio Local - ZC1; Zona Expansão de Comércio Local - ZEC1; Zona de Comércio Variado - ZC2; Zona de Expansão de Comércio Variado - ZEC2; Zona de Comércio Pesado - ZC3; Zona de Comércio Intenso - ZC4; Zona de Comércio e Equipamentos - ZC5; Zona Comercial Residencial Tipo Um - ZCR1; Zona de Expansão Comercial Residencial Tipo Um - ZECR1; Zona Comercial Residencial Tipo Dois - ZCR2; e Zona de Expansão Comercial Residencial Tipo Dois - ZECR2.

As últimas quatorze zonas eram de natureza turística, paisagística e ambiental: Zona de Turismo Tipo Um - ZT1; Zona de Expansão de Turismo Tipo Um - ZET1; Zona de Turismo Tipo Dois - ZT2; Zona Especial das Praias - ZE01; Zona Especial do Morro do Maluf - ZE02; Zona Especial do Morro do Estefano - ZE03; Zona Especial do Tejereba ZE04; Zona Especial do Morro das Galhetas - ZE05; Zona Especial da Península - ZE06; Zona Especial do Jequitimar - ZE07; Zona Especial do Jóquei-Golf - ZE08; Zona 
Especial do Horto Florestal - ZE09; Zona Especial do Passeio Público - ZE10; e Zona Especial para Expansão ZE11.

O Capítulo IV, do Título II, dispunha do Uso do Solo Urbano, segundo classificação de usos estabelecida em tabela anexa, em que eram detalhados vários níveis de uso residencial, comercial, prestação de serviços, industrial e institucional. Em outra tabela estabeleceu-se a relação entre cada zona, os usos e os índices urbanísticos permitidos.

Nas zonas residenciais o aproveitamento máximo permitido seria de duas vezes a área do lote, na ZR2 - área da várzea do rio Santo Amaro, ao longo dos eixos das avenidas Ademar de Barros e Santos Dumont ${ }^{106}$ - e na Zona Especial do Morro do Maluf, no limite entre as praias de Pitangueiras e Enseada, poderia alcançar as 5 vezes, em terrenos entre a cota 0 e $10 \mathrm{~m}$. A área mínima de lote admitida seria de $250 \mathrm{~m}^{2}$, em várias das zonas residenciais e comerciais. Os recuos frontais permitidos nestas zonas seriam de, no mínimo, $5 \mathrm{~m}$.

No artigo 127 foi detalhada a área de interesse urbano, a qual foi dividida em sete setores, segundo sua localização, com usos variados como atividades portuárias, projetos habitacionais, pesquisa científica, área militar e outros. Os setores eram áreas normalmente sem conexão direta com a

${ }^{106} \mathrm{Na}$ verdade, o eixo da avenida Ademar de Barros - que liga o centro da cidade à estação das balsas para Santos, o Ferry Boat - fo classificado como ZC1 e ZC2 (ver Figura 41). Já a área ao longo da avenida Santos Dumont, majoritariamente classificada como ZR2, corresponde ao distrito de Vicente de Carvalho. malha urbana, em que se queria incentivar determinadas atividades, conforme a vocação do local.

No artigo 137 eram previstos índices mínimos para a construção de casas de madeira, semelhantes aos adotados em Santos e São Vicente. Estabelecia-se afastamentos laterais de $2 \mathrm{~m}$ e de $4 \mathrm{~m}$ em relação a qualquer outra casa de madeira. Eram também permitidas edificações conjugadas, em número máximo de duas.

Portanto, o Plano de 1975 não previa, salvo na exceção da ZE02, áreas com adensamento semelhante ao permitido em Santos, na mesma época. O nível de detalhamento em função dos usos permitidos, no entanto, chegava a ser maior, pois eram previstos espaços com níveis variados de integração entre áreas residenciais e comércio e prestação de serviços.

Ao mesmo tempo, tal como ocorreu com a Zona Noroeste o grande território popular de Santos - na mesma época, as áreas de Vicente de Carvalho e as próximas ao Ferry Boat, no bairro Santa Rosa, tiveram seu aproveitamento limitado por índices inferiores aos permitidos na região mais valorizada da orla. A exceção era a Praia de Enseada, cujo trecho entre o oceano e a avenida $D$. Pedro I foi classificado como ZR1 e, portanto, só admitia residências unifamiliares $^{107}$ (ver Figura 41). O trecho da orla da Enseada entre esta avenida e a Serra de Santo Amaro foi

\footnotetext{
$107 \mathrm{Na}$ verdade, fez-se a tentiva de transformar a região da Enseada, nas primeiras quadras próximas ao mar, numa área exclusivamente de residências de alto padrão, nos moldes dos Jardins, na Capital. No entanto, a Municipalidade, por meio da Lei $N^{\circ} 1.421$, de 1979, cedendo aos interesses do segmento da promoção imobiliária, possibilitou maior adensamento nesta área, com o padrão de edifícios de quatro pavimentos, que hoje predomina em toda a região da Enseada.
} 
classificado como ZR2, tendo assim definido um padrão urbanístico semelhante ao de Vicente de Carvalho e bairro Santa Rosa.

A questão da habitação popular, porém, não foi objeto de preocupação desse Plano. Foi apenas pela Lei № 1.313, de 8 de novembro de 1976, que o tema passou a ser objeto de legislação específica, em Guarujá. Esta lei visava permitir a alteração dos índices urbanísticos, em determinadas áreas, para que fossem implantados "Conjuntos Habitacionais para moradia do tipo popular, cujas inversões financeiras sejam provenientes ou autorizadas pelo Banco Nacional da Habitação ou obedeçam a política do Sistema Nacional de Habitação".

Em tabela anexa à lei, fixava-se a área mínima de lote, para edificações uni-habitacionais, em $150 \mathrm{~m}^{2}$, com testada mínima de $7,5 \mathrm{~m}$ e taxa de ocupação de $40 \%$ a área do lote. Para essas unidades os recuos mínimos admitidos seriam de $5 \mathrm{~m}$, frontal; $1 \mathrm{~m}$, lateral; e $3 \mathrm{~m}$, nos fundos. Apesar de serem índices ainda insuficientes para possibilitar maior economia na construção popular, estes novos dispositivos representavam um avanço significativo, em relação ao Plano de 1975.

No entanto, essa mesma lei serviu aos interesses do setor imobiliário, que pressionava pela ampliação da possibilidade de adensamento nas áreas mais valorizadas do núcleo central da cidade, junto à orla da Praia de Pitangueiras. Foi assim que o coeficiente de aproveitamento na ZCR1 - área delimitada pelo oceano e morros da Campina, Botelho e da Glória - subiu para 5 vezes a área do lote.
Em 1979, pela Lei № 1.421, de 30 de abril, sancionada pelo Prefeito Jayme Daige, foi alterado o zoneamento de uso, estabelecendo-se onze zonas para todo o município. Eram elas: Zona de Alta Densidade - ZAD; Zona de Média Densidade 1 - ZMD1; Zona de Média Densidade 2 - ZMD2; Zona de Baixa Densidade 1 - ZBD1; Zona de Baixa Densidade 2 - ZMD2; Zona de Serviços - ZS; Zonas Verdes - ZV; Zonas Especiais - ZE; Zona Industrial - ZI; Zona Portuário/Industrial - ZPI; e Zona de Preservação Ecológica - ZPE.

$\mathrm{Na} Z A D$, o coeficiente de aproveitamento foi fixado em 5 vezes a área do lote e o número máximo de pavimentos em 17 , mais o térreo. Os usos admitidos, além do residencial uni e multifamiliar, eram comércio varejista de pequeno porte, supermercados e serviços de caráter geral, como escritórios, bancos, cinemas, hotéis e outros.

Na ZMD1, o coeficiente de aproveitamento foi fixado em 2 vezes a área do lote e o número máximo de pavimentos em 4 mais o térreo, com elevador, ou 2 mais o térreo, sem elevador. Os usos admitidos, além do residencial uni e multifamiliar, eram comércio varejista de pequeno e médio portes e serviços de caráter geral como na ZAD, e outros de caráter mais impactante como editoras, tipografias e gráficas.

Na ZMD2, o coeficiente de aproveitamento foi fixado em 2 vezes a área do lote e o número máximo de pavimentos em 4 mais o térreo, com elevador. Os usos admitidos, além do residencial uni e multifamiliar, seriam comércio varejista de pequeno e médio portes e serviços de caráter geral. 
$\mathrm{Na}$ ZBD1, o coeficiente de aproveitamento foi fixado em uma vez a área do lote e o número máximo de pavimentos em dois. Os usos admitidos seriam: residencial unifamiliar, em edifícios isolados, em série, geminados ou superpostos; comércio varejista de pequeno porte ou supermercado; e serviços de caráter geral.

$\mathrm{Na}$ ZBD2, o coeficiente de aproveitamento foi fixado em uma vez a área do lote e o número máximo de pavimentos em dois. Os usos admitidos seriam: residencial unifamiliar, em edifícios isolados; estabelecimento de ensino e cultura; e estacionamento e garagens coletivas.

Dessa maneira, fica clara a intenção de dividir socialmente o território municipal. De forma distinta a Santos, que simplesmente vedou a construção de moradias em série ou sobrepostas, pelo Plano Diretor de 1968, a legislação de Guarujá delimitava uma área onde as tipologias habitacionais acessíveis à baixa renda poderiam ser edificadas $^{108}$. O maciço de morros da Serra de Santo Amaro consolidou-se, assim, como o divisor social da Guarujá rica, na orla; e da pobre, em Vicente de Carvalho.

$\mathrm{Na}$ orla fixou-se um padrão de alta densidade junto ao centro, em Pitangueiras, com edifícios de veraneio e comércio variado; e de média e baixa densidade nas demais praias (ver Figura 43). As atividades de maior impacto ficaram restritas ao pólo portuário de Conceiçãozinha, em Vicente de Carvalho, e aos principais eixos viários dos bairros mais distantes da orla, no noroeste da ilha.

\footnotetext{
${ }^{108}$ Em Santos, essa limitação se dava, sobretudo, pela tolerância às restrições impostas pela legislação.
}

É interessante notar que, tanto o Plano de 1975, como a Lei № 1.421, de 1979, dispunham de um critério bastante subjetivo no tocante aos usos admitidos em cada zona. Foram criadas duas categorias: os usos permitidos e os permissíveis. Os primeiros são os que foram relacionados acima. Os demais são atividades que poderiam estabelecer-se nas zonas, conforme a "conveniência" para a Municipalidade. É o caso, por exemplo, de boates, padarias, manufaturas não incômodas, clubes e outros, na ZAD.

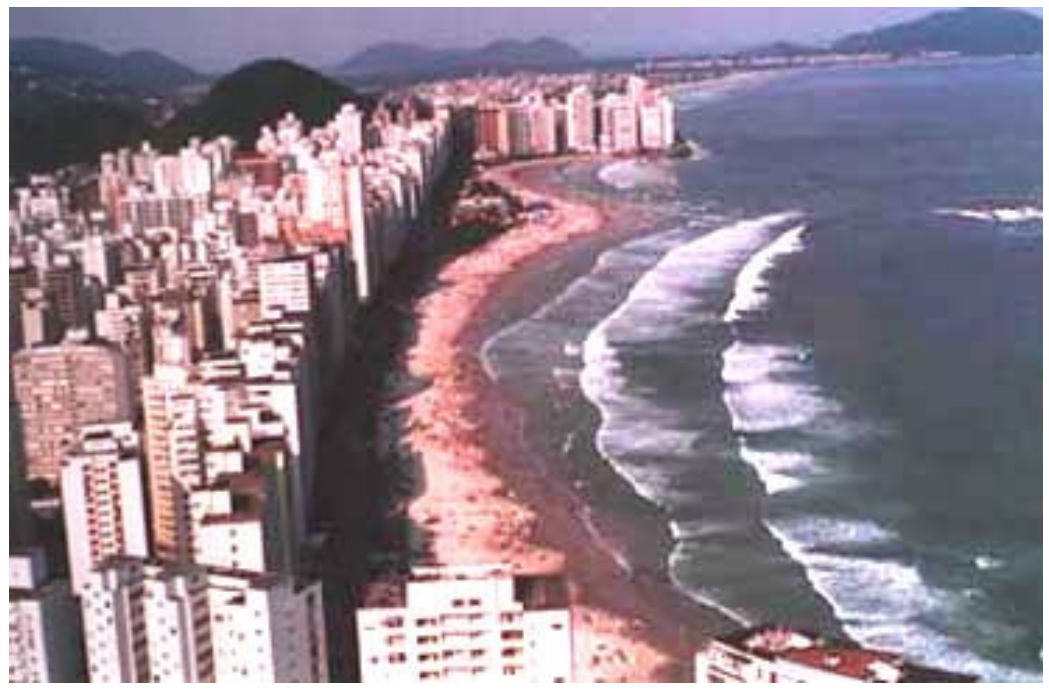

Figura 43 - Muralha de edifícios na orla marítima de Pitangueiras. Ao fundo vê-se a Praia de Enseada, com padrão urbanístico de média densidade, onde predominam edifícios de 4 pavimentos e residências uni-familiares de veraneio. Fonte: sítio da Prefeitura Municipal de Guarujá na rede mundial de computadores www.guaruja.sp.gov.br - 2001. 
Em 11 de novembro de 1980, foi sancionada a Lei № 1.521, que estabelecia índices urbanísticos especiais para o Sítio Pai Cará. O Pai Cará, o assentamento subnormal mais antigo da Baixada, é uma área de propriedade do Estado, onde se fixaram famílias de baixa renda provenientes de Santos, no começo do século, com vínculo na atividade portuária.

A Prefeitura, por meio desta lei pretendia criar condições mais favoráveis para a implantação de um projeto de urbanização. Para tal fim, passou a admitir área mínima de lote de $125 \mathrm{~m}^{2}$ e testada mínima de $7 \mathrm{~m}$. Em "casos excepcionais, para evitar a necessidade de remoção onerosa", seriam admitidas área mínima de $90 \mathrm{~m}^{2}$ e testada mínima de $6,5 \mathrm{~m}$.

Essa foi, na breve história do Município do Guarujá, a primeira tentativa de enfrentar a questão da falta de condições habitacionais, para a população de baixa renda, por meio de sua fixação no próprio local da ocupação original.

Na virada da década de 80 , as condições de moradia para a baixa renda em Guarujá já eram preocupantes. No entanto, ao longo dessa década, com o incremento da atividade imobiliária vinculada ao turismo balneário, o fluxo de mãode-obra de baixa qualificação intensificou-se, tornando este município o líder, dentre os municípios centrais da RMBS, em números absolutos de residentes em condições habitacionais precárias. 
Legislação urbanística e segregação espacial nos municípios centrais da Região Metropolitana da Baixada Santista

5. A evolução do valor imobiliário em Santos 
Legislação urbanística e segregação espacial nos municípios centrais da Região Metropolitana da Baixada Santista 
Como se pôde verificar pela análise de algumas obras em que a questão da segregação espacial foi tema central, como em MARICATO (1996), VILLAÇA (1998), e ROLNIK (1997), o fenômeno da segregação espacial em nossas metrópoles é decorrente da estrutura social e econômica brasileira, na qual a população de menor renda vive em condições apenas suficientes para sua reprodução.

Essa condição, mascarada pelo discurso ideológico, manifesta-se no espaço urbano com a formação de territórios duais. São estes territórios os espaços das classes privilegiadas, de altos e médios rendimentos, e os das classes populares, de baixos rendimentos.

As primeiras aglutinam-se em parcelas minoritárias do território das metrópoles, atraindo para essas localizações a parte mais significativa dos investimentos públicos, construindo em torno de si uma satisfatória e, por vezes, redundante rede de infra-estrutura e serviços. As classes de menor renda espalham-se pelo restante do território, sem condição que lhes permita residir nas localizações dotadas de infra-estrutura e serviços em nível adequado.

Dentre essas, as populações mais pobres acabam por habitar, na maior parte das vezes, áreas degradadas ambientalmente. São espaços de difícil acessibilidade, desprovidos de serviços públicos essenciais, tendo como característica uma situação fundiária invariavelmente irregular.

Como também apontou VILLAÇA e foi possível verificar pela leitura dos trabalhos de ANDRADE (1989), CALDATTO (1998), LANNA (1996), NUNES (2001), SEABRA (1979) e SERRANO (1991) - que focalizaram aspectos da evolução urbana de Santos e outros municípios da RMBS, em diferentes períodos - nas metrópoles litorâneas este fenômeno é mais evidente, em função do grande poder de atração da orlas marítima, sobre as classes sociais de alta renda.

Em VILLAÇA (1998: 157) pode-se ler: "Em todas as áreas metropolitanas - e mesmo nas cidades médias litorâneas brasileiras com praias de alto-mar, com exceção de Salvador -, as orlas estão sendo crescentemente ocupadas pelas camadas de mais alta renda: Balneário Camboriú, Santos - São Vicente - Guarujá, Rio - Niterói, Vitória, Recife, Fortaleza, etc" (grifo do autor).

Aplicando o modelo de setores de circulo, de Homer Hoyt, VILLAÇA (1998: 113-116) evidenciou a forma como as classes sociais se distribuem nos territórios de várias metrópoles brasileiras. No caso das metrópoles litorâneas, em que a ocupação do território desenvolve-se em $180^{\circ}$ - a exemplo de Rio-Niterói - ficou clara a preferência da alta renda pela orla (ver Figura 44).

Nos municípios centrais da RMBS este fenômeno também ocorreu de forma similar. Em Santos-São Vicente-Guarujá pode-se adotar configuração de setores circulares semelhante à de Rio-Niterói, no tocante à localização da alta renda. Como se pode ler nas obras dos autores citados, no caso da Baixada Santista esse fenômeno desenvolveuse ao longo do século XX, embora no final do século XIX a alta renda paulista já fosse detentora de terrenos junto às orlas marítimas de Santos e Guarujá. 


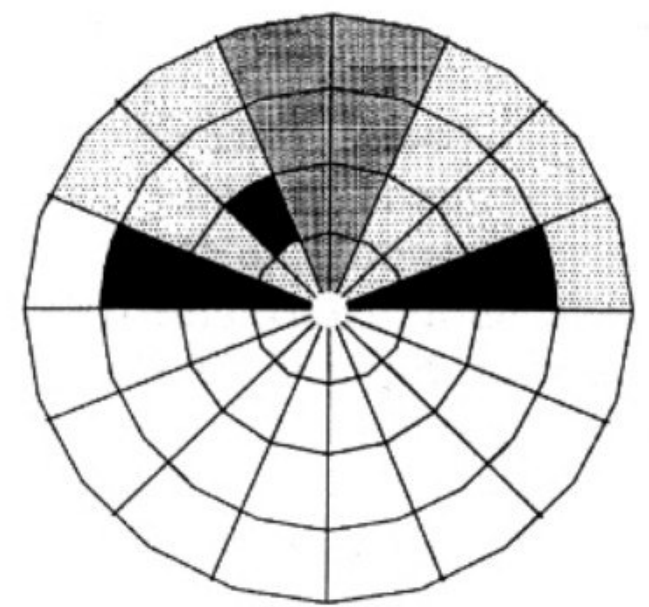

Rio de Janeiro (inclusive Niterói)

\section{Legenda}

NREAS RESOENCWS DAS CAMUAN DE RENOA NWS NLTA
OUTRUS AREAS RESIDENCWS
CREAS INDUSTRWS
CENTRO

Figura 44 - Estrutura espacial da área metropolitana do Rio de Janeiro, incluindo Niterói, segundo o modelo de Hoyt, apud VILLAÇA (1998: 115).

Em ANDRADE (1989: 200), com referência ao período da virada do século XIX para o XX, pode-se ler: "A orla da praia tornou-se área perfeita para a construção de residências abastadas, as chamadas 'mansões da praia'". Mais adiante (1989: 203), a autora salientou que o padrão urbanístico desses lotes na orla já era diferenciado, com grandes frentes e profundidades. Na mesma obra (1989: 160), a autora apresentou a interessante transcrição de alguns anúncios de imóveis localizados na orla, nos periódicos da época, que demonstraram a crescente preferência das classes de alta renda por essa localização.

ANDRADE (1989: 220-221) ressaltou, ainda, a mais importante alternativa de moradia da baixa renda no início do século $X X$, o chalé de madeira, lembrando que, "o chalé, pela necessidade das classes populares, acompanhou a expansão de Santos, em direção à praia; expulsos pela Comissão Sanitária, pelas epidemias do porto, pelos altos aluguéis do centro, os trabalhadores procuraram algum lugar para morar. Entre o centro e a orla marítima, Barra, Gonzaga, José Menino, havia vasta área plana, coberta de capinzais. Os terrenos abundantes e baratos eram vendidos em prestações ou mesmo alugados" (grifo do autor).

A autora destacou, também, que os chalés não existiam ao longo das avenidas Conselheiro Nébias e Ana Costa, no Centro e muito raramente nos bairros periféricos a este. Segundo ANDRADE (1989:225), “(...) sua multiplicação (referindo-se aos chalés) mostrou que houve, a nível popular, uma acumulação do tipo capitalista que explica sua existência, reprodução e melhoria".

Sobre as dimensões dos lotes em que os chalés eram edificados ANDRADE (1989: 224), afirmou que geralmente possuíam entre 7 e $8 \mathrm{~m}$ de frente e $30 \mathrm{~m}$ de fundo, podendo apresentar algumas variações, para mais ou para menos.

A respeito da localização das classes sociais, na virada do século, ANDRADE (1989: 174) escreveu: "Evidencia-se que havia um enorme vazio entre a cidade e a Barra, que foi sendo preenchido aos poucos. Enquanto isso, a Barra ia sendo ocupada espaçosamente, por casas e chácaras, numa expansão nada tímida. 
Essa ocupação teve uma divisão social marcada: os abastados moravam nas chácaras, chalés elegantes e mansões - citando GOMES (1984: 55) - os de classe média ocupavam os bairros mais próximos da cidade: Vila Mathias e Vila Macuco".

No final do século XIX, primeiramente a população de alta renda deixou o Centro para residir no bairro vizinho, o Paquetá. Poucas décadas depois, este mesmo extrato social passou a ocupar a Vila Nova, também próxima ao Centro. A partir desse momento, com a possibilidade de ocupação da planície mais próxima à orla - devido às obras de saneamento e drenagem associadas às obras viárias e à extensão do sistema de transporte por bondes - as classes de maior renda foram abandonando aqueles bairros para viver mais próximas às praias.

Nesse período, os eixos das avenidas, sobretudo da Conselheiro Nébias e da Ana Costa, tornaram-se, localizações preferenciais da alta renda. Daí o motivo de nestas não se encontrar registros de construção de chalés. A valorização dos terrenos ao longo das avenidas, em função das obras viárias e do serviço de bondes, segundo ANDRADE (1989: 165), foi logo percebida pelos empresários do segmento imobiliário, que abriram novas chácaras e lotearam as que ficavam próximas ao centro como foi o caso de Vila Nova, Vila Mathias e Vila Belmiro.

Cabe ressaltar que a Vila Mathias é o maior bairro de Santos, atravessando toda a zona leste da área insular do município. Por isso não é surpreendente a ocorrência de registros aparentemente contraditórios na obra de ANDRADE (1989: 161 e 174), em relação às classes sociais que ocuparam este bairro. Na realidade, em função de sua grande extensão, havia na Vila Mathias, terrenos próximos aos principais eixos viários, bastante valorizados, e outros em localizações menos favorecidas, onde parte da baixa renda se estabeleceu, na virada do século, como os próximos ao porto.

$\mathrm{Na}$ obra de SEABRA (1979) encontra-se importante contribuição para 0 entendimento do processo de valorização da orla marítima, no Período Desenvolvimentista - mais especificamente, entre a abertura da Via Anchieta e o final da década de 60 - que permitiu a explosão da construção de edifícios de apartamentos de veraneio na orla santista, num espaço de cerca de quinze anos.

Essa autora, analisando o setor da construção civil, que em Santos guardava estreita e simbiótica relação com a promoção imobiliária, evidenciou como as características particulares dos imóveis localizados junto ao mar, em determinadas condições, revolucionaram 0 mercado imobiliário da cidade, produzindo um paredão de edifícios que marcou esse período em sua paisagem de forma indelével.

A leitura dessa obra é suficiente para que se possa entender o real significado do mar como referencial de valorização do solo. Para melhor estudar esse fenômeno e compreender suas particularidades, no espaço e no tempo, a autora perfez, no item 3.2 - O processo de valorização do solo (1979: 82-98) - importante caminho reflexivo. Esse caminho facilitou a compreesão do mecanismo de valorização do solo, e permitiu a avaliação de sua possível relação com a regulação urbanística, no sentido de verificar se esta contribui ou não, de forma efetiva, para a produção 
do fenômeno da segregação espacial - objeto central desta pesquisa.

A partir desse patamar aprofundou-se a análise dos aspectos conceituais, que são essenciais para a compreensão desse mecanismo. Em seguida, foi avaliada a questão do valor do solo, com especial enfoque no caso de Santos, no Período Desenvolvimentista. 


\subsection{Valor imobiliário - o caso de Santos}

Escreveu SEABRA (1979: 82): "O solo tem um preço. Esse preço é a medida concreta da sua valorização". Em seguida, citando JUILLET (1971), a autora completou: "O preço da terra é o montante capitalizado da renda fundiária". Ou seja, o valor da terra varia com o tempo, geralmente de maneira crescente, conferindo ao seu proprietário uma renda, que é o "tributo que se paga ao direito de propriedade (...)".

Mais adiante, a autora lembrou que o preço do solo varia com o tempo, "em função da produção social, a qual de alguma forma está articulada com a terra". Essa variação seria também espacial, pois é afetada por certos aspectos peculiares de cada localização.

Assim, pode-se dizer que há na formação do valor imobiliário do solo dois componentes básicos, um de ordem física, por exemplo, a vista para o mar, o relevo do terreno; outro de ordem social, como a existência de determinados equipamentos urbanos, maior ou menor acessibilidade e etc. No caso da orla de Santos, efetivamente a paisagem, a fruição da praia, a acessibilidade e a implantação de um pólo de serviços - o Gonzaga, no primeiro momento - são estes componentes.

Nesse município, como será possível observar no estudo que será apresentado adiante, comparando valores unitários de diferentes áreas de sua parte insular, esses fatores influenciaram claramente a valorização da orla. Assim, esta exclusividade da vista do mar e da fruição da praia, aliados à infra-estrutura e acessibilidade possibilitadas pela urbanização da Zona Leste, tornaram-se elementos definidores do alto valor imobiliário, em contraponto à região central, em que o porto suprimiu o contato com o mar, e o patrimônio imobiliário obsoleto, devido a um padrão de parcelamento em lotes de pequenas dimensões, representava obstáculo à atividade imobiliária.

Com especial interesse para este trabalho, SEABRA (1979: 84) apontou ainda questão de fundamental importância, que denominou "estratificação de usos possíveis do solo, a qual é em princípio definida por uma divisão social do espaço". Ou seja, "o uso possível é sempre aquele que confere ao solo o maior preço. Ou se quiser, aquele que confere aos proprietários da terra a máxima renda". Esta afirmação é, sem a menor dúvida, a chave da compreensão do mecanismo que se pretende compreender: uso do solovalorização-exclusão.

Em seguida, de forma taxativa, SEABRA arrematou: "É em função de um uso que se vislumbra como possível que se definem as modalidades de uso do solo". Não por acaso, ao ser estudada a legislação urbanística de Santos, São Vicente e Guarujá pôde-se verificar que a duração da legislação urbanística era sempre definida pela necessidade de moldar esta regulação aos interesses do mercado imobiliário.

Assim, quando a abertura da Via Anchieta descortinou para milhões de paulistas, a possibilidade de passar fins-desemana a beira-mar e o mercado imobiliário vislumbrou a oportunidade de realizar lucros imensos verticalizando as propriedades junto às praias, um a um, como dominó, foram alterados índices urbanísticos e classificações de usos, permitindo a plena realização desses lucros. 
O estudo de SEABRA revelou, também, outro fator importante, em referência à questão dos usos. Mesmo em relação a outros terrenos localizados na orla, aqueles onde a atividade terciária encontrava melhores condições para desenvolver-se - Gonzaga, em Santos e Pitangueiras, no Guarujá - eram sempre mais caros. SEABRA chegou mesmo a estabelecer uma hierarquia de valor, conforme o uso potencial. Segundo essa hierarquia, o uso terciário é sempre o mais valorizado, seguido pelo residencial e por último, pelo industrial.

SEABRA (1979: 85) concluiu que "a valorização diferencial do solo pode ser tomada como expressão do conteúdo histórico da ocupação, em que se combinam um processo geral de valorização da terra com as particularidades de cada localização específica, em termos de poder suportar esse ou aquele tipo de atividade".

Apropriando-se de dados do setor imobiliário, compilados da imprensa e complementados por elementos extraídos das plantas de valores genéricos, SEABRA (1979: 85-89) traçou importante painel do comportamento do mercado imobiliário na orla, no período entre 1945 e 1976.

Verificou-se pela leitura desse trabalho que a lucratividade na venda dos terrenos destinados aos empreendimentos imobiliários de veraneio na orla de Santos cresceu durante os primeiros dez anos, após a abertura da Via Anchieta, tendo declinado, atingindo, em meados da década de 60 , um ponto em que a lucratividade era muitíssimo menor do que foi no início da década de 50. Segundo SEABRA, a alta lucratividade nesses primeiros anos explica porque, em Santos, vários proprietários de terrenos e empresas de outras atividades lançaram-se no ramo da construção.
Percebe-se, ainda, como o valor dos terrenos, inicialmente mais altos em sertos bairros da orla, como o José Menino por exemplo, tenderam a igualar-se com os dos demais bairros dessa área, com exceção do Gonzaga, cujo diferencial era o de ser um pólo terciário da orla.

No aspecto do preço do metro quadrado dos terrenos da orla, a autora apresenta gráfico de sua variação média no período em tela, revelando que este oscilou de 200 cruzeiros em 1945, a cerca de 3.000 cruzeiros em 1975, aplicando-se o fator de correção monetária do IGP, coluna 2, da Fundação Getúlio Vargas (1979: 96). Entretanto, no período entre 1950 e 1970, o preço do metro quadrado das construções de apartamentos de veraneio decresceu de 1.000 cruzeiros para cerca de 400 cruzeiros.

SEABRA apontou, também, outro fato interessante (1979: 91): "Em Santos, (no período estudado) comprava-se terreno muito mais barato do que em localizações valorizadas de São Paulo, em que se podiam produzir edifícios, e vendiam-se os apartamentos a preços muito próximos aos de São Paulo". Ora, essa é uma constatação essencial para compreender-se como o caráter de região de veraneio, marcada pela produção de unidades de segunda residência, tornou inacessível, sobretudo nas décadas de 50 e 60, para as classes de menor renda - e mais generalizadamente para a população local - estabeleceremse junto à orla.

Conforme a citada autora relatou, a partir da década de 70 essas unidades tornaram-se mais acessíveis e passaram a ser ocupadas pela população local de média e alta rendas. Nesse período em Santos houve um fenômeno particular, que foi o da ocupação de unidades de quarto e sala 
conjugados, as chamadas kitchenetes, por população de média renda. Nesse momento, Guarujá já havia se tornado a opção preferencial para a produção de unidades de segunda residência, no litoral central do estado.

Ao estudar a formação do valor da terra, SEABRA abordou a questão do monopólio, baseando-se na conceituação marxista, expressa no Livro III do Capital. Segundo MARX, o proprietário tem 0 poder do monopólio sobre sua propriedade, o que é reforçado pelo fato de não existirem dois terrenos com características iguais. SEABRA (1979: 93) afirmou: "(..) ao transacionar com a terra, as características específicas, inerentes a ela é que levam seus proprietários, individualmente e em conjunto, a exigir um preço para a terra em função de como socialmente está ela valorizada. O poder de monopólio não geraria então, automaticamente uma renda de monopólio".

Assim, segundo MARX (1946), o preço da terra pode subir em função do que é possível dela se obter, ou ainda: "a renda de monopólio não é determinada pelo preço de produção ou pelo valor da mercadoria, mas pelas necessidades e pela capacidade de pagar dos compradores".

Outros aspectos importantes podemos obter da análise da obra de WELCH (1941), autor norte-americano e perito em avaliações de relevo na primeira metade do século $X X$, que contribuiu ao debate sobre o tema, ao discorrer sobre os diferentes tipos de valor imobiliário, o que é essencial para que possamos compreender a pertinência da utilização das plantas genéricas de valor, para o presente estudo.
WELCH (1946: 3-12) distinguiu os seguintes tipos de valor, ou de preço - termo que também utilizava: "valor de mercado", ou "de troca"; "valor taxável"; "preço reservado"; "preço garantido"; e "valor normal". A despeito dessa grande quantidade de conceitos, segundo o autor, a escolha de um criterioso processo de avaliação passa necessariamente pela aplicação dos métodos básico e derivado, para elaboração de uma planta confiável.

Segundo WELCH, o "valor de mercado" é aquele pelo qual o proprietário poderia obter pelo imóvel, caso dispusesse de um lapso normal de tempo para negociar o mesmo e que, ainda, o comprador tivesse ampla oportunidade de examinar este imóvel, comparando-o com imóveis semelhantes, disponíveis.

O "valor taxável" era, na verdade, a forma de avaliação adotada por cada estado norte-americano, naquela época. Esta forma variava dentre os demais tipos de valores definidos por WELCH. O "preço reservado" era o preço mais baixo, pelo qual um proprietário negociaria seu imóvel. O "preço de garantia" era "o preço máximo que um comprador, tendo plena visão e motivado somente por considerações econômicas, pagaria por uma propriedade, e o preço mínimo que um vendedor, igualmente dotado e motivado, aceitaria, pela sua propriedade". O "valor normal", muito criticado por WELCH, por possibilitar avaliações duvidosas, era a média aritmética de "valores passados", tomados como base para a predição de valores futuros.

Assim, a construção e a crítica desses conceitos, formou o pensamento de uma geração inteira de técnicos. Como será visto adiante, esses conceitos, sobretudo a importância atribuída ao "método comparativo", foram decisivos para a 
forma de elaboração das plantas genéricas dos municípios centrais da Baixada Santista e mais especificamente para as de Santos.

Em relação a Santos, como será evidenciado em seguida, procurou-se compreender em que medida as classes sociais, de forma articulada, moldaram determinados territórios das cidades. Especificamente verificou-se a que ponto os mesmos interesses imobiliários que determinaram a valorização dos terrenos da orla atuaram no sentido de construir uma regulação urbanística voltada a seus interesses. Para aprofundar essa questão, estudou-se como o uso e ocupação do solo estão vinculados à formação do valor da terra urbana em Santos. 


\subsection{Regulação urbanística e mercado imobiliário}

Um dos objetivos fundamentais deste trabalho é investigar em que medida a legislação urbanística, sobretudo a de regulação do uso e ocupação do solo, contribuiu para reforçar o fenômeno da exclusão espacial nos municípios centrais da RMBS. Para tal finalidade desenvolveu-se neste item uma análise da evolução comparativa do valor imobiliário de determinadas áreas da parte insular de Santos.

A cidade de Santos foi utilizada como paradigma, pois, além de sua importância regional, foi nesta cidade - segundo pode-se apurar ao ser analisada a série histórica de plantas genéricas de valores unitários dos demais municípios - que se produziu, ao longo do século $X X$, o maior espectro de valorização imobiliária se comparadas distintas áreas de seu território, e também no qual o processo de aferição do valor da terra se dá, sistematicamente, há mais tempo.

Para esta finalidade foram utilizados dados das plantas genéricas de valores unitários, adotadas pelas municipalidades como base de cálculo do Imposto sobre a Propriedade Predial e Territorial Urbana - IPTU e outros tributos municipais. As plantas apresentam o valor estimado do metro quadrado de terreno, segundo a testada de quadra em que este se localiza, tomando como referência determinadas características da área em que o lote se encontra, como será possível ver mais adiante.
Embora em muitos casos existam distorções no cálculo dos valores $^{109}$, admitidas pelas próprias municipalidades, essas plantas são preciosos registros da evolução da valorização imobiliária nos municípios, publicados anualmente. Tomando como base o ano de 2001, pode-se verificar que os municípios de Santos e Guarujá são os que possuem as áreas mais valorizadas dentre os municípios centrais. Enquanto em Guarujá pudemos encontrar testadas com valores unitários acima de $R \$ 800,00$ (oitocentos reais), em Santos encontramos testadas com cerca de $R \$ 1.500,00$ (um mil e quinhentos reais).

Vale ressaltar, porém, que no caso específico de Santos, a divulgação da planta genérica em 2001, cuja atualização não vinha sendo feita desde 1995, foi acompanhada de grande polêmica, em função da tentativa de corrigir algumas distorções de valores, sobretudo em áreas de baixa renda, segundo afirmou o perito encarregado de sua elaboração, em entrevista para este trabalho. Por tal motivo, a Prefeitura local resolveu, ignorar a planta e reajustar os valores venais por meio da aplicação de um índice único de correção monetária, via decreto executivo.

No entanto, é importante lembrar que, no caso de Santos, as plantas genéricas, como hoje são conhecidas, vêm sendo adotadas desde a década de 1960 e foram atualizadas anualmente, sem interrupção, desde a década de 70 , até 1995. Para que se possa obter as informações de interesse desta pesquisa, vamos utilizar dados comparativos de valores unitários em determinadas testadas, em três anos distintos, que poderiam refletir

\footnotetext{
109 Em SEABRA (1979: 90) pode-se ler que os valores da planta genérica adotada pela Prefeitura, na década de 60, estavam
} subestimados em $30 \%$. 
alguma influência das alterações nas leis de zoneamento, nesse período. As testadas selecionadas referem-se a localizações preferenciais de alta, média e baixa renda, com ou sem a ocorrência de pólos comerciais, de forma a que se possa analisar a evolução do valor imobiliário nas áreas ocupadas pelas populações de diferentes extratos de renda.

A única planta genérica referente à década de 60 é a do ano de 1966 e foi elaborada pelos engenheiros Thomás Amarante e Octávio Cavalleiro, da Comissão de Arbitramento Fiscal da Prefeitura Municipal de Santos, dois anos antes de entrar em vigor o Plano Diretor Físico de 1968. As plantas genéricas da década de 70 referem-se aos anos 1973 e 1978, respectivamente, portanto cinco e dez anos posteriores à sanção do Plano Diretor Físico de 1968, respectivamente. Ambas foram elaboradas pelo escritório do engenheiro Fernando Guilherme Martins, responsável pela produção de todas as plantas genéricas, a partir da década de 70.

$\mathrm{Na}$ introdução deste capítulo procurou-se colher, nas principais obras de referência, indicadores de como se comportava 0 valor imobiliário, em determinadas localizações - nas últimas décadas do século XIX e nas primeiras do século $X X$ - em Santos. No entanto, com a introdução posterior do uso das plantas genéricas de valores, foi possível obter um retrato mais fiel desse processo, no final do Período Desenvolvimentista.

É interessante ressaltar que, metodologicamente, para que se possa aferir se houve ou não valorização de determinada área, as municipalidades e peritos contratados admitem que são levadas em conta eventuais alterações no zoneamento. Nesse aspecto, destaca-se a mensagem do prefeito do
Guarujá, Maurici Mariano, que acompanha o projeto de lei complementar que altera o código tributário, pela introdução de nova planta genérica de valores, com base em 2001, para vigorar em 2002

Enviada à Câmara no final de 2001, a mensagem incluiu as modificações no zoneamento dentre os elementos que podem provocar a alteração do valor imobiliário em determinadas localizações, tais como obras públicas ou privadas e melhoria da infra-estrutura urbana.

Como se viu em ROLNIK (1997: 25), quando a autora se refere ao princípio do século XX: "todas as definições da legislação urbanística, passaram a interferir diretamente no valor da terra, indo além das implicações técnicas e estéticas".

Em NUNES (2001: 179), pôde-se verificar que no início da década de 1950, à época da apresentação do Plano Regulador do Município de Santos elaborado pela equipe de Prestes Maia, "o zoneamento e índices construtivos apenas começavam a se tornar fundamentos do processo imobiliário, haja vista que a verticalização era nascente".

Atualmente, ao que parece, este fator é levado em conta, ainda que indiretamente, pois como será visto a seguir, a metodologia utilizada para a elaboração da planta de valores afere estas alterações no zoneamento e demais índices urbanísticos, ao computar o comportamento do mercado, colhendo amostras de transações de imóveis em determinadas áreas.

Em WELCH (1946: 15), colhemos a informação de que àquela época, nos Estados Unidos da América, cuja escola 
de avaliação imobiliária inspirou a formação de várias gerações de peritos no Brasil, "a classificação de uso da propriedade, tais como residência de família singular, hotel, lote vago, etc (...)" era elemento importante para a descoberta do "preço verdadeiro" de venda dos imóveis, tomados como amostras para a elaboração de uma planta de valores. Mais adiante (1946: 19), WELCH ao discorrer sobre o estudo do preço de uma série de transações imobiliárias também tomadas como amostras, afirmou que "diferentes seções de uma cidade, e mesmo diferentes quarteirões dentro de uma mesma seção, estão sujeitos a diferentes influências econômicas. Uma venda realizada a mais de cinco anos passados, em um distrito de valores estáveis de terrenos, pode ainda representar 0 valor corrente de mercado. Mas em um outro distrito, variações nas posturas de zoneamento, deslocamentos de população, ou outros desenvolvimentos podem ter largamente alterado os valores em um período semelhante" (grifo do autor).

Ainda em WELCH (1946: 26), ao analisar-se o método de avaliação pela renda ${ }^{110}$ da terra, o elemento "classificação de uso do imóvel" figurou dentre os fatores fundamentais que devem ser levados em conta para esta análise. Também na análise do método comparativo, WELCH (1946:

110 Dentre os métodos básicos, elencados por WELCH (1946: 13-58) para avaliação de um imóvel, o "método da renda" é considerado "provavelmente o melhor meio para chegar a um preço merecedor de confiança". Este método consiste em tomar como referência "uma relação exata da renda bruta e das despesas do imóvel em apreço, para toda a vida futura da propriedade". É nesse aspecto que as alterações na legislação urbanística parecem ter influência. Neste capítulo, WELCH compara este método com o "método da venda", o qual considera mais problemático, uma vez que podem faltar exemplos de transações, em determinado tempo e espaço, que possam servir como amostras confiáveis do valor de mercado.
49) relacionou o fator "restrições de zoneamento", dentre os elementos capazes de influenciar os valores dos terrenos ${ }^{111}$. Por último, ao discorrer sobre a "construção do mapa dos quarteirões" - que são partes das plantas de valores - WELCH (1946: 63) novamente incluiu o zoneamento no rol dos fatores a serem considerados para o estabelecimento dos valores unitários.

\footnotetext{
${ }^{111}$ WELCH (1946: 47-51) relaciona o "método comparativo" dentre os métodos derivados, e lhe atribui grande importância, afirmando que este era o método mais aplicado pelos peritos da época. WELCH define este método como sendo o da "comparação da propriedade em estudo com uma ou mais propriedades de valor conhecido" - o que se faz por meio dos métodos básicos. Em seguida, o autor elenca as vantagens desse método, que considera o ideal para a finalidade de tributação da propriedade.
} 


\subsection{Estudo comparativo dos valores unitários em distintas áreas de Santos}

Para que se pudesse proceder ao estudo comparativo dos valores unitários em distintas áreas de Santos, visando com isto evidenciar como o processo de valorização de algumas destas áreas contribuiu para a segregação espacial da baixa renda em outros espaços, inicialmente analisou-se o emprego das plantas genéricas de valores unitários - como são conhecidas hoje - utilizadas pela municipalidade de Santos desde a década de 60 , pelo que se pôde apurar.

No entanto, é importante ressaltar que no início do século XX esta municipalidade já possuía um sistema de cadastro imobiliário que se pode considerar um embrião das plantas genéricas produzidas posteriormente. $\mathrm{Em}$ relatório da Diretoria de Obras e Viação, apresentado à Câmara Municipal, em dezembro de 1919, pode-se ler (1919: 190): "A conservação do Cadastro Imobiliário está em dia. O registro geral de Hipotecas comunica-nos semanalmente as transmissões havidas, e as anotações nas respectivas cadernetas são feitas imediatamente. Pelos preços dessas transmissões e pelas áreas das propriedades vendidas. calculei quanto está valendo presentemente 0 metro quadrado de terreno baldio e de terreno com benfeitorias nos diferentes pontos da cidade" (grifo do autor).

Portanto, mais que organizar um cadastro dos imóveis, este relatório revelou a existência de uma metodologia para cálculo de valores unitários, visando a tributação. Em seguida, foram apresentadas tabelas em que se verifica ter sido a área urbana de então dividida em várias seções para o efeito de cadastramento das transmissões, com o registro de áreas de terreno e áreas de benfeitorias, apontando o valor do conjunto destas por agrupamentos de lotes. Essa metodologia revelava a preocupação, desde então, de que fosse possível obter valores unitários segundo a realidade de mercado de cada área específica da cidade, permitindo uma leitura detalhada da evolução deste mercado, ano a ano.

Por fim, era publicada uma tabela, expressa em Reais ${ }^{112}$ moeda da época - com o "valor do metro quadrado", nos principais logradouros da cidade. Nessa tabela havia uma distinção entre metro quadrado de terreno baldio e terreno construído que, hoje, não se pratica mais, pois, como será visto em seguida, a metodologia atual privilegia a obtenção de amostras relativas a imóveis sem construção.

Contudo, a leitura da referida tabela revelou a proporção entre os valores de terreno, em época que o centro da cidade era relativamente bem mais valorizado, e a ocupação da orla e bairros intermediários apenas se esboçava. Pode-se saber com sua leitura que um terreno na rua XV de Novembro, então logradouro mais valorizado da cidade, possuía um valor de $263 \$ 157$ o $\mathrm{m}^{2}$ do terreno baldio, enquanto que o $\mathrm{m}^{2}$ de terreno construído na mesma via valia $551 \$ 000$.

Em áreas mais afastadas do centro, como a região do Mercado Municipal à Praça Iguatemi Martins, o valor do metro quadrado de terreno construído era de $68 \$ 020$. Já o

\footnotetext{
${ }^{112}$ Até 1942, circulava o Real. Com a continuidade da inflação, o real passou a não ter poder de compra, sendo substituído, na prática, pelos seus múltiplos, ou seja, pelos reais, que o povo, por facilidade de pronúncia, passou a denominar "réis". Mil reais, vulgarmente chamados de "mil-réis", passaram a ser o referencial de unidade monetária, embora, na realidade, fossem múltiplos do real. Fonte: SANDRONI, Paulo (2000).
} 
valor do metro quadrado de terreno baldio, na rua Amador Bueno, importante artéria comercial, era de 59\$000; enquanto o de terreno construído era de $57 \$ 375$. Na rua 7 de Setembro, junto à rua Brás Cubas, área em que a população de alta renda já estava estabelecia, o valor era de $100 \$ 550$, para terrenos construídos.

Na avenida Conselheiro Nébias, o valor variava conforme a área. Junto à rua General Câmara, no centro, o valor era de $137 \$ 700$, para terrenos construídos. Já na área próxima ao Mercado, o valor caía para $96 \$ 000$, para o mesmo tipo de imóvel.

Era este, portanto, o quadro aproximado de valores imobiliários das áreas do Centro e bairros vizinhos. A análise mais imediata que se pode fazer é que, desde as primeiras décadas do século, as áreas de maior potencial comercial eram as mais valorizadas, seguidas de perto pelas localizações onde a burguesia começava a estabelecer suas residências, para escapar justamente dos incômodos gerados pela atividade comercial intensa, além da portuária, é claro. Tais constatações confirmam que a tese de SEABRA, citada no item 5.1., já era uma realidade no mercado imobiliário, trinta anos antes da explosão da construção civil na orla marítima ${ }^{113}$.

\footnotetext{
113 SEABRA afirmou que havia uma verdadeira hierarquia de valor, conforme o uso potencial dos imóveis urbanos, em que o uso comercial era sempre o mais valorizado, seguido pelo residencial e, por último, pelo industrial.
} 


\subsubsection{Análise da evolução do valor imobiliário nas décadas de 60 e 80}

Para a análise da evolução do valor imobiliário nas décadas de 60 e 70 é fundamental compreender o pensamento do perito responsável pela elaboração de todas as plantas genéricas de valor unitário de Santos, desde a década de 70, o engenheiro Fernando Guilherme Martins, membro titular do Instituto Brasileiro de Avaliações e Perícias de Engenharia - IBAPE. Em entrevista realizada com este engenheiro, em dezembro de 2001, foi possível obter informações importantes sobre a metodologia empregada na elaboração destas plantas.

No entanto, complemetarmente, adotou-se como referência -adequada pela época de sua publicação - o caderno Planta Genérica de Valores - Município de Santos e Distrito de Bertioga, que a Prefeitura de Santos publicou, em dezembro de 1979, juntamente com a versão da planta genérica para 0 ano seguinte, no final do que convencionamos chamar Período Desenvolvimentista..

Nesta edição, Fernando Guilherme Martins apresentou com suas próprias palavras "um relatório explicativo das diversas etapas necessárias à execução do serviço" - a elaboração da planta. O autor apresentou os fundamentos teóricos da elaboração da planta e descreve a metodologia, etapas do trabalho e orientou como seria sua aplicação prática.

Fernando Guilherme Martins iniciou o trabalho de elaboração das plantas genéricas em Santos, em 1973, como assessor técnico do Consórcio Argos, Constituído para a elaboração do Cadastro Técnico da Baixada Santista, tendo, entre outras tarefas, a elaboração da planta genérica de Santos. Todos os municípios centrais da Baixada participaram do convênio que resultou na contratação do engenheiro.

MARTINS (1979, item 2: 3), definiu a Planta Genérica de Valores Reais de Terrenos Para as Cidades, como sendo a própria "planta da cidade, contendo assinalados, genericamente, os valores básicos unitários de mercado dos terrenos, quadra por quadra, homogeneizados, inclusive temporalmente, segundo critérios préestabelecidos". É importante que se diga que este conceito de "valor básico de mercado" submetido ao processo de homogeneização guarda grande correspondência com o chamado "método derivado comparativo" descrito em WELCH.

Em MARTINS (1979, item 1: 6), o autor explicou que a divisão territorial do município de Santos, adotada para a elaboração da planta genérica, baseou-se na interseção da planta de divisão em bairros - abairramento - com a de zoneamento, ambas definidas pela Lei $\mathrm{N}^{\circ} 3.529$, de 1968 Plano Diretor Físico do Município de Santos. Às subdivisões que se formam desse cruzamento denominou-se "zonas homogêneas", por ser presumível que "dentro de uma mesma zona homogênea a evolução dos valores se processe de modo uniforme".

Assim, de início pode-se perceber que a questão do zoneamento merece destaque dentre os critérios de avaliação utilizados para a elaboração da planta genérica. Pode-se até mesmo afirmar que o Plano de 1968, se não foi fator determinante no processo de alteração do valor imobiliário no Município, ao menos foi adotado na metodologia de aferição deste processo. 
Como fontes "habituais na pesquisa de valores imobiliários", foram utilizados dados dos "Cartórios dos Registros de Imóveis e o próprio mercado imobiliário, representado, principalmente, pelos escritórios imobiliários" MARTINS (1979, item 1: 8). No caso da planta de 1979, foram obtidas 1.146 amostras de valor, colhidas nas fontes acima mencionadas.

Em seguida, lançadas na planta, as amostras foram submetidas aos "Fatores de Atualização Médio", por meio da operação de divisão dos valores unitários básicos, pelos valores unitários correspondentes, nos mesmos locais, no ano anterior. Por último, após efetuar-se correções pontuais, obteve-se um "Fator de Atualização", o qual foi utilizado numa operação de multiplicação de todos os demais valores unitários, dentro da mesma zona homogênea. Tal fato demonstrou a importância do zoneamento no processo de aferição dos valores imobiliários.

Segundo se lê mais adiante em MARTINS (1979, item 2: 5), metodologicamente foram avaliadas as influências, sobre os valores unitários de determinada área, de determinadas referencias, as quais MARTINS denomina "Pólos de Valorização". Estes pólos que podem ser pontuais ou lineares, como explicou MARTINS, podem ser áreas comerciais, a orla marítima - no caso das cidades balneárias - e outros. Este fator foi determinante na escolha de algumas testadas de quadra, aplicadas na Tabela 17, com a qual foi possível avaliar a evolução de valores básicos em determinadas áreas de Santos, conforme será apresentado em seguida.
O autor apresentou, ainda, importante informação, no tocante ao objetivo do presente trabalho, em relação à questão do uso do solo (1979, item 2: 6): "O meio urbano é um organismo vivo, sujeito a fenômenos previsíveis, normais, e a outros inesperados, imprevistos.

Por esse motivo, a planta genérica, para refletir toda a variação econômica do meio, deverá utilizar um método de trabalho que a torne sensível ao crescimento natural, aos melhoramentos realizados, à legislação reguladora do uso da terra e às tendências de mercado" (grifo do autor).

É interessante observar, como o engenheiro MARTINS atribuiu uma importância equivalente entre valor de mercado e regulação urbanística, sem esclarecer, contudo, em que medida ambas as coisas estão imbricadas.

Com relação ao mercado imobiliário, vale ressaltar a observação de MARTINS (1979, item 2: 12) de que, a despeito das análises sistemáticas das transações em cartórios, existe uma enorme variação dos valores. Neste aspecto MARTINS acrescentou que esta variação decorria do "desconhecimento do valor da coisa, pelas partes interessadas, em decorrência de uma fonte informadora segura".

Em seguida MARTINS elaborou reflexão acerca do conceito de valor, comparando o "valor real de mercado" ao "valor de venda", e defendendo com convicção a utilização da planta genérica, como fonte de informação segura para a realização de transações imobiliárias, procedimento questionado por SEABRA (1979), no tocante à metodologia utilizada na década de 60 . 
Adiante, MARTINS advoga que o valor básico unitário relativo à face de cada quadra deve corresponder sempre ao lote vago, para que não haja distorções. Quando isto não fosse possível, deveria ser eliminada do cálculo a influência do valor da benfeitoria.

Com essas informações que parecem fundamentais, será apresentada, em seguida, a Tabela de Evolução do Valor Unitário, segundo a localização da testada, nas Plantas Genéricas de Valor dos anos de 1966, 1973 e 1978. Ressalta-se que, embora a metodologia aplicada em 1966, seja distinta da aplicada por MARTINS nas demais plantas, na ausência de outros elementos que permitam realizar esta comparação de forma mais expedita, considerou-se oportuna a utilização dos dados daquele ano, para o aperfeiçoamento da comparação que será apresentada baseando-se na Tabela 17. Afinal, mais do que os valores absolutos interessa a comparação entre as distintas áreas da cidade, o que não fica prejudicado, com a utilização desses dados.

A atualização monetária dos dados em moedas da época foi realizada por este autor tomando como base a Tabela de Atualização de Débitos Judiciais do Tribunal de Justiça de São Paulo, que além de ser utilizada pelo Judiciário, é amplamente empregada por peritos avaliadores. Esta atualização é relativa ao mês de fevereiro de 2001.

Observa-se ainda que os valores são correspondentes ao mês de dezembro de cada ano - com a exceção dos dados referentes à Zona Noroeste para o exercício de 1966, que são referentes a fevereiro de 1967.
Nas plantas genéricas correspondentes aos anos de 1973 e 1978, elaboradas pelo engenheiro Fernando Guilherme Martins, as amostras utilizadas na pesquisa corresponderam a 1\% do universo dos imóveis cadastrados na Secretaria Municipal de Finanças da Prefeitura de Santos, nos respectivos exercícios, extraídas apenas de transações imobiliárias recentes para a época. 
Tabela 17

Evolução do valor unitário de terreno, segundo a localização da testada, nas Plantas Genéricas de Valor de Santos, nos anos de 1966, 1973 e 1978.

\begin{tabular}{|c|c|c|c|c|c|c|c|c|c|c|}
\hline & Testada & $\begin{array}{l}\text { Trecho } \\
\text { referência }\end{array}$ & $\begin{array}{l}\text { Setor e } \\
\text { Quadra } \\
\text { fiscais }\end{array}$ & $\begin{array}{c}\text { Valor em } \\
1966 \\
\text { Cruzeiros }\end{array}$ & \begin{tabular}{|c|} 
Valor em \\
1966 \\
Corrigido \\
em Reais \\
\end{tabular} & \multirow[t]{2}{*}{$\begin{array}{c}\text { Valor em } \\
1973\end{array}$} & \multirow[t]{2}{*}{$\begin{array}{c}\text { Valor em } \\
1973 \\
\text { Corrigido } \\
\text { em Reais } \\
7\end{array}$} & \multirow[t]{2}{*}{$\begin{array}{l}\text { Valor em } \\
1978\end{array}$} & \multirow{2}{*}{ 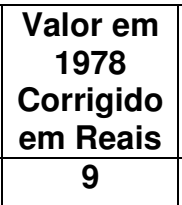 } & \multirow[t]{2}{*}{\begin{tabular}{|c|} 
Variação \\
$\%$ entre \\
$1966-1978$ \\
10
\end{tabular}} \\
\hline & 1 & 2 & 3 & 4 & 5 & & & & & \\
\hline \multicolumn{11}{|c|}{ 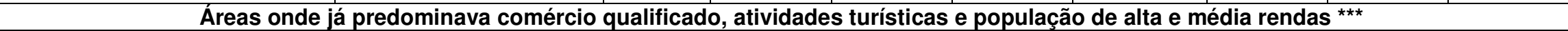 } \\
\hline 1 & Av. Vicente de Carvalho & Av. A. Costa & $65 / 38$ & 375.000 & 418,68 & $1.132,76$ & 394,97 & 12680 & 1008,77 & 240,94 \\
\hline 2 & R. Valdomiro Silveira & R. Minas Gerais & $66 / 27$ & 62.500 & 69,78 & 215,46 & 69,03 & 7220 & 574,40 & 823,15 \\
\hline 3 & Av. dos Bancários & R. Rep. Do Perú & $89 / 29$ & 25.000 & 27,91 & 85,50 & 27,39 & 4920 & 391,42 & 1402,42 \\
\hline 4 & Av. Joaquim Montenegro & Av. Epitácio Pessoa & $88 / 5$ & 50.000 & 55,82 & 344,28 & 110,30 & 4920 & 391,42 & 701,21 \\
\hline 5 & Av. Bartolomeu de Gusmão & Av. Cel. J. Montenegro & $78 / 18$ & 175.000 & 196,38 & 916,42 & 293,60 & 7380 & 587,12 & 298,97 \\
\hline 6 & Av. Ana Costa & Pátio da Sorocabana & $55 / 35$ & 62.500 & 69,78 & 136,80 & 43,83 & 4620 & 367,55 & 526,73 \\
\hline 7 & Av. Mal. Deodoro & Av. Bern. de Campos & $65 / 9$ & 75.000 & 83,73 & 215,46 & 69,03 & 4000 & 318,22 & 380,06 \\
\hline 8 & Av. Presidente Wilson & Av. Bern. de Campos & $65 / 29$ & 275.000 & 307,03 & $1.033,98$ & 331,28 & 8720 & 693,73 & 225,95 \\
\hline 9 & Av. Epitácio Pessoa & R. Januário dos Santos & $78 / 59$ & 100.000 & 111,65 & 344,28 & 110,30 & 4920 & 391,42 & 350,57 \\
\hline 10 & Av. Washington Luiz & R. Azevedo Sodré & $66 / 14$ & 100.000 & 111,65 & 344,28 & 110,30 & 8190 & 651,56 & 583,58 \\
\hline 11 & Av. Vicente de Carvalho & R. da Paz & $66 / 48$ & 300.000 & 334,95 & $1.033,98$ & 331,28 & 12320 & 980,13 & 292,62 \\
\hline 12 & R. Piauí & Av. Francisco Glicério & $64 / 23$ & 50.000 & 55,82 & 188,10 & 60,26 & 3690 & 293,56 & 525,91 \\
\hline 13 & R. Carlos Gomes & Av. Bern. de Campos & $55 / 32$ & 40.000 & 44,66 & 136,80 & 43,83 & 2360 & 187,75 & 420,40 \\
\hline 14 & R. Maria dos Reis & Parque da Montanha & $43 / 18$ & * & * & 10,26 & 3,28 & 180 & 14,32 & * \\
\hline \multicolumn{11}{|c|}{ Áreas onde já predominava população de média renda e comércio de bairro } \\
\hline 15 & Av. Pedro Lessa & R. Guaibê & $68 / 6$ & 30.000 & 33,49 & 101,04 & 32,50 & 2580 & 205,25 & 612,88 \\
\hline 16 & R. Carvalho de Mendonça & Av. Bern. de Campos & $55 / 3$ & 50.000 & 55,82 & 174,42 & 55,88 & 2540 & 202,07 & 362,01 \\
\hline 17 & Av. Washington Luiz & R. Carv. de Mendonça & $46 / 49$ & 45.000 & 50,24 & 153,90 & 49,38 & 3100 & 246,62 & 490,89 \\
\hline 18 & Av. Ana Costa & R. Rangel Pestana & $35 / 12$ & 57.500 & 64,19 & 172,14 & 55,15 & 3550 & 282,42 & 439,98 \\
\hline 19 & R. Mons. Paula Rodrigues & R. São Paulo & $45 / 45$ & 35.000 & 39,07 & 111,72 & 35,79 & 2190 & 174,23 & 445,94 \\
\hline 20 & Av. Rodrigues Alves & R. Osvaldo Cruz & $56 / 17$ & 42.500 & 47,45 & 145,92 & 46,75 & 2760 & 219,57 & 462,75 \\
\hline 21 & R. Comendador Martins & R. Cunha Moreira & $56 / 5$ & 42.500 & 47,45 & 136,80 & 43,83 & 2440 & 194,12 & 409,10 \\
\hline 22 & Av. Afonso Pena & R. Lacerda Franco & $68 / 72$ & 30.000 & 33,49 & 101,46 & 32,50 & 2280 & 181,39 & 541,62 \\
\hline \multicolumn{11}{|c|}{ Centro e áreas periféricas onde predominava atividade comercial } \\
\hline 23 & Pça. Da República & Alfândega & $26 / 11$ & 112.500 & 125,60 & 387,60 & 124,18 & 4680 & 372,32 & 296,44 \\
\hline 24 & Av. Senador Feijó & R. Rangel Pestana & $36 / 32$ & 62.500 & 69,78 & 215,46 & 69,03 & 3630 & 288,79 & 413,86 \\
\hline 25 & R. Itororó & Av. São Francisco & $36 / 1$ & 125.000 & 139,56 & 430,92 & 136,06 & 6100 & 485,29 & 347,73 \\
\hline
\end{tabular}


Legislação urbanística e segregação espacial nos municípios centrais da Região Metropolitana da Baixada Santista

\begin{tabular}{|c|c|c|c|c|c|c|c|c|c|c|}
\hline 26 & Av. João Pessoa & Av. Senador Feijó & $26 / 16$ & 137.500 & 153,51 & 688,56 & 220,61 & 7950 & 632,47 & 412,01 \\
\hline 27 & R. São Bento & Av. São Leopoldo & $25 / 11$ & 45.000 & 50,24 & 136,80 & 43,83 & 3030 & 241,05 & 479,81 \\
\hline 28 & Pça. Mauá & R. General Câmara & $25 / 23$ & 500.000 & 558,25 & $1.123,68$ & 360,62 & 17420 & 1385,87 & 248,25 \\
\hline 29 & R. General Câmara & R. Dr. Cochrane & $26 / 20$ & 40.000 & 44,66 & 136,80 & 43,83 & 2240 & 178,21 & 399,03 \\
\hline \multicolumn{11}{|c|}{ Áreas onde já predominava população de baixa renda (Mercado, Zona Noroeste e Morros) } \\
\hline 30 & R, Manoel Tourinho & R. Da. Luiza Macuco & $47 / 1$ & 30.000 & 33,49 & 101,46 & 32,50 & 2090 & 166,27 & 496,48 \\
\hline 31 & Pça. Iguatemi Martins & Mercado & $36 / 22$ & 45.000 & 50,24 & 155,04 & 49,67 & 2340 & 186,16 & 370,54 \\
\hline 32 & Av. Campos Sales & Av. Cons. Nébias & $36 / 44$ & 47.500 & 53,03 & 144,78 & 46,38 & 2610 & 207,64 & 391,55 \\
\hline 33 & Av. Jovino de Melo** & R. Com. Bulcão Viana & $31 / 32$ & 7.500 & 7,99 & 25,08 & 8,03 & 620 & 49,32 & 617,33 \\
\hline 34 & Av. Brig. Faria Lima** & R. V. Álvaro Guimarães & $40 / 1$ & 4.000 & 4,26 & 13,60 & 4,35 & 420 & 33,41 & 784,36 \\
\hline 35 & Pça. Firmino Barbosa** & R. Dr. Nilo Rodrigues & $40 / 61$ & 6.000 & 6,39 & 20,52 & 6,57 & 430 & 34,21 & 535,35 \\
\hline 36 & Av. Hugo Maia** & R. V. Álvaro Guimarães & $40 / 37$ & 6.000 & 6,39 & 20,52 & 6,57 & 430 & 34,21 & 535,35 \\
\hline 37 & R. Américo Moretti ${ }^{\star \star}$ & Av. Jovino de Melo & $41 / 38$ & 7.000 & 7,45 & 23,94 & 7,67 & 630 & 50,12 & 672,76 \\
\hline 38 & R. Alderico M. Soares ${ }^{\star *}$ & R. Com. Luiz Caiaffa & $30 / 16$ & 5.500 & 5,85 & 18,24 & 5,84 & 560 & 44,55 & 761,56 \\
\hline 39 & R. Prof. Arnaldo A. Ferreira ${ }^{\star *}$ & R. Prof. F. De Domênico & $41 / 75$ & 2.500 & 2,66 & 8,20 & 2,62 & 530 & 42,16 & 1585,14 \\
\hline 40 & R. Mário Graccho** & R. Prof. Francisco Meira & $20 / 13$ & 6.000 & 6,39 & 20,52 & 6,57 & 330 & 26,25 & 410,85 \\
\hline 41 & Av. Santista & Morro da Nova Cintra & $43 / 19$ & * & * & 10,26 & 3,28 & 200 & 15,91 & * \\
\hline 42 & Lgo. São Bento & Morro São Bento & $35 / 41$ & * & * & 10,26 & 3,28 & 100 & 7,96 & * \\
\hline
\end{tabular}

* Dados não disponíveis na Planta Genérica de 1966.

** Logradouros da Zona Noroeste, cujos valores constavam em Planta Genérica à parte, expressos em Cruzeiros Novos. Para os efeitos deste trabalho a correção monetária foi feita por meio da aplicação do coeficiente de fevereiro de 1974, pois este foi o primeiro mês de NCr\$ (cruzeiros novos), o que indica que os dados da Zona Noroeste eram de 1974.

*** Exceção feita ao Parque da Montanha, cuja área era praticamente desocupada e ao bairro da Ponta da Praia, cuja ocupação mais intensiva deu-se a partir da década de 1970.

Observações:

1. Os valores, das colunas 5,7 e 9, estão corrigidos em reais referentes ao mês de fevereiro de 2001.

2. O valor unitário das testadas é sempre referente ao mês de dezembro de cada ano, com exceção dos dados relativos à Zona Noroeste, no ano de 1966, que se referem a fevereiro de 1967.

3. As plantas passaram a vigorar nos respectivos exercícios seguintes. 


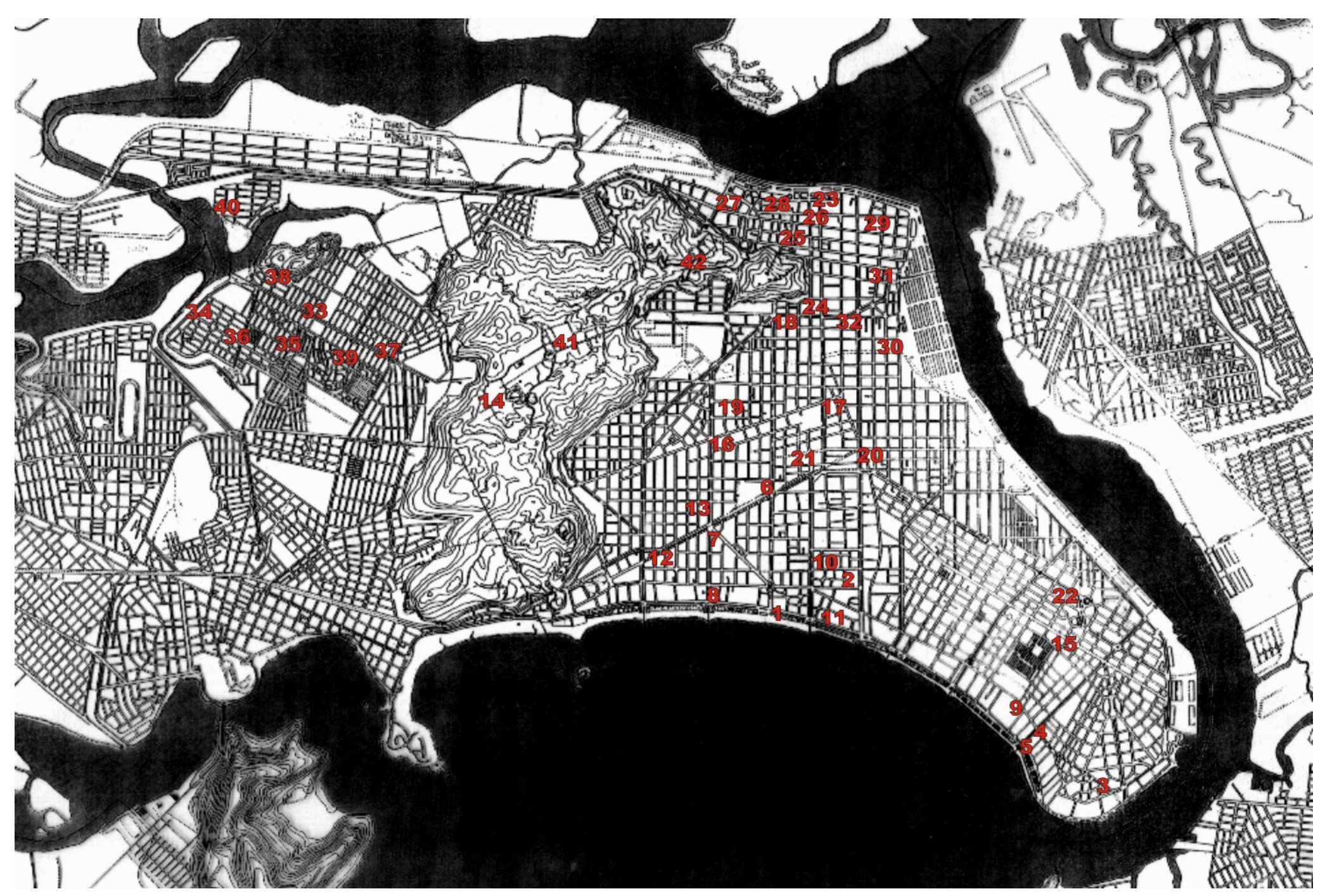

Figura 45 - Planta da área insular do Município de Santos com a localização das testadas relacionadas na Tabela 17. 
Procurou-se analisar os dados da Tabela 17 sob diferentes enfoques. Iniciando-se pela questão da valorização da orla, ficou evidente que no período escolhido os valores unitários das testadas situadas nas avenidas da praia - Presidente Wilson, Vicente de Carvalho e Bartolomeu de Gusmão tiveram evolução bastante inferior à média da variação geral - coluna 10, Variação \% entre 1966 e 1978.

Essas localizações, em pelo menos dois casos - ambas na avenida Vicente de Carvalho, nos bairros do Gonzaga e Boqueirão - sofreram decréscimo de valor, entre 1966 e 1973, o que pode ser observado comparando-se as colunas de valores em reais de ambos os anos - colunas 5 e 7 . Talvez este fenômeno possa ser explicado pela saturação do mercado nestas áreas, em função do diferencial entre valor dos terrenos e valor final das unidades ter diminuído, conforme apontou SEABRA (1979), relativamente ao período que se analisou.

Merece especial menção a valorização dos imóveis no bairro da Ponta da Praia, entre 1966 e 1978 - coluna 10 em que localizações como as das avenidas Coronel Joaquim Montenegro - Canal 6 - e dos Bancários, além da avenida Pedro Lessa, tiveram uma taxa bruta de acréscimo de $1.402,42 \%, 701,21 \%$ e $612,88 \%$, respectivamente ${ }^{114}$.

Fenômeno semelhante ocorreu, no mesmo período, com as testadas da Zona Noroeste, com variações sempre superiores a $500 \%$, com exceção da testada da rua Mário Graccho, no bairro São Manoel. Em testadas como a da rua Professor Arnaldo A. Ferreira, no bairro areia Branca, a valorização chegou a 1.585,14\%.

${ }^{114}$ Esta taxa mede a variação percentual dos valores unitários de cada testada entre os anos de 1966 e 1978.

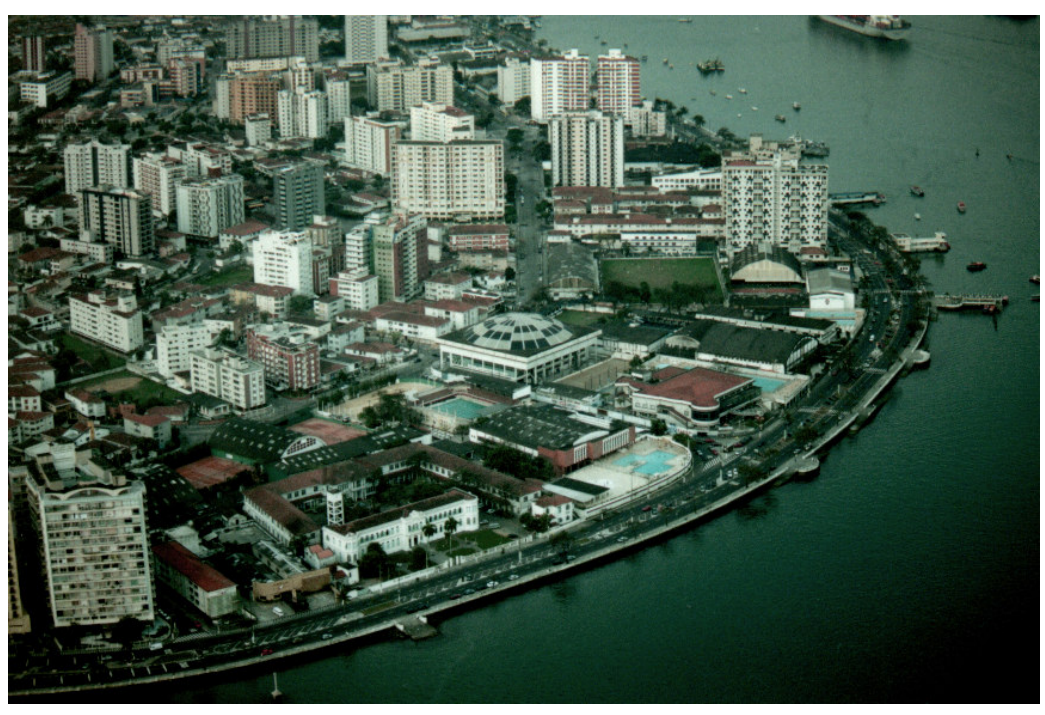

Figura 46 - Vista aérea do bairro Ponta da Praia - Santos. Foto do autor, 2000.

Guardadas as devidas proporções, pois os valores unitários diferem substancialmente - por tratar-se a Ponta da Praia (ver Figura 46) de um bairro de média e alta renda e a Zona Noroeste de uma região de média e baixa renda - em ambos os casos, essas variações podem ser explicadas pelo fato de serem áreas com ocupação rarefeita na década de 1969, e que sofreram um processo de rápido adensamento até o final da década de 1970.

Variações menores sofreram os valores correspondentes às testadas dos logradouros do Centro e áreas periféricas. Destaca-se, nesse caso, a Praça Mauá, coração cívico da cidade, onde se localiza o Paço Municipal, com variação de apenas $248,25 \%$, bastante inferior à média. Na verdade, esta variação só é inferior à da testada da avenida Vicente 
de Carvalho, junto à avenida Ana Costa, uma das testadas mais valorizadas da cidade. Pode-se afirmar que o Centro e sua periferia imediata tiveram evolução inferior a de todas as demais áreas analisadas, com exceção da orla, expurgada a valorização das testadas da Ponta da Praia.

Neste aspecto parece não ter significado incremento na valorização, o dispositivo no Plano Diretor de 1968 que vedou a construção de moradias no Centro. Na verdade, este dispositivo só teve efeito no tocante a possíveis empreendimentos para a população de baixa renda, pois há muito o mercado não tinha interesse em produzir moradias no Centro, seja para a classe média, seja para a classe de mais alta renda.

Da região intermediária da Zona Leste da cidade, o segundo grupamento de testadas analisadas, pode-se dizer que obteve valorizações próximas da média, o que era de se esperar, pois no período analisado era uma região em que havia oferta de infra-estrutura e lotes em quantidade razoável, onde não houve pressão tão grande do mercado imobiliário, como na orla e na Zona Noroeste. Neste aspecto pode-se inferir que, os mercados imobiliários de alta, média e baixa rendas, desenvolvendo-se em diferentes áreas, podem estar aquecidos, provocando altas percentualmente equivalentes.

Assim, há que se fazer uma distinção, entre esses fenômenos, o que é fundamental para o objetivo deste trabalho. A área da Ponta da Praia e algumas áreas da orla, como a região da Vila Rica, no bairro do Boqueirão, em que figura a testada da rua Valdomiro Silveira, com seus expressivos $823,15 \%$ de valorização, já eram localizações preferenciais da alta burguesia nesta época. Ao passo que a rua Professor Arnaldo A. Ferreira, no Areia Branca, era uma área em que a Prefeitura interveio, por meio de um processo de urbanização e regularização fundiária, em um dos primeiros assentamentos irregulares da Zona Noroeste.

Também, é importante verificar em termos relativos, como evoluíram os valores das áreas de melhor e pior localização, em função da disponibilidade de infra-estrutura e oferta de serviços. Em 1966, o maior e o menor valores, testadas da Praça Mauá e rua Professor Arnaldo A. Ferreira - não computadas as áreas dos morros, que não eram estimadas - guardavam entre si uma diferença de 20.986,84\%. Em 1973 a diferença entre o maior e o menor valores, testadas da avenida Vicente de Carvalho, junto à avenida Ana Costa e rua Professor Arnaldo A. Ferreira, era de 15.075,19\%. Em 1978, a diferença entre o maior e o menor valores, testadas da Praça Mauá e do Largo do São Bento, era de $17.410,55 \%$

Segundo informação do próprio engenheiro Fernando Guilherme Martins, hoje esta diferença caiu bastante, em função da escassez de terrenos disponíveis na Zona Noroeste e nos morros, além da melhoria no padrão das construções nestas áreas, que pode indicar uma elevação no nível de renda de suas populações. No entanto, já no período posterior à entrada em vigor do Plano Diretor de 1968 houve uma queda de cerca de $25 \%$ na diferença, entre o maior e menor valores, em 1973; para depois ocorrer uma nova ampliação, para um diferencial próximo a $12,5 \%$, em 1978.

Tal fenômeno pode indicar que o conjunto dos fatores formadores da valorização dos imóveis junto à orla permaneceram atuantes, como de fato estiveram, durante a 
maior parte do século XX, na cidade de Santos. Talvez os efeitos das alterações no zoneamento e nos índices, provocados pelo Plano Diretor de 1968, tenham contribuído para reforçar ou até aprofundar este fenômeno. No entanto, não parecem ter sido determinantes.

Para possibilitar uma melhor visualização da diferença de valores unitários entre as distintas parcelas da área insular de Santos, apresenta-se nas figuras 47, 48 e 49, a cópia de três plantas desta área. Estas plantas são relativas aos anos de 1974, 1984 e 1992, e foram encontradas nos arquivos do extinto Departamento de Planejamento Urbano, da Secretaria de Meio Ambiente da Prefeitura Municipal de Santos. Embora não se tenha identificado sua origem precisa, sabe-se que foram elaboradas por estudantes de pós-graduação que trabalhavam junto àquele departamento, baseadas em dados da Secretaria Municipal de Finanças.

É interessante reproduzi-las no presente trabalho, pois representam graficamente a evolução do valor imobiliário por quadras, portanto com metodologia distinta da utilizada na elaboração das plantas genéricas, em período que se sobrepõe parcialmente ao analisado anteriormente, estendendo-se de 1974 a 1992.

Nas três plantas tomou-se como base o valor da quadra localizada na confluência das avenidas Vicente de Carvalho e Ana Costa, lado leste, onde se situa a testada $\mathrm{N}^{0} 1$, a de maior valor no período analisado na Tabela 17. Conferindose a esta quadra o valor 100, pode-se observar uma gradação cromática, dos valores, entre 0 e 100 e entre 100 e 150.
A leitura mais evidente destes mapas é a permanência, inabalável da valorização dos imóveis na orla, com variações para maior no Gonzaga, sobretudo ao longo do eixo da avenida Ana Costa, com valorização crescente no período, atingindo até os eixos das avenidas General Francisco Glicério e Afonso Pena, junto à linha férrea da CPTM. Da mesma forma, observa-se a crescente valorização da Vila Rica e Ponta da Praia.

No mesmo período observa-se o processo de acelerada desvalorização do Centro. Segundo a metodologia utilizada, pode-se observar, ainda, que o diferencial de valores entre a Zona Noroeste, morros e a área intermediária entre o centro e a orla, não é de grandes dimensões, daí essas áreas estarem representadas sem cor, nas três plantas.

Também, no que concerne ao valor da orla marítima, podese concluir que a valorização destes espaços atinge um ponto de saturação, e as áreas imediatamente posteriores passam a valorizar-se relativamente mais deste ponto em diante, no sentido do interior do território, por meio dos eixos viários. Este raciocínio pode ser estendido analogamente aos demais municípios litorâneos.

Essa tendência, com o passar dos anos, pode contribuir para o agravamento da exclusão espacial, pois os terrenos mais distantes da orla passam a ficar mais disputados e mais valorizados.

Nestas áreas, como em todas as demais analisadas, parece não haver um nexo direto entre as alterações introduzidas pelo Plano de 1968, nem pelas suas modificações posteriores. Ao contrário, estas modificações vieram a reboque da intenção de obter um máximo lucro nas 
transações imobiliárias, bem como de consolidar uma área de excelência, a Zona Leste, fenômeno que teve origem no final do Período do Café, com a implementação do Plano de Saturnino de Brito.

Com efeito, a partir da comparação dos dados da Tabela 17, bem como das figuras 47, 48 e 49, não foi possível evidenciar qualquer reflexo direto, em termos de indução à valorização imobiliária, advindo da aplicação do Plano Diretor de 1968 em qualquer área da cidade. Tal constatação parece confirmar as teses expostas, sobretudo por BONDUKI (1998), CASTELLS (1978), LOJKINE (1981), MARICATO (1996), ROLNIK (1997), SEABRA (1979) e VILLAÇA (1998).

Especialmente em SEABRA é possível encontrar elementos capazes de lançar luz a esta questão. Esta autora, ao definir o conceito de "uso possível", afirmando que é em função "de um uso que se vislumbra como possível que se definem as modalidades de uso do solo", deixou claro que o interesse do mercado em determinadas áreas é que acaba por moldar seus usos.

Assim, o interesse do mercado, que resulta na elevação do valor imobiliário - e isto ocorre até em áreas onde predomina população de baixa renda - acaba por provocar a alteração da legislação urbanística, que termina apenas por legitimar uma situação que já está consolidada. Ou seja, a regulação do solo urbano funciona sistematicamente como elemento de reforço aos interesses do mercado. Neste aspecto, como foi possível ver, o caso de Santos é paradigmático. 




Figura 47 - Variação dos valores imobiliários na área insular da cidade de Santos, em 1974. Fonte Departamento de Planejamento Urbano da Prefeitura Municipal de Santos. 


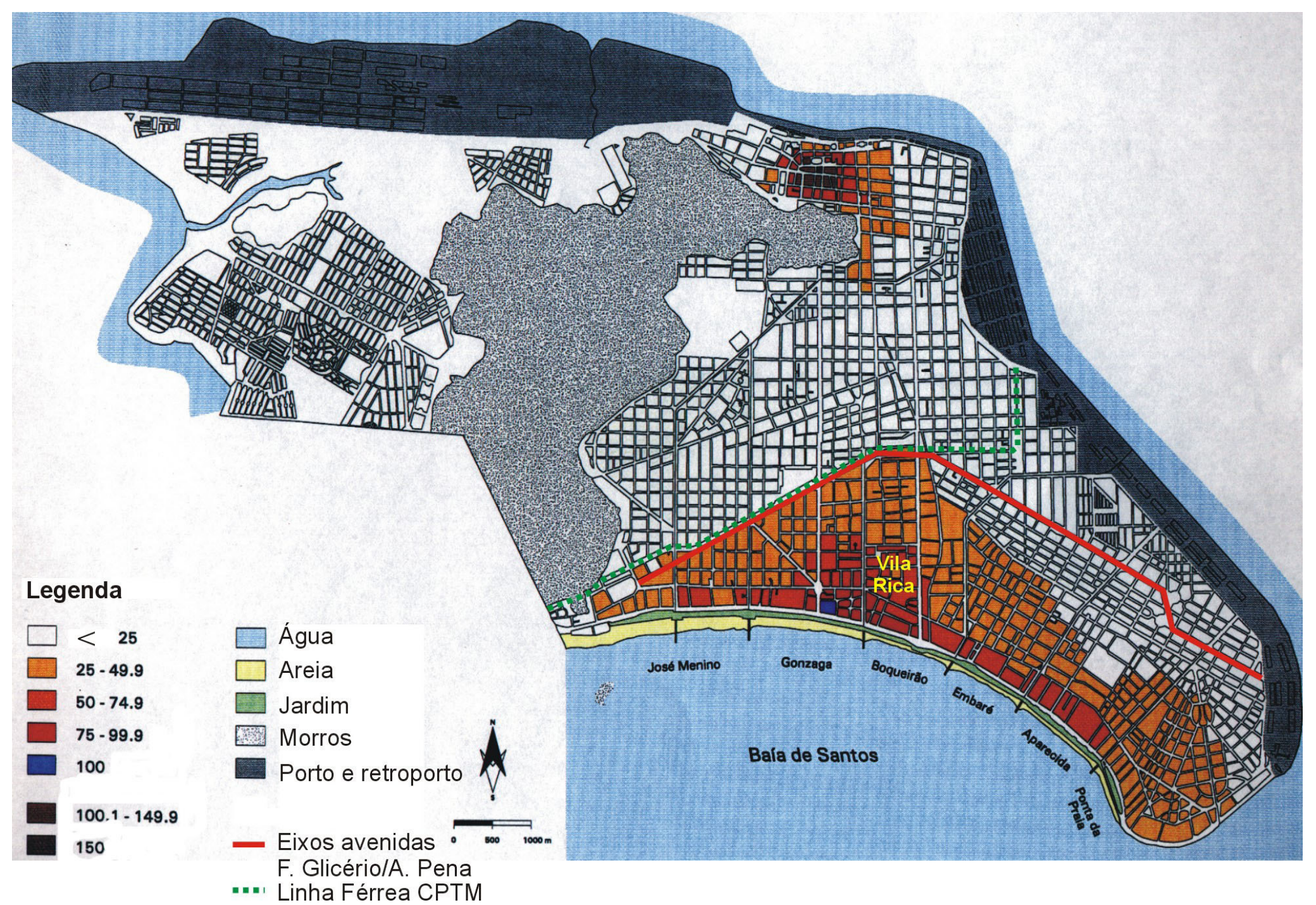

Figura 48 - Variação dos valores imobiliários na área insular da cidade de Santos, em 1984. Fonte: Departamento de Planejamento Urbano da Prefeitura Municipal de Santos. 




Figura 49 - Variação dos valores imobiliários na área insular da cidade de Santos, em 1992. Fonte: Departamento de Planejamento Urbano da Prefeitura Municipal de Santos. 
Legislação urbanística e segregação espacial nos municípios centrais da Região Metropolitana da Baixada Santista

6. Conclusão 
Legislação urbanística e segregação espacial nos municípios centrais da Região Metropolitana da Baixada Santista 
"Noventa por cento dos habitantes quase nada possuem, senão sua capacidade de trabalhar e gerar mais riquezas para os ricos. A desigualdade foi se tornando tão escandalosa que alguns intelectuais sentiram-se na obrigação moral de denunciá-la. Mas logo os ideólogos do regime vieram a público reafirmar a tese de que a escolha não era entre a igualdade e a desigualdade, mas entre $o$ desenvolvimento e a estagnação. 'Está demonstrado pela história', escreveu $R$. Field, 'que a tentativa de dividir igualmente entre todos a riqueza da sociedade conduz à inibição da capacidade produtiva. Engessa-se a economia e tolhe-se a iniciativa dos mais capazes. O resultado é a redução da atividade econômica, o desemprego e o agravamento da pobreza. A desigualdade não é um mal, mas um bem' ".

GULLAR (1997: 40-41).

$\mathrm{Na}$ literatura de referência utilizada nesta pesquisa, mencionada nos respectivos capítulos, pode-se encontrar variadas interpretações do fenômeno da segregação espacial. Em muitas delas são estabelecidos vínculos entre o encarecimento do solo e a aplicação de novas regulações urbanísticas.

Ao procurar explicar o fenômeno da segregação espacial, alguns autores acabam por apresentar como indutores deste processo causas diversas. $O$ incremento da taxa de urbanização das cidades brasileiras, ocorrido a partir do final do século XIX e acelerado na segunda metade do século XX, é uns dos exemplos entre outros abaixo sintetizados.

MEIRELLES (2000) estabeleceu como sendo a urbanização em si a causa da segregação social, propondo um vínculo entre esta e o encarecimento do solo, apontando a regulação urbanística como instrumento capaz de permitir o enfrentamento do problema.

SIRKIS (2002), diferentemente de MEIRELLES, viu na prolixidade e burocratização da regulação urbanística a causa da segregação e vislumbrou em seu aperfeiçoamento o instrumento de transformação dessa realidade, por meio da definição de uma regulação urbanística específica para os espaços ocupados pela população de baixa renda, mais próxima da "tolerância" mencionada em SIMONSEN (1941). Esta tolerância significava a possibilidade de flexibilização da regulação urbanística visando tornar os empreendimentos habitacionais mais acessíveis à classe operária daquele período.

A reprodução de interpretações como essas e outras tantas formaram, ao longo de décadas, uma sólida concepção ideológica, que VILLAÇA (1998) abordou em profundidade.

No entanto, SIMONSEN (1941) encontrou no regime de baixa remuneração da mão-de-obra, que vigora no Brasil desde a abolição da escravatura, o verdadeiro responsável pelas más condições de moradia dos operários, a despeito de iniciativas para flexibilização da regulação urbanística, que existiram em alguns municípios e também na RMBS, como ocorreu em Santos, São Vicente e Guarujá, por exemplo. 
Em CYTED (2001), encontra-se uma interpretação para o fenômeno da segregação urbana mais próxima da enunciada por SIMONSEN (1941). Nesta obra considera-se - padrão brasileiro de baixa remuneração a causa da segregação nas metrópoles, em oposição às analises que, recorrentemente, a atribue ao trinômio urbanização, regulamentação urbanística e valorização do solo.

Nesta pesquisa procurou-se apontar para os municípios centrais da RMBS, e em especial no caso de Santos, o que há de peculiar no domínio da produção e reprodução de idéias e concepções distorcidas sobre a questão da segregação espacial. Além disso, na medida em que se aprofundou o estudo da legislação urbanística, pôde-se perceber que a "tolerância" de SIMONSEN (1941) esteve presente na prática cotidiana desses municípios, na maior parte do período em tela.

Observou-se, por exemplo, que já no século XIX, os padrões oficiais foram desrespeitados para a construção de cortiços. No caso da Zona Noroeste de Santos, para possibilitar a implantação de padrões urbanísticos mais acessíveis à população de média e baixa rendas, tolerou-se a subdivisão de lotes, em desrespeito à exigência de dimensão mínima de $300 \mathrm{~m}^{2}$ estabelecida pelo plano Diretor Físico de 1968.

Observou-se, ainda, que nos casos de Santos e Guarujá, a pressão dos interesses do setor da promoção imobiliária provocou a alteração de Planos e Códigos, permitindo o aumento da exploração intensiva do espaço mais valorizado - a orla marítima.

Em Santos, a Lei $N^{\circ} 174$, de 21 de junho de 1986, alterou índices urbanísticos e o zoneamento vigente, respondendo às pressões de empresários do segmento imobiliário, no sentido de permitir melhor aproveitamento dos terrenos na orla e áreas contíguas.

Não raro imperou o que BONDUKI (1998: 286) denominou "conluio branco entre loteadores, compradores, Executivo, Legislativo e Judiciário" para não se criar obstáculos à ocupação irregular dos territórios ambientalmente frágeis, pela população de baixa renda.

A Lei № 1.266, de 24 de dezembro de 1975, que instituiu o Plano Diretor Físico do Município do Guarujá, foi alterada no ano seguinte, pela Lei № 1.313, de 8 de novembro, servindo aos interesses do setor imobiliário, que visava a ampliação do adensamento nas áreas mais valorizadas, junto à orla da Praia de Pitangueiras.

Em São Vicente, a Lei № 2.061, de 26 de dezembro de 1985 , alterou dispositivos da Lei № 2.025 do mesmo ano, que definia e delimitava as Zonas Urbanas, as Especiais e as de Preservação Ambiental e Rural da área de Samaritá, cedendo à pressão dos empresários da área de promoção imobiliária que intensificavam seus investimentos na área continental daquele município.

Todas essas alterações reafirmam o conceito de "uso possível" do solo urbano, enunciado por SEABRA (1979). Ou seja, no tocante ao uso e ocupação do solo, há determinados interesses submetidos somente aos desígnios do mercado, que parecem sobrepor-se a qualquer tentativa de controle por meio da legislação urbanística. 
Assim, a tolerância a formas de urbanização consideradas inadequadas e principalmente à ocupação desordenada dos espaços ambientalmente frágeis, por um lado, e a alteração sistemática da regulação, visando a realização de grandes lucros imobiliários, por outro, foram e são faces da mesma moeda. Ambas constituindo-se em comprovação irrefutável da fragilidade das teorias que apontam a regulação urbanística como causa da segregação espacial, seja por sua ausência ou deficiência, seja por provocar valorização exacerbada de determinadas áreas da cidade.

Na verdade, a regulação urbanística não é, e nunca foi, obstáculo para a fixação da população de baixa renda em determinadas áreas dos municípios, desde que isto não coloque em risco a criação de territórios exclusivos para a população de alta renda.

ROLNIK (1997) referiu-se à criação, pela regulação urbanística, de uma 'muralha invisível', que transforma o solo em 'mercadoria exclusiva'. BONDUKI (1998) completou este raciocínio afirmando que esta regulação tem sido bastante 'útil' e que de maneira alguma tem-se constituído em 'letra morta' quando se trata de garantir a existência desta muralha.

Portanto, pode-se concluir que para a construção de áreas privilegiadas para a população de alta renda, assim como para a intensificação do lucro imobiliário, a alteração ou desrespeito à legislação urbanística vigente sempre foi a regra.

Para fundamentar esta conclusão foi importante a compreensão da análise formulada em CYTED (2001), ou seja, não é propriamente o aumento do valor imobiliário das áreas exclusivas da população de alta renda o fator precípuo da segregação espacial, muito menos a regulação urbanística é a única razão desta elevação.

Na realidade, a condição macroeconômica basilar de nossa sociedade, apontada em MARICATO (1996), denominada "industrialização com baixos salários", e evidenciada em CYTED (2001), associada à necessidade de criar territórios exclusivos para a alta renda, são as raízes da segregação social e sua expressão no espaço urbano é a segregação espacial por níveis de renda.

É importante lembrar que foi esta condição que garantiu, no Período do Café, entre os finais do século XIX e da década de 20 do século $X X$, um nível de acumulação suficiente para o assentamento das bases da industrialização do sudeste brasileiro. Da mesma maneira, esta condição continuou possibilitando, no final do Período Desenvolvimentista, no início da década de 1980, a permanência da forma de acumulação que DEÁK (1991) denominou "acumulação entravada". Segundo este autor, esse processo de acumulação, nascido na crise dos anos 80 , caracteriza-se pela subordinação da acumulação ao princípio da expatriação dos excedentes, como condição precípua de produção capitalista que assegura a reprodução ampliada da sociedade de elite no Brasil.

Pode-se afirmar ainda que, ao longo do período analisado, a regulação urbanística funcionou parcialmente como instrumento de reforço à construção de territórios desiguais. Mas esse é apenas um fator subsidiário da questão da segregação espacial no Brasil.

VILLAÇA (1998), discutindo distintas concepções sobre a 
questão da segregação no espaço urbano, encontrou nas elaborações teóricas de LOJKINE (1981) e CASTELLS (1979), a chave para o entendimento desta questão. Para LOJKINE a segregação não seria fruto do mecanismo da elevação do solo, o mais provável é que fosse o contrário. Para CASTELLS a distribuição espacial das habitações produz sua diferenciação social e há uma estratificação urbana que corresponde a um determinado sistema de estratificação social. Nas sociedades em que a distância social tem uma forte expressão espacial, ocorre a segregação urbana. Esta concepção enquadra-se perfeitamente à condição social brasileira.

Abordagem análoga a de VILLAÇA conduziu a elaboração deste trabalho, ou seja, a busca do entendimento das particularidades do processo da segregação espacial e da "apropriação diferenciada" do espaço urbano definida por CASTELLS (1979), no que se refere aos municípios centrais da Baixada Santista. Para CASTELLS a questão social tem sua origem entre natureza e cultura, por meio do processo dialético em que o homem transforma-se e transforma seu meio ambiente em sua luta pela vida e pela apropriação diferenciada do produto de seu trabalho.

Acredita-se que o desenvolvimento desta pesquisa trouxe contribuições ao aprofundamento da questão da segregação espacial urbana, em diversos aspectos, ainda que algumas perguntas tenham permanecido sem resposta.

O estudo das conseqüências da implementação da legislação estudada, no sentido de avaliar-se mais claramente em que medida determinados instrumentos legais foram ou não eficazes certamente merece ser aprofundado. Da mesma forma, a análise mais detalhada do vínculo entre moradia e local de trabalho parece ser uma questão a ser desenvolvida.

No entanto, o estudo da relação entre regulação urbanística e valor imobiliário possibilitou uma visão mais clara do processo de produção deste tipo de legislação na Baixada Santista.

Tal contribuição só foi possível a partir dos patamares teóricos elaborados pelos autores e pesquisadores citados, que anteriormente procuraram analisar e questionar as origens encobertas da segregação social nas cidades, em particular nas brasileiras. 
Legislação urbanística e segregação espacial nos municípios centrais da Região Metropolitana da Baixada Santista

\section{Referências bibliográficas}


Legislação urbanística e segregação espacial nos municípios centrais da Região Metropolitana da Baixada Santista 
ANDRADE, Carlos Roberto Monteiro de. O Plano de Saturnino de Brito para Santos, in: Revista Espaço e Debates n 34. São Paulo: NERU, 1991.

ANDRADE, Wilma Therezinha Fernandes de, O Discurso do Progresso: a Evolução Urbana de Santos. 1870 - 1930. Tese de doutoramento São Paulo: FFLCH USP, 1989.

ARANTES, Otília; VAINER, Carlos e MARICATO, Ermínia. A Cidade do Pensamento Único - Desmanchando consensos. Petrópolis: Vozes, 2000.

ARAÚJO FILHO, José Ribeiro. Santos, o porto do café. Rio de Janeiro: IBGE, 1969, apud ANDRADE 1989.

\section{A Expansão Urbana de} Santos, in: A Baixada Santista, Aspectos Geográficos. São Paulo: EDUSP, 1965, vol. 3: 21-48.

ASSECOB, Introdução à Formação Econômica da Baixada Santista. Santos: ASSECOB - Associação dos Empresários da Construção Civil da Baixada Santista, 1984.

BARBOSA, Sinésio C.. O loteamento em São Paulo, in: Revista do Arquivo Municipal 82, 1942, apud BONDUKI, 1998.

BONDUKI, Nabil. Origens da habitação social no Brasil. São Paulo: Estação Liberdade, 1998.

BRITO, Saturnino de, Obras Completas, Saneamento de Santos. Rio de Janeiro: Imprensa Nacional, 1943, vol. II e VII.
CALDATTO, Gino Barbosa. Chalé de Madeira - A moradia popular de Santos, Dissertação de Mestrado, São Paulo: FAU USP, 1998.

CÂMARA MUNICIPAL DE SANTOS. Relatório da Diretoria de Obras e Viação. Santos: CMS, 1919.

CARVALHO, Sonia Nahas de. Planejamento Urbano e Democracia - A experiência de Santos, Tese de Doutorado. Campinas: Instituto de Filosofia e Ciências Humanas da Universidade Estadual de Campinas - UNICAMP, 1999.

CASTELLS, Manuel. La cuestión urbana. Cuidad Del México: Siglo Veintiuno Editores, 1978, apud VILLAÇA, 1998.

CHAUY, Marilena de Souza. O que é ideologia. São Paulo: Editora Brasiliense, 1980.

COHAB Santista. Habitações Coletivas de Aluguel Arrolamento de Imóveis, Relatório de Pesquisa, Santos: COHAB-St, 1996.

CYTED Programa Iberoamericano, Mejor Habitat y Ciudad para Todos. MejorHab, Cyted Programa Iberoamericano de Ciencia y Tecnología para el Desarrollo. São Paulo: Mandarim, 2001.

DEÁK, Csaba. Acumulação entravada no Brasil/ E a crise dos anos 80, in: revista Espaço e Debates, n`32: 32-46. São Paulo, 1991. 
ELETROPAULO. Caminho para o mar in: Memória, ano VI, $\mathrm{n}^{\circ}$ 20: 29-34. São Paulo: Departamento de Patrimônio Histórico da Eletropaulo, 1994.

GAMBETA, Wilson. Desacumular a pobreza: Santos, limiar do século, in: Revista Espaço e Debates, $n^{\circ} 11: 17-27$. São Paulo: NERU, 1984.

GOMES, Roberto Fontes. Crônica entre parentes. São Paulo: Soma, 1984, apud ANDRADE, 1989.

GUIMARÃES, Luís Dias. Na história: uma obra, um alerta à cidade, apud LANNA, 1996.

FARAH, Flávio. Habitações e encostas. Tese de doutoramento. São Paulo: FAU USP, 1998.

FRÚGOLI JR, Heitor. Resenha da obra Imagens de vilas e cidades do Brasil colonial, de REIS FILHO (2001). Jornal da Tarde, Caderno de Sábado, edição de 7 de abril. São Paulo, 2001.

GOLDENSTEIN, Lea. O Assentamento Industrial na Baixada Santista, in: Questões Ambientais Urbanas - Um Seminário Universitário - Anais: 24-29. São Paulo: FAU USP, 1993.

GULLAR, Ferreira. Cidades Inventadas. Rio de Janeiro: José Olympio, 1997.

HOYT, Homer. The pattern of movement of residential rental neighborhoods, in: MAYER, Harold M. e KOHN, Clyde E (eds.). Readings in Urban Geography. Chicago, The
University of Chicago Press: 499-510, 1959, apud VILLAÇA, 1998.

IPT. Relatório n. ⒒599, 1979. São Paulo: IPT - Governo do Estado de São Paulo, 1979.

JUILLET, Alain. Sur la rente fonière urbaine, in: La vie urbaine $\mathrm{n}^{\circ} 4$. Paris, 1971, apud SEABRA, 1979.

LAMBERG, Maurício. O Brasil. Trad. De Luiz Castro. Rio de Janeiro: Lambaerts, 1896, apud ANDRADE (1989).

LANNA, Ana Lúcia Duarte. A cidade controlada: Santos 1870 - 1913. Trabalho apresentado no seminário Origens das Políticas Urbanas Modernas: Europa e América Latina, Empréstimos e Traduções. Rio de Janeiro: IPPUR/UFRJ, Centre de Sociologie Urbaine, ANPUR, 1994.

Uma Cidade na Transição Santos: 1870-1913. São Paulo-Santos: Hucitec-Prefeitura Municipal de Santos, 1996.

LEME, M. Cristina S. Planejamento em São Paulo: 1930 1969. Dissertação de Mestrado. São Paulo: FAU USP, 1982.

LOJKINE, Jean. O Estado Capitalista e a questão urbana. São Paulo: Martins Fontes, 1981.

MAIA, Francisco Prestes. Plano Regional de Santos. São Paulo: 1950., apud NUNES, 1996. 
MARICATO, Ermínia. Metrópole na Periferia do Capitalismo: Ilegalidade, Desigualdade e Violência. São Paulo: Hucitec, 1996.

MARTINS, Fernando Guilherme. Planta genérica de Valores - Município de Santos e Distrito de Bertioga - Dezembro de 1979 - Relatório Final. Santos, 1979.

MARTINS, José de Souza. O cativeiro da terra. São Paulo: Livraria Editora Ciências Humanas, 1979.

MARX, Karl. El Capital - Crítica de la Economia Política. Livro III. México: Fundo de Cultura, 1946, apud SEABRA, 1979.

MEIRELLES, Hely Lopes. Direito Municipal Brasileiro. São Paulo: Malheiros Editores, 2000.

MELLO, Zélia Cardoso de e SACS, Flávio A. M. Características dos Núcleos Urbanos em São Paulo, in: Revista de Estudos Econômicos 15(2), maio/agosto de 1985. São Paulo: IPE, 1985, apud LANNA, 1996.

MORAES, Léo. Cidades-Jardins, in: Revista do Arquivo Municipal 82, São Paulo: 1942, apud BONDUKI, 1998.

NUNES, Luiz Antonio de Paula. De Saturnino de Brito a Prestes Maia na História do Planejamento de Santos. Trabalho apresentado na disciplina "Urbanismo e a cidade moderna - A questão das origens", do curso de mestrado em Estruturas Ambientais Urbanas da FAU USP. São Paulo, FAU USP, 1996.
A formação do urbanismo em Santos 1894 -1951. Dissertação de mestrado. São Paulo: FAU USP, 2001.

REIS FILHO, Nestor G. Aspectos da História da Engenharia Civil em São Paulo 1860-1960. São Paulo: Livraria Kosmos Ed., 1989.

Imagens de vilas e cidades do Brasil colonial. São Paulo: EDUSP/Imprensa Oficial do Estado, 2001.

ROLNIK, Raquel. A Cidade e a Lei - Legislação, política urbana e territórios na cidade de São Paulo. São Paulo: Nobel, 1997.

SANDRONI, Paulo. Novíssimo Dicionário de Economia. São Paulo: Editora Best Seller, 2000.

SANTOS, Francisco Martins dos. História de Santos, in: Poliantéia Santista, $3^{\circ}$ Vol. Santos: Fernando Martins Lichti Ed., 1996.

SAULE Jr., Nelson (coordenador). Direito à Cidade - Trilhas legais para o direito às cidades sustentáveis. São Paulo: Pólis-Editora Max Limonad, 1999.

SEABRA, Odette C. de Lima. A Muralha que Cerca o MarUma Modalidade de Uso do Solo Urbano, Dissertação de Mestrado. São Paulo: FFLCH USP, 1979.

SERRANO, Fábio E. Assentamentos subnormais em Guarujá, Trabalho Programado de Mestrado. São Paulo: FAU USP, 1987. 
Vargem Grande, Guarujá. Um Espaço para a melhoria das condições habitacionais na Baixada Santista, Dissertação de Mestrado. São Paulo: FAU USP, 1991.

SEVCENKO, Nicolau. A revolta da vacina. São Paulo: Brasiliense, 1984, apud LANNA, 1996.

SILVA, Fernando T. da e GITHAY, Maria Lúcia C. O Movimento Operário da Construção Civil Santista. Revista História Social N³. Campinas: IFCH UNICAMP, 1996.

SILVA SOBRINHO, José da Costa. Santos noutros tempos. São Paulo: Revista dos Tribunais, 1953, apud ANDRADE 1989.

SIMONSEN, Roberto. Conferência Inaugural da Jornada de Habitação Econômica, in: Revista do Arquivo Municipal. Ano VII, vol. LXXXII, março-abril. São Paulo: Departamento de Cultura da Sociedade de Etnogravia e Folclore e da Sociedade de Sociologia, 1941.

SIRKIS, Alfredo. O desafio da cidade informal. Jornal Folha de São Paulo, coluna Tendências/Debates, edição de 15 de janeiro de 2002, p. 3. São Paulo, 2002.

TASCHNER, Suzana Pasternak. 1978: Favelas no Município de São Paulo: resultados da pesquisa, in: BLAY, Eva Alterman (org.). A luta pelo espaço. Petrópolis: Editora Vozes, apud SERRANO, 1991.

TORRES, Ricoy e COLONELLI, Consultoria e Projetos S/C Ltda. Coletânea da Legislação Urbanística do Município do Guarujá. Guarujá: 1986.
VEIGA, Evaristo da. Da prophylazia das moléstias infectocontagiosas em São Paulo especialmente do choleramorbus no Estado de São Paulo, Relatório apresentado à Administração Sanitária do Estado, São Paulo: mimeo, 1894, apud BONDUKI, 1998.

VILLAÇA, Flávio. Sistematização crítica da obra escrita pelo professor Flávio Villaça sobre espaço urbano, texto para concurso de Livre-Docente, São Paulo: FAU USP, 1988.

São Paulo: Nobel, 1998.

Espaço intra-urbano no Brasil.

WELCH, Ronald B. A Avaliação de Terrenos Urbanos Uma descrição dos Métodos Empregados no Lançamento das Taxas Imobiliárias. Trad. Eng. L. C. Berrini. São Paulo: Escolas Profissionais Salesianas, 1946. 
Legislação urbanística e segregação espacial nos municípios centrais da Região Metropolitana da Baixada Santista

\section{Anexo 1 - Legislação consultada}


Legislação urbanística e segregação espacial nos municípios centrais da Região Metropolitana da Baixada Santista 
Legislação urbanística e segregação espacial nos municípios centrais da Região Metropolitana da Baixada Santista

Santos

\begin{tabular}{|c|c|c|c|c|}
\hline Tipo & Número & Denominação & Assunto & Data \\
\hline Lei & - & Código de Posturas & & 7 de março de 1847 \\
\hline Lei & - & Código de Posturas & & 24 de abril de 1857 \\
\hline Lei & - & Código de Posturas & & 2 de julho 1897 \\
\hline Lei & 24 & & Limites da cidade & 9 de junho de 1894 \\
\hline Lei & 46 & & Restrição a cortiços & 17 de outubro de 1894 \\
\hline Lei & 58 & & Vilas operárias & 3 de novembro de 1894 \\
\hline Lei & 82 & & Recuos em eixos viários & 12 de agosto de 1896 \\
\hline Lei & 83 & & Eliminação recuos no centro & 17 de setembro de 1896 \\
\hline Lei & 94 & & Expansão da cidade & 15 de março de 1897 \\
\hline Lei & 217 & & Embrião de zoneamento & 11 de abril de 1906 \\
\hline Lei & 235 & & Idem & 10 de outubro de 1906 \\
\hline Lei & 265 & & Isenção de impostos & 5 de junho de 1907 \\
\hline Lei & 322 & & Padronização construções & 28 de agosto de 1908 \\
\hline Lei & 331 & & Recuo lateral & 21 de outubro de 1908 \\
\hline Lei & 341 & & Recuos em eixos viários & 10 de março de 1909 \\
\hline Lei & 374 & & Incentivo a lotemaneto & 5 de abril de 1910 \\
\hline Lei & 444 & & Embrião de zoneamento & 11 de janeiro de 1911 \\
\hline Lei & 460 & & Chalés de madeira & 26 de abril de 1911 \\
\hline Lei & 477 & & $\begin{array}{l}\text { Aumento do número de } \\
\text { pavimentos }\end{array}$ & 11 de outubro de 1910 \\
\hline Lei & 489 & & $\begin{array}{l}\text { Embrião do Código de } \\
\text { Construções }\end{array}$ & 3 de janeiro de 1912 \\
\hline Lei & 501 & & Moradia de operários & 31 de julho de 1912 \\
\hline Lei & 675 & Código de Construções & & 28 de junho de 1922 \\
\hline Lei & 679 & & Revoga suspensão do Código & 9 de outubro de 1922 \\
\hline Lei & 803 & & Perímetros da cidade e chalés & 31 de dezembro de 1926 \\
\hline
\end{tabular}


Legislação urbanística e segregação espacial nos municípios centrais da Região Metropolitana da Baixada Santista

\begin{tabular}{|c|c|c|c|c|}
\hline Lei & 825 & & Legalização de chalés & 26 de novembro de 1927 \\
\hline Lei & 826 & & Alteração de zoneamento & 16 de dezembro de 1927 \\
\hline Lei & 852 & & Aterro de terrenos & 27 de maio de 1929 \\
\hline Decreto-Lei & 254 & & Cria prêmio a estética de edifícios & 2 de março de 1940 \\
\hline Decreto-Lei & 258 & & Perímetros da cidade & 2 de abril de 1940 \\
\hline Decreto-Lei & 306 & & Alteração de zoneamento & 25 de março de 1941 \\
\hline Decreto-Lei & 343 & & Cria Comissão Consultiva & 14 de agosto de 1942 \\
\hline Decreto-Lei & 403 & Código de Obras & & 15 de setembro de 1945 \\
\hline Decreto Executivo & 238 & & Cria Núcleos Comerciais & 18 de junho de 1947 \\
\hline Lei & 940 & & Prazo para Plano de Expansão & 29 de março de 1948 \\
\hline Lei & 942 & & Luz elétrica em chalés & $1^{\circ}$ de abril de 1948 \\
\hline Lei & 977 & & Altera recuos Núcleos Comerciais & 2 de setembro de 1948 \\
\hline Lei & 1.111 & & $\begin{array}{l}\text { Recuos e vagas autos em } \\
\text { edifícios }\end{array}$ & 21 de junho de 1950 \\
\hline Lei & 1.163 & & Altera Lei N ${ }^{0} 1.111$ de 1950 & 12 de dezembro de 1950 \\
\hline Lei & 1.203 & & Chalés de madeira & 16 de maio de 1951 \\
\hline Decreto Executivo & 492 & & Idem & 28 de junho de 1951 \\
\hline Decreto Executivo & 522 & & Idem & 10 de dezembro de 1951 \\
\hline Lei & 1.316 & $\begin{array}{l}\text { Plano Regulador da } \\
\text { Expansão e } \\
\text { Desenvolvimento }\end{array}$ & & 27 de dezembro de 1951 \\
\hline Decreto Executivo & 552 & & Chalés de madeira & 12 de maio de 1952 \\
\hline Lei & 1.746 & & Idem & 19 de setembro de 1955 \\
\hline Lei & 1.811 & & Idem & 7 de janeiro de 1956 \\
\hline Lei & 1.831 & & Alteração do zoneamento & 9 de maio de 1956 \\
\hline Lei & 1.905 & & $\begin{array}{l}\text { Alteração da Lei N }{ }^{0} 1.831 \text {, de } \\
1956\end{array}$ & 7 de dezembro de 1956 \\
\hline Lei & 1.972 & & Perímetro da cidade & 26 de agosto de 1957 \\
\hline Lei & 2.173 & & Alteração uso do solo & 27 de agosto de 1959 \\
\hline
\end{tabular}


Legislação urbanística e segregação espacial nos municípios centrais da Região Metropolitana da Baixada Santista

\begin{tabular}{|c|c|c|c|c|}
\hline Decreto Executivo & 2.087 & & Criação órgão de planejamento & 19 de junho de 1961 \\
\hline Decreto Executivo & 2.128 & & Altera Comissão Consultiva & 28 de setembro de 1961 \\
\hline Decreto Executivo & 2.268 & & Criação órgão de planejamento & 12 de maio de 1962 \\
\hline Decreto Executivo & 2.578 & & Criação de administrações & 10 de dezembro de 1963 \\
\hline Lei & 2.852 & & Criação órgão de planejamento & 27 de abril de 1964 \\
\hline Lei & 2.977 & & Alteração do zoneamento & 24 de setembro de 1964 \\
\hline Lei & 3.064 & & Ampliação Núcleos Comerciais & 30 de dezembro de 1964 \\
\hline Lei & 3.345 & & Alteração do zoneamento & 7 de outubro de 1966 \\
\hline Decreto Executivo & 3.257 & & $\begin{array}{l}\text { Construção de moradias } \\
\text { econômicas }\end{array}$ & 19 de janeiro de 1967 \\
\hline Lei & 3.529 & $\begin{array}{l}\text { Plano Diretor Físico do } \\
\text { Município }\end{array}$ & & 16 de abril de 1968 \\
\hline Lei & 3.530 & Código de Edificações & & 16 de abril de 1968 \\
\hline Lei & 3.531 & Código de Posturas & & 16 de abril de 1968 \\
\hline Lei & 3.533 & $\begin{array}{l}\text { Normas Ordenadoras e } \\
\text { Disciplinadoras da } \\
\text { Urbanização e da } \\
\text { Preservação da Paisagem } \\
\text { Natural dos Morros }\end{array}$ & & 16 de abril de 1968 \\
\hline Lei & 174 & & Alteração do Plano Diretor & 21 de junho de 1986 \\
\hline Lei & 209 & & Idem & 27 de novembro de 1986 \\
\hline Lei Complementar & 53 & $\begin{array}{l}\text { Zonas Especiais de } \\
\text { Interesse Social }\end{array}$ & & 15 de maio de 1992 \\
\hline
\end{tabular}


Legislação urbanística e segregação espacial nos municípios centrais da Região Metropolitana da Baixada Santista

São Vicente

\begin{tabular}{|c|c|l|r|}
\hline Tipo & Número & \multicolumn{1}{|c|}{ Denominação } & \multicolumn{1}{c|}{ Data } \\
\hline Lei & 406 & Código de Obras & $1^{\circ}$ de setembro de 1956 \\
\hline Lei & 2.025 & Uso do Solo da Área Insular & 9 de julho de 1985 \\
\hline Lei & 2.026 & Código de Obras & 9 de julho de 1985 \\
\hline Lei & 2.061 & Uso do Solo da Área Continental & 26 de dezembro de 1985 \\
\hline
\end{tabular}

Cubatão

\begin{tabular}{|l|c|c|c|}
\hline Tipo & Número & \multicolumn{1}{|c|}{ Denominação } & Data \\
\hline Lei & 776 & Uso do Solo & 12 de novembro de 1969 \\
\hline
\end{tabular}

Guarujá

\begin{tabular}{|c|c|l|l|c|}
\hline Tipo & Número & \multicolumn{1}{|c|}{ Denominação } & \multicolumn{1}{c|}{ Assunto } & Data \\
\hline Lei & 319 & Código do Município & & Alteração gabarito edifícios \\
\hline Lei & 854 & & & $1^{\circ}$ de setembro de 1966 de dezembro de 1975 \\
\hline Lei & 1.266 & Plano Diretor Físico & Conjuntos Habitacionais & 8 de novembro de 1976 \\
\hline Lei & 1.313 & & & 30 de abril de 1979 \\
\hline Lei & 1.421 & $\begin{array}{l}\text { Zoneamento de Uso do Solo } \\
\text { e Sistema Viário }\end{array}$ & Urbanização de assentamento & 11 de novembro de 1980 \\
\hline Lei & 1.521 & & & \\
\hline
\end{tabular}


Legislação urbanística e segregação espacial nos municípios centrais da Região Metropolitana da Baixada Santista

Anexo 2 - Cartografia consultada 
Legislação urbanística e segregação espacial nos municípios centrais da Região Metropolitana da Baixada Santista 
Os mapas, cujas reproduções apresentamos a seguir, complementaram os já apresentados ao longo do trabalho, na formação da base cartográfica necessária para a elaboração da planta de evolução da ocupação da área insular de Santos (ver Figura 7).

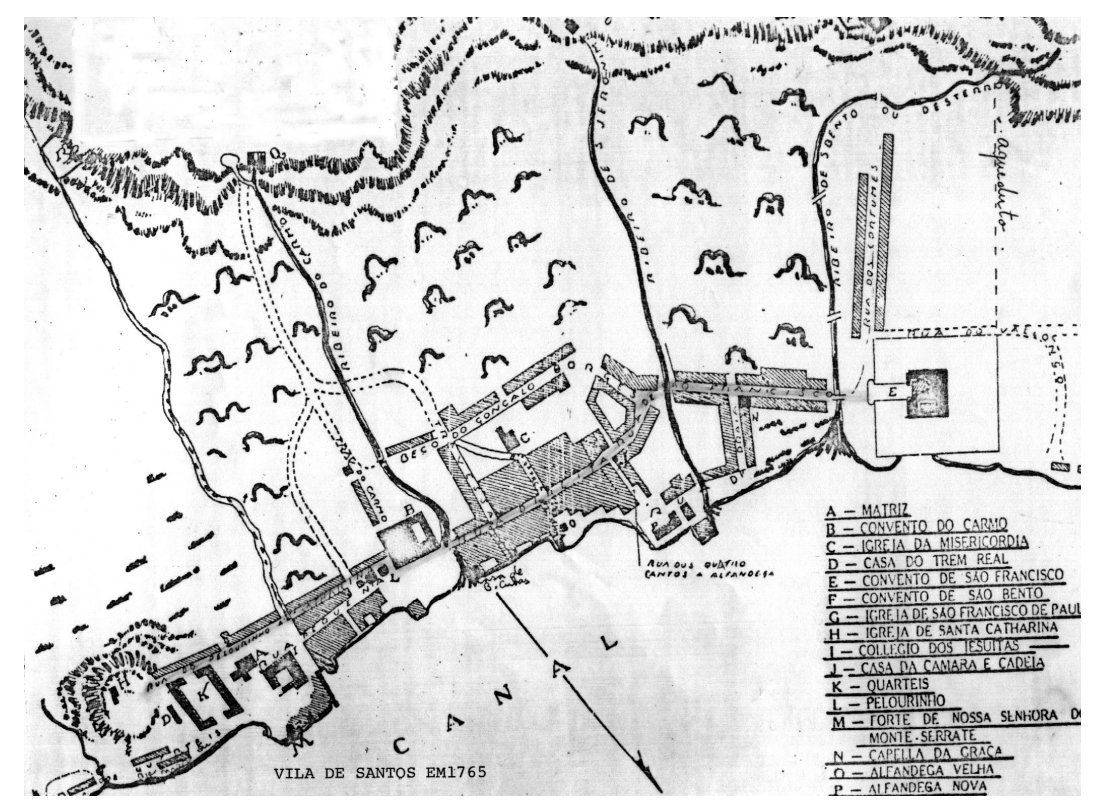

Carta 1 - Plano da Vila de Santos em 1765. Autor: Benedito Calixto. Fonte: SOUZA, Alberto. Os Andradas, $1^{\circ}$ Vol. São Paulo: Tipografia Piratininga (1922:150/151), apud ANDRADE (1989).

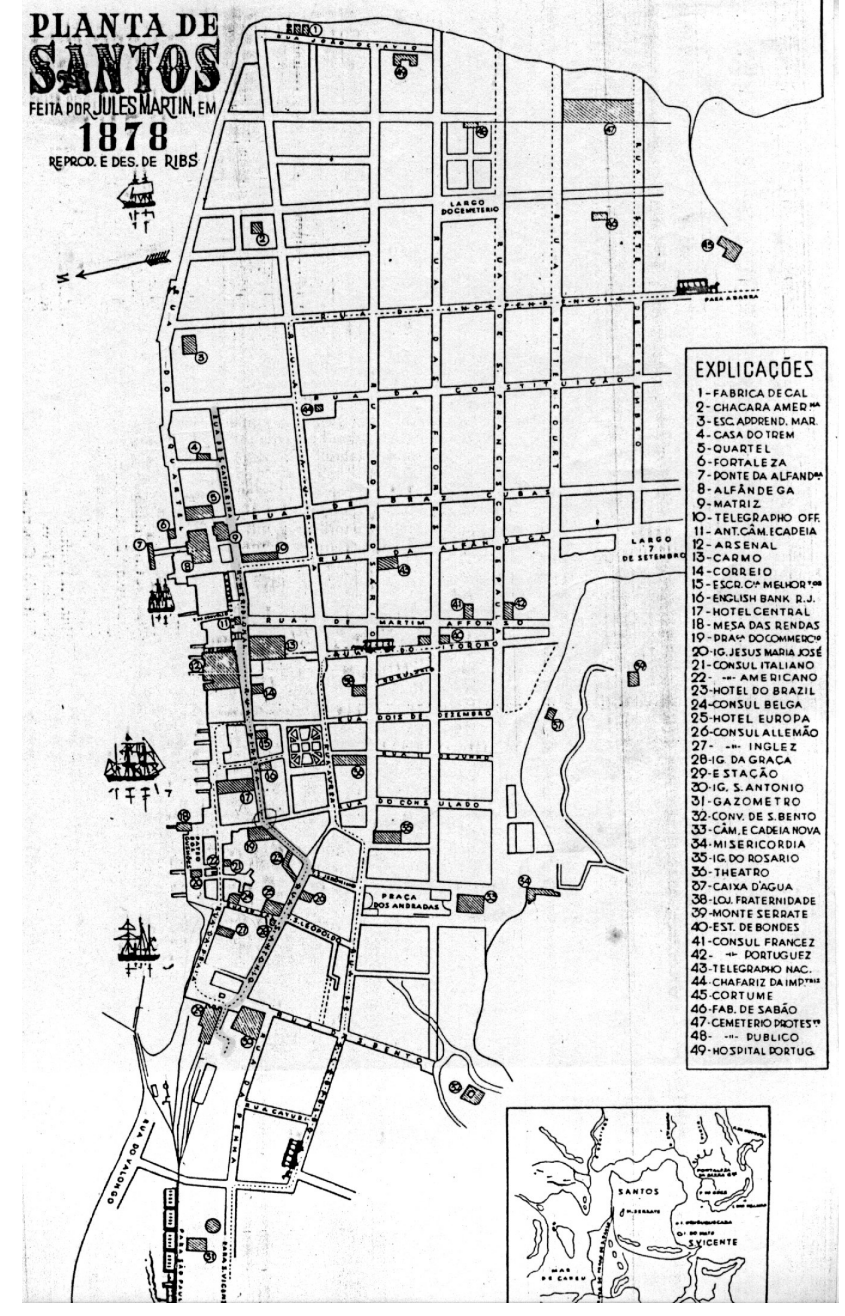

Carta 2 - Plano da Vila de Santos em 1878. Autor: Jules Martin. Fonte: ANDRADE (1989) e LANNA (1996). 
Legislação urbanística e segregação espacial nos municípios centrais da Região Metropolitana da Baixada Santista

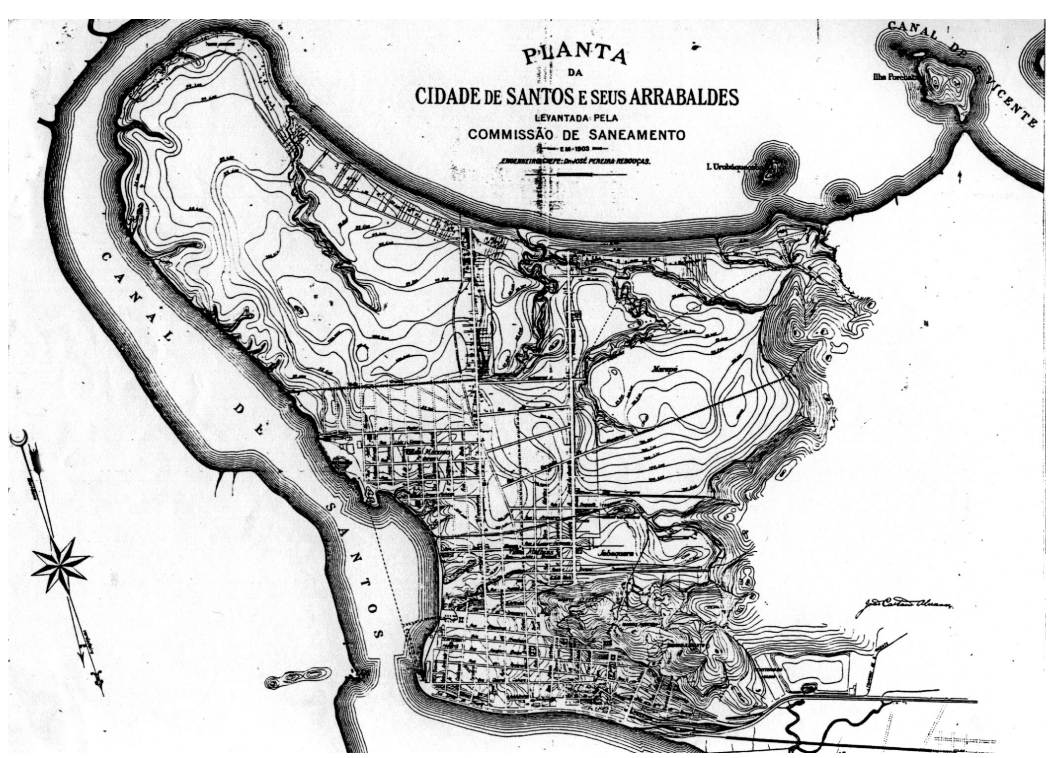

Carta 3 - Plano de Santos em 1903. Autor: José Pereira Rebouças. Fonte: ANDRADE (1989).

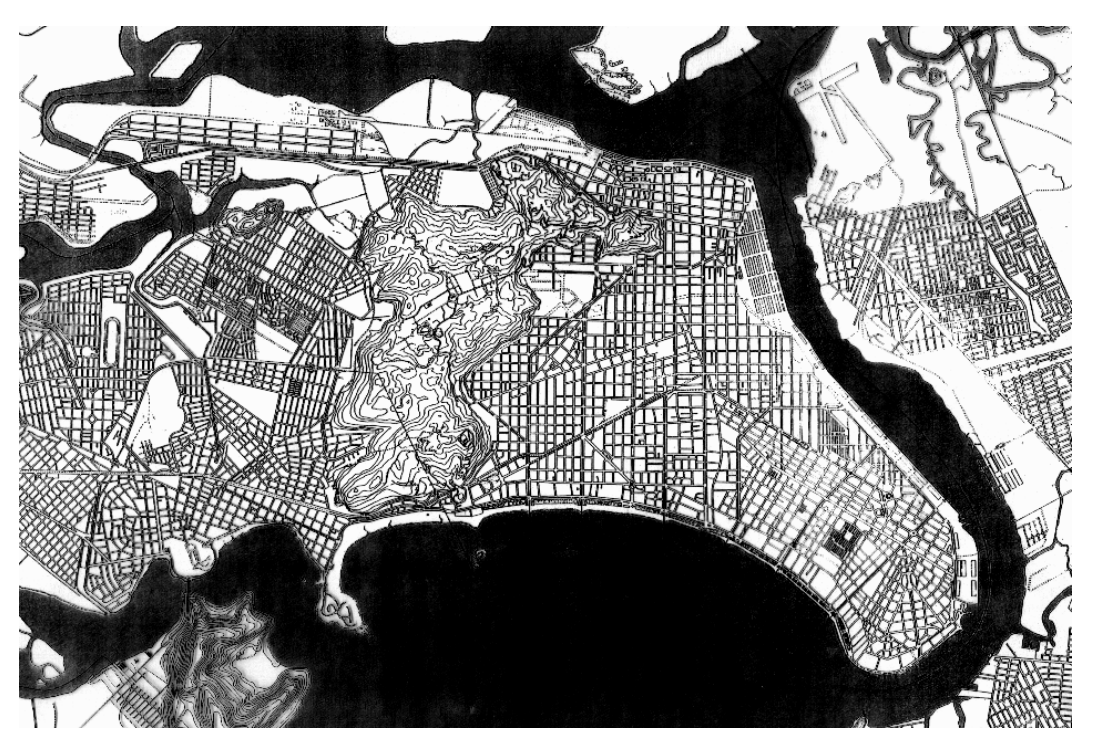

Carta 4 - Plano de Santos. Fonte: Plano Diretor Físico do Município, Lei 3.529, de 1968. Prefeitura Municipal de Santos. 
Legislação urbanística e segregação espacial nos municípios centrais da Região Metropolitana da Baixada Santista

\section{Anexo 3 - Entrevistas realizadas}


Legislação urbanística e segregação espacial nos municípios centrais da Região Metropolitana da Baixada Santista 
1. Augusto Muniz Campos, arquiteto do departamento de Planejamento da Prefeitura de Cubatão e professor da Faculdade de Arquitetura e Urbanismo da Universidade Católica de Santos.

2. Carlos Alberto Soares de Souza, engenheiro da Empresa Municipal de Urbanização do Guarujá EMURG.

3. Cassandra Maroni Nunes, geóloga $e$ administradora dos morros de Santos, entre 1989 e 1996.

4. Enzo Benvenuto Gambini, arquiteto e ex-chefe da Divisão de Obras Particulares da Prefeitura de Santos.

5. Fábio Eduardo Serrano, arquiteto e professor da Faculdade de Arquitetura e Urbanismo da Universidade Católica de Santos.

6. Luiz Fernando de Almeida, professor da Faculdade de Arquitetura e Urbanismo da Universidade Católica de Santos.

7. Marco Antônio Vilella dos Santos, Diretor de Meio Ambiente da Prefeitura de São Vicente. 